\title{
Site U1326
}

\author{
Expedition 311 Scientists $^{2}$
}

\section{Chapter contents}

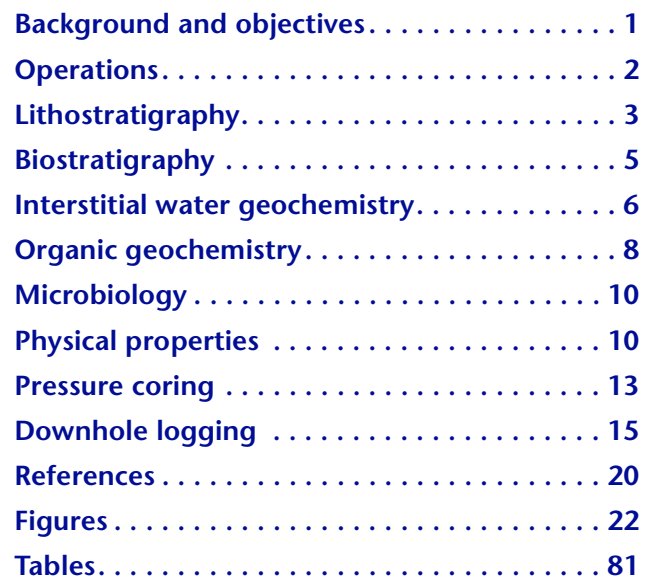

${ }^{1}$ Expedition 311 Scientists, 2006. Site U1326. In Riedel, M., Collett, T.S., Malone, M.J., and the Expedition 311 Scientists. Proc. IODP, 311: Washington, DC (Integrated Ocean Drilling Program Management International, Inc.). doi:10.2204/iodp.proc.311.104.2006 'Expedition 311 Scientists' addresses.

\section{Background and objectives}

Site U1326 (proposed Site CAS-03C; Collett et al., 2005) is located on top of the first uplifted ridge of accreted sediments along the margin-perpendicular transect established during Integrated Ocean Drilling Program (IODP) Expedition 311 (Fig. F3 in the "Expedition 311 summary" chapter). The newly acquired bathymetry data from the University of Washington show a collapse structure near the originally proposed Site CAS-03B (Collett, Riedel, Malone, et al., 2005) that was previously unrecognized (Fig. F5 in the "Expedition 311 summary" chapter). A map with the site survey seismic data acquired in the area is shown in Figure F1. We switched former alternate Site CAS-03C to the primary site to avoid coring into the slump feature because it may locally complicate the history of deposition, fluid flux, and related gas hydrate formation.

The head wall of the slump feature is $\sim 250 \mathrm{~m}$ high and the slump has eroded a $\sim 2.5 \mathrm{~km}$ long section into the ridge. Slump material can be identified in the bathymetry data and previously in SeaMARCII acoustic imagery (Davis et al., 1987). Because of the steep slope, it is difficult to seismically image the deposit. A striking characteristic of the ridge is the occurrence of several linear features crossing the ridge in an east-west direction (Fig. F5 in the "Expedition 311 summary" chapter). These linear features are clearly associated with faults as seen in Figure F2. The faults outcrop at the seafloor and generate a seafloor displacement of as much as $25 \mathrm{~m}$. These faults can be seismically traced from the surface down through the sedimentary section to depths below the bottom-simulating reflector (BSR). The occurrence of the faults is limited to the location of the slump scar, and the ridge heals to either end at the southeast and northwest limits, where the sediments are not faulted but appear seafloor parallel. Overall, the seismic character of the ridge changes from the southwest to the northeast across the ridge, with the southwest-facing part of the ridge characterized by strong, semicontinuous reflectivity (Figs. F3, F4), whereas the seismic reflectivity disappears underneath the northeast-facing flank of the ridge (Fig. F5). The slopes on the flanks of the ridge are relatively steep, making seismic imaging challenging, but the ridge is generally symmetrical so the differences in the seismic character of the ridge cannot be explained by simple variable acquisition parameters. It is possible that the internal deformation of the sediments may increase toward the northwest-facing flank and results in a loss of seismic coherency similar to that observed in accreted sediments along this margin. 
A BSR is present underneath most of the ridge, especially seen in the lower frequency seismic data (Fig. F3). However, the multichannel seismic data along Line PGC9902_CAS03a show that the BSR is practically absent underneath the slump feature where the most heavily faulted sediments occur. As a result of the complicated nature of the seafloor, imaging capabilities may be limited especially in the high-frequency data (see Fig. F4 in the "Site U1328" chapter).

The coring and logging objectives at this site were tied to completing the transect of scientific drill sites across the northern Cascadia margin near Vancouver Island. Site U1326 is the closet location to the deformation front and probably represents the tectonically youngest occurrence of gas hydrate on the northern Cascadia margin.

At this western end-member site of gas hydrate evolution in the accretionary prism, the objectives include

- Studying the distribution of gas hydrate,

- Defining the nature of the BSR,

- Developing baseline geochemical and microbiological profiles, and

- Obtaining data needed to ground-truth remotely acquired imaging techniques such as seismic or controlled-source electromagnetic (CSEM) surveys.

The operational plan to achieve these objectives was based on a general three-hole concept, which includes

- A logging-while-drilling/measurement-while-drilling (LWD/MWD) hole;

- A continuously cored hole to characterize geochemical and microbiological baselines and proxies for gas hydrate;

- An additional "tools" hole for specialized pressure coring systems, including the IODP Pressure Core Sampler (PCS) and the HYACINTH Fugro Pressure Corer (FPC) and HYACE Rotary Corer (HRC) systems, combined with selected spot-coring using the conventional extended core barrel (XCB) system; and

- A wireline logging program in the tools hole using the triple combination and Formation MicroScanner-sonic tool strings.

\section{Operations}

\section{Hole U1326A}

After transiting in dynamic positioning (DP) mode from Hole U1325A and downloading the data from the LWD/MWD tools, the LWD/MWD bottom-hole assembly (BHA) was tripped to the seafloor. Hole U1326A (proposed Site CAS-03C; Collett et al., 2005) was spudded at $1445 \mathrm{~h}$ on 22 September 2005 at an estimated seafloor depth of 1828.1 meters below sea level (mbsl; 1839.0 meters below rig floor [mbrf]). To avoid blowing out the top of the hole, we changed the spud-in parameters to 100 gallons per minute (gpm) circulation with $10-15 \mathrm{rpm}$ rotation. At 10 meters below seafloor (mbsf), top drive rotation was increased to $40 \mathrm{rpm}$. At $29 \mathrm{mbsf}$, parameters were increased to maintain a $50 \mathrm{~m} / \mathrm{h}$ rate of penetration (ROP) with a minimum circulation of $270 \mathrm{gpm}$. The LWD/MWD safety protocol was followed without incident and required no corrective action (see "Downhole logging" in the "Methods" chapter). The hole was drilled to a total depth (TD) of 300 mbsf. After displacing the hole with 10.5 ppg sepiolite mud, the drill string was pulled clear of the seafloor at $0600 \mathrm{~h}$ on 23 September, ending operations in Hole U1326A. The pipe was pulled to a safe distance above the seafloor in preparation for the DP transit to Site U1327.

\section{Hole U1326B}

After completing Hole U1325D, we pulled the drill pipe back to $\sim 1600$ mbrf and transited $\sim 2.8 \mathrm{nmi}$ in DP mode to Site U1326. We spudded Hole U1326B at $1205 \mathrm{~h}$ on 23 October 2005, but the core contained only $1.55 \mathrm{~m}$ of sediment, which was not ideal for the planned shallow microbiological and geochemical studies. Based on recovery in Core $1 \mathrm{H}$, the estimated seafloor depth is 1828.4 mbsl (1840.0 mbrf).

\section{Hole U1326C}

The bit was set at 1834 mbrf ( $2 \mathrm{~m}$ lower than in Hole U1326B), and without offsetting, Hole U1326C was spudded at $1245 \mathrm{~h}$ on 23 October 2005 . The first core recovered $3.93 \mathrm{~m}$ of sediment, indicating a seafloor depth of $1828.0 \mathrm{mbsl}$ (1839.6 mbrf). On the fourth advanced piston corer (APC) run ( $30 \mathrm{mbsf})$, we unexpectedly hit APC refusal and switched to XCB coring. XCB coring advanced the hole to a depth of 82.7 mbsf, which was followed by three consecutive pressure core deployments within a high electrical resistivity zone identified on LWD/MWD downhole logs. The first pressure core system deployed was the FPC, which recovered a partial core $(15 \mathrm{~cm})$ at less than full pressure (see "Pressure coring"). The second system to be deployed was the PCS, which recovered a partial core under pressure. The third pressure core system deployed was the HRC, which was damaged at the bottom of the hole because of excessive ship heave $(>4 \mathrm{~m})$ and packing of formation sands around the outer barrel. The HRC cutting shoe and a spacer 
section came unscrewed and were left in the hole, which resulted in the termination of Hole U1326C at a TD of 86.7 mbsf.

\section{Hole U1326D}

After tripping the BHA back to the seafloor, the ship was moved $30 \mathrm{~m}$ southwest (15 m southwest of Hole U1326A) (Fig. F6). Hole U1326D was spudded at $1130 \mathrm{~h}$ on 24 October 2005 and drilled to a depth of $78.8 \mathrm{mbsf}$ in preparation for continued coring operations. Because of problems associated with heave, which worsened throughout the day, we decided to suspend all pressure coring operations for the remainder of the expedition to avoid the possibility of damaging the tools and losing the last hole with little operational time remaining. XCB coring deepened the hole to $271.4 \mathrm{mbsf}$ with an average recovery of $63.3 \%$ (Table T1). With forecasts of deteriorating weather conditions on the morning of 26 October, it was decided to stop coring at a depth of $271.4 \mathrm{mbsf}$ and deepen the hole to a TD of 300 mbsf by drilling, which allowed us to gain time and complete logging, rigging down, and securing the rig floor before the expected arrival of the forecasted storm. Despite the marginal conditions, we did attempt three deployments with the Davis-Villinger Temperature Probe (DVTP) at 252.2, 271.4, and 300 mbsf, which yielded marginally useful data.

After completing coring operations, the hole was prepared for logging with a wiper trip followed by displacing the hole with weighted mud. We decided to conduct a single downhole logging run with a nonstandard IODP tool string, which included the Scintillation Gamma Ray Tool (SGT), Phasor Dual Induction Tool (DIT), and the Dipole Sonic Imager (DSI). At $2315 \mathrm{~h}$ on 26 October, the tool string was deployed in the hole and lowered to $298.4 \mathrm{mbsf}$. Two successful passes were made from this depth and the tool was back on deck at $0345 \mathrm{~h}$. The drill string was pulled clear of the seafloor at $0530 \mathrm{~h}$ on 27 October, ending operations in Hole U1326D.

\section{Transit to Victoria, British Columbia}

After tripping the drill string to the rig floor, recovering two beacons, and securing the ship for transit, we departed under deteriorating sea states (with 40$45 \mathrm{kt}$ sustained winds gusting to $>50 \mathrm{kt}$ ) at $1320 \mathrm{~h}$ on 27 October 2005. We made the short $157 \mathrm{nmi}$ transit to Victoria in $22 \mathrm{~h}$ at an average speed of $7.1 \mathrm{kt}$. Expedition 311 officially concluded with the first line ashore at $1225 \mathrm{~h}$ on 28 October.

\section{Lithostratigraphy}

Site U1326 is located at the far western downslope end of the Expedition 311 transect, on the first up- lifted ridge of accreted sediments. Three of the four holes (Holes U1326A-U1326D) at this site were cored; Hole U1326B was cored to $1.5 \mathrm{mbsf}$ ( $1.5 \mathrm{~m}$ cored), Hole U1326C to $86.7 \mathrm{mbsf}$ ( $85.7 \mathrm{~m}$ cored), and Hole U1326D to 300 mbsf (192.6 m cored). Recovery was excellent in Hole U1326B (103.3\%) but limited in Holes U1326C (63.5\%) and U1326D (63.3\%).

We divided the $271.4 \mathrm{~m}$ thick sedimentary section recovered from Holes U1326C and U1326D into three lithostratigraphic units (Fig. F7) based on visual inspection of the cores and analysis of smear slides. Other parameters, such as mineralogy data from X-ray diffraction (XRD) analyses, helped to better define the entire stratigraphic section. The results were also compared and correlated with seismic data, downhole LWD/MWD data, and physical property measurements.

\section{Lithostratigraphic units}

\section{Lithostratigraphic Unit I}

Intervals: Sections 311-U1326B-1H-1 through 1H$\mathrm{CC}$ and 311-U1326C-1H-1 through $4 \mathrm{H}-1$

Depths: Hole U1326B: 0.00-1.55 mbsf and Hole U1326C: 0.00-24.13 mbsf

Age: Holocene-Pleistocene ( $<0.3 \mathrm{Ma})$

Unit I is mainly composed of dark gray (N4) and dark greenish gray (5GY 4/1) silty clay and clay, and clay with diatoms (Fig. F8). Gradual color changes from dark gray to dark greenish gray are observed especially in Core 311-U1326C-3H (Fig. F8). Minor lithologies are silty clay with foraminifers, dark gray foraminifer sand, dark gray silt, silty sand, and sand layers or lenses (Fig. F9). The silt and sand layers in Sections 311-U1326C-2H-2, 2H-5 through 2H-7, 3H$1,3 \mathrm{H}-3,3 \mathrm{H}-4$, and $4 \mathrm{H}-1$ are all tilted in the same direction. The single layers show varying thickness from a few millimeters to $\sim 10 \mathrm{~cm}$. In Section 311U1326C-2H-2, layers show coarsening-upward sequences. The major nonbiogenic components of Unit I are clay minerals, quartz, feldspar, opaque minerals, accessory minerals, biotite, and some rock fragments. Rare to moderate sulfide mottling, appearing as dark gray (N4) stains, occurs in Sections 311-U1326C-1H-2, 2H-2, 2H-4, 2H-5, 3H-1, and 3H3 through $3 \mathrm{H}-6$. Small sulfide concretions $(<2 \mathrm{~mm})$ are present in Sections 311-U1326C-1H-2, 2H-5, and $2 \mathrm{H}-6$.

The major biogenic components of Unit I are diatoms (as much as 10\% in Sample 311-U1326C-3H-6, $90 \mathrm{~cm}$ ). Foraminifers occur as well and are especially abundant (35\%) in Sample 311-U1326C-1H-2, 40 $\mathrm{cm}$. Visibly observed foraminifers occur in Section 311-U1326C-1H-CC. Bivalve shell fragments are ob- 
served in Sections 311-U1326C-1H-2 (Fig. F10) and $3 \mathrm{H}-5$, and sponge spicules are seen in Sections 311U1326C-3H-4 and 3H-5.

Some small sedimentary structures related to softsediment deformation are observed in Section 311U1326C-2H-5. Greenish patches, rich in glauconite, are present in intervals 311-U1326C-1H-2, 30-65 $\mathrm{cm}$; $2 \mathrm{H}-4,15-65 \mathrm{~cm}$; and $2 \mathrm{H}-5,0-10 \mathrm{~cm}$. Unlithified carbonate cement, as well as partly lithified carbonate, is observed in intervals 311-U1326B-1H-1, 95$102 \mathrm{~cm}$ (nonstoichiometric dolomite; $46 \mathrm{~mol} \%$ $\mathrm{MgCO}_{3}$ ) (Fig. F11); 1H-1, 149-150 cm (Fig. F12); and $1 \mathrm{H}-2,62-64 \mathrm{~cm}$. Some small concretions (millimeter scale) are present in Section 311-U1326C-3H-1. The Unit I/II boundary is marked by the disappearance of diatoms and calcareous fossils and an increase in silty and sandy layers in the minor lithology.

\section{Lithostratigraphic Unit II}

Intervals: Sections 311-U1326C-4H-1 through 10X-CC and 311-U1326D-2X-1 through 7X$\mathrm{CC}$

Depths: Hole U1326C: 24.13-82.70 mbsf and Hole U1326D: 88.40-146.30

Age: Pleistocene (>0.3 Ma)

Unit II is composed of dark gray (N4) clay and silty clay and dark olive-gray (5Y 3/2) clay locally interbedded with dark gray (N4) silt, silty sand, and sand layers (Fig. F13). In the lower part of Unit II, some sand patches occur within clay or silty clay (Fig. F14). Some silty or sandy layers show fining-upward sequences in Sections 311-U1326C-6X-4, 7X-2, 9X-2, 311-U1326D-2X-4, and 7X-3. Parallel laminations are present in Sections 311-U1326C-6X-5 and 311U1326D-3X-5. Silt laminae are observed in Sections 311-U1326D-9X-4 and 10X-1.

The major nonbiogenic components of Unit II are clay minerals, quartz, feldspar, accessory minerals (mainly amphibole), opaque minerals, and biotite. Rare sulfide mottling is observed in the upper (Sections 311-U1326C-5X-1 and 5X-3) and lower (Sections 311-U1326D-5X-1, 5X-4, 6X-3, 6X-CC, and 7X3 ) part of this unit. Sulfide concretions are present in Sections 311-U1326D-5X-1 and 5X-2. Dropstones $(<1.5 \mathrm{~cm})$ are found in the lower part of Unit II (Sections 311-U1326D-4X-4, 4X-5, 5X-4, and 6X-3) (Fig. F14). Unlithified carbonate cements are present in Sections 311-U1326C-6X-1, 8X-CC, and 311U1326D-5X-2 (Fig. F15). A lithified carbonate is found in Section 311-U1326C-9X-2.

Biogenic components are almost absent in Unit II. There are no diatoms. Foraminifers, nannofossils, and organic fragments are rarely present on the basis of smear slide observations. Pieces of brownish wood fragments are observed in Section 311-U1326D-5X5 .

Soft-sediment deformation is observed over an interval of two cores in the upper part of Unit II (Cores 311-1326C-5X through 6X) (Fig. F16). A fault displacing silty layers in a normal sense is present at the bottom part of the zone of soft sediment deformation (interval 311-1326C-6X-5, 24-26 cm) (Fig. F17).

In Unit II, we observed soupy and mousselike textures. Soupy textures are present in Sections 311U1326C-7X-3 and 8X-1. Mousselike textures are observed in Sections 311-U1326C-7X-3 and 311U1326D-2X-1, 2X-4, 3X-1, and 7X-1. The Unit II/III boundary is marked by the appearance of diatoms (see "Biostratigraphy"), although their abundance is low and at the beginning of coring-related biscuiting.

\section{Lithostratigraphic Unit III}

Interval: Sections 311-U1326D-8X-1 through 20XCC

Depth: 146.30-271.40 mbsf

Age: Pleistocene (>0.3 Ma)

Unit III is mainly composed of dark greenish gray (5GY 4/1) and dark gray (N4) clay, clay with diatoms, silty clay, and silty clay with diatoms. Coarser grained dark gray (N4) and very dark gray (N3) clayey silt, sandy silt, silt, sand-silt-clay, silty sand, and sand occur as minor lithologies in Unit III (Fig. F17). Fining-upward sequences are observed in Sections 311-U1326D-10X-3 and 20X-5. Drilling biscuits and other coring-related disturbance features are present throughout most of the unit.

The major nonbiogenic components of Unit III are clay minerals, quartz, feldspar, accessory minerals, opaque minerals, and biotite. Rare to moderate sulfide mottles are only present in the upper part of Unit III in Sections 311-U1326D-8X-3, 9X-2, 11X-2, $11 \mathrm{X}-4$, and 20X-7. Small $(<5 \mathrm{~mm})$ concretions are present in Sections 311-U1326D-11X-5 and 12X-1. A dark, round, volcanic rock fragment $(1.5 \mathrm{~cm} \times 2 \mathrm{~cm})$ is observed in Section 311-U1326D-17X-1, and an olive colored rock fragment $(1 \mathrm{~cm} \times 1.5 \mathrm{~cm})$ is seen in Section 311-U1326D-20X-5.

The biogenic components differ from Unit II. The major lithology contains some fossils, diatoms, foraminifers, siliceous spicules, and organic debris. The most important fossils are diatoms (as much as 37\% in Sample 311-1326D-20X-5, $87 \mathrm{~cm}$ ).

Angular, partly lithified carbonates occur in intervals 311-U1326D-9X-1, 0-2 cm, $16 \mathrm{~cm}, 18-19 \mathrm{~cm}, 25 \mathrm{~cm}$ (Fig. F18), and $46-47 \mathrm{~cm}$. XRD analysis confirms a combination of high-Mg calcite $\left(8 \mathrm{~mol} \% \mathrm{MgCO}_{3}\right)$ and nonstoichiometric dolomite (34 $\left.\mathrm{mol} \% \mathrm{MgCO}_{3}\right)$. 
Unlithified carbonate cements are present in Sections 311-U1326-12X-5, 12X-CC, and 20X-3. A lithified carbonate nodule is present in Section 311U1326D-16X-1.

Soupy sediment textures related to the presence of gas hydrate are present in Sections 311-U1326D$11 \mathrm{X}-2,13 \mathrm{X}-1$, and 17X-1. Mousselike sediment textures are present in Sections 311-U1326D-10X-1, $11 \mathrm{X}-2,11 \mathrm{X}-4,13 \mathrm{X}-1,14 \mathrm{X}-1,14 \mathrm{X}-3,16 \mathrm{X}-1,16 \mathrm{X}-3$, 16X-4, 17X-1, 17X-5, 18X-2, and 18X-4 (Figs. F19, F20).

\section{Environment of deposition}

Site U1326 recovered a sequence that corresponds to slope basin sediments (see "Background and objectives").

Lithostratigraphic Unit III is characterized by finegrained (clay to silty clay) detrital sediments with few, thin silty/sandy interlayers from turbidites. Generally abundant, mostly marine diatoms (see "Biostratigraphy") occur throughout this unit. We interpret this interval as mixed hemipelagic-turbiditic deposition. The presence of authigenic carbonate cement shows that diagenetic processes are active in Unit III.

Lithostratigraphic Unit II is characterized by finegrained (clay to silty clay) detrital sediments with intervals of frequent silty/sandy interlayers. We interpret the coarser interlayers as turbiditic deposits, the frequent occurrence of which might indicate times of active tectonism. Below $30.4 \mathrm{mbsf}$, abundant softsediment deformation and dipping strata (also inferred from logging results; see evidence of layers dipping to the northeast in "Downhole logging") show that tectonism is more active at this westernmost end of the transect drilled during Expedition 311 . The presence of unlithified authigenic carbonate cement and a lithified carbonate shows that diagenetic processes are active in Unit II (see also "Interstitial water geochemistry").

Lithostratigraphic Unit I is characterized by finegrained (clay to silty clay) detrital sediments with thin silty/sandy interlayers from turbidites. Soft-sediment deformation observed in Section 311-U1326C$2 \mathrm{H}-5$ ( $10 \mathrm{mbsf})$ may be potentially related to a slump (see also "Interstitial water geochemistry"). Foraminifers, bivalve shell fragments, sponge spicule remains, mottling, and bioturbation, together with the high marine/nonmarine ratio of diatoms suggest hemipelagic sedimentation mixed with turbiditic inputs (coarse-grained facies). The presence of unlithified carbonate cement shows that diagenetic processes are active in Unit I.

\section{Biostratigraphy}

Cores were recovered from Holes U1326B, U1326C, and U1326D. Sample 311-U1326B-1H-CC, the only sample obtained from Hole U1326B, was barren of diatoms. Holes U1326C and U1326D contain a $\sim 270$ $\mathrm{m}$ thick Quaternary sedimentary sequence. The biostratigraphy determined for Site U1326 was based on an examination of all core catcher samples from the three cored holes (Table T2).

\section{Diatoms}

Diatoms are generally very rare to barren and poorly preserved in most of the samples from Site U1326. Only a few samples contain common to abundant and poorly to moderately preserved diatoms. Samples 311-U1326C-2H-CC (13.62 mbsf) and 3H-CC (22.13 mbsf) contain common to abundant diatom assemblages dominated by Stephanopyxis spp. and Thalassionema nitzschioides and are accompanied by rare occurrences of Neodenticula seminae. A large number of resting spores of Chaetoceros were observed in Sample 311-U1326C-3H-CC. Samples 311U1326C-4H-CC through 10X-CC and 311-U1326D$2 \mathrm{X}$-CC through 7X-CC have rare diatoms or are barren. Common to rare diatoms from Samples 311U1326D-8X-CC through 10X-CC (150.50-172.87 mbsf) and 19X-CC (254.44 mbsf) are characterized by dominant occurrences of Stephanopyxis spp. and $T$. nitzschioides and rare occurrences of $N$. seminae and Proboscia curvirostris. Samples 311-U1326D-8XCC and 9X-CC (150.50-160.00 mbsf) are also characterized by rare occurrences of Thalassiosira jouseae and abundant occurrences of resting spores of Chaetoceros. All samples with common to abundant diatoms are dominated by marine diatoms (>90\%), but some samples with rare diatoms (Samples 311U1326C-1H-CC and 5H-CC and 311-U1326D-13XCC) are dominated by nonmarine diatoms.

The interval between the shallowest sample and Sample 311-U1326C-3H-CC (3.88-22.13 mbsf) contains $N$. seminae but lacks $P$. curvirostris and is assigned to North Pacific Diatom (NPD) Zone 12 ( $N$. seminae Zone; 0-0.3 Ma). A diatom zonal assignment is not possible for the interval between Samples 311U1326C-4H-CC and 10X-CC or from 311-U1326D2X-CC through 7X-CC (28.27-141.65 mbsf) because these intervals contain no diatoms or zonal marker species. The last occurrence (LO) of $P$. curvirostris was recognized in Sample 311-U1326D-8X-CC (150.50 mbsf), marking the NPD Zone $12 / 11$ boundary ( $P$. curvirostris Zone). The interval between the LO of $P$. curvirostris and Sample 311-U1326D-19X-CC (150.50-254.44 mbsf) contains $P$. curvirostris but 
lacks Actinocyclus oculatus and was assigned to NPD Zone 11 (P. curvirostris Zone; 0.3-1.0 Ma). Sample 311-U1326D-20X-CC (270.69 mbsf) cannot be assigned to a diatom zone because it is barren. The NPD Zone 12/11 boundary is likely within the above mentioned barren interval (28.27-141.65 mbsf), but its exact depth determination requires postcruise analysis of additional samples at more closely spaced intervals.

\section{Interstitial water geochemistry}

The main objectives at this site were to document the evolution of the interstitial water (IW) chemistry and the distribution of gas hydrate at the westernmost uplifted ridge of the Cascadia accretionary prism.

A total of 75 IW samples were processed from two holes cored at Site U1326. In Hole U1326C, 27 whole-round samples, $10-40 \mathrm{~cm}$ in length, were retrieved at the catwalk. The sampling frequency was two per section in the uppermost $10 \mathrm{~m}$ (Sections 311-U1326C-1H-1 through 2H-4), followed by one to three samples per core to TD of the hole. The sediment collected from Core 311-U1326C-5X, the first $\mathrm{XCB}$ core, was too disturbed and unsuitable for IW extraction. Two samples contained gas hydrate (Samples 311-U1326C-6X, 83-96 cm, and 7X-3, 74-101 $\mathrm{cm})$. Based on lithology, infrared (IR) camera images, and visual core observations, these samples were split into five subsamples, thus three extra samples were processed. In addition, two samples from pressure Core 311-U1326C-12P were collected, generating a total of 30 IW samples from this hole.

In Hole U1326D, 37 IW samples were collected at a sampling frequency of one to two per core depending on recovery. Most whole-round IW samples were $10-50 \mathrm{~cm}$ in length, except for the deepest cores, from which we collected $100 \mathrm{~cm}$ long samples in an effort to obtain sufficient volumes of interstitial fluid. Because of the weather conditions and severe ship heave, the recovered sediment was highly disturbed and only a few clean sediment "biscuits" were retrieved from these long whole-round samples. Six of the samples were divided based on IR imaging and lithology (as described below), yielding eight additional samples for processing for a total of 45 IW samples from this hole.

In an effort to characterize the IW chemistry associated with gas hydrate-bearing sediment and to compare it with sediment with an IW composition more typical of background conditions, whole-round samples were chosen from intervals with the highest IR temperature anomalies and from zones with less anomalous thermal signals within the zone of gas hydrate occurrence. Three samples from Hole U1326C and eight samples from Hole U1326D were collected to evaluate the chlorinity of the IW associated with intervals where gas hydrate presence was inferred from IR anomalies. These samples were imaged again with a handheld IR camera, photographed, and described prior to the squeezing process, documenting the association of gas hydrate mostly with sand horizons, as previously observed at Sites U1325 and U1328. Sand and clay lithologies were split and squeezed separately.

The IW data collected at Site U1326 are listed in Table T3. Because of the lithified nature of the formation, XCB coring was used for the collection of a large portion of IW samples. Because XCB coring yields relatively more disturbed cores, these cores are more likely to be contaminated with the drilling fluid than APC cores. Sulfate concentration below the depth of the sulfate/methane interface (SMI) was used to identify and quantify contamination by the drilling fluid, and the sulfate-corrected data are listed in Table T4. The sulfate-corrected data for Holes U1326C and U1326D are illustrated in Figures F21, F22, F23, and F24.

\section{Salinity and chlorinity}

The salinity and chlorinity profiles at this site point to a deeper fluid with a chloride concentration higher than seawater (>585 mM; Fig. F21), indicative of low-temperature diagenetic reactions in the deeper parts of the site. As suggested for Site U1325, a plausible candidate for such a reaction is the alteration of volcanic ash to clay minerals and/or zeolites. These reactions consume $\mathrm{H}_{2} \mathrm{O}$ and, therefore, increase the in situ chlorinity values.

In the zone extending from $\sim 45$ to 270 mbsf (the seismically inferred BSR is at $\sim 230 \mathrm{mbsf}$ ), salinity and chlorinity data show discrete excursions to fresher values, indicating that gas hydrate was present in the cores and dissociated prior to processing the samples, consistent with observations of distinct negative thermal excursions in IR scans (see "Physical properties"). Indeed, the lower salinity and chlorinity points shown in Figure F21 represent samples collected to specifically target the more pronounced IR temperature anomalies. Similar to Sites U1325 and U1328, our observations at this site indicate that gas hydrate predominantly occupies the sandy layers. The minimum salinity and chlorinity values recorded are 4.6 and $90.1 \mathrm{mM}(13.5 \%$ and $16 \%$ of seawater value, respectively) and were measured in a gas hydrate-bearing, $6 \mathrm{~cm}$ thick coarse-sand layer recovered in Sample 311-U1326C-6X-4, 83-96 cm. This sample, retrieved from $44.9 \mathrm{mbsf}$, also represents the first IR temperature anomaly in Hole U1326C. At 
53.4 mbsf, Sample 311-U1326C-7X-3, 74-101 cm, contained small amounts of gas hydrate. Beneath these intense chlorinity and IR anomalies, there is little indication of gas hydrate presence until $\sim 83.8$ mbsf, below which multiple chlorinity excursions, with values as much as 39\% fresher than seawater, were recorded in various sand-bearing intervals.

The degree of dilution of the IW by gas hydrate dissociation shows an approximate linear decrease with depth, from $\sim 48$ mbsf, where the lowest chlorinity and salinity values are observed, to 220 mbsf (Fig. F21). This zone overlaps with the highest gas hydrate concentrations inferred from a zone of high resistivity in the LWD records, which lies between $\sim 70$ and 100 mbsf (see "Downhole logging"). This trend in the gas hydrate distribution suggests that a fault or a steeply dipping sand layer supplies methane to sediment at shallower depths. This is supported by the distinct molecular composition of the gas hydrate at the cemented, coarse sand at 44.9 mbsf and by the observation of a normal fault in the sediment (see "Organic geochemistry" and "Lithostratigraphy;" Fig. F15). The fluid that transports the methane to this layer also has elevated ethane, as indicated in the gas data (see "Organic geochemistry"). There are three additional interesting observations in Figure F21:

1. In the $\sim 20 \mathrm{~m}$ above the seismically inferred BSR, no IR cold anomalies were observed, and the $\mathrm{Cl}$ concentration values are equal or close to the background value.

2. Low chlorinity values associated with IR cold anomalies are observed below the seismically inferred depth of the BSR, at the approximate depth of the base of the gas hydrate stability zone (GHSZ), which is at $275 \pm 25 \mathrm{mbsf}$ based on a geothermal gradient of $\sim 60^{\circ} \mathrm{C} / \mathrm{km}$ (see "Physical properties").

3. The lack of chlorinity and IR anomalies at 215225 mbsf reveals the absence of gas hydrate, the reason for which is as yet unclear.

\section{Biogeochemical processes}

Intense microbial activity at Site U1326 results in sulfate depletion, phosphate and alkalinity production, and significant $\mathrm{Ca}$ and $\mathrm{Mg}$ depletion in the IW of the uppermost $\sim 3 \mathrm{~m}$ (Figs. F22, F23). Linear interpolation of sulfate concentration versus depth places the SMI at 2.5 mbsf; however, we noted a hydrogen sulfide smell to a depth of $\sim 10$ mbsf while cleaning the whole-round samples. Unexpectedly, Sample 311-U1326C-2H-1, 60-75 cm (4.6 mbsf), yielded a sulfate concentration of $7.6 \mathrm{mM}$. The appearance of sulfate below the SMI depth could be caused by rapid sediment redeposition (i.e., a slump) or by contami- nation with drill water during the drilling process. Based on only the shipboard data, it is impossible to distinguish between the two theories.

A first maximum in the $\mathrm{Mg} / \mathrm{Ca}$ ratio is observed in the interval from just below the depth of the SMI at 3.7 mbsf (Fig. F23) to 9.8 mbsf. In this zone, alkalinity and ammonium concentrations also increase. Alkalinity reaches its first maximum of $23.1 \mathrm{mM}$ at 2.9 mbsf and has a second peak of $19.7 \mathrm{mM}$ at $9.8 \mathrm{mbsf}$ (Fig. F22). This uppermost zone of carbonate precipitation is dominated by the preferential loss of Ca relative to $\mathrm{Mg}$. The Ca concentration falls to $~ 33 \%$ of the original seawater value, but the $\mathrm{Mg} / \mathrm{Ca}$ molar ratio increases to about twice that of seawater.

A second zone of intense carbonate diagenesis is indicated by large minima in the $\mathrm{Mg} / \mathrm{Ca}$ ratio and alkalinity, and a minor minimum in ammonium concentration at $\sim 70 \mathrm{mbsf}$, which corresponds to the depth of a sharp Ca maximum to almost twice seawater value (Fig. F23). These distributions are indicative of dolomitization of the calcite that precipitated in the upper zone of carbonate diagenesis. The $\mathrm{Mg}$ involved in the dolomitization reaction has a mixed origin. Some of the $\mathrm{Mg}$ is supplied by the original IW and some was expelled from clay ion exchange sites by the high ammonium concentrations, as suggested by the presence of an ammonium minimum between 40 and 100 mbsf.

A third zone of carbonate diagenesis occurs at $~ 115$ mbsf, where $\mathrm{Ca}$ concentrations show a second intense minimum to $\sim 32 \%$ seawater value. Carbonate precipitation is driven by the high alkalinity and calcium concentration almost twice that of seawater at $\sim 70$ mbsf. At such a high Ca concentration, coupled with the high alkalinity and a very low $\mathrm{Mg} / \mathrm{Ca}$ ratio of 1.1, dolomite cannot form and authigenic calcite precipitates instead.

Sr concentration does not play an important role in the above described carbonate formation and recrystallization zones of the uppermost $\sim 130 \mathrm{~m}$ because the various diagenetic carbonates that form or recrystallize have similar Sr concentrations at the prevailing low temperatures.

The decline in the $\mathrm{Mg} / \mathrm{Ca}$ ratio and increase in $\mathrm{Ca}$ concentrations below $\sim 130$ mbsf are primarily caused by interaction with the deeper fluid, which is forming by alteration of volcanic ash into a Mg-rich clay and zeolites, as suggested by the $\mathrm{K}$ and $\mathrm{Sr}$ depth profiles (Figs. F21, F23).

\section{Inorganic diagenetic processes}

Two zones of high silica concentrations (lithostratigraphic Units I and III; see "Lithostratigraphy") and a zone of low silica concentrations (Unit II; see 
"Lithostratigraphy") are observed (Fig. F24). These zones reflect the depth distribution of diatoms at this site (see "Biostratigraphy").

Lithium shows an interesting concentration depth profile (Fig. F24). $\mathrm{Li}$ is depleted in the uppermost $7 \mathrm{~m}$ and remains low to $\sim 150 \mathrm{mbsf}$, suggesting that some volcanic ash is interspersed in the sediment throughout this depth interval. At the depth where the ammonium concentration reaches the $8.1 \mathrm{mM}$ maximum (157 mbsf), $\mathrm{Li}$ is expelled from the clays by ion exchange reactions. Both $\mathrm{Mg}$ and $\mathrm{Li}$ are released from clay ion exchange sites, but the $\mathrm{Mg}$ binding energy in the clay ion exchange sites is considerably lower than that of Li, explaining the observed stepwise behavior. Li has slightly higher concentrations relative to seawater below the BSR, and therefore is in the deep fluid.

\section{Diagenetic deep fluid}

As indicated in Figures F21, F22, and F24, the deep fluid has higher than seawater chlorinity values, is enriched in $\mathrm{Ca}$ and $\mathrm{Sr}$, and is depleted in $\mathrm{Mg}, \mathrm{K}$, and B. These distributions are consistent with low-temperature volcanic ash alteration reactions that form $\mathrm{Mg}$ and $\mathrm{K}$ clay minerals and K-zeolites. As observed at Site U1325, the original IW is evolving with depth into a $\mathrm{Ca}-\mathrm{Cl}$ brine. Extrapolating the slopes of the $\mathrm{Mg}$ and $\mathrm{Ca}$ concentration versus depth profiles suggests that $\mathrm{Mg}$ should reach zero concentration at $600-700$ mbsf, which is $\sim 200 \mathrm{~m}$ deeper than at Site U1325, and at this depth Ca concentration will be about three times that of seawater.

\section{Organic geochemistry}

The shipboard organic geochemistry program for Site U1326 included analysis of the composition of volatile hydrocarbons $\left(\mathrm{C}_{1}-\mathrm{C}_{5}\right)$ and nonhydrocarbon gases (i.e., $\mathrm{O}_{2}$ and $\mathrm{N}_{2}$ ) from headspace (HS) gas samples, void gas samples, gas samples recovered during PCS degassing experiments, and dissociated gas hydrate. Sediment from the IW squeezecakes was analyzed for inorganic carbon (IC) content (also expressed as weight percent $\mathrm{CaCO}_{3}$ ), total carbon (TC), and total nitrogen (TN). Total organic carbon (TOC) was calculated as the difference between the TC and IC. A total of 70 samples for HS and solid-state analysis were collected at Site U1326. Most of the HS samples were collected on the cut end of core sections facing the IW samples so that the gas and IW data could be integrated. The near-surface sediments from Core 311-U1326C-1H were sampled at high depth resolution to define the SMI. Six pairs of HS samples were collected from inside and outside each IR anomaly interval and were imaged with the IR cam- era to confirm that the samples contained sediment from the cold section of the core.

We collected 44 void gas samples at Site U1326 from depths where gas cracks in the sediment were first observed (6.1 mbsf) to a TD of 269.1 mbsf. A gas sample was also collected from a PCS degassing experiment conducted with Core 311-U1326C-12P (see "Pressure coring").

The primary objectives of the organic geochemistry sampling program at this uplift site were to

- Determine the origin (microbial vs. thermogenic) of the gases recovered by HS gas, void gas, and PCS degassing techniques;

- Investigate the relationship between the gas composition and the distribution of gas hydrate in the system; and

- Describe the carbon and nitrogen contents of the sediments.

\section{Hydrocarbons}

\section{Headspace gas and void gas compositions}

Hydrocarbon HS gas measurements from Holes U1326C and U1326D are listed in Table T5 and plotted relative to depth in Figure F25. Results are reported in parts per million by volume (ppmv) of methane, ethane, ethylene, and propane in the air headspace of a $25.41 \pm 0.18 \mathrm{~mL}$ serum vial and as the millimolar concentration of dissolved methane in the IW (see "Organic geochemistry" in the "Methods" chapter). Methane content increased rapidly from $37 \mathrm{ppmv}$ in the near-surface sample (0.8 mbsf) to $\sim 17,000 \mathrm{ppmv}$ at $6.2 \mathrm{mbsf}$. There was a general trend toward lower HS methane content with depth below 10 mbsf. In the deeper sections of Holes U1326C and U1326D, the methane HS concentration generally varied between $\sim 2000$ and 5000 ppmv. Values above that range were usually associated with samples targeting IR anomalies. Low concentrations of ethane $(<2.0 \mathrm{ppmv})$ were occasionally observed, whereas ethylene and propane were detected in two samples. A few air samples collected from the catwalk area during Site U1326 operations had an average concentration of $2.45 \pm 0.39 \mathrm{ppmv}$ ( $n$ =3) methane, which is slightly higher than the current atmospheric methane concentration $(\sim 1.7$ ppmv). The data reported in Table T5 are uncorrected for the atmospheric contribution.

The composition of gas from voids in the core liner is shown in Table $\mathbf{T} 6$ and displayed relative to depth (excluding methane) in Figure F26. With the exception of several samples that contained a large percentage of air, the void gas was almost entirely methane. Carbon dioxide concentrations ranged between 
$0.0 \%$ and $\sim 0.4 \%$, and hydrogen sulfide was absent in all samples.

Although the $\Sigma \mathrm{C}_{2+}$ hydrocarbon void gas concentrations were $<125 \mathrm{ppmv}$ for all samples, their relative abundance and distribution were valuable for describing the gas hydrate system at Site U1326. Ethane was the most abundant $\mathrm{C}_{2+}$ hydrocarbon in the void gas. Low concentration $(<25 \mathrm{ppmv})$ in the uppermost $35.3 \mathrm{~m}$ was underlain by an interval extending to 72 mbsf with $44-82$ ppmv ethane. In this same interval, two gas hydrate samples were collected, significant pore water freshening (see "Interstitial water geochemistry") was observed, and IR temperature anomalies (see "Physical properties") were imaged. Ethane and methane (the only void gases present in that interval) support Structure I gas hydrate formation (Sloan, 1998). The shallow sediments, therefore, most likely contained Structure I gas hydrate.

With greater depth, ethane concentration returned to the near-surface concentration before increasing again. Increasing ethane concentration was accompanied by increasing propane concentration. Maximum concentrations of ethane (122 ppmv at 244 mbsf) and propane (56 ppmv at $217 \mathrm{mbsf}$ ) occurred near the depth of the seismically inferred BSR ( 234 $\pm 2.5 \mathrm{mbsf}$ ). Isobutane concentration was elevated within the same interval, with a maximum of $\sim 10$ ppmv at 228 mbsf. Propane and $i-C_{4}$ are known Structure II gas hydrate formers (Sloan, 1998). Therefore, enrichment of propane and $i-\mathrm{C}_{4}$ in the void gas is an indication of decomposed Structure II gas hydrate.

There was a marked decrease in the $\mathrm{C}_{1} / \mathrm{C}_{2}$ ratio in the 44-72 mbsf interval where the near-surface gas hydrate was collected. Within that interval, $\mathrm{C}_{1} / \mathrm{C}_{2}$ ratios from void, gas hydrate, and PCS gases were virtually identical (Tables T6, T7).

The $C_{1} / C_{2}$ ratio returned to near-surface values below the shallow gas hydrate zone and then decreased gradually with depth to $\sim 180$ mbsf. The variation of the $i-\mathrm{C}_{4} / n-\mathrm{C}_{4}$ ratio in the deeper cores was, however, more distinct and informative than the $\mathrm{C}_{1} / \mathrm{C}_{2}$ ratio. Whereas $i-\mathrm{C}_{4}$ is sequestered by Structure II gas hydrate, $n-\mathrm{C}_{4}$ is not. Consequently, elevated $i-\mathrm{C}_{4} / n-\mathrm{C}_{4}$ ratio indicates decomposition of Structure II gas hydrate. The $i-\mathrm{C}_{4} / n-\mathrm{C}_{4}$ ratio from $132 \mathrm{mbsf}$ to the base of Hole U1326D was elevated. The maximum value of $i-C_{4} / n-C_{4}(\sim 19)$ occurred at $198.6 \mathrm{mbsf}$ and is a strong indication that Structure II gas hydrate was present at that depth (Fig. F27).

Evidence of different molecular ratios associated with gas hydrate at different depths at the same location suggests that the local gas hydrate system may be supported by different gas-bearing source fluids or that the hydrocarbon composition of the fluids was altered during fluid migration from depth. An association between a steeply dipping sand layer at $\sim 45$ mbsf and concentrated gas hydrate in the shallow horizon indicates fluid migration along structural fractures (see "Interstitial water geochemistry").

Gas composition expressed as the $\mathrm{C}_{1} / \mathrm{C}_{2}$ ratio of $\mathrm{HS}$ and void gas is plotted relative to sediment temperature in Figure F28. Sediment temperature is based on the calculated geothermal gradient of $60^{\circ} \mathrm{C} / \mathrm{km}$ (see "Physical properties"). The monitoring of the $\mathrm{C}_{1} / \mathrm{C}_{2}$ ratio in void and HS gas samples and its relationship to temperature was developed as a safety guideline by the Joint Oceanographic Institutions for Deep Earth Sampling (JOIDES) Pollution Prevention and Safety Panel during the Ocean Drilling Program. $\mathrm{C}_{1} /$ $\mathrm{C}_{2}$ ratios are described as either "normal" or "anomalous" depending upon where they plot relative to the slightly diagonal line in Figure F28. All values measured at Site U1326 were within the acceptable "normal" limits for safe drilling (Pimmel and Claypool, 2001).

\section{Biogeochemical processes}

The IW and HS gases from Cores 311-U1326C-1H and $2 \mathrm{H}$ were sampled at high depth resolution (approximately two samples per $1.5 \mathrm{~m}$ section) to define the SMI. The depth of sulfate depletion was $2.9 \mathrm{mbsf}$, but a deeper "peak" was measured at 4.6 mbsf (Fig. F29). It was suggested that this second peak may be related to a slump feature or drilling fluid contamination (see "Interstitial water geochemistry"). The increasing concentration of methane to 6.2 mbsf is not necessarily consistent with the former interpretation because consumption of methane would be expected at the "second" SMI. The shallow and thin SMI is located between $\sim 2.3$ and 3 mbsf.

\section{Sediment carbon and nitrogen composition}

The sediment IC, carbonate $\left(\mathrm{CaCO}_{3}\right)$, TC, TOC, and TN concentrations and $\mathrm{C} / \mathrm{N}$ ratio from Site U1326 are listed in Table T8 and plotted relative to depth in Figure F30. High-resolution depth profiles were obtained for the uppermost $13 \mathrm{~m}$. No data were obtained below 198 mbsf because the ship was under way in rough seas by the time the samples from that interval were freeze dried. The solid-state carbon and nitrogen vertical profiles displayed transitions that agree remarkably well with the defined lithostratigraphic units (see "Lithostratigraphy"). The carbonate content is relatively high (average $=0.73 \mathrm{wt} \%$ ) in the depth interval corresponding to lithostratigraphic Unit I (0-24.1 mbsf), low in Unit II (24.1- 
$146.3 \mathrm{mbsf}$; average $=0.19 \mathrm{wt} \%$ ), and intermediate in Unit III (146.3-271.4 mbsf; average $=0.41 \mathrm{wt} \%)$. The highest value was measured at $2.15 \mathrm{mbsf}$, which is the depth roughly corresponding with the SMI. TOC displays a similar distribution with average contents of $0.51,0.34$, and $0.45 \mathrm{wt} \%$ in lithostratigraphic Units I, II, and III, respectively. $\mathrm{C} / \mathrm{N}$ ratios in lithostratigraphic Unit I are 11.1 , which indicates the highest terrestrial contribution of organic matter among all sites investigated during Expedition 311. This conclusion is interesting considering Site U1326 is the greatest distance from land. $\mathrm{C} / \mathrm{N}$ ratios in lithostratigraphic Units II (average $=\sim 8$ ) and III (average $=\sim 7.7$ ) are similar, though a low $\mathrm{C} / \mathrm{N}$ value of 2.1 at 131 mbsf skewed the average value for lithostratigraphic Unit II downward.

\section{Microbiology}

Site U1326 is located along the transect of sites established during Expedition 311 across the northern Cascadia accretionary prism at the westernmost uplifted ridge of the accretionary prism. It was the last site sampled for microbiology. Efforts continued to obtain live anaerobic methane oxidizers, potentially unknown gas hydrate-associated microbial communities, high pressure adapted microorganisms, and methanogens. Subsampling for direct cell counts and biological contamination tests continued at this site.

\section{Microbiological sampling}

Sampling from the mudline (Sample 311-U1326C$1 \mathrm{H}-1,0-3 \mathrm{~cm}$ ) in Hole U1326C and the deepest core (Sample 311-U1326D-20X-1, 70-80 cm; $263 \mathrm{mbsf}$ ) in Hole U1326D targeted microorganisms for aerobic and anaerobic high-pressure culturing.

Methanogenesis can occur in most anaerobic environments, but it becomes the major metabolic strategy when other electron donors such as nitrate, $\mathrm{Fe}(\mathrm{III})$, and sulfate are depleted. We sampled regularly downhole to below the depth of the predicted BSR to quantify methanogenesis in these sediments (see "Microbiology" in the "Methods" chapter).

\section{Contamination tests}

Contamination tests at previous sites had verified that the interior of APC cores and the center of biscuits in XCB cores yielded samples with low amounts of exogenous microbial contamination. At this site we focused contamination tests on sand layers, gas hydrate-bearing sediments, and shallow APC cores where soupy texture is common.

\section{Perfluorocarbon tracers}

Samples for perfluorocarbon tracers and fluorescent microsphere analyses were taken immediately from the ends of APC whole-round cut sections on the catwalk. Extra sediment samples for microsphere analysis were collected from split cores in the core laboratory because it was possible to differentiate between sand layers, biscuits, and drilling slurry. Sediment samples associated with gas hydrate were collected from the ends of whole-round sections when the presence of gas hydrate was indicated by the data collected on the catwalk using the IR camera. Samples were analyzed as described and the raw data are presented in Table T9.

\section{Fluorescent microspheres}

We detected very small but nonzero numbers of fluorescent microspheres in the interior of the mudline APC core, which was very soupy at this site. Tests on sand layers, which were widely distributed at this site, showed that the interiors of sand layers were possibly contaminated with microspheres but at a very low level. One of the gas hydrate-bearing samples indicated that the interior of the sediment was contaminated with the microspheres at a very low level.

\section{Shipboard analysis}

Samples were taken from the top (Sample 311U1326C-1H-1, 0-3 cm) and bottom (Sample 311U1326D-20X-1, 70-80 cm; $263 \mathrm{mbsf}$ ) of the sedimentary section for inoculation of enrichment cultures targeting high-pressure adapted heterotrophic and sulfate-reducing microorganisms. Samples were maintained at low temperature, and dilution series were inoculated to culture for microorganisms at $55.1 \mathrm{MPa}$ and $4^{\circ} \mathrm{C}$. Cultures for sulfate reducers required preparation in the anaerobic chamber and were fed formate, acetate, or lactate as a carbon source.

\section{Physical properties}

Site U1326 is located at the crest of the westernmost accretionary ridge on the Expedition 311 transect across the northern Cascadia margin accretionary complex. A major objective of this site was to determine the physical properties and gas hydrate distribution in this distal accretionary ridge.

Physical properties were measured in cores recovered from Holes U1326B, U1326C, and U1326D. Hole U1326C extended to 86.7 mbsf, where it was abandoned for technical reasons. Coring in Hole U1326D began at $78.8 \mathrm{mbsf}$ and continued to $271.4 \mathrm{mbsf}$. 
Figure F31 presents an overview of the physical property data obtained from these two holes. All cores from this site were systematically scanned upon arrival on the catwalk to detect IR anomalies indicative of gas hydrate dissociation during core recovery. Cold temperature anomalies were observed at a wide range of depths from 40 to $250 \mathrm{mbsf}$, and catwalk sampling was conducted based on these IR scans. Numerous IW samples were taken based on the IR images to extend the chlorinity anomaly database and to calibrate IR data as a proxy for in situ gas hydrate concentration. Two sections with thick sandy and silty zones and high gas hydrate saturation were examined in more detail. In the following sections we discuss these data and compare them to data acquired at other sites.

\section{Infrared images}

All cores were scanned on the catwalk following the track-mounted IR camera procedures described in "Physical properties" in the "Methods" chapter. Portable Document Format images of the scans of all cores are available in the "Site U1326 core descriptions." Temperature arrays in the format of commaseparated value files were exported from the IR camera software and then concatenated for each core. The arrays were then further concatenated for all cores available in a given hole. Figure F32 shows cold thermal anomalies in the concatenated false-color IR images for Holes U1326C and U1326D. This figure also shows the Hole U1326A LWD resistivity data and the pore water saturation derived from these data for comparison.

As a precursor to quantitative studies of the temperature anomalies, downhole temperatures were averaged for each pixel row in the IR temperature array, excluding pixels $\sim 1 \mathrm{~cm}$ from the edge of the image and $2 \mathrm{~cm}$ along the midline of the image to eliminate the major thermal artifacts in the images. On first look, a striking aspect of Hole U1326D is that it is consistently colder below $\sim 150$ mbsf (Fig. F33A). Comparison of the temperature profile with the ambient temperature on the catwalk indicates that this change in core liner temperature is closely correlated with a rapid change in ambient air temperature. The IR camera measures the temperature of the surface of the core liner, which is a function of the gradient between the air temperature outside the liner and the temperature of the core. In Figure F32, the cold core liner temperature makes it more difficult to see that the entire interval from 40 mbsf to the base of Hole U1326D contains many distinct cold anomalies. The $\Delta T$ s of these cold anomalies are not affected by changes in ambient temperature because the back- ground temperature and the cold temperature excursions are affected equally. Figure F34 shows the ambient temperature and light intensity on the catwalk for the entire expedition and the acquisition times of individual cores. During the first 9 days of the cruise, when LWD data were acquired, light intensity and temperature show strong diurnal variations. During coring, skies were overcast and openings in the catwalk wall were shielded; consequently, ambient temperatures varied in a relatively small range except for cold periods on 2 October and 25 October 2005.

Many of the IR anomalies were used to identify samples for IW chemical studies. Sample 311-U1326C$6 \mathrm{X}-4,83-96 \mathrm{~cm}$, is shown in Figure F35. This sample contained pore-filling gas hydrate in a $4-5 \mathrm{~cm}$ thick, medium- to coarse-grained sand layer. The gas hydrate appeared to be filling pores in the sand. Upon physical dissection, it was clear that the central part of the sand layer contained more gas hydrate than sediment, suggesting both pore-filling and grain-supporting gas hydrate in this sample. The IR image and temperature profile in Figure F35 show that the temperature of the gas hydrate at the time of core processing was as low as $-2.4^{\circ} \mathrm{C}$. The chlorinity anomaly corresponding to this IR anomaly was $197.7 \mathrm{mM}$, which represents very strong pore water freshening (see Table T3). A moisture and density (MAD) sample was taken from the sand layer containing the gas hydrate. This sample was notable for its relatively coarse grain size and the occurrence of buff-colored fine silt or clay coating on the sand grains after drying. MAD results were as follows: bulk density $=2.21$ $\mathrm{g} / \mathrm{cm}^{3}$, grain density $=2.84 \mathrm{~g} / \mathrm{cm}^{3}$, and porosity $=$ $34.7 \%$. The porosity value is among the lowest measured and is consistent with the relatively coarse grain size of the sample.

Another notable gas hydrate occurrence was at 246 mbsf in Hole U1326D. The lower part of Core 311U1326D-18X was characterized by an unusually thick cold anomaly (Fig. F33B, F33C). The upper part of this anomaly was processed by the inorganic geochemists and the lower part (Section 311-U132618X-4) was opened immediately after sectioning on the catwalk. The sediment in this core (Fig. F33D) had a very unusual texture. It remained cohesive and was "foamy" rather than being soupy or mousselike (i.e., it felt like foam rubber to the touch). Sediment in this section lost its foamy texture in $<1 \mathrm{~h}$, collapsing to a stiff, dry sediment that occupied $\sim 25 \%$ of the original volume in the core liner. Additional analyses will be performed postcruise to better understand the reasons for and implications of this unusual sediment character. 


\section{Sediment density and porosity}

Gamma ray attenuation (GRA) densities were measured on the multisensor track (MST) and bulk density, grain density, and porosity were calculated from the measured wet and dry weights and dry volume of the sediments (MAD measurements; Table T10). Both estimates of density were compared to in situ densities measured by the LWD/MWD tools (Fig. F31). Significant differences are seen between MAD and LWD porosities in the uppermost $25 \mathrm{~m}$ of Hole U1326C, indicating significant lateral heterogeneity over the $\sim 25 \mathrm{~m}$ between Holes U1326A and U1326C or, more likely, problems with the LWD data at these shallow depths. MAD porosities of $53 \% \pm 5 \%$ in the uppermost $20 \mathrm{~m}$ are unusually low for near-seafloor sediments. The data, however, are consistent with relatively high shear strengths and with unusually high $P$-wave velocities recorded both on the Hamilton frame and by wireline logging. A possible explanation for the difference in shallow sediment characteristics between holes at this site is the presence of a fault between the holes, consistent with the seismic data and uplifted nature of Site U1326. Mass wasting that reveals previously buried and overconsolidated sediments may also be a factor at this site.

\section{Magnetic susceptibility}

Magnetic susceptibility at this site was generally high and variable, except in the uppermost $10 \mathrm{~m}$ (Fig. F31). Causes for the variability in magnetic susceptibility will be a topic for postcruise research. It is likely related to variable input of silty and sandy turbidites, reflecting different sedimentary environments.

\section{Compressional wave velocity from the multisensor track and Hamilton frame}

$P$-wave velocities were measured using both the MST and the Hamilton frame on a limited number of sections from the top of Hole U1326C (Table T11). Velocity measurements ranged from 1480 to $1580 \mathrm{~m} / \mathrm{s}$. Velocities at Site U1326 are much higher in the shallow subsurface than at other sites (Fig. F36). This correlates well with the shear strength data and may be related either to a high carbonate content in the sediments or to mass wasting, which would have exposed previously buried sediments at the seafloor.

\section{Shear strength}

Shear strength measurements were made in Holes U1326C and U1326D using both the automated vane shear (AVS) system and the handheld Torvane (Tables T12, T13). Measurements were made on the working half of the split core after resistivity, veloc- ity, and MAD samples had been taken. Efforts were made to take measurements in areas of the core where the sediment was undisturbed by gas expansion and drilling cracks. Measurements were also taken as close as possible to where MAD samples had been extracted. At the top of Hole U1326C, at least two Torvane measurements and one AVS measurement were taken per section. The number of measurements decreased deeper in the hole because of increased disturbance in the cores.

Shear strength generally increases with depth (see Fig. F31 for all shear measurements and Fig. F37A for measurements from 0 to 120 mbsf). Shear strength ranges from $5 \mathrm{kPa}$ in sands to $300 \mathrm{kPa}$ in clay. Shear strengths are unusually high in the shallow subsurface (Fig. F37A). The ratio of shear strength to overburden pressure (Fig. F37B) is a measure of the consolidation state of the sediments. A ratio $>0.25$ indicates that the sediments are overconsolidated for their depth below the seafloor. Overconsolidation can be seen in the uppermost $20 \mathrm{~m}$ of Hole U1326C (Fig. F37C). This correlates well to the high $P$-wave velocity and may be caused by high carbonate content in the shallow sediments or to mass wasting, which has been documented nearby and would have exposed previously buried sediments at the seafloor.

\section{Electrical resistivity}

Electrical resistivity was measured in Holes U1326B, U1326C, and U1326D using both the contact and noncontact methods. Measurement interval using the contact system varied depending on the quality of the core. Measurements taken with the noncontact method were made every $2.5 \mathrm{~cm}$. Gas expansion of the core caused the results to be very scattered. The high degree of scatter may also be caused by the large amount of sand at this site.

Resistivity values ranged from 0.3 to $2.5 \Omega \mathrm{m}$ (Table T14; Fig. F38A). The higher value obtained at $\sim 45$ mbsf was attributed to cracks in the sediment. The formation factor was calculated for the contact resistivity measurements assuming a pore water salinity of $3.4 \%$ (Fig. F38B). Pore water resistivities were calculated from the IW salinities using equations developed by Fofonoff (1985) and corrected to $20^{\circ} \mathrm{C}$ (Fig. F38A). Archie's parameters were then determined by fitting Archie's equation to the formation factor and MAD porosities (Fig. F38D). Because of the wide range of resistivity and the large number of sand layers within the cores, two sets of parameters were determined: one for porosities $>0.45$ and the other for porosities $<0.45$. For porosities $>0.45$, the cementation coefficient $m=1.38$ and the tortuosity coefficient $a=1.78$. For porosities $<0.45, m=1.64$ and $a=1.11$. For comparison with the MAD porosi- 
ties, porosities were calculated from the formation factor using the first set of parameters. (Fig. F38C).

\section{Thermal conductivity}

Thermal conductivity values were less scattered at this site than at other sites (Table T15; Fig. F31). Examination of split cores in the intervals in which the measurements were taken suggests that thermal conductivities $<0.9 \mathrm{~W} /(\mathrm{m} \cdot \mathrm{K})$ are associated with core disturbance caused by gas expansion. Thermal conductivities of $0.9-1.1 \mathrm{~W} /(\mathrm{m} \cdot \mathrm{K})$ appear to generally be related to clay-rich intervals, whereas thermal conductivities $>1.1 \mathrm{~W} /(\mathrm{m} \cdot \mathrm{K})$ appear to be related to coarser grained intervals. This relationship will be examined more carefully postcruise. For determination of in situ temperature and heat flow, a constant thermal conductivity value of $1.1 \mathrm{~W} /(\mathrm{m} \cdot \mathrm{K})$ was assumed.

\section{In situ temperature profile}

Four deployments of temperature tools were attempted at Site U1326 (Table T16). A third-generation advanced piston corer temperature (APCT-3) tool deployment on Core $311-\mathrm{U} 1326 \mathrm{C}-4 \mathrm{H}$ at 30.4 mbsf provided very good quality data (Fig. F39), although the initial frictional pulse was unusually high. The extrapolated temperature at this depth of $4.30^{\circ} \mathrm{C}$ is similar to the temperature of $4.44^{\circ} \mathrm{C} \mathrm{ob}-$ tained at $33 \mathrm{mbsf}$ at Site U1325. Unfortunately, the transition to XCB coring occurred immediately after this core, so that no more APCT-3 measurements were possible at this site.

Given the high ship heave, a worsening weather forecast, and limited time available at this last site, the decision was made to only attempt DVTP measurements near the expected base of the GHSZ. Three attempts were made at depths of 252, 271.4, and 300 mbsf. For the last two attempts, mud was pumped into the borehole in an attempt to damp the effect of heave. All three attempts briefly penetrated the seafloor but did not remain coupled to the sediment long enough to estimate in situ temperature by modeling the decay of the frictional pulse generated by probe insertion. Instead, the data show a gradual increase in temperature that appears to approach temperatures in the range of $16^{\circ}-19^{\circ} \mathrm{C}$. Because of questions about the depth to the base of the GHSZ at this site, postcruise work will include an attempt to estimate the in situ temperature by modeling heating of the borehole by the surrounding rock.

Figure F40 shows a compilation of all in situ temperature estimates from Expedition 311 compared to results from Site 889 . The implied heat flow, assuming a constant thermal conductivity of $1.1 \mathrm{~W} /(\mathrm{m} \cdot \mathrm{K})$, is also shown and compared to the regional heat flow determined by Hyndman and Wang (1993). Temperatures at Site U1329 are clearly higher at a given depth. Heat flow across the lower slope (Sites U1325, U1327, and U1328) appears to be depressed compared to the regional heat flow pattern, consistent with perturbation by a high sedimentation rate and upward fluid advection (Hyndman and Davis, 1992). Postcruise analysis will focus on detailed examination of data uncertainties and on the processes that can explain intersite and intrasite variation.

\section{Paleomagnetism}

Note: This section was contributed by Jennifer Henderson and Katerina Petronotis (Integrated Ocean Drilling Program, Texas A\&M University, 1000 Discovery Drive, College Station TX 77845, USA).

Alternating-field (AF) demagnetization of the sedimentary archive-half sections was used to determine the remanent magnetization components recorded in the recovered core (Fig. F41). The paleomagnetic data will be used postcruise to characterize the magnetic properties of the sediments and to construct a magnetostratigraphy of the sedimentary section recovered at Site U1326. The AF demagnetization applied at 10 and $20 \mathrm{mT}$ should have removed most of the drill string magnetic overprint, but postcruise demagnetization at higher fields will most likely be required.

Questionable data may be associated with remanence measurements over intervals disturbed or deformed by coring. Similarly, magnetic edge effects, which can be large when measurements are within $\sim 5 \mathrm{~cm}$ of the edge of a section or void, can give biased results. To avoid interpreting results in these regions, we manually noted the disturbed intervals and voids in the cores. Data from these intervals will be removed prior to postcruise interpretation.

\section{Pressure coring}

The main objectives of pressure coring during Expedition 311 were to quantify natural gas composition and concentration in sediments and to determine the nature and distribution of gas hydrate and free gas within the sediment matrix. To achieve these objectives, we

- Measured the quantity and composition of gases released during controlled degassing experiments,

- Conducted nondestructive measurements (X-ray imaging, $P$-wave velocity, gamma ray density) at in situ pressure and during degassing, and 
- Preserved hydrate-bearing sediments at in situ pressure for more comprehensive shore-based investigations.

Nondestructive measurements not only provide a direct indication of the existence of gas hydrate, but the resulting data (acoustic impedance) can be used to help interpret regional seismic data. Site U1326, situated on the first uplifted ridge, had a strong BSR. The LWD/MWD data from Hole U1326A displayed the highest resistivity values seen during Expedition 311 , with gas hydrate saturations calculated from Archie's equation as high as 60\% (see "Gas hydrate and free gas occurrence"). There were also high resistivities below the estimated depth of the BSR (234 mbsf), potentially indicating free gas (see "Gas hydrate and free gas occurrence"). Specific objectives at Site U1326 were to confirm and quantify the presence of gas hydrate above the BSR, targeting the very high resistivity layer near $90 \mathrm{mbsf}$, and free gas below the BSR.

\section{Operation of pressure coring systems}

Pressure coring tools were deployed only three times at Site U1326 (Table T17): one FPC core (Core 311U1326C-11Y), one PCS core (Core 311-U1326C-12P), and one HRC core (Core 311-U1326C-13E). The pressure coring tools were deployed in succession in a narrow interval between 82.7 and 86.7 mbsf, where the Hole U1326A LWD data had shown very high resistivity values. Figure F42 shows the pressure history of the cores during deployment, coring, recovery, and chilling in the ice shuck. Figure F43 displays the same data plotted as a pressure/temperature trajectory, showing the stark contrast between a deployment where the core remains clearly inside the gas hydrate stability field (Core 311-U1326C-11Y) and one that ends up in the laboratory well outside the gas hydrate stability field (Core 311-U1326C-12P).

The FPC deployment that recovered Core 311U1326C-11Y was unexceptional until the sand line tension, when lifting the bit from the BHA exceeded the expected load by 2 tons. It was later concluded that a significant amount of sand had entered the BHA and had hindered the recovery. Scouring the outer barrel of the FPC also indicated clean sand had been penetrated. The autoclave was retrieved under nearly full pressure (17.5 $\mathrm{MPa}$, compared with an in situ pressure of $19.2 \mathrm{MPa}$ ). X-ray images showed that this core was very short $(15 \mathrm{~cm})$ and situated in the center of the core barrel, implying that the core below it had washed out of the core liner. The liner and recovered portion of Core $311-\mathrm{U} 1326 \mathrm{C}-11 \mathrm{Y}$ were transferred from the autoclave, analyzed in the Pressure Multisensor Core Logger (MSCL-P; see "Measurements on HYACINTH cores"), and transferred to a storage chamber for further shore-based studies.
The PCS deployment (Core 311-U1326C-12P) recovered a partial core at $3.4 \mathrm{MPa}$. While the core was in the X-ray system, we observed a gas bubble trapped in the inner core barrel. After degassing was completed, the short core was extruded and some very coarse sand and rocky material was found in the outer core barrel.

During the final deployment with the HRC (Core 311-U1326C-13E), the lower part of the autoclave and bit assembly were lost, ending operations in Hole U1326C. The failure was the result of two joints becoming unscrewed during coring. Fine sand found near the top of the tool, $11 \mathrm{~m}$ above the bottom, led us to conclude that sand and fluid must have flowed back up the BHA and into the tool during the deployment, jamming the corer in a way that allowed the left-hand threads to come unscrewed.

\section{Degassing experiments}

At Site U1326, Core 311-U1326C-12P, which was the only PCS core recovered successfully under pressure, was investigated by controlled shipboard degassing experiments (Table T18). This core was taken at a depth of 83.7 mbsf.

The degassing experiment included the following steps. First, the volume and density of sediment inside the inner core barrel of the PCS was monitored by X-ray analysis. Next, the PCS was slowly degassed in a temperature-controlled laboratory $\left(7^{\circ} \mathrm{C}\right)$, and the volume and composition of released gas and water, the pressure inside the core, and the ambient air pressure and temperature were monitored (Table T19) as described in "Pressure coring" in the "Methods" chapter. During the degassing procedure, the vertical density distribution of the PCS cores was repeatedly determined by GRA scans to examine the evolution of gas voids within the sediment. After degassing was completed, we X-rayed the PCS core again, collected the water remaining in the outer core barrel for mass balance considerations, curated the sediment that was extruded from the core, and subsampled it for IW chemistry, dissolved gases, and physical property analyses.

The degassing of Core 311-U1326C-12P yielded $21.0 \mathrm{~L}$ of gas. The composition of the released gas did not change significantly in the course of degassing (Table T19). Methane was the major component, accounting on average for $91.7 \% \pm 2 \%$ of the emitted gas. Nitrogen was the second most abundant gas, contributing $6.1 \% \pm 3 \%$ to the gas released. Carbon dioxide, ethane, and higher hydrocarbon concentrations were below the detection limit of the Agilent gas chromatograph used for continuous gas analysis during the degassing experiment (Table T19). A subset of gas samples was analyzed using 
methods described in "Organic geochemistry" in the "Methods" chapter and yielded an average ethane value of $54 \mathrm{ppmv}$ and $\mathrm{C}_{1} / \mathrm{C}_{2}$ ratios $>16,000$. Recovery was particularly low for Core 311-U1326C$12 \mathrm{P}$; the recovered core length was estimated at 35$40 \mathrm{~cm}$ from the gamma ray density profiles, though only $27 \mathrm{~cm}$ of sediment was extruded from the $1 \mathrm{~m}$ long PCS core barrel. Assuming that all methane was released from $40 \mathrm{~cm}$ of recovered sediment, mass balance calculations yield a pore space methane concentration of $2965 \mathrm{mM}$. This concentration equates to $35 \%$ of free gas or $40 \%$ of gas hydrate in the pore space (Tables T20, T21; Fig. F44). The pressure inside the PCS core dropped below the predicted gas hydrate stability conditions when the port valve of the PCS was first opened and water expanded from the outer core barrel into the manifold system. Therefore, no pressure plateaus or rebounds from dissociation of gas hydrate could be expected and a steady decrease of core pressure versus removed gas volume was observed (Fig. F45).

The X-ray image taken before the core was degassed (Fig. F46) showed $28 \mathrm{~cm}$ of sediment at the top of the barrel, along with a gas bubble in the inner core barrel below this sediment. The water below the sediment also appeared to contain some suspended sediment. Repeated gamma ray density profiles (Fig. F46) showed that the sediment at the top of the core remained stationary throughout the degassing experiment, and that a small plug of sediment $(\sim 10 \mathrm{~cm}$ long) near $60 \mathrm{~cm}$ core depth also stayed in place during degassing. However, by the time the final X-ray image was taken, the lower plug of sediment had been homogenized and distributed along the core. Chlorinity measurements in the upper portion of the core show pore water freshening.

\section{Measurements on HYACINTH cores}

Simultaneous and automated gamma ray density, $P$ wave velocity, and X-ray measurements were made in the MSCL-P system on Core 311-U1326C-11Y. All measurements took place at $18 \mathrm{MPa}$ (near recovery pressure; $95 \%$ of in situ pressure). The velocity and density profiles are shown alongside the X-ray image in Figure F47. The sediments have high velocities compared to density (Fig. F48) indicating there may be some gas hydrate in this short sample, especially when compared to other pressure cores retrieved during Expedition 311 (see "Pressure coring" in the "Site U1327" chapter). This core was transported to the Pacific Geoscience Center, Sidney, B.C., directly after Expedition 311 and was rapidly depressurized. When the core was removed from the storage chamber, some bubbling and "fizzing" was observed in the hard silty material. The sample was considered to be too small and disturbed to warrant being stored under pressure and was curated in a plastic bag.

\section{Gas hydrate concentration, nature, and distribution}

Mass balance calculations were only performed for Core 311-U1326C-12P, recovered from a depth of 83.7 mbsf. The gas hydrate content is estimated at $40 \%$, placing it in the GHSZ (Fig. F44) regardless of the choice of thermal gradient (see "In situ temperature profile"). This pressure core was targeted at a zone of extremely high resistivity seen in the LWD data from Hole U1326A, and we can confirm that this high-resistivity zone contains gas hydrate.

IR images (see "Infrared images") and visual observations in the chemistry laboratory show that most of the gas hydrate is associated with sandy layers at Site U1326. Core 311-U1326C-11Y captured some extremely coarse sands and indurated material that was observed to fizz upon depressurization and warming and most likely contained gas hydrate. The core material missing from the base of this core, the sediment/water/gas mixture in the PCS, and the spectacular, spontaneous disassembly of the HRC highlight the difficulty in recovering gas hydratebearing sands.

\section{Downhole logging}

\section{Logging while drilling}

\section{Operations}

Hole U1326A was spudded at 1839 mbrf water depth (drillers depth) at $1320 \mathrm{~h}$ on 22 September 2005. LWD tools included the GeoVISION resistivity tool, the EcoScope tool, the SonicVISION tool, the TeleScope MWD tool, the ProVision nuclear magnetic resonance tool, and the ADNVISION tool. For details on each tool and the measurements it makes, see "Downhole logging" in the "Methods" chapter.

Similar to the other sites, the uppermost $10 \mathrm{~m}$ of the hole was drilled with a rotation rate of $10-15 \mathrm{rpm}$, a pump flow rate of $190 \mathrm{gpm}$, and an ROP of 10-15 m/ $\mathrm{h}$. We then increased these rates to $40 \mathrm{rpm}$ and 220 gpm until $30 \mathrm{mbsf}$, and then to $60 \mathrm{rpm}$ and $270 \mathrm{gpm}$ (to start the MWD telemetry), keeping the instantaneous ROP below $50 \mathrm{~m} / \mathrm{h}$ with depth. The target depth of 300 mbsf (2139 mbrf) was reached at 0410 $\mathrm{h}$ on 23 September. Considering the proximity between Holes U1326A and U1327A ( 8 nmi apart), it was decided to raise the drill string above the seafloor and move by DP to the location of Hole U1327A without tripping back to the surface. 


\section{Gas monitoring with real time logging-while- drilling/measurement-while-drilling data}

The LWD logs were acquired to plan coring and pressure coring operations in subsequent holes at Site U1326. As Hole U1326A was drilled without coring, the LWD/MWD data had to be monitored for safety to detect gas entering the borehole. As explained in "Downhole logging" in the "Methods" chapter, the primary measurement used for gas monitoring was annular pressure while drilling, which is measured by the EcoScope tool in the borehole annulus. We looked for sudden decreases $>100$ psi in the annular pressure, which could be caused by low-density gas entering the borehole. We also monitored pressure increases of the same magnitude, which could be the result of fluid acceleration caused by a gas kick (Aldred et al., 1998).

Figure F49 shows the measured borehole fluid pressure profile in Hole U13265A after subtraction of the best-fit linear trend. The borehole fluid pressure shows only small fluctuations over the trend, except for a positive pressure anomaly ( $\sim 30 \mathrm{psi})$ centered at 182 mbsf. Whereas positive drilling fluid pressure anomalies at other sites were correlated with hole enlargements, the ultrasonic caliper log (Fig. F49) shows no hole diameter anomaly near 182 mbsf; thus, the reason for the pressure increase is not clear. One possibility is that a partial borehole collapse somewhere above the LWD string caused a sudden influx of cuttings in the annulus. The observed fluid pressure anomalies were well below the 100 psi level that would have required preventive action.

We also monitored the coherence of the sonic waveforms acquired by the SonicVISION tool, focusing on the velocity of the fluid wave in the borehole. Loss of coherence in the waveforms and a slower velocity for the drilling fluid indicate the presence of gas. The sonic waveform coherence image in Figure F49 shows almost everywhere a well-defined fluid arrival with a slowness of $\sim 200 \mu \mathrm{s} / \mathrm{ft}$, which corresponds to the expected fluid velocity of $\sim 1500 \mathrm{~m} / \mathrm{s}$. The only anomalies are at two intervals (80-87 and 258-261 mbsf), where the fluid arrival suddenly disappears. As will be shown later, these two intervals are characterized by high resistivity. The shallower one is presumably a gas hydrate-rich interval where some gas hydrate dissociation may have generated free gas during drilling. The deeper interval is located below the BSR depth, estimated from seismic reflection data (234 mbsf), and may contain free gas. Even if the low coherence of the drilling fluid arrival was caused by free gas, it is important to stress that the fluid pressure anomalies were small and that if gas was in the drilling fluid it had to be in low concentrations.

\section{Logging data quality}

Figure F49 also shows the quality control logs for Hole U1326A. The ROP was generally $60 \mathrm{~m} / \mathrm{h}$ or less in the interval from the seafloor to TD. This is sufficient to record one measurement every $4 \mathrm{~cm} \quad(\sim 25$ measurements $/ \mathrm{m}$ ) in the GeoVISION resistivity, and no significant resolution loss was observed with variation in ROP. The ultrasonic caliper log, which is a direct measurement of the borehole diameter recorded by the EcoScope tool, is our best indicator of borehole size. It shows a large washout near the seafloor (10-20 mbsf), where the hole diameter reached 13 inches $(33 \mathrm{~cm})$, and many smaller hole enlargements throughout the rest of the hole. In several cases, borehole diameter restrictions ( $<9$ inches or 23 $\mathrm{cm})$ can be observed immediately below these enlargements (e.g., at 110, 206, and 226 mbsf), suggesting that the washouts were generated above resistant intervals that were hard to drill. Except for these enlargements and restrictions, the hole diameter was generally just above 10 inches $(25 \mathrm{~cm})$.

Despite these hole irregularities, the density correction, calculated from the difference between the short- and long-spaced density measurements, generally varies from 0 to $0.2 \mathrm{~g} / \mathrm{cm}^{3}$ (Fig. F49), showing the good quality of the density measurements. Figure F50 is a summary of the Hole U1326A LWD gamma ray, density, resistivity, and resistivity image logs with density and porosity measurements from cores from Holes U1326C and U1326D superimposed (see "Physical properties").

The depth relative to the seafloor was fixed for all LWD logs by identifying the step change in the gamma ray log associated with the seafloor. For Hole U1326A, the gamma ray logging pick for the seafloor was at a depth of 1838 mbrf.

\section{Wireline logging}

\section{Operations}

Hole U1326D was drilled to a depth of 300 mbsf, which was reached at $1330 \mathrm{~h}$ on 26 October 2005. The weather conditions were favorable (ship's heave was $\sim 3 \mathrm{~m}$ ), but because of a poor weather forecast that required that we leave the site by midday on 27 October, it was decided to run a single, armless tool string that included the most critical log still missing (sonic velocity). The tool string consisted of the SGT, the DSI, and the DIT. For details on the different tools, see "Downhole logging" in the "Methods" chapter.

After hole preparation, rig up of the tool string started at $2210 \mathrm{~h}$ and was completed at $2308 \mathrm{~h}$ on 26 October. The bottom of the hole was reached without complications at $2139 \mathrm{mbrf}$ (302 mbsf), and we 
started logging a first pass at $0034 \mathrm{~h}$ on 27 October. The first pass was completed at $1936 \mathrm{mbrf}$ (99 mbsf), with the top of the $34 \mathrm{~m}$ long tool string just below the drill pipe. We lowered the tool string to the bottom of the hole again and started a second pass at $0127 \mathrm{~h}$. The tool string reached the seafloor at 0235 $\mathrm{h}$, and was pulled back onto the rig floor at $0345 \mathrm{~h}$. Rig down of all wireline equipment was completed at $0505 \mathrm{~h}$ on 27 October.

\section{Logging data quality}

As we did not run a caliper log in Hole U1326D, we cannot clearly determine the effects of hole diameter on the wireline logging measurements. There are a few intervals (e.g., 100 and 180 mbsf) where both the gamma ray and the induction resistivities have very low values, which could be the result of an enlarged hole (Fig. F51). Apart from these anomalous intervals, the gamma ray and induction logs are of very good quality.

A comparison of the gamma ray, resistivity, and acoustic logs measured in the two passes show an excellent correlation (Fig. F51). The acoustic waveforms and slowness-time coherence projection are shown in Figure F52. The velocity profiles acquired in the two passes are very similar, and almost no additional processing was required to derive reliable compressional $\left(V_{\mathrm{p}}\right)$ and shear $\left(V_{\mathrm{s}}\right)$ wave velocities.

Despite the absence of caliper data, the analysis of the sonic waveforms and coherences in Figure F52 suggests that the borehole was in good condition. The very clear $P$-wave arrivals in the monopole waveforms generate a strong coherence peak that makes $V_{\mathrm{p}}$ labeling extremely robust over the entire hole. In addition to the clear $P$-wave arrivals, the monopole waveforms also display a strong arrival at $\sim 2 \mathrm{~ms}$, which likely corresponds to a fluid wave with a uniform velocity that creates a second coherence "track" at a nearly constant velocity of $\sim 1500 \mathrm{~m} / \mathrm{s}$. In the interval between $\sim 70$ and $80 \mathrm{mbsf}$, where both velocity and resistivity are very high, the monopole waveforms display low amplitudes that are characteristic of very high gas hydrate concentrations. The low waveform amplitudes for most of the lower dipole and a portion of the upper dipole could possibly result from the attenuating influence of disseminated gas hydrate. This effect would be accordingly stronger on the higher frequency waveforms from the lower dipole. This effect could also be the result of poor hole conditions, but the high quality of the monopole waveforms suggests otherwise.

The depths relative to seafloor for all of the wireline logs were fixed by identifying the step change in the gamma ray $\log$ associated with the seafloor. The gamma ray pick for the seafloor was at 1837 mbrf in Hole U1326D.

\section{Logging-while-drilling and wireline logging comparison}

Figure F53 shows a comparison of LWD (Hole U1326A) and wireline (Hole U1326D) data, using the gamma ray and resistivity logs. The LWD gamma ray log gives higher readings (100 gAPI on average) than the wireline log (40 gAPI on average), and the curves do not have features that can be easily correlated. Part of the reason for this difference may be that the wireline gamma ray log has not been corrected for the effect of hole size, as we could not run a caliper $\log$. The ultimate reason for this discrepancy is not clearly understood. However, wireline data are consistent with data recorded during Leg 146.

The comparison of resistivities shows similar values measured by the LWD and wireline logs. The prominent, asymmetric resistivity high that is clearly visible in the LWD logs at 72-100 mbsf (Fig. F50) is found with the same shape in the wireline resistivity logs, only displaced upward by $\sim 12 \mathrm{~m}$ to $60-88 \mathrm{mbsf}$. Hole U1326D, where the wireline logs were measured, was drilled $\sim 20 \mathrm{~m}$ southwest of LWD Hole U1326A. As described in "Logging-while-drilling borehole images," borehole images show layers steeply dipping to the north-northeast. A northwarddipping structure is consistent with finding the same stratigraphic horizon in a shallower position in Hole U1326D compared to Hole U1326A. The resistivity peak centered around 260 mbsf in the LWD resistivity logs, on the other hand, does not clearly correlate to a similar shallower peak in the wireline logs; the wireline logs instead show four peaks between 195 and 255 mbsf that do not have any obvious counterpart in the LWD logs. Finally, as noted earlier, the very low resistivities measured in the wireline logs at $\sim 100$ and 180 mbsf are likely to be the result of an enlarged hole.

\section{Logging units}

The logged section in Holes U1326A and U1326D can be divided into three logging units, based on obvious changes in the LWD and wireline gamma ray, density, electrical resistivity, and acoustic measurements (Figs. F50, F51, F52). These three logging units have no obvious correspondence to the lithostratigraphic units described in "Lithostratigraphy." We defined the depth intervals of the logging units mainly on the basis of the more complete suite of LWD logs acquired in Hole U1326A. As noted above, the wireline logs from Hole U1326D show similar horizons in a position that is shallower by $\sim 12 \mathrm{~m}$, 
and the depth intervals of the logging units need to be correspondingly adjusted in Hole U1326D.

Logging Unit 1 (0-72 mbsf in Hole U1326A) is characterized by a resistivity trend that steadily increases from $\sim 1 \Omega \mathrm{m}$ near the seafloor to $\sim 1.5 \Omega \mathrm{m}$ at the bottom of the unit. This increase in resistivity with depth is matched by an increase in density (from 1.7 $\mathrm{g} / \mathrm{cm}^{3}$ near the seafloor to $2 \mathrm{~g} / \mathrm{cm}^{3}$ at $120 \mathrm{mbsf}$ ) and a decrease in porosity (from $70 \%$ near the seafloor to $50 \%$ at $120 \mathrm{mbsf}$ ). This unit shows only a few small resistivity peaks (e.g., at $\sim 52$ and 60 mbsf in the LWD logs; Fig. F50) that may be attributed to gas hydrate.

Logging Unit 2 (72-240 mbsf in Hole U1326A; 60228 mbsf in Hole U1326D) is characterized by uniform density and porosity trends, with values around $2 \mathrm{~g} / \mathrm{cm}^{3}$ and $45 \%$, respectively. Resistivity shows a prominent high at 72-107 mbsf in Hole U1326A, with peaks above $40 \Omega \mathrm{m}$. This interval of high resistivity displays a number of alternating, thin intervals of very high and low resistivity, spanning the range $2-40 \Omega \mathrm{m}$. These thin intervals are especially well defined between 77 and 90 mbsf (Fig. F50). These high and low resistivities are likely to correspond to alternating layers with high and low gas hydrate concentrations, respectively. Below this high-resistivity interval at the top, the rest of Unit 2 (107-240 mbsf in Hole U1326A; 95-228 mbsf in Hole U1326D) has a constant background value of $\sim 1.5 \Omega \mathrm{m}$. The $P$-wave velocities $\left(V_{\mathrm{P}}\right)$ measured by wireline logging in Hole U1326D (Fig. F51) show highly variable values (between 1750 and $>3000 \mathrm{~m} /$ s) in the same interval (60-90 mbsf) where the wireline log resistivities reach high values and are variable. The high $V_{\mathrm{p}}$ values are consistent with high concentrations of gas hydrate, as pure gas hydrate has $V_{\mathrm{p}}$ values of $3800-4000 \mathrm{~m} / \mathrm{s}$ (e.g., Pearson et al., 1983). For the rest of this unit, $V_{\mathrm{p}}$ increases from $\sim 1700 \mathrm{~m} / \mathrm{s}$ below $90 \mathrm{mbsf}$ to $2000 \mathrm{~m} / \mathrm{s}$ at the bottom of Unit 2 (228 mbsf in Hole U1326D).

The top of logging Unit 3 (240-300 mbsf in Hole U1326A; 228-288 mbsf in Hole U1326D) shows a subtle increase in density, from $\sim 2 \mathrm{~g} / \mathrm{cm}^{3}$ at the top to $2.1 \mathrm{~g} / \mathrm{cm}^{3}$ at $255 \mathrm{mbsf}$, and remains constant to 300 mbsf. This density trend is matched by a corresponding decrease in porosity (from $40 \%$ at the top to $35 \%$ at $255 \mathrm{mbsf}$ ). The background resistivity also increases slightly and displays a clear peak that reaches $5 \Omega \mathrm{m}$ at 255-261 mbsf (Fig. F50). This resistivity peak could be caused by gas hydrate or free gas. Free gas seems more likely, as this interval is located below the projected BSR depth estimated from seismic reflection data (234 mbsf), and should be below the base of the GHSZ. On the other hand, $V_{\mathrm{p}}$ is at least $1700 \mathrm{~m} / \mathrm{s}$ in Unit 3 (Fig. F51), and there is no sign of the low velocities expected if free gas were present. The relatively high velocities observed could lead to an increase in the depth of the BSR estimated from reflection traveltimes.

\section{Logging-while-drilling borehole images}

The GeoVISION, ADNVISION, and EcoScope LWD tools generate high-resolution images of borehole log data. The ADNVISION and EcoScope tools produce images of density and hole radius (computed on the basis of the density correction, which depends on the borehole standoff). The GeoVISION tool produces a gamma ray image and shallow, medium, and deep depth of investigation resistivity images.

Figure F54 shows some of the LWD images collected by the EcoScope and GeoVISION tools. It should be noted that the display in Figure F54 is highly compressed in the vertical direction. The unwrapped images are $\sim 90 \mathrm{~cm}$ wide (for an 11 inch diameter borehole), and the vertical scale is compressed by a factor of $\sim 37: 1$. These high-resolution images can be used for detailed sedimentological and structural interpretations and to image gas hydrate distribution in sediments (e.g., in layers, nodules, or fractures). Gas hydrate-bearing sediments exhibit high resistivities within intervals of uniform or low bulk density. Layers with high resistivities and high densities are likely to be low-porosity, compacted, or carbonaterich sediments.

The images suggest that there may be high concentrations of gas hydrate in thin layers between 81 and 100 mbsf in Hole U1326A, where densities are generally low and high-resistivity, gas hydrate-rich layers (bright in the resistivity images of Fig. F54) alternate with low-resistivity layers (dark in the images of Fig. F54) that are likely to contain little or no gas hydrate. The images also clearly show a number of hole enlargements, which are imaged as dark bands in Figure F54 at depths of 110, 206, and 225 mbsf. These are the same washouts detected by the LWD ultrasonic caliper (Fig. F49).

When the images are examined with less vertical exaggeration than in Figure F54, they clearly show that the layers identified in Hole U1326A are dipping to the north-northeast with dips between $45^{\circ}$ and $85^{\circ}$ (Fig. F55). This is in agreement with the west-northwest-east-southeast strike of the uplifted ridge where Hole U1326A was drilled and with evidence for landward-dipping reflectors in seismic profiles. It should be pointed out that reflections on the seismic profiles across this ridge show dips of $15^{\circ}$ or less, but seismic reflection data cannot image steeply dipping structures. Also, the observation of steep dips in Hole U1326A should be interpreted carefully. In a complex tectonic structure (e.g., a faulted anticline or a 
stack of imbricated thrust sheets) the dips measured along a vertical line may vary significantly over short horizontal distances, and their interpretation can be variable (for examples of structural interpretation of dips from borehole images, see Luthi, 2001).

\section{Logging porosities}

Sediment porosities can be determined from analyses of recovered cores and from downhole measurements (see "Physical properties" and "Downhole logging," both in the "Methods" chapter). Data from the LWD density and neutron logs from Hole U1326A were used to calculate sediment porosities. Core-derived physical property data, including porosities (see "Physical properties"), were used to both calibrate and evaluate the log-derived sediment porosities.

The LWD log-derived density measurements were used to calculate sediment porosities $(\phi)$ using the standard density-porosity relation

$$
\phi=\left(\rho_{g}-\rho_{b}\right) /\left(\rho_{g}-\rho_{w}\right) .
$$

We used a constant water density $\left(\rho_{\mathrm{w}}\right)$ of $1.03 \mathrm{~g} / \mathrm{cm}^{3}$ and a grain/matrix density $\left(\rho_{\mathrm{g}}\right)$ of $2.76 \mathrm{~g} / \mathrm{cm}^{3}$, which is the average grain density measured in core samples (see "Physical properties"). The density logderived porosities range from $\sim 60 \%$ near the seafloor to $\sim 40 \%$ at $300 \mathrm{mbsf}$ (Fig. F56). In several intervals (e.g., 10-20, 105-110, and 205-210 mbsf) hole enlargements resulted in an erroneously low value of density, and corresponding porosity values that are too high.

The LWD neutron porosity log from Hole U1326A (Fig. F56) yielded sediment porosities ranging from an average value of $\sim 70 \%$ near the seafloor to $\sim 50 \%$ at 350 mbsf. As noted earlier, porosities measured by the neutron log are expected to be higher than those computed from the density log in clay-rich sediments because the neutron log essentially measures hydrogen abundance, and hydrogen in clay minerals is counted as porosity. The EcoScope neutron porosity shown in Figure F56 is the "best thermal neutron porosity," which has been corrected for the effect of clay, so that it is only slightly higher than the density porosity. Like the density porosity, the neutron porosity log also gives values that are too high where the hole is enlarged.

The comparison of core- and LWD-derived porosities in Figure F56 shows good agreement throughout the logged interval, with the density porosities being slightly lower and the neutron porosities slightly higher than the core porosities.

\section{Gas hydrate and free gas occurrence}

As previously discussed (see "Downhole logging" in the "Methods" chapter) the presence of gas hydrate is generally characterized by increases in electrical resistivity and acoustic velocity that are not accompanied by a corresponding decrease in porosity. A decrease in porosity alone in a water-saturated sediment can result in an increase in resistivity and acoustic velocity. Resistivity logging data from Holes U1326A and U1326D show a number of positive resistivity anomalies without a corresponding decrease in porosity (Figs. F50, F51), suggesting that there are several intervals where gas hydrate may be present.

\section{Water saturation from Archie's equation}

To estimate the amount of gas hydrate at Site U1326, we used the Archie relation (e.g., Collett and Ladd, 2000)

$$
S_{\mathrm{w}}=\left[\left(a \times R_{\mathrm{w}}\right) /\left(\phi^{m} \times R_{\mathrm{t}}\right)\right]^{1 / n},
$$

where

$$
\begin{aligned}
S_{\mathrm{w}}= & \text { water saturation, } \\
a & =\text { tortuosity coefficient, } \\
R_{\mathrm{w}}= & \text { formation water resistivity, } \\
\phi= & \text { density porosity computed from the ADNVI- } \\
& \text { SION enhanced resolution bulk density, } \\
m= & \text { cementation coefficient, } \\
R_{\mathrm{t}}= & \text { GeoVISION high-resolution button deep av- } \\
& \text { erage resistivity, and } \\
n= & \text { saturation coefficient. }
\end{aligned}
$$

We use the button deep resistivity instead of the ring resistivity because the button deep resistivity matches the resistivities with the greatest depth of investigation measured by the EcoScope tool (except for having a higher resolution), whereas the ring resistivity is generally lower than the EcoScope deep resistivities.

Gas hydrate saturation $\left(S_{\mathrm{h}}\right)$ is the percentage of pore space in sediment that is occupied by gas hydrate, which is the complement of the water saturation $S_{\mathrm{w}}$ :

$$
S_{h}=1-S_{w}
$$

The procedure followed to estimate $S_{w}$ with Archie's relation is illustrated in Figure F57. We first computed porosity from the density $\log$ as described above with a water density $\rho_{w}$ of $1.03 \mathrm{~g} / \mathrm{cm}^{3}$ and a grain/matrix density $\rho_{\mathrm{g}}$ of $2.76 \mathrm{~g} / \mathrm{cm}^{3}$ (see "Physical properties").

To estimate the formation water resistivity $\left(R_{\mathrm{w}}\right)$, we started by constructing a salinity versus depth function based on IW salinity measurements (see "Interstitial water geochemistry"). This salinity versus depth function simply consists of a constant value of 34 . At every logging depth, we combined the salinity value with a formation temperature obtained from the geothermal gradient estimated from the downhole formation temperature measurements (see "In situ temperature profile") and used the formulas of 
Fofonoff (1985) to obtain the corresponding value of the water resistivity $R_{\mathrm{w}}$.

To estimate the water saturation $S_{\mathrm{w}}$ we also need to choose values for the Archie coefficients $a$ and $m$. One way to do this is to choose a logged interval where the sediments can be assumed to be water saturated and to fit $a$ and $m$ to a plot of measured resistivity versus porosity, known as a "Pickett plot" (e.g., Doveton, 1994). In marine sediments, however, the range of porosity is relatively small and it is not possible to obtain a robust estimate of both $a$ and $m$. We prefer to set $a=1$, which is physically the most realistic value because it gives a resistivity equal to the formation water resistivity when the porosity is $100 \%$. We then compute an "estimated $m$ " coefficient by

$$
m_{\text {est }}=-\log (F) / \log (f),
$$

where $F=\left(R_{\mathrm{t}} / R_{\mathrm{w}}\right)$ is the formation factor. This $m_{\text {est }}$ curve should give the appropriate value to be used in Archie's equation in water-saturated intervals and will give anomalously high values in intervals that contain hydrocarbons. A reasonable value of $m=2.5$ can be chosen from the baseline trend of the $m$ curve shown in Figure F57.

The next step is to compute the resistivity $R_{0}$ predicted by Archie's equation for a water-saturated formation of a given porosity, which is given by

$$
R_{0}=\left(a \times R_{\mathrm{w}}\right) / \phi^{m} \text {. }
$$

Using Archie coefficients of $a=1$ and $m=2.5$, we computed an $R_{0}$ curve that generally follows the measured resistivity $R_{\mathrm{t}}$, but is significantly lower than $R_{\mathrm{t}}$ in several intervals, mostly in logging Unit 2 (Fig. F57). Finally, we computed the water saturation $S_{\mathrm{w}}$ using a saturation coefficient $n=2$.

As noted earlier, several hole enlargements resulted in logging density values that are erroneously low and approach water density. In the Archie interpretation, these low densities translate into artificially high porosities, low values for the predicted watersaturated resistivity $R_{0}$, and low values of water saturation $S_{\mathrm{w}}$. These anomalous intervals should be ignored and are marked by gray overlays in Figure F57.

Figure F57 shows a clear interval between 60 and 100 mbsf where the measured resistivity $R_{\mathrm{t}}$ generally exceeds the resistivity $R_{0}$ predicted for water-saturated conditions, and where the inferred water saturations can be as low as $\sim 20 \%$. This interval encompasses the bottom of logging Unit 1 and the top of Unit 2, and the high-resolution LWD porosity and resistivity logs used in Figure F57 show that it is very heterogeneous, being composed of many alternating layers of highly variable porosity and resistivity. We interpret the 60-100 mbsf interval as a sequence of thin, sandy, gas hydrate-rich layers intercalated with clayrich layers that may contain little or no gas hydrate. This interpretation is in general agreement with the pore water freshening observed in sand layers at Site U1326 (see the pore water salinity data in Fig. F57 and "Interstitial water geochemistry").

\section{Comparison with infrared images}

The IR core images taken on the catwalk measure the core liner temperature, and cold anomalies in the IR images caused by gas hydrate dissociation give an independent "map" of gas hydrate concentrations (see "Physical properties"). Figure F58 shows a comparison of the LWD and wireline resistivity logs with the IR images. Some of the IR cold temperature anomalies correlate with layers of high resistivity. For example, the IR images show a thin cold interval centered at 247 mbsf that corresponds to a high-resistivity peak $(\sim 3 \Omega \mathrm{m})$ in the wireline logs). Other cold intervals in the IR images are harder to correlate to highresistivity peaks in the wireline logs because of incomplete core recovery. The correlation between the IR images (taken on cores from Holes U1326C and U1326D) and the LWD logs (Hole U1326A) needs to be done with care because the dip of the sedimentary structure noted earlier will require a depth shift.

\section{References}

Aldred, W., Cook, J., Bern, P., Carpenter, B., Hutchinson, M., Lovell, J., Rezmer-Cooper, I., and Leder, P.C., 1998. Using downhole annular pressure measurements to improve drilling performance. Oilfield Rev., 10(4):40-55.

Collett, T.S., and Ladd, J., 2000. Detection of gas hydrate with downhole logs and assessment of gas hydrate concentrations (saturations) and gas volumes on the Blake Ridge with electrical resistivity log data. In Paull, C.K., Matsumoto, R., Wallace, P.J., and Dillon, W.P. (Eds.), Proc. ODP, Sci. Results, 164 [Online]. Available from World Wide Web: http://www-odp.tamu.edu/publications/164_SR/chap_19/chap_19.htm.

Collett, T.S., Riedel, M., Malone, M.J., and the Expedition 311 Project Team, 2005. Cascadia margin hydrates. IODP Sci. Prosp., 311. doi:10.2204/iodp.sp.311.2005

Davis, E.E., Currie, R.G., and Sawyer, B.S., 1987. Marine geophysical maps of western Canada: regional SeaMARC II acoustic image mosaics and Sea Beam bathymetry. Geol. Surv. Can., Maps 2-1987 through 171987 (scale 1:250,000).

Davis, E.E., Hyndman, R.D., and Villinger, H., 1990. Rates of fluid expulsion across the northern Cascadia accretionary prism: constraints from new heat flow and multichannel seismic reflection data. J. Geophys. Res., 95:8869-8889.

Doveton, J.H., 1994. Geologic log analysis using computer methods. AAPG Comp. Appl. Geol., 2:169. 
Fofonoff, N.P., 1985. Physical properties of seawater: a new salinity scale and equation of state for seawater. J. Geophys. Res., 90:3332-3342.

Hyndman, R.D., and Davis, E.E., 1992. A mechanism for the formation of methane hydrate and seafloor bottomsimulating reflectors by vertical fluid expulsion. J. Geophys. Res., 97:7025-7041.

Hyndman, R.D., and Wang, K., 1993. Thermal constraints on the zone of major thrust earthquake failure: the Cascadia subduction zone. J. Geophys. Res., 98:2039-2060.

Luthi, S.M., 2001. Geological Well Logs: Their Use in Reservoir Modeling: Berlin (Springer-Verlag).

Pearson, C.F., Halleck, P.M., McGuire, P.L., Hermes, R., and Mathews, M., 1983. Natural gas hydrate deposits: a review of in-situ properties. J. Phys. Chem., 87:41804185 .
Pimmel, A., and Claypool, G., 2001. Introduction to shipboard organic geochemistry on the JOIDES Resolution. ODP Tech. Note, 30 [Online]. Available from World Wide Web: http://www-odp.tamu.edu/publications/ tnotes/tn30/INDEX.HTM.

Sloan, E.D., 1998. Clathrate Hydrates of Natural Gases (2nd ed.): New York (Marcel Dekker).

$\mathrm{Xu}, \mathrm{W} ., 2002$. Phase balance and dynamic equilibrium during formation and dissociation of methane gas hydrate. Fourth Int. Conf. Gas Hydrates, 19023:199-200.

$\mathrm{Xu}, \mathrm{W} ., 2004$. Modeling dynamic marine gas hydrate systems. Am. Mineral., 89:1271-1279.

Publication: 28 October 2006

MS 311-104 
Figure F1. Location of site survey data around Site U1326 (proposed Site CAS-03C; Collett et al., 2005). Shown are positions of common depth points (CDPs) of multichannel seismic (MCS) data and shot points of single channel seismic (SCS) data. Axes are Universal Transverse Mercator (UTM) projection easting and northing coordinates using the WGS-84 reference.

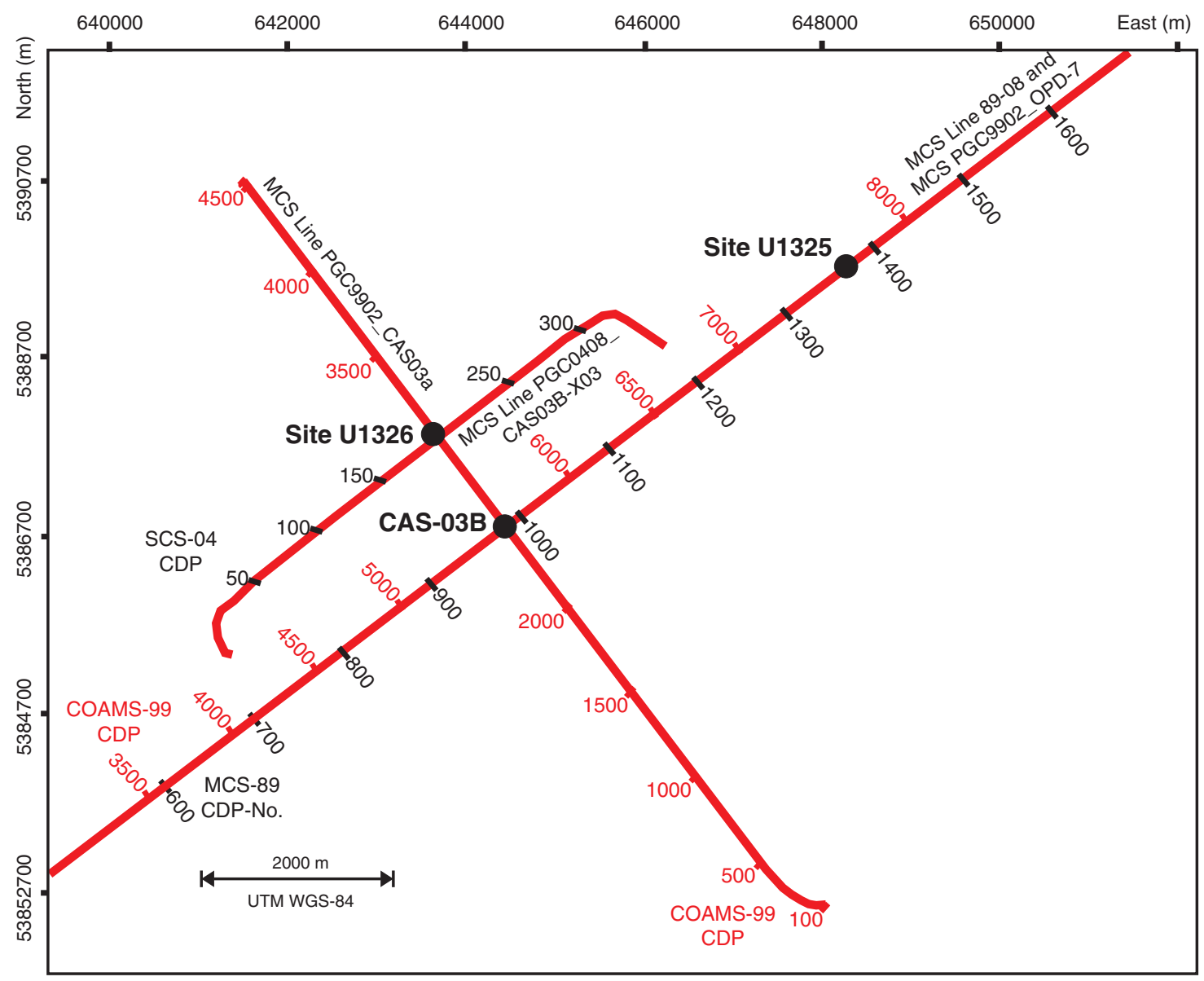




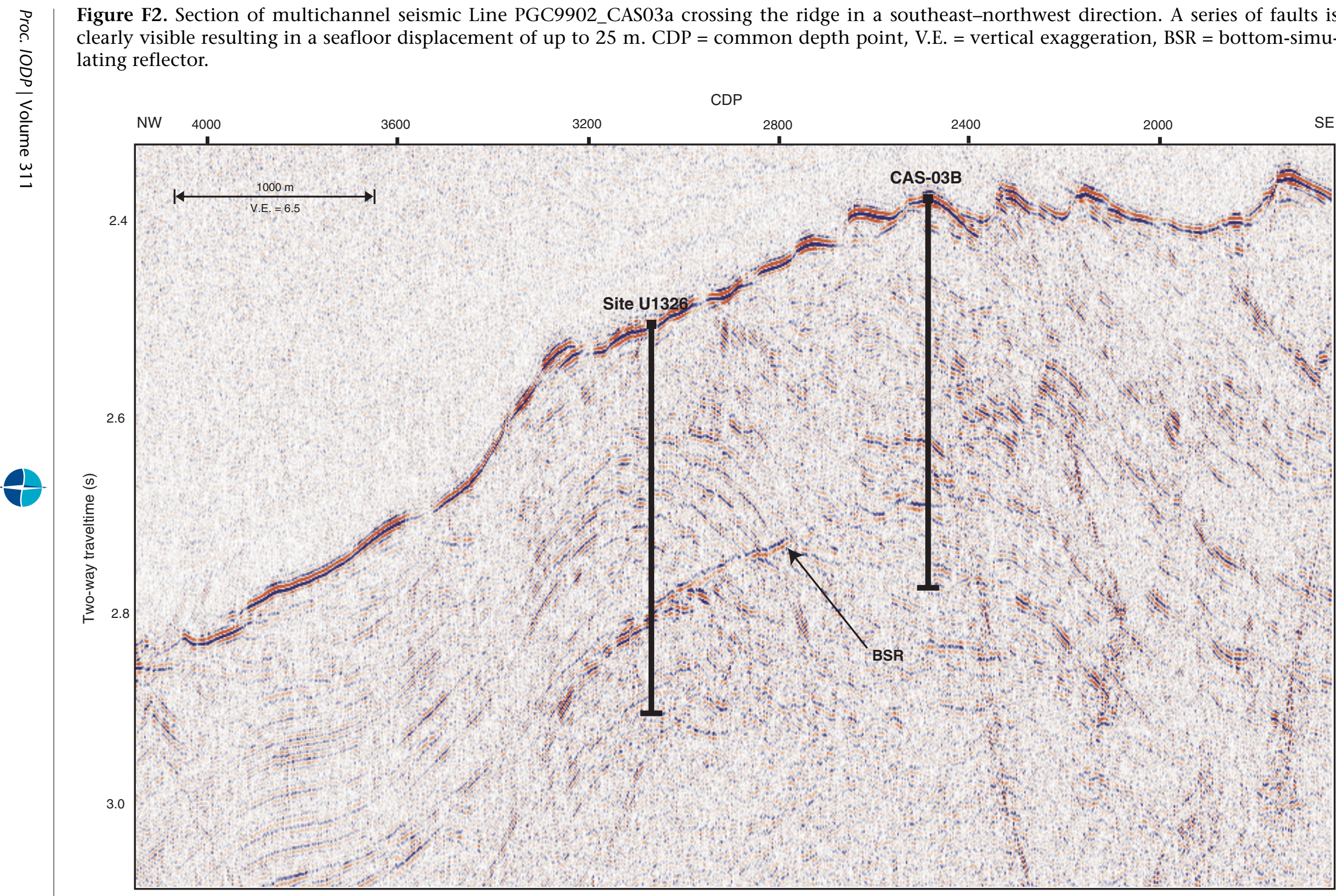


Figure F3. Section of multichannel seismic Line 89-08 crossing the ridge in a southwest-northeast direction. A bottom-simulating reflector (BSR) is prominent underneath the center of the ridge. The reflectivity of the ridge is asymmetric and may reflect changes in internal deformation. $\mathrm{CDP}=$ common depth point, V.E. = vertical exaggeration.

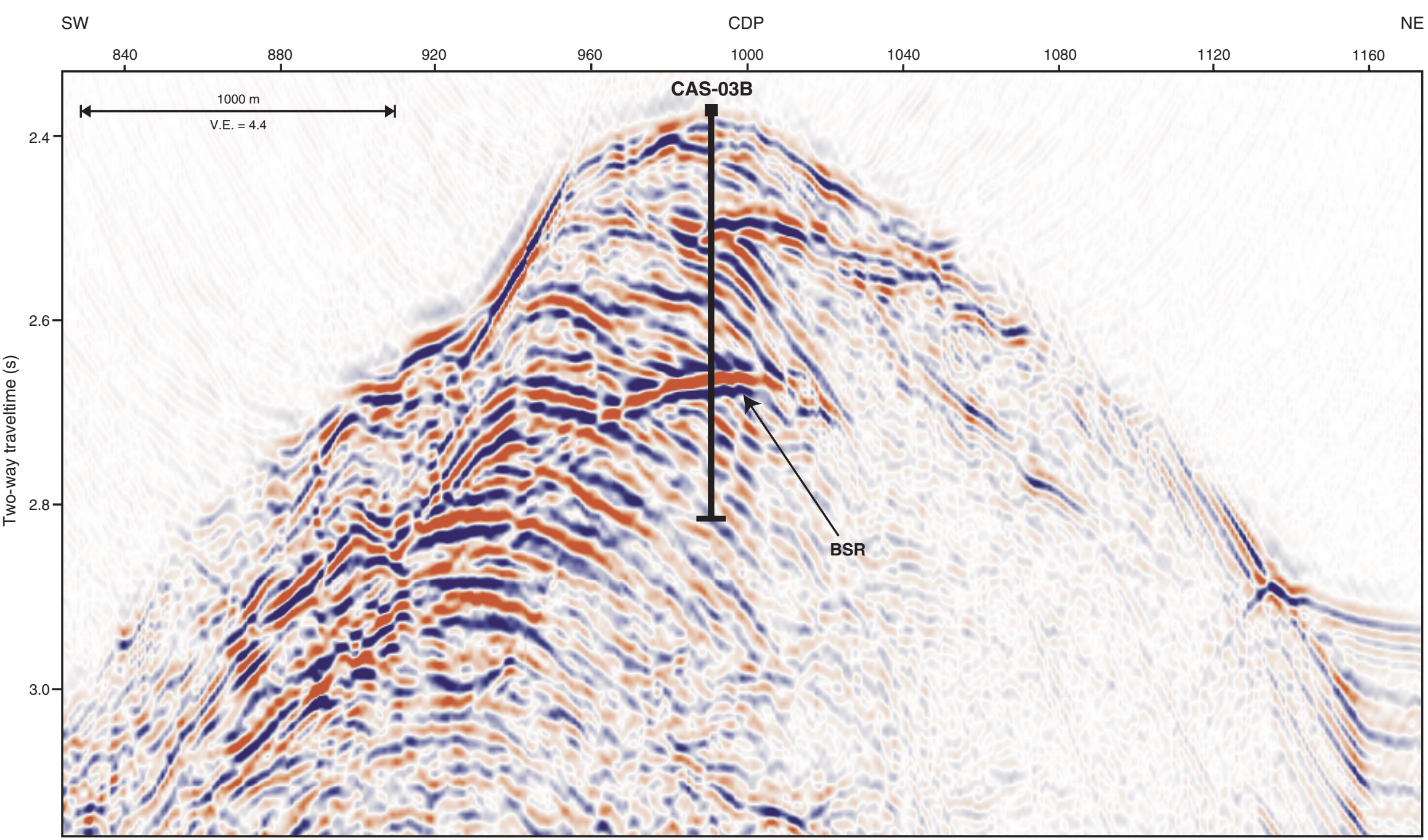


Figure F4. Section of multichannel seismic (MCS) Line PGC9902_ODP-7, identical in location to MCS Line 89-08, crossing the ridge in a southwest-northeast direction. The bottom-simulating reflector (BSR) is less strongly pronounced compared to MCS Line 89-08 and a similar difference in reflectivity pattern between the southwest and northeast flank of the ridge is observed. CDP $=$ common depth point, V.E. $=$ vertical exaggeration.

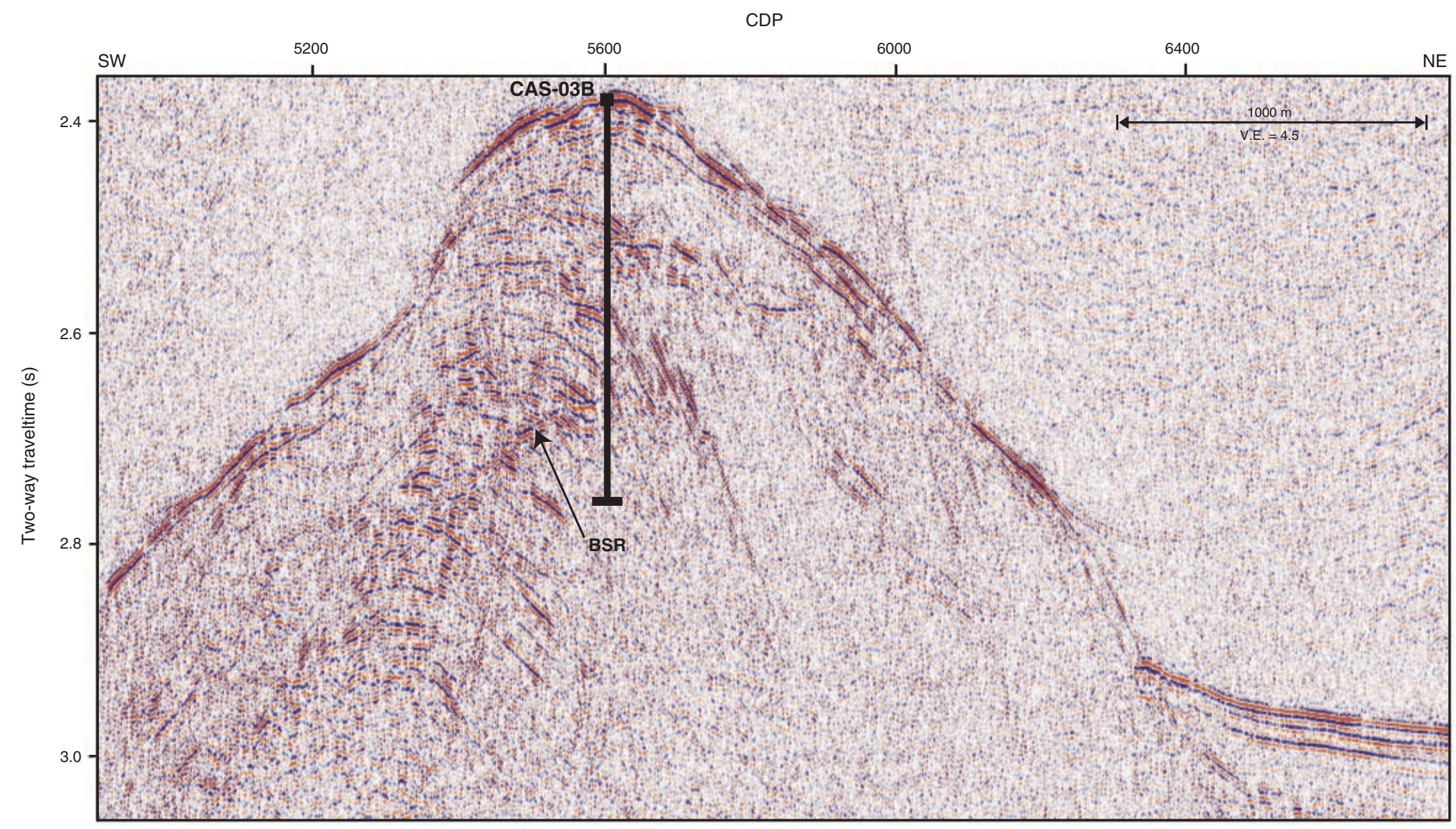


Figure F5. Section of singlechannel seismic Line PGC0408_CAS03B_X03 crossing over Site U1326. BSR = bottom-simulating reflector, CDP = common depth point.

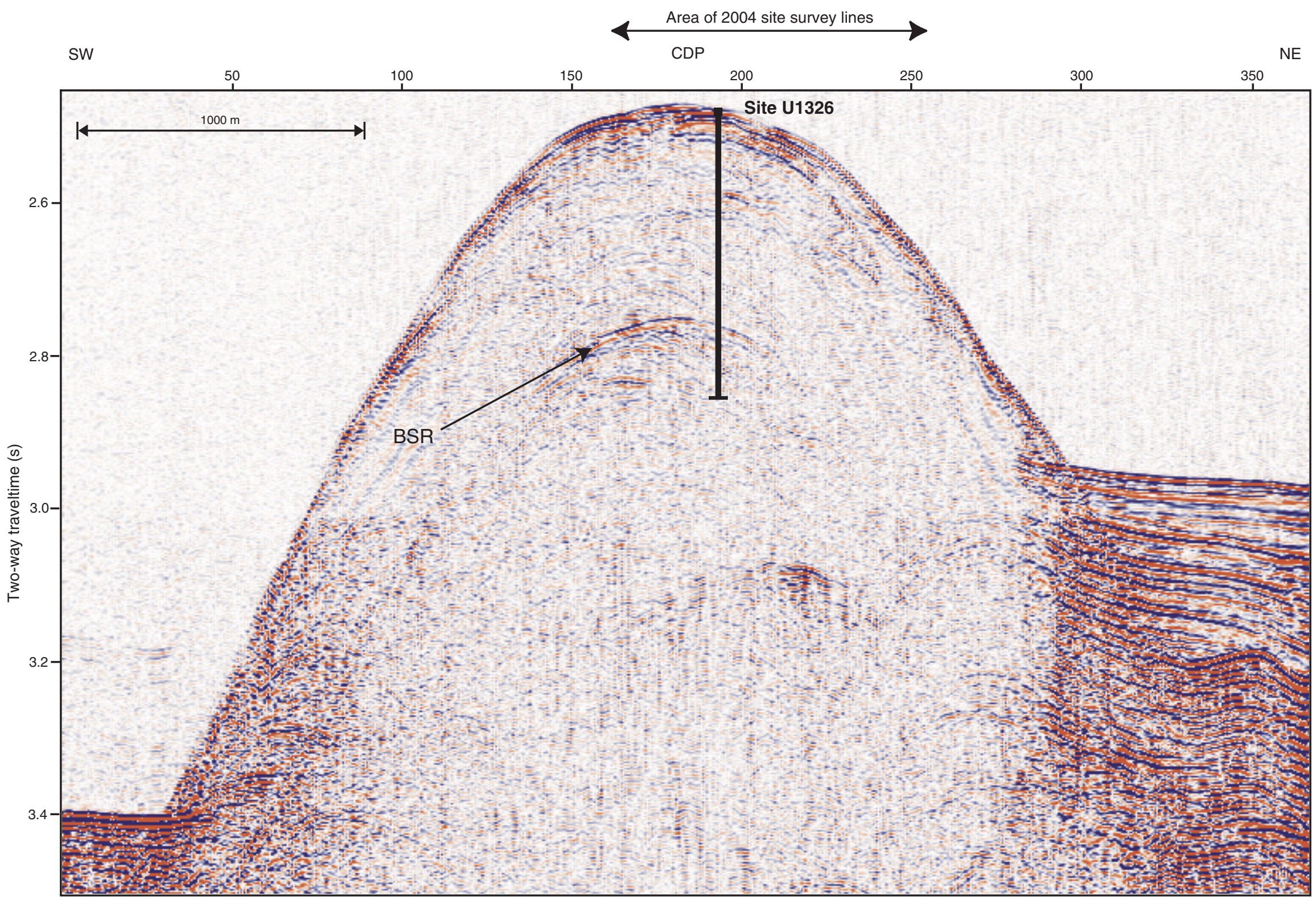


Figure F6. Location of holes drilled at Site U1326, showing track lines with seismic survey shot points. Axes are universal transverse Mercator (UTM) projection easting and northing coordinates using the WGS-84 reference.

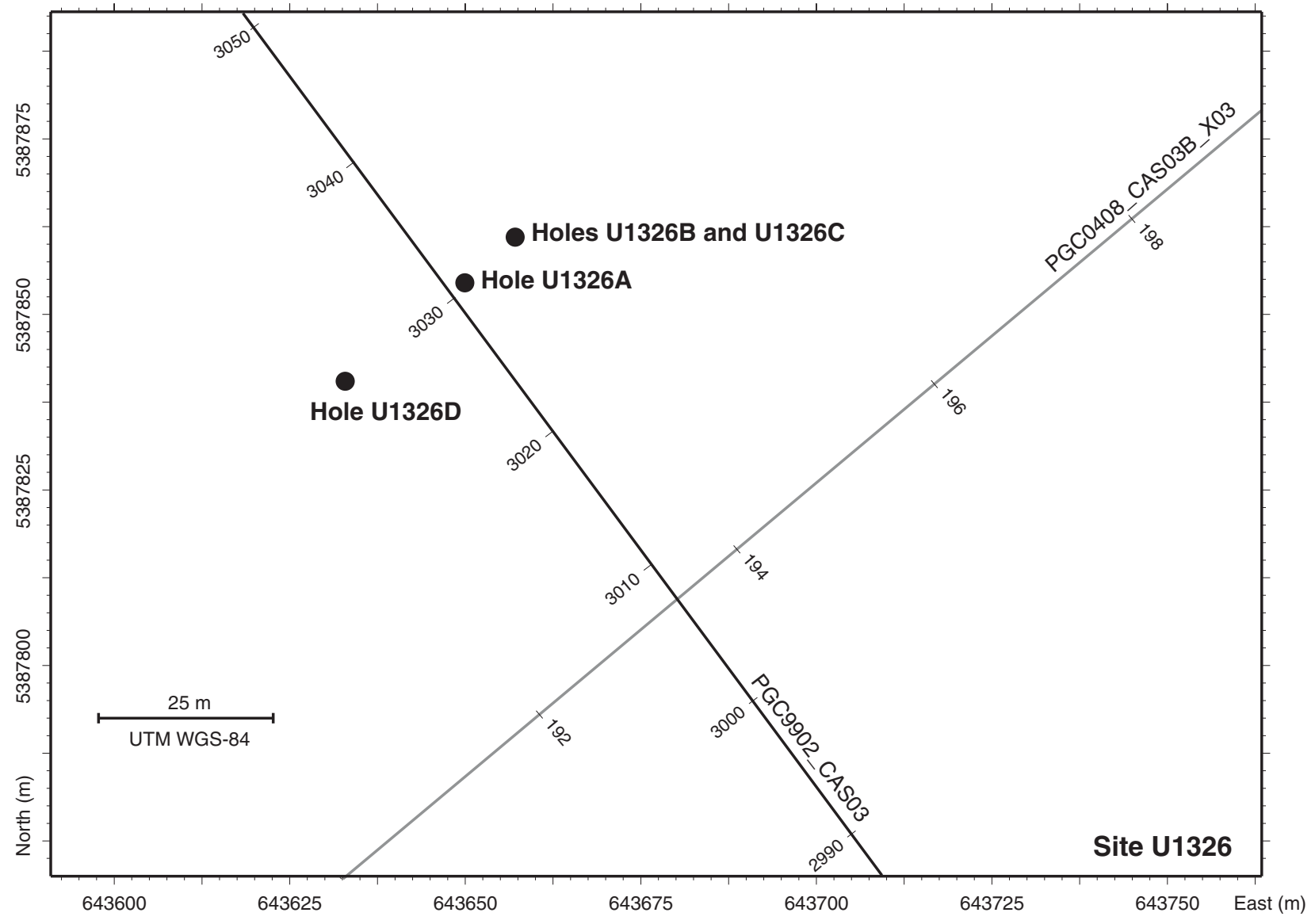


Figure F7. Lithostratigraphic summary for Holes U1326C (solid circles) and U1326D (open squares) showing the percentage of clay, silt, sand, biogenic opal (diatoms, radiolarians, siliceous spicules, silicoflagellates), foraminifers, and nannofossils in the major lithology; clay, silt, and sand in the minor lithology; and AMST color reflectance $\left(\mathrm{a}^{*}\right)$.
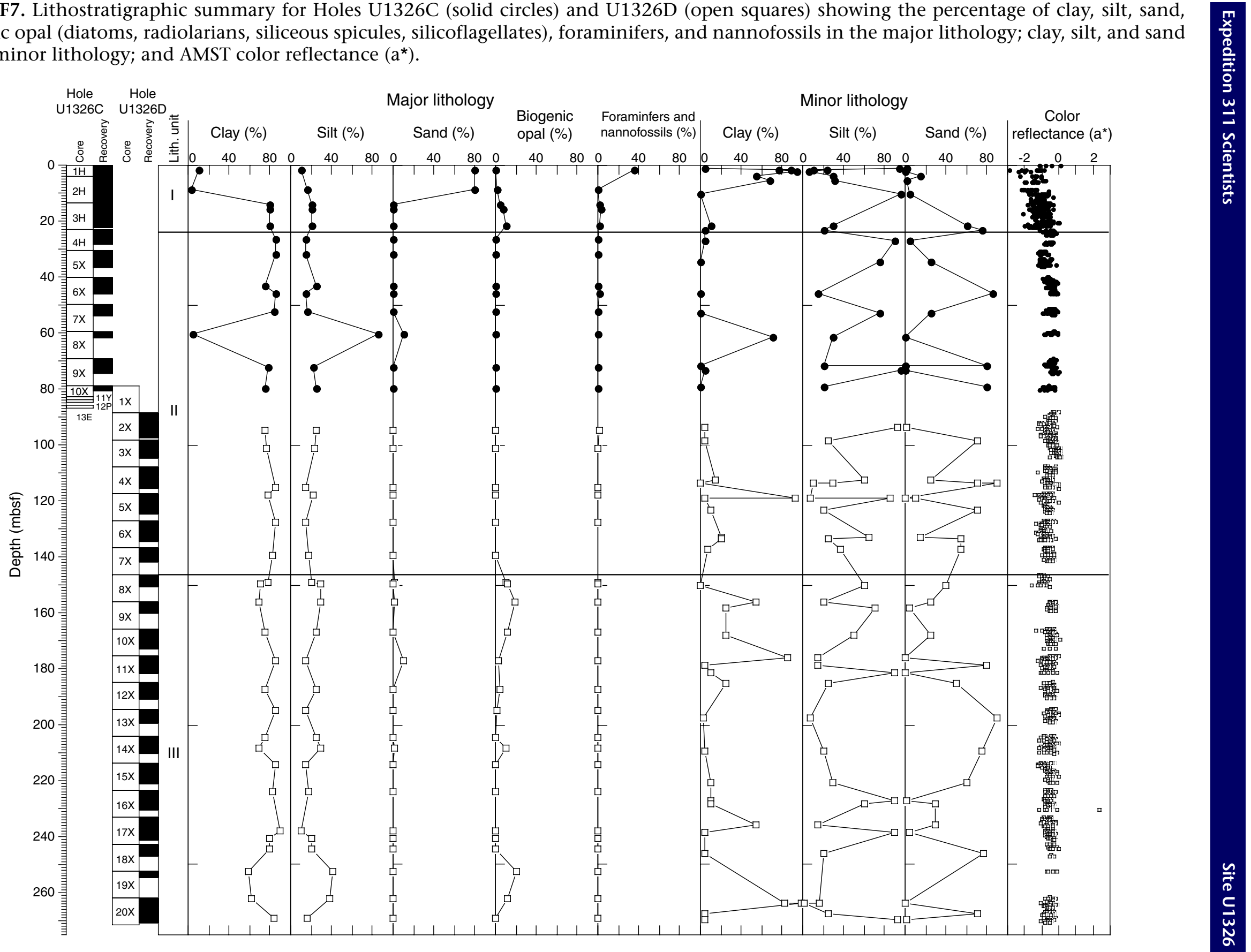
Figure F8. Dipping silty clay showing gradual color changes from dark greenish gray to dark gray in lithostratigraphic Unit I (interval 311-U1326C-3H-3, 80-110 cm). The greenish intervals have more abundant diatoms (as much as 10\%).

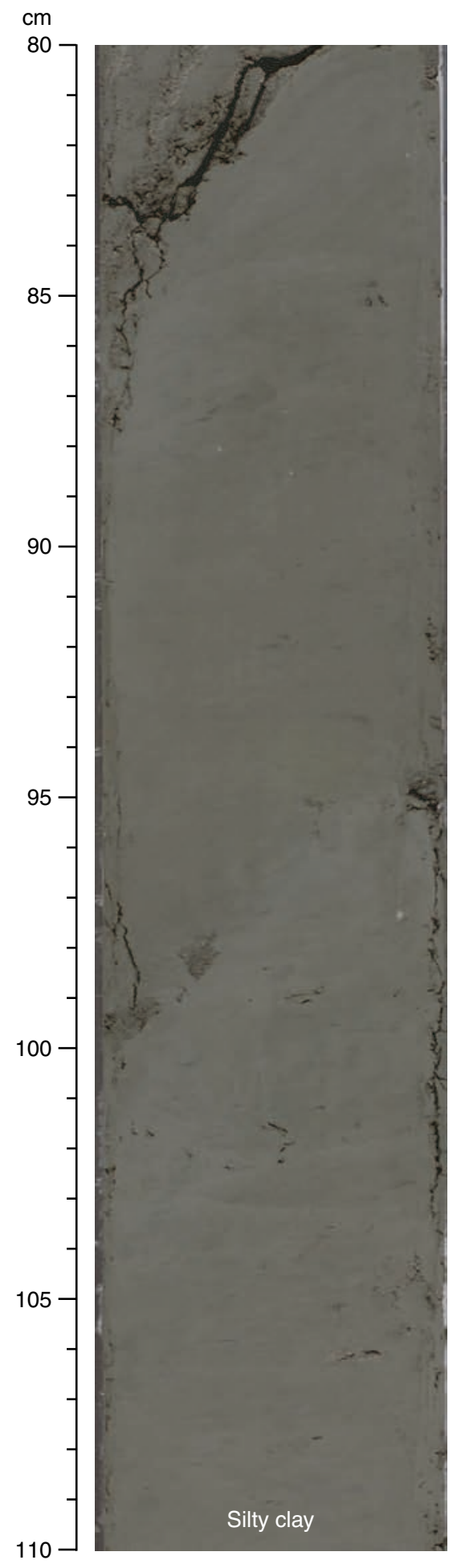


Figure F9. Dark gray silty clay with several evenly spaced, dipping dark gray sand layers and lenses in lithostratigraphic Unit I (interval 311-U1326C-2H-2, 0-32 cm).

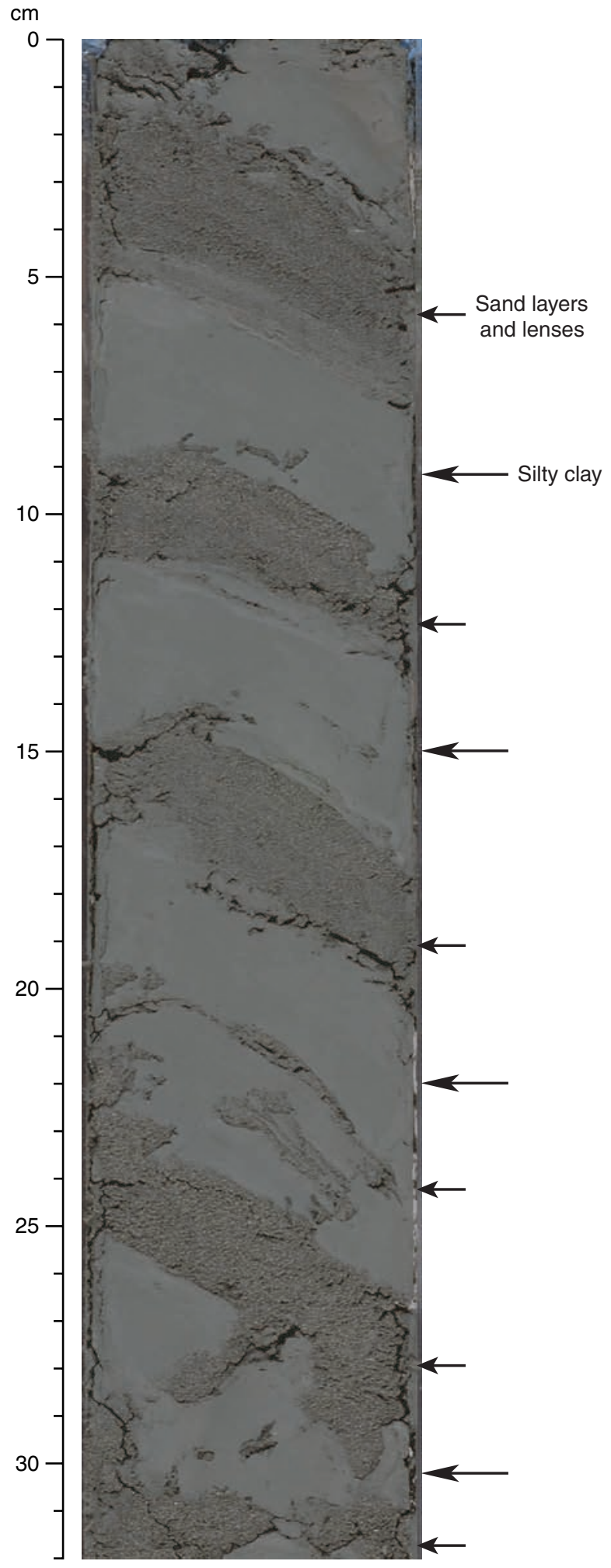


Figure F10. Bivalve shell fragments in lithostratigraphic Unit I (interval 311-U1326C-1H-2, 65-80 cm).

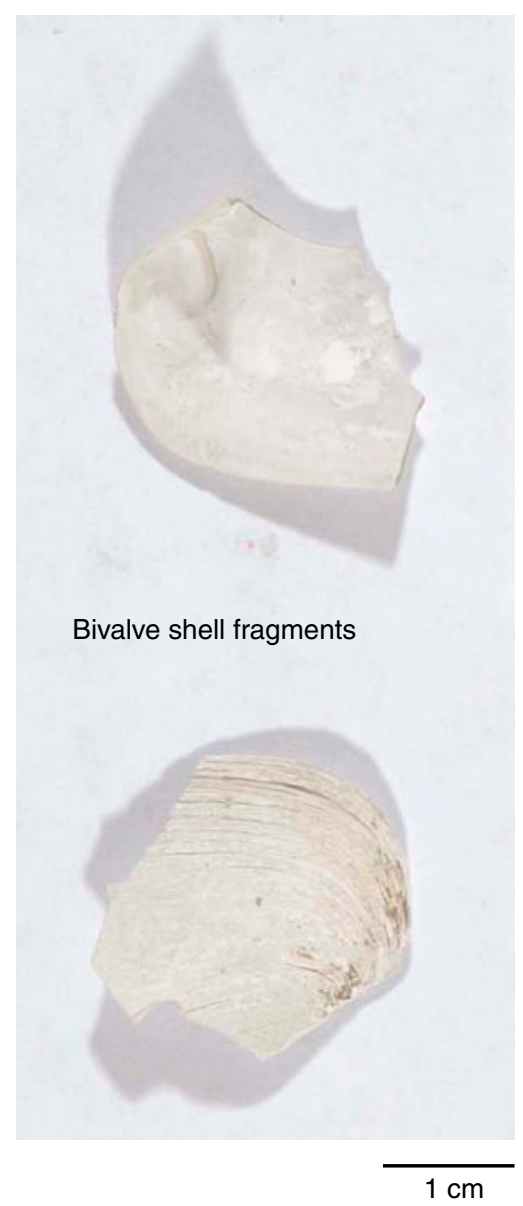


Figure F11. Unlithified carbonate cement and a lithified piece of carbonate composed of nonstoichiometric dolomite $\left(46 \mathrm{~mol} \% \mathrm{MgCO}_{3}\right.$ ) within very dark gray sand and dark gray clay in lithostratigraphic Unit I (interval 311-U1326B-1H-1, 90-106 cm).

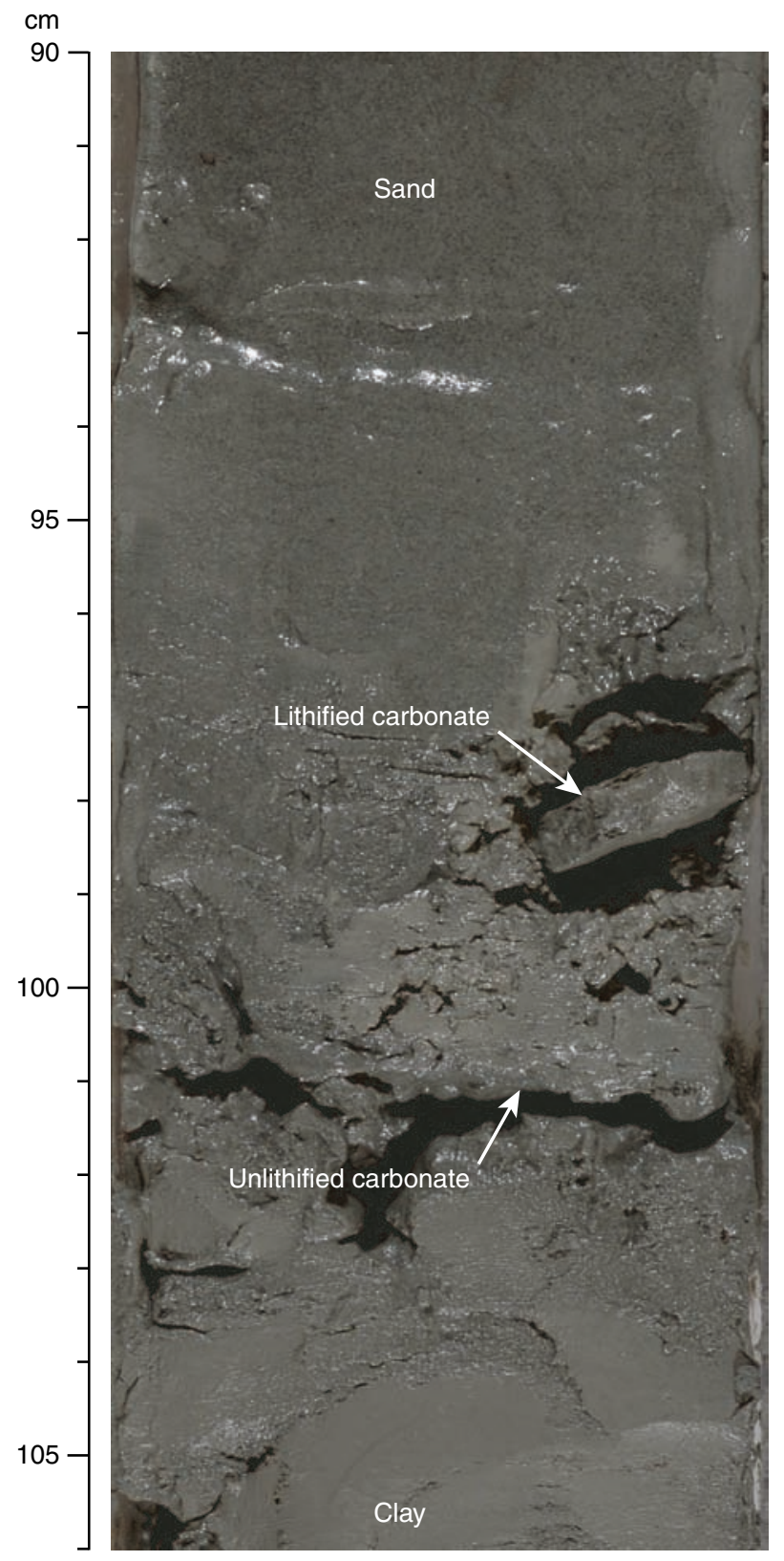


Figure F12. Unlithified microcrystalline carbonate cement in lithostratigraphic Unit I showing elongated crystals with lengths averaging 4-5 $\mu \mathrm{m}$ (Sample 311-U1326B-1H-1, $150 \mathrm{~cm}$ ).

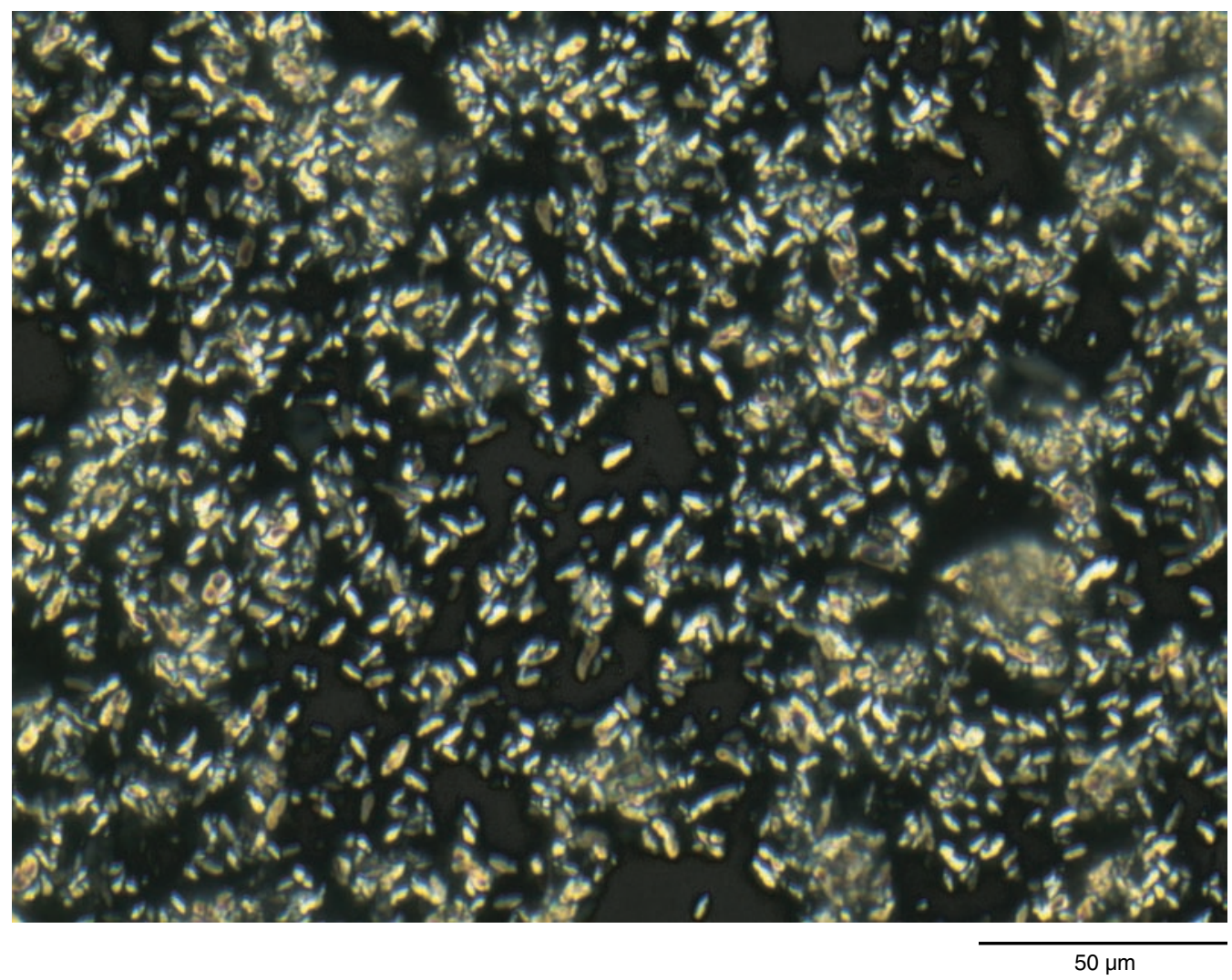


Figure F13. General occurrences of interbedded clay and silt (arrows) in lithostratigraphic Unit II (interval 311-U1326C-4H-3, 104-136 cm).

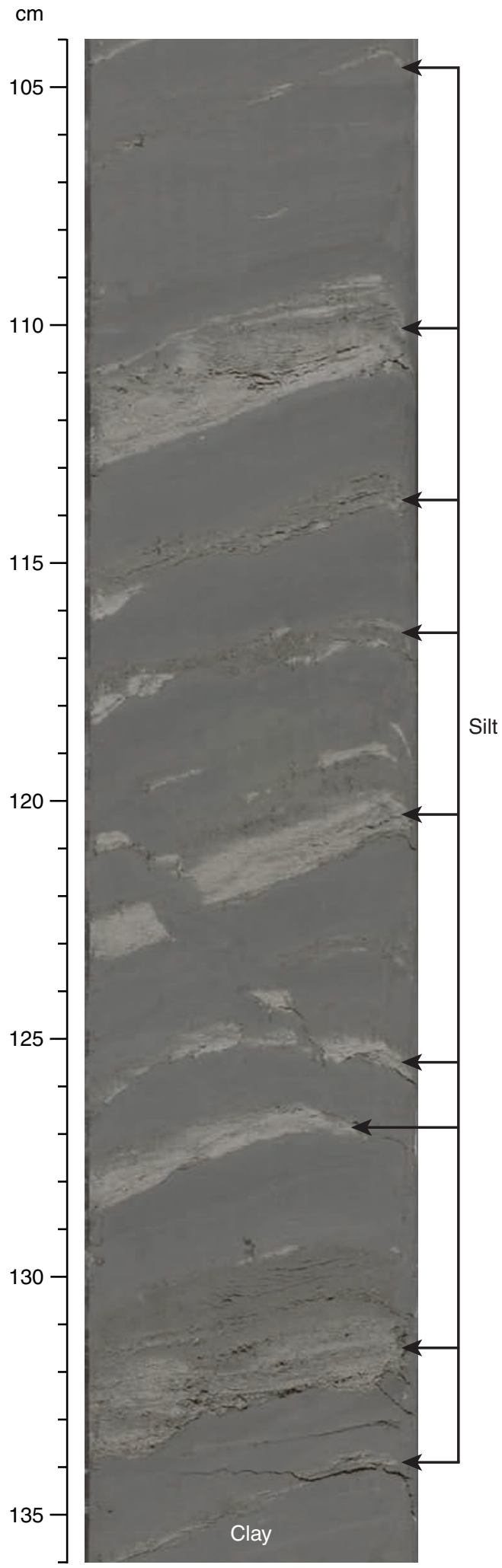


Figure F14. Dropstones and sand patches within dark gray clay in lithostratigraphic Unit II (interval 311U1326D-4X-5, 22-46 cm).

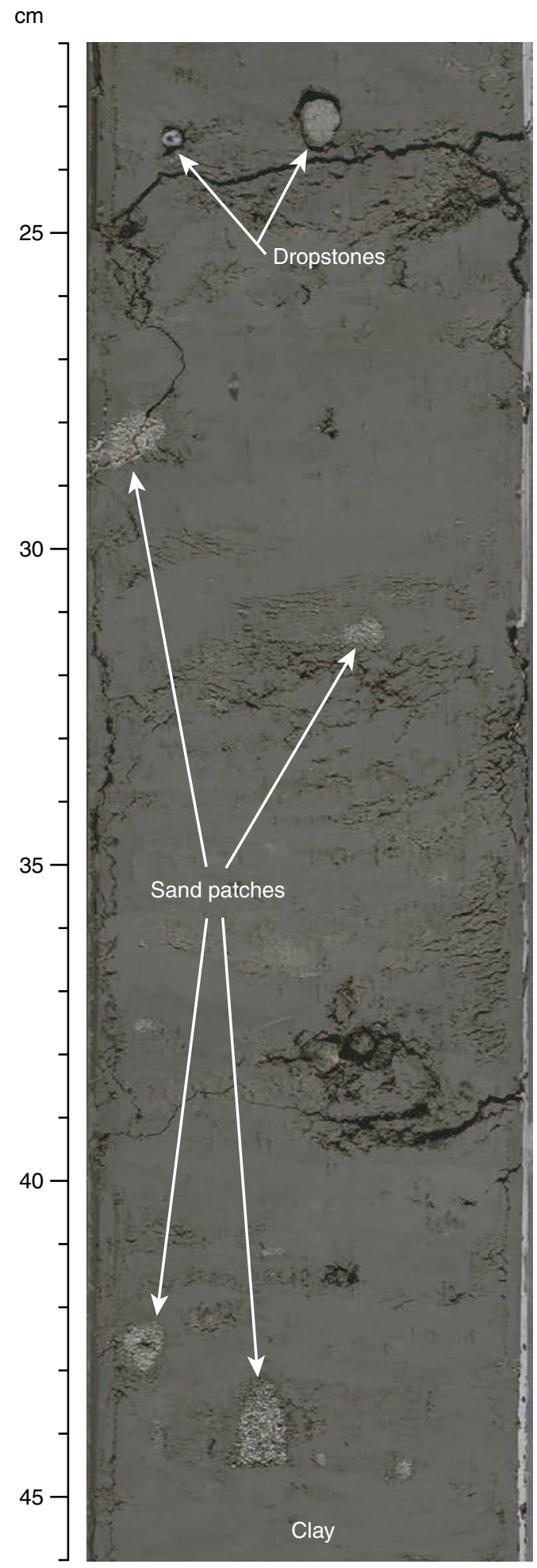


Figure F15. Unlithified carbonate cement within dark gray clay in lithostratigraphic Unit II (interval 311U1326D-5X-2, 0-15 cm).

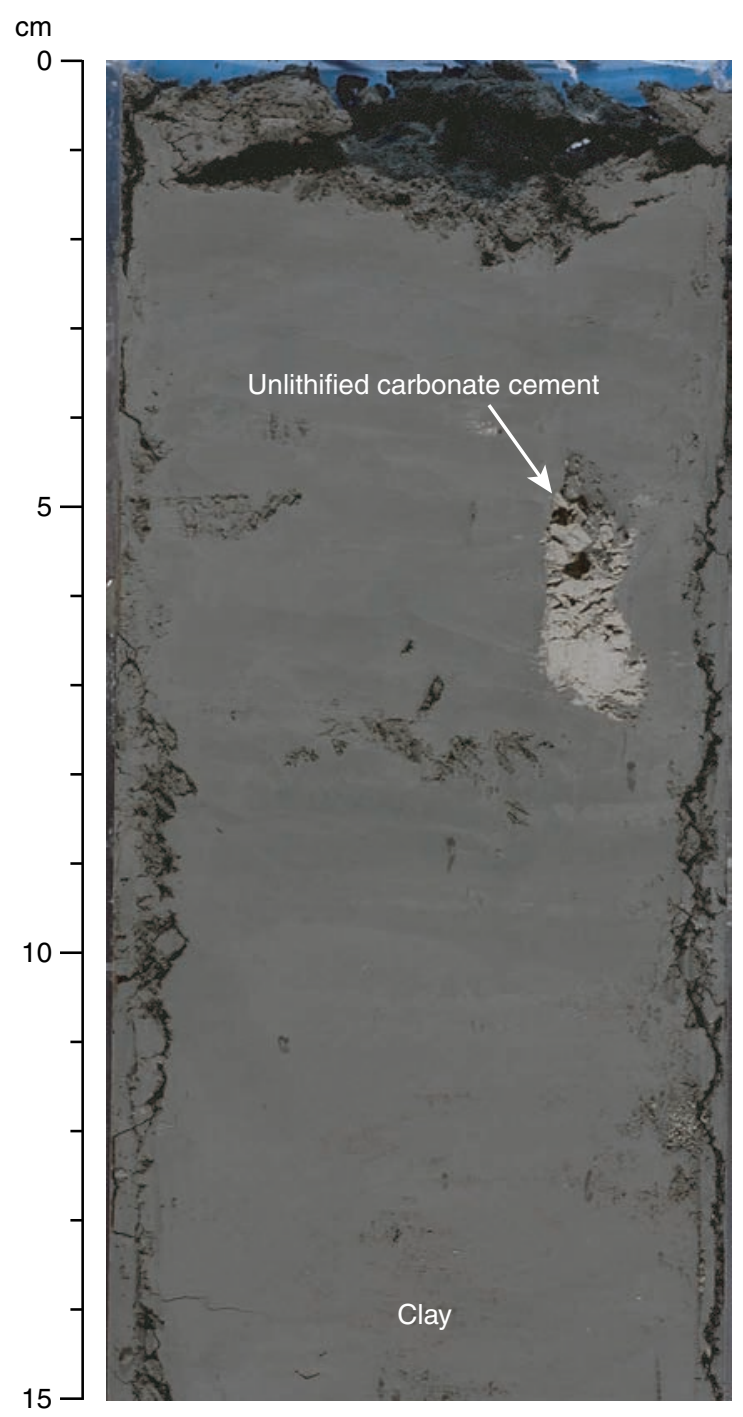


Figure F16. Soft-sediment deformation and a normal fault (arrows) cutting silt layers in lithostratigraphic Unit II (interval 311-U1326C-6X-5, 16-35 cm).

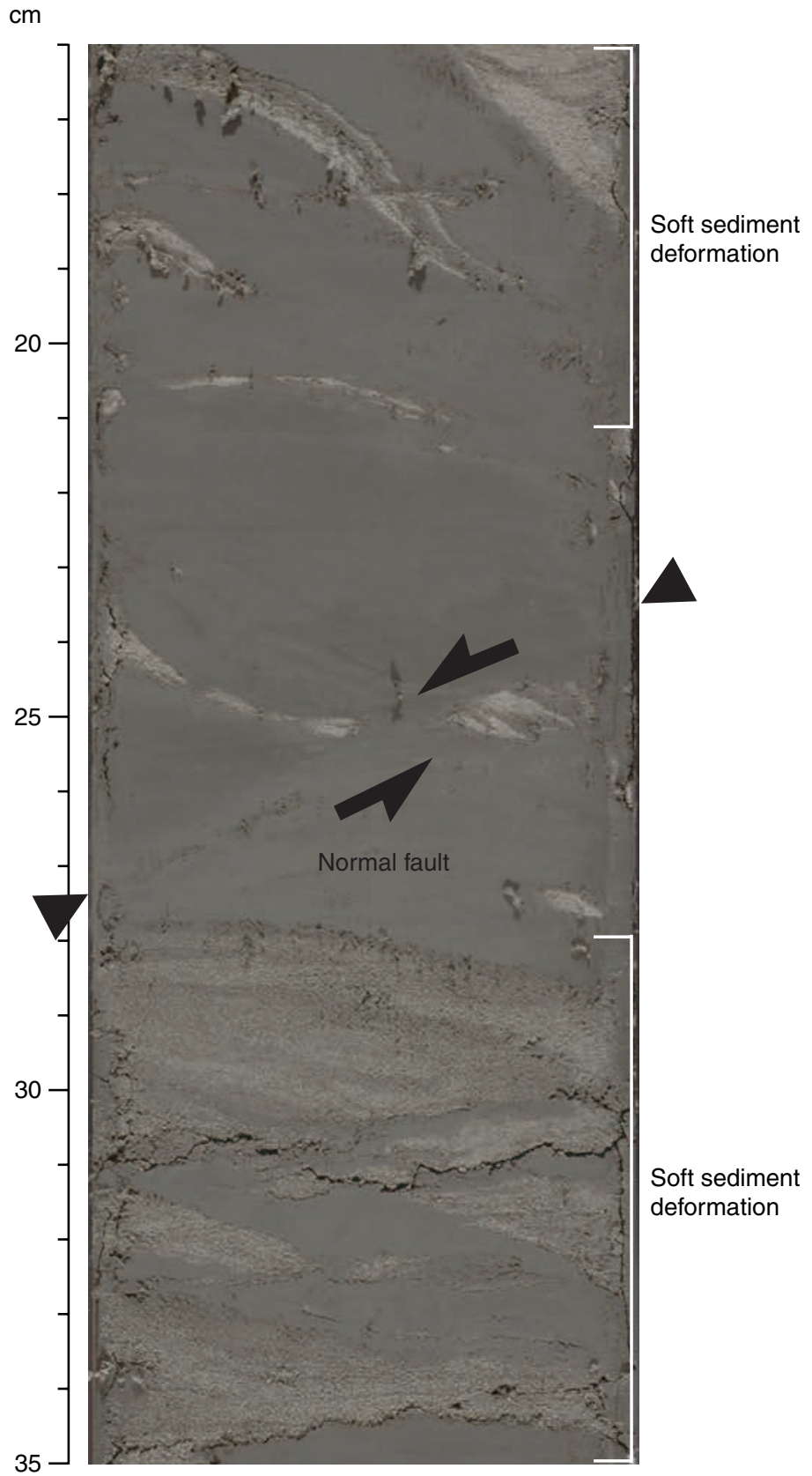


Figure F17. Thick, very dark gray sand layer within dark gray clay in lithostratigraphic Unit III (interval 311U1326D-13X-3, 2-23 cm).

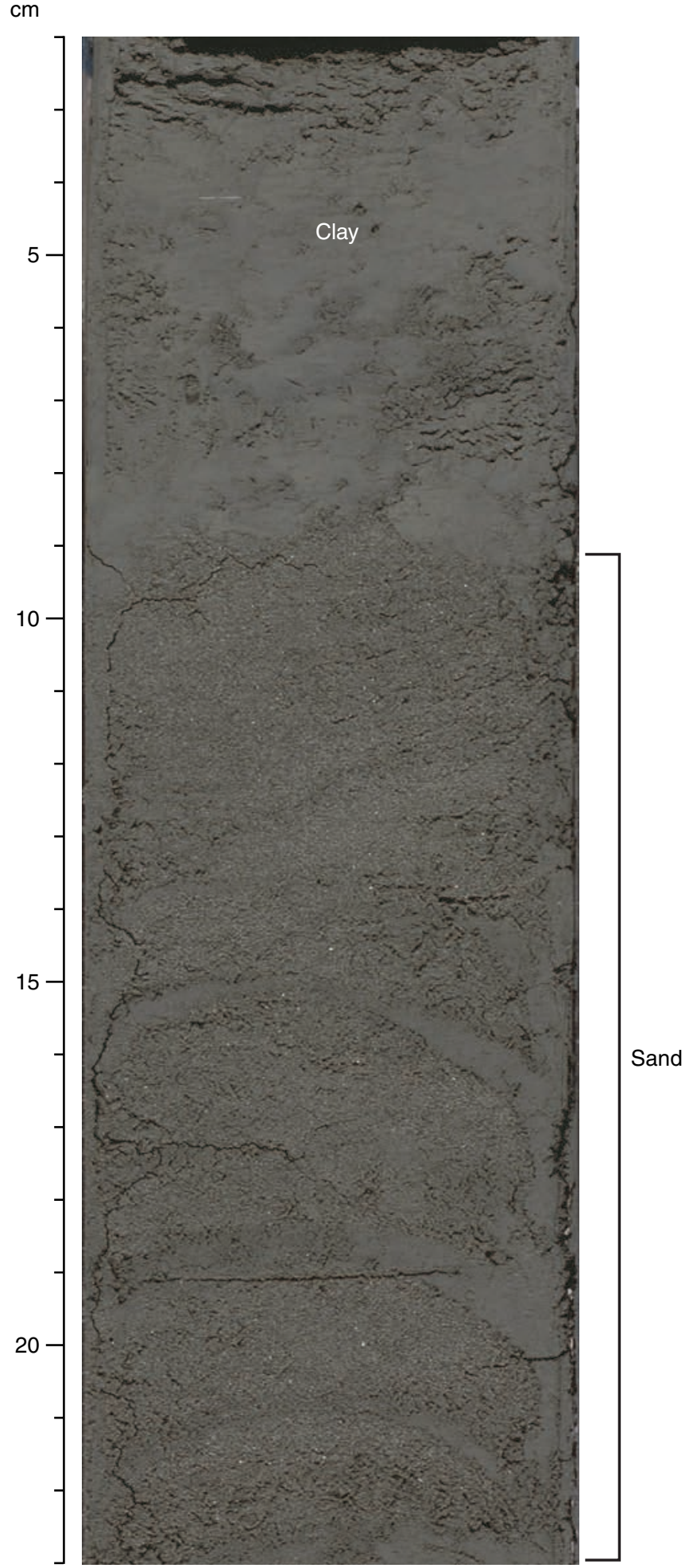


Figure F18. Partly lithified carbonates in silty clay with diatoms in lithostratigraphic Unit III (interval 311U1326D-9X-1, 0-30 cm).

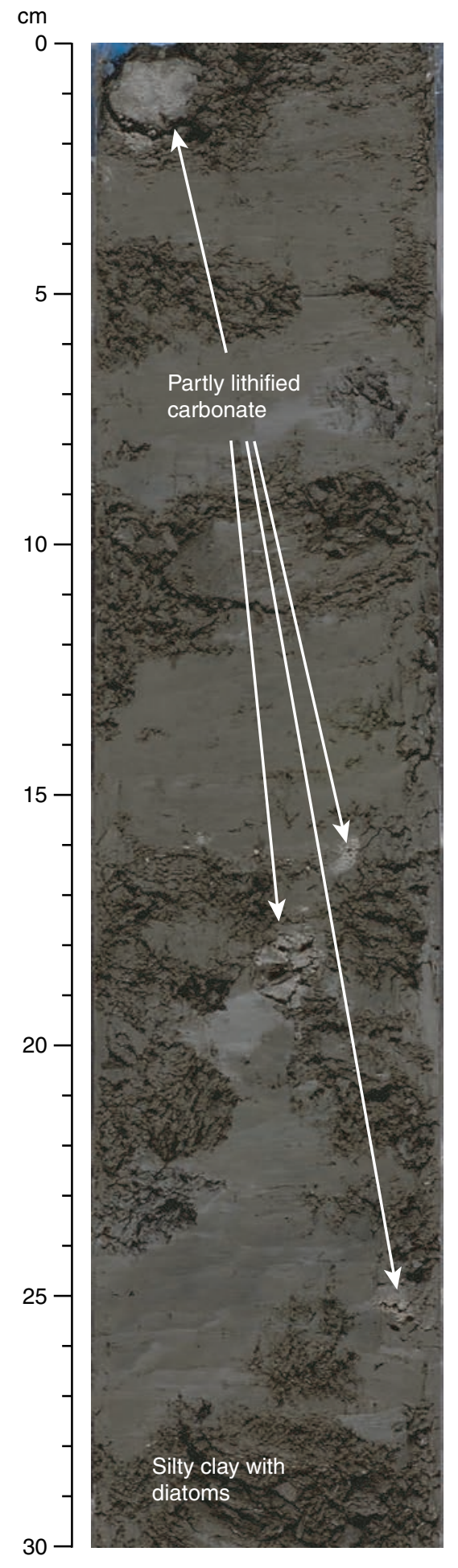


Figure F19. Soupy and mousselike sediment textures in lithostratigraphic Unit III (interval 311-U1326D-17X$1,10-35 \mathrm{~cm})$. Because the close-up photograph was taken one day after the core was split, the sediment has already dried significantly. The soupy texture between 18 and $26 \mathrm{~cm}$ is not clearly visible any more.

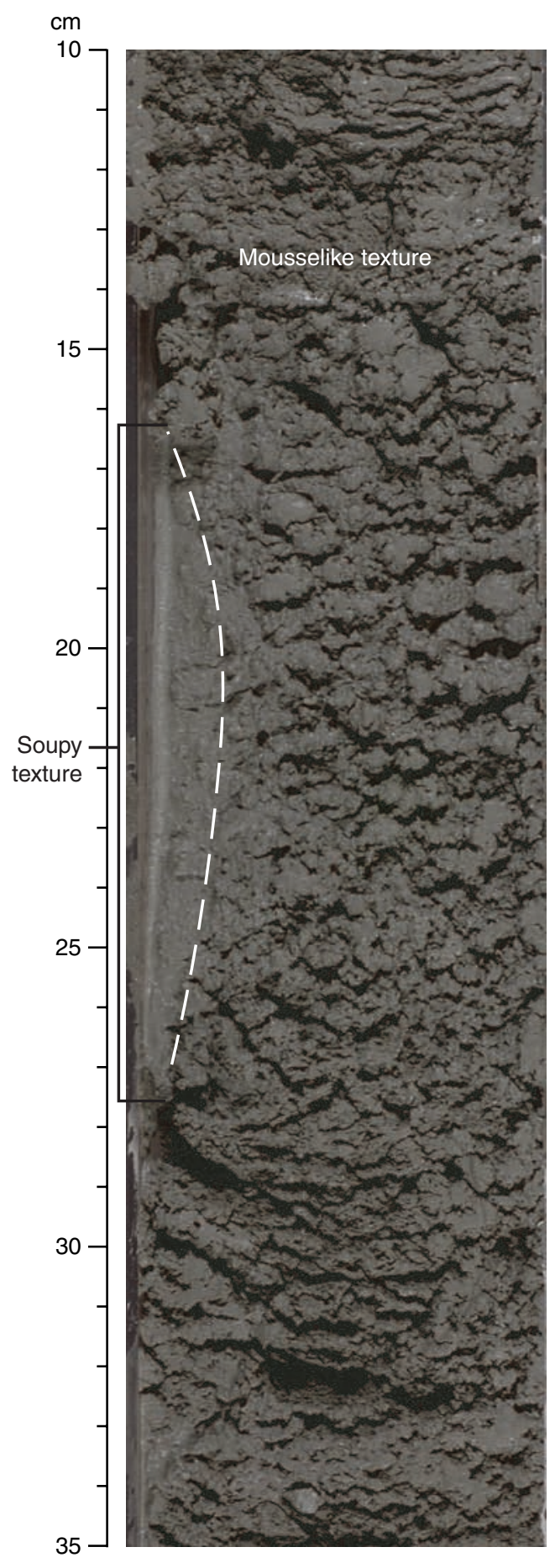


Figure F20. Mousselike sediment texture in lithostratigraphic Unit III (interval 311-U1326D-16X-3, 115-137 $\mathrm{cm})$.

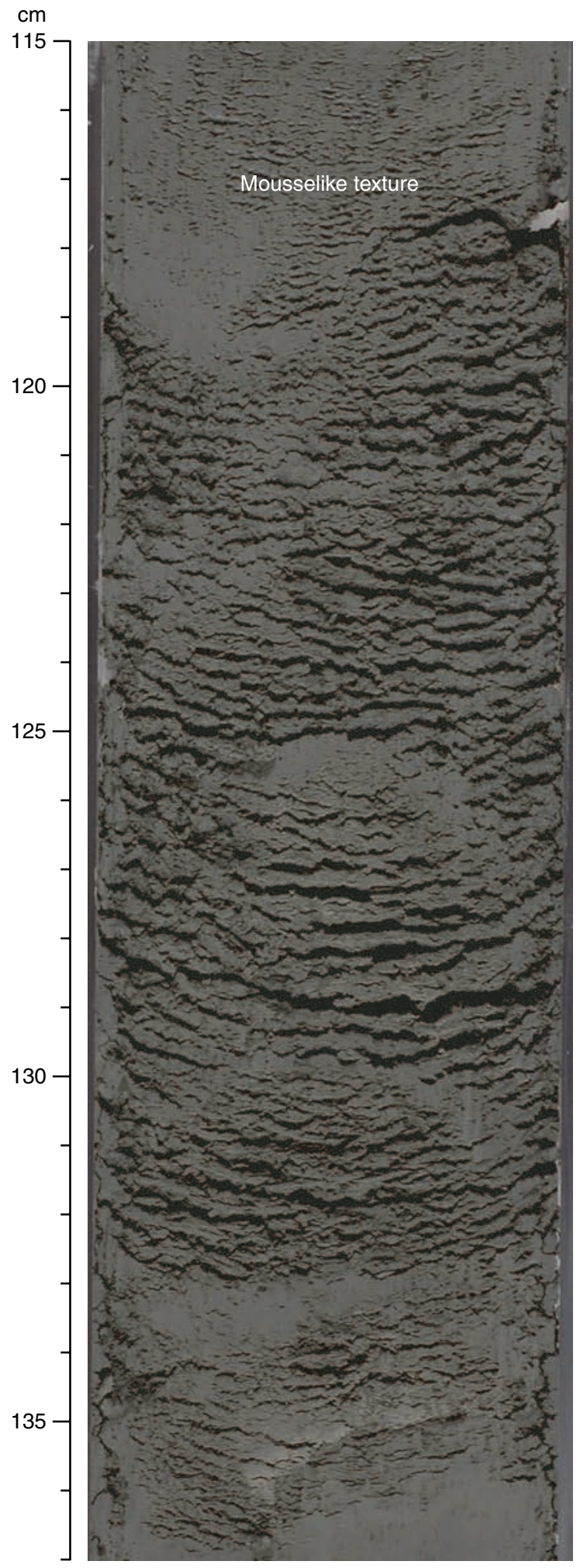


Figure F21. Concentration vs. depth profiles of salinity, chloride, sodium, and potassium in interstitial waters from Holes U1326C (red circles) and U1326D (green squares). SW = seawater, BSR = seismically inferred bottom-simulating reflector.
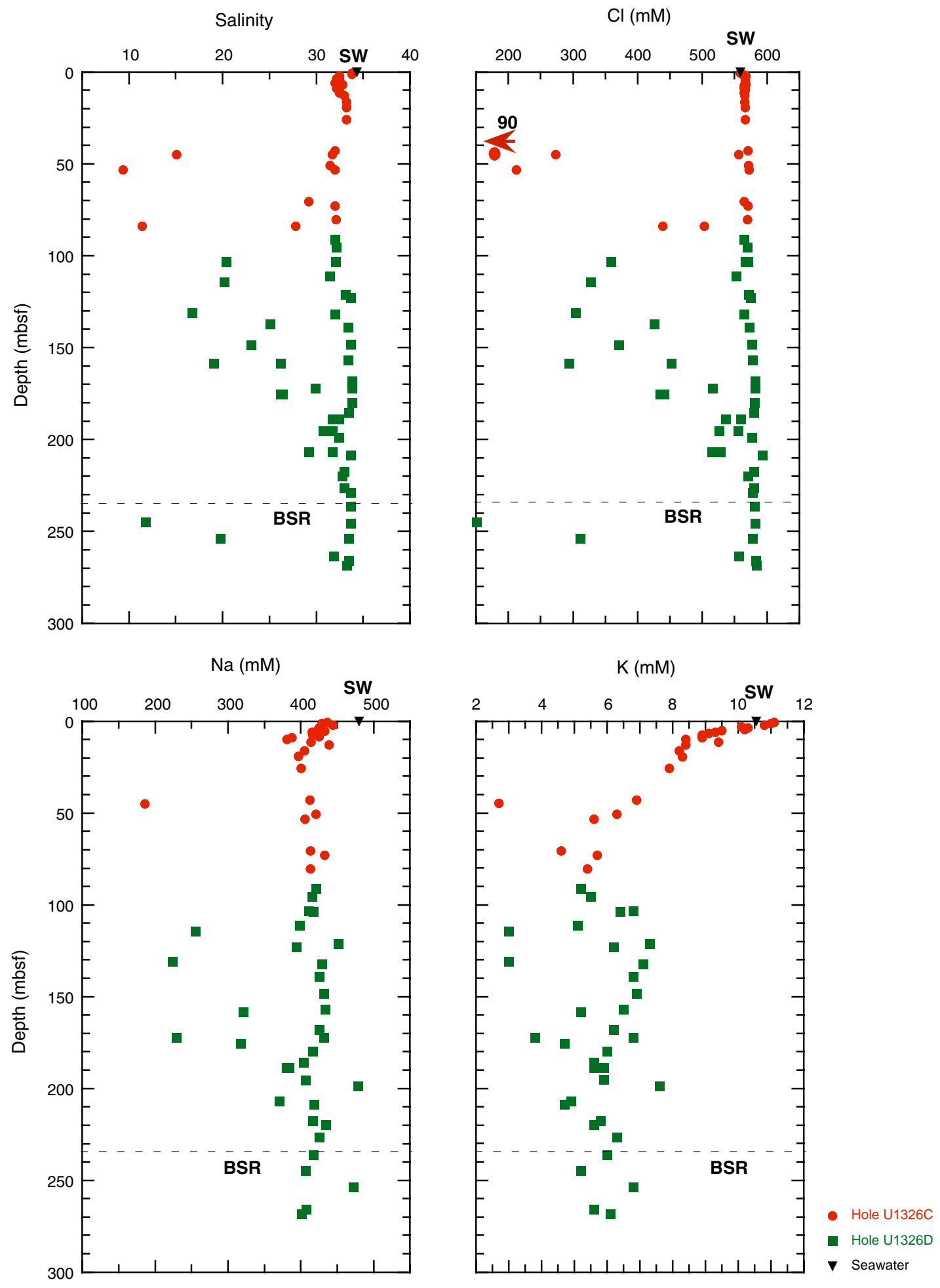
Figure F22. Concentration vs. depth profiles of alkalinity, sulfate, ammonium, and phosphate in interstitial waters from Holes U1326C (red circles) and U1326D (green squares). SW = seawater, BSR = seismically inferred bottom-simulating reflector.
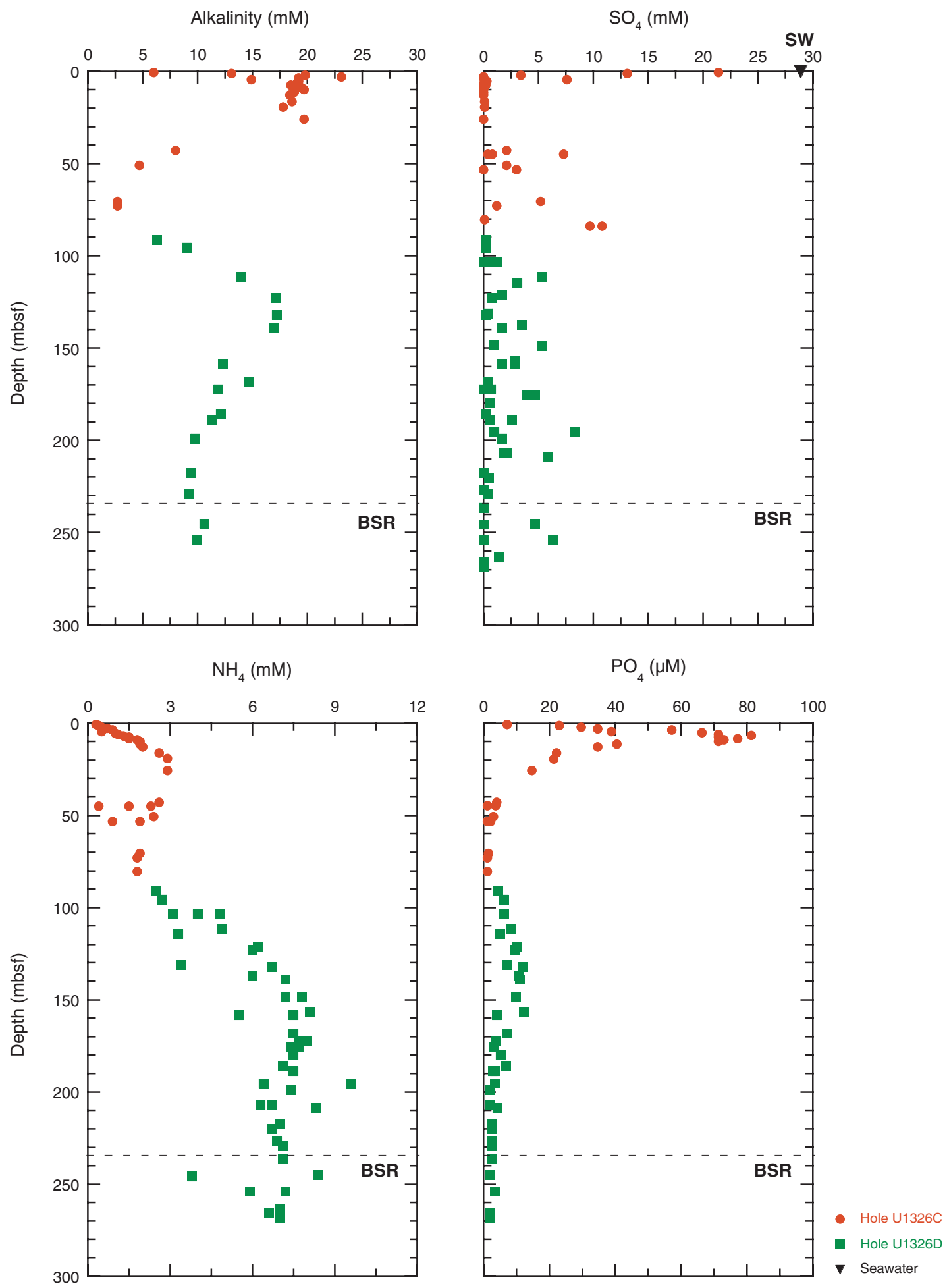
Figure F23. Concentration vs. depth profiles of calcium, magnesium, $\mathrm{Mg} / \mathrm{Ca}$ ratios, and strontium in interstitial waters from Holes U1326C (red circles) and U1326D (green squares). SW = seawater, BSR = seismically inferred bottom-simulating reflector.
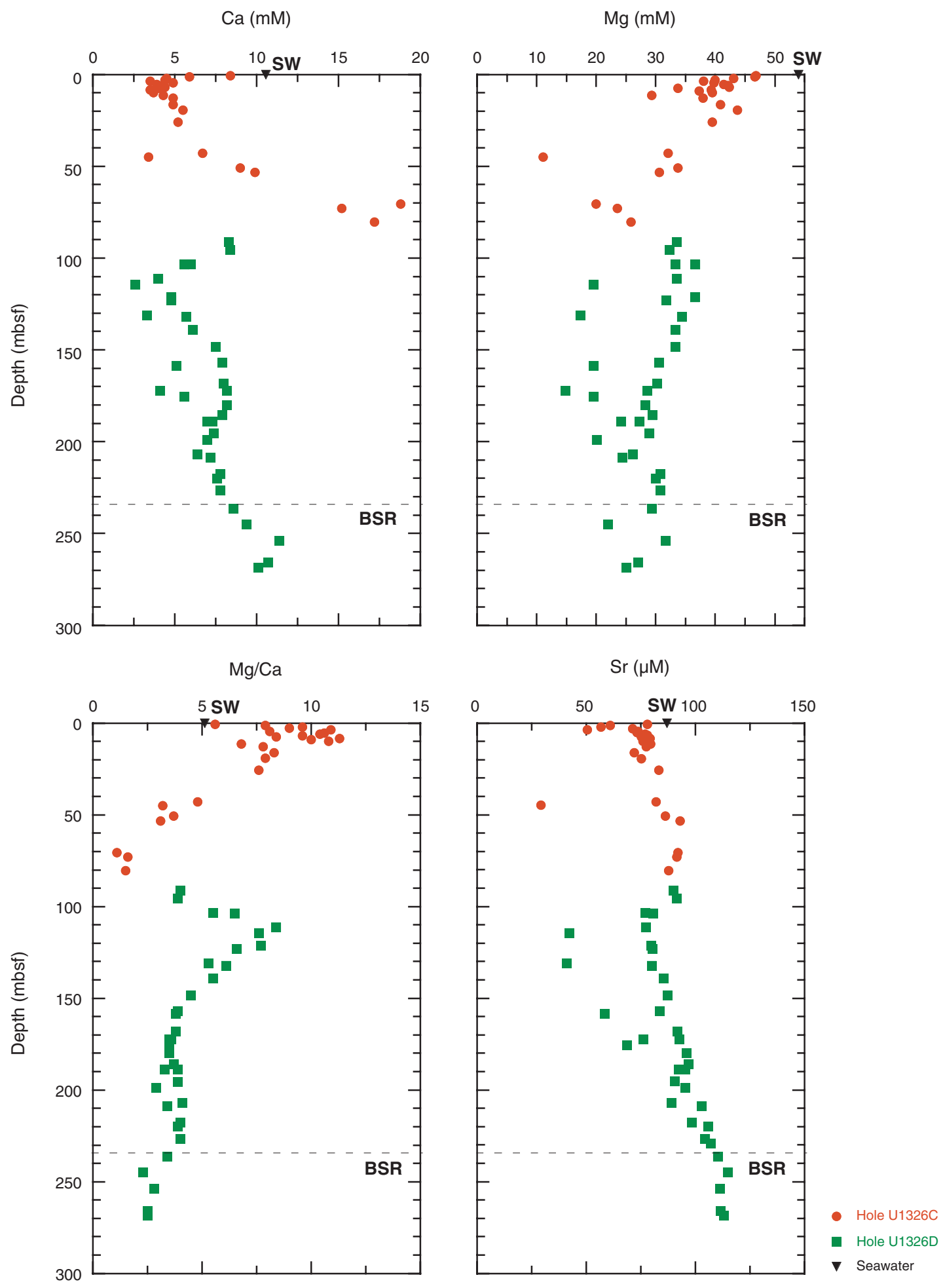
Figure F24. Concentration vs. depth profiles of lithium, boron, silica, and barium in interstitial waters from Holes U1326C (red circles) and U1326D (green squares). SW = seawater, BSR = seismically inferred bottomsimulating reflector.
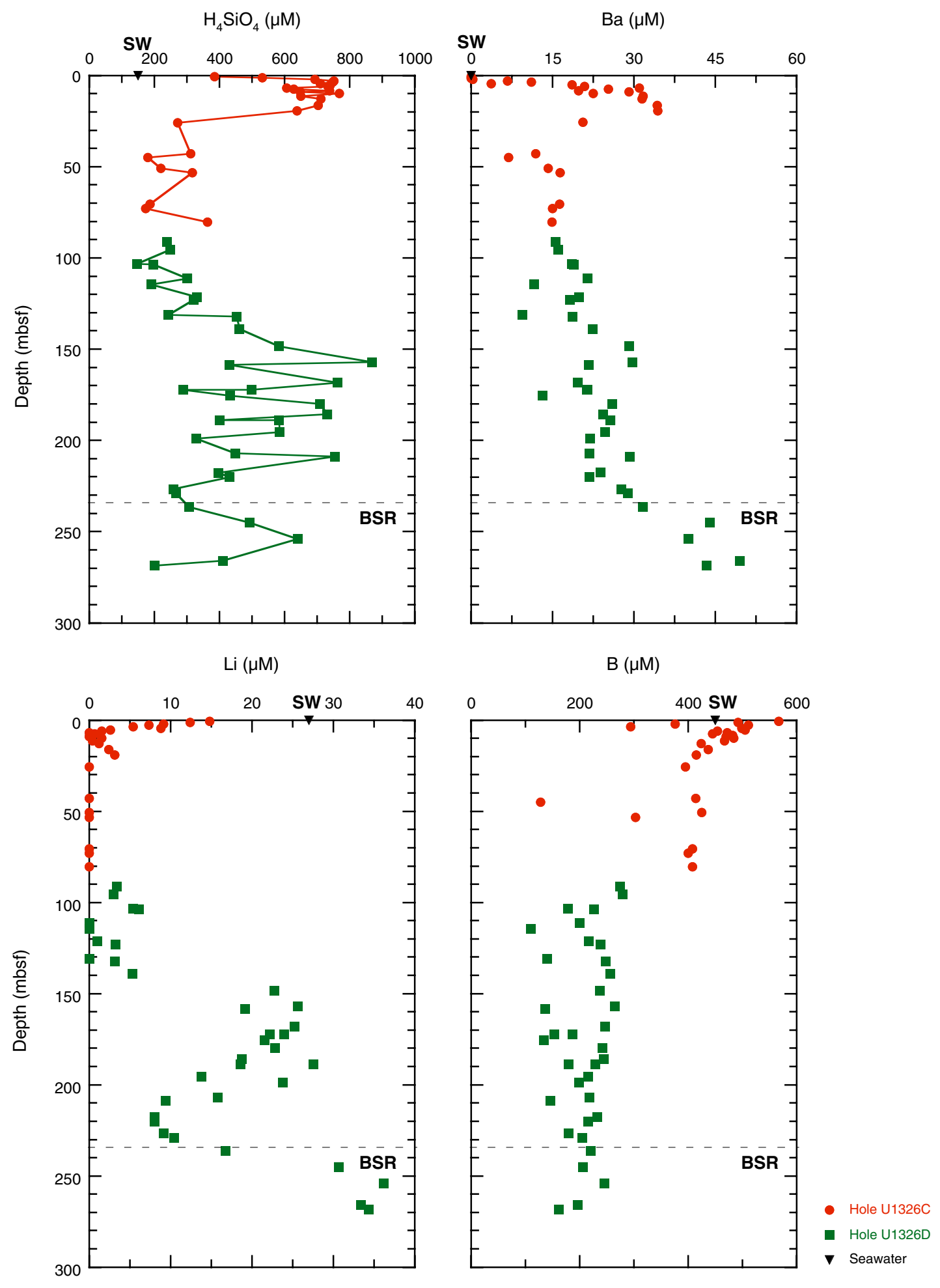
Figure F25. Concentrations of methane and ethane in headspace gas samples from Site U1326. BSR = bottomsimulating reflector.

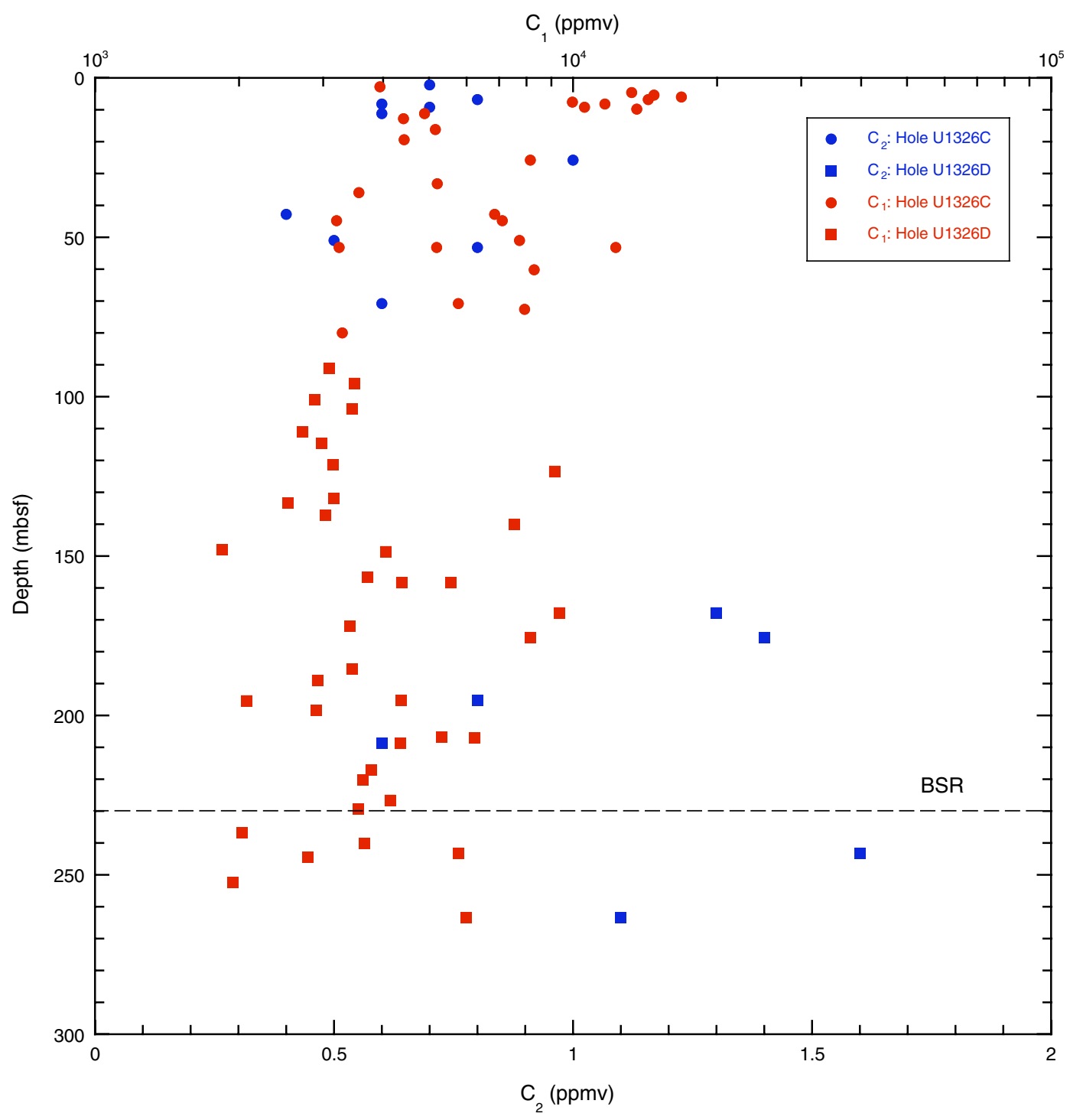


Figure F26. Concentrations of ethane, propane, $i$-butane, and $n$-butane in void gas samples from Site U1326. BSR = bottom-simulating reflector.

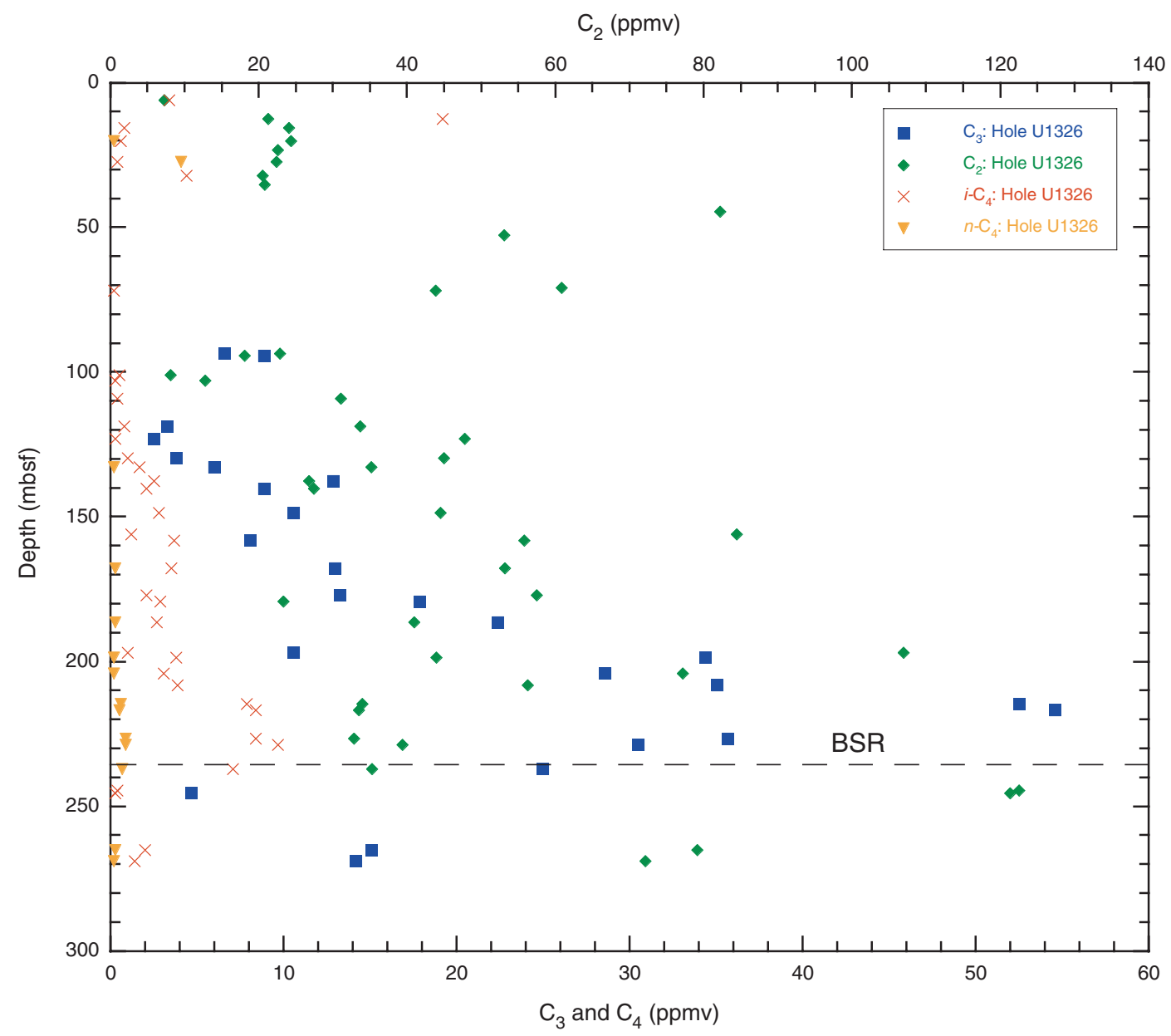


Figure F27. $\mathrm{C}_{1} / \mathrm{C}_{2}$ and $i-\mathrm{C}_{4} / n-\mathrm{C}_{4}$ ratios in void gas, gas hydrate (HYD), and PCS gas samples from Site U1326. $\mathrm{BSR}=$ bottom-simulating reflector, $\mathrm{HYD}=$ gas hydrate, $\mathrm{PCS}=$ Pressure Core Sampler.

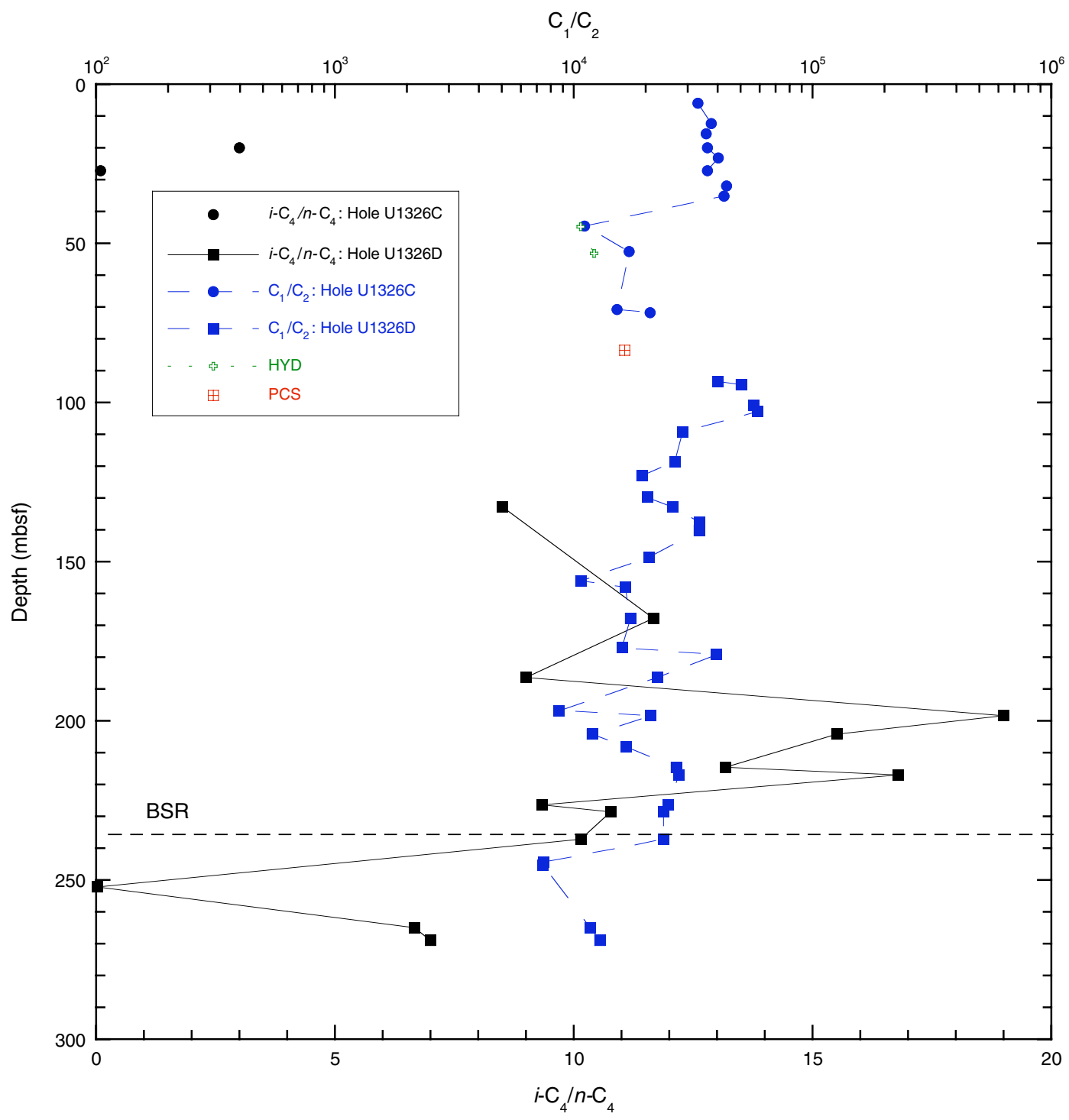


Figure F28. $\mathrm{C}_{1} / \mathrm{C}_{2}$ ratios vs. temperature at Site U1326. VAC = void gas, HS = headspace gas.

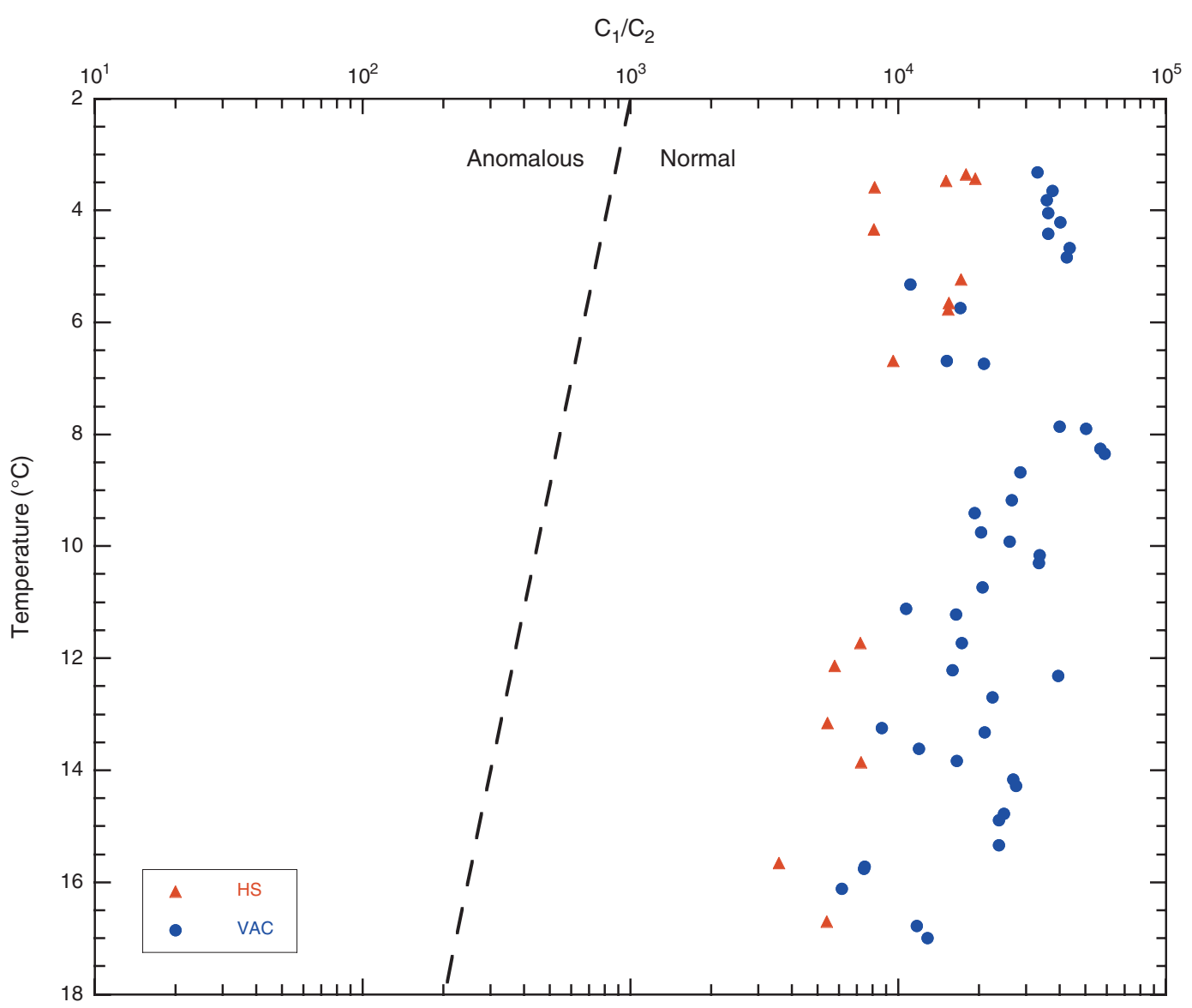


Figure F29. Dissolved sulfate and methane concentrations from Site U1326.

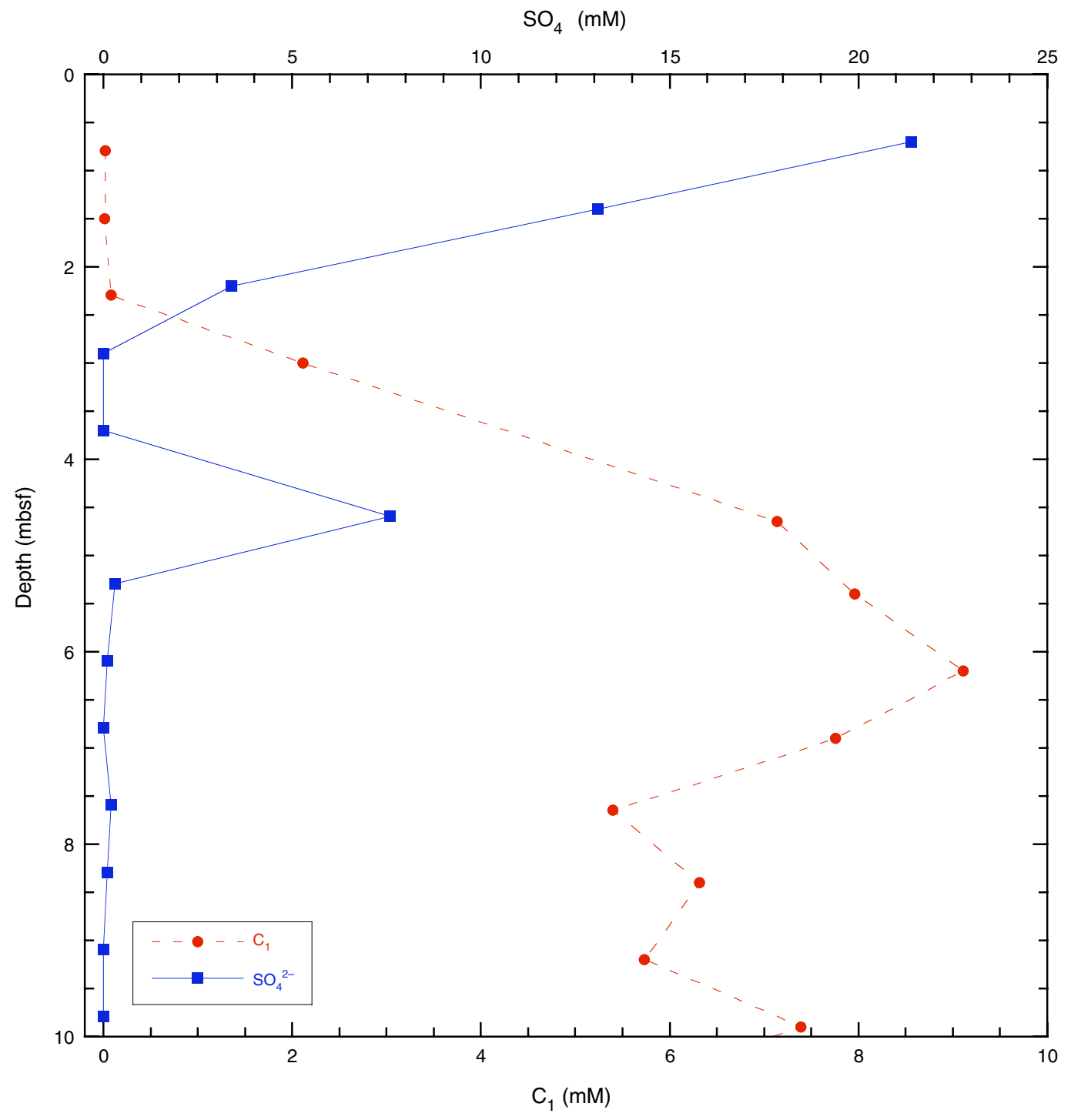


Figure F30. Concentrations of inorganic carbon (IC), calcium carbonate $\left(\mathrm{CaCO}_{3}\right)$, total organic carbon (TOC), total nitrogen (TN), and $\mathrm{C} / \mathrm{N}$ ratios in sediments from Site U1326. Data are plotted on different depth scales to highlight the overall site (0-200 mbsf) and near-surface (0-13 mbsf) trends. Dashed lines = lithostratigraphic unit boundaries.
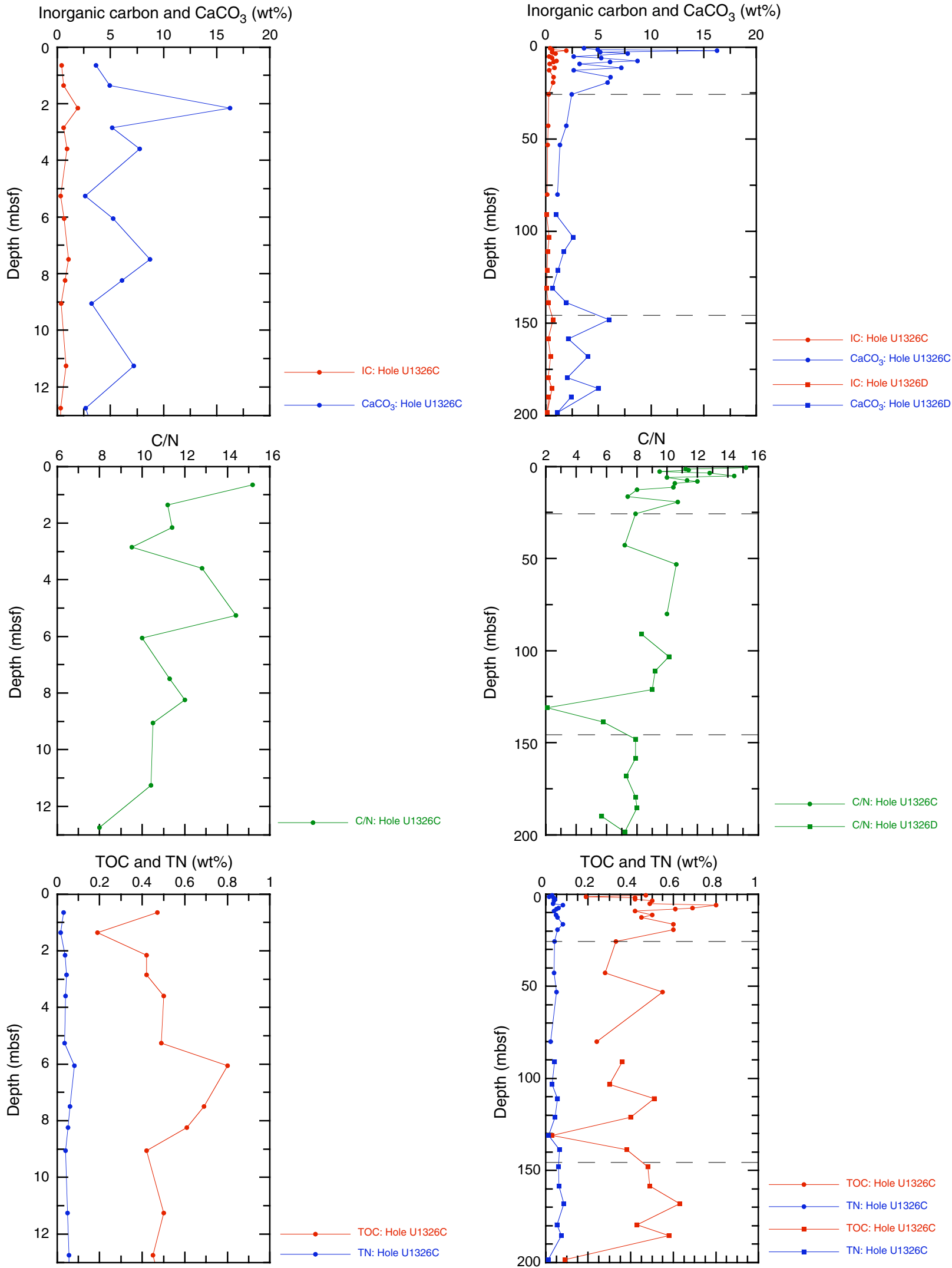
Figure F31. Overview of physical property data from Site U1326. Plotted from left to right are core recovery; logging-while-drilling (LWD) and moisture and density (MAD) porosity; LWD, multisensor track (MST), and MAD bulk density; MAD grain density; LWD, MST contact, and MST noncontact resistivity; MST magnetic susceptibility; thermal conductivity (line shows regional trend from Davis et al., 1990); Torvane and automated vane shear (AVS) strength; and lithostratigraphic units. BSR = bottom-simulating reflector.
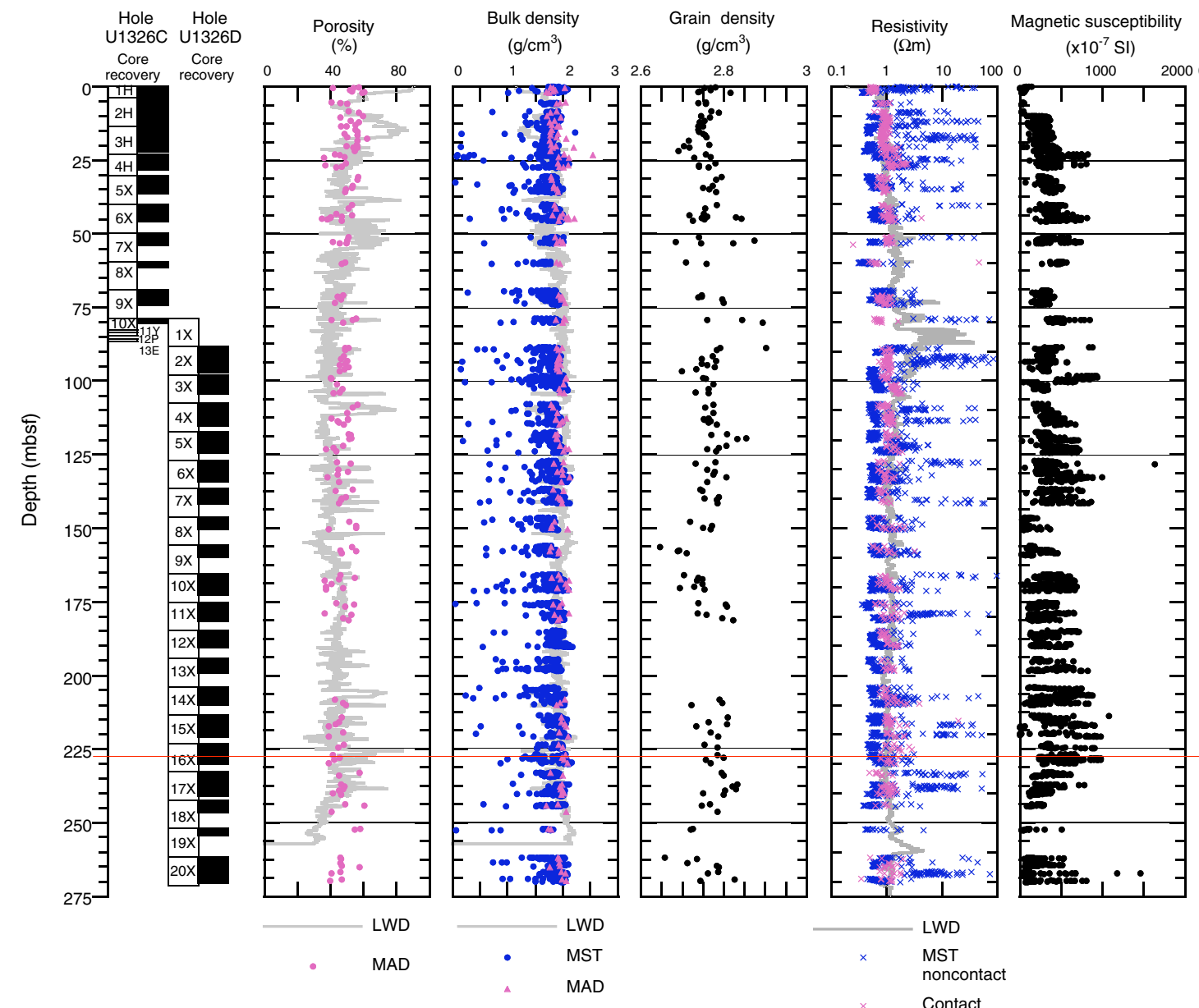

Thermal conductivity Shear strength

$100 \quad 200 \quad 300 \quad$ Lith. unit
0
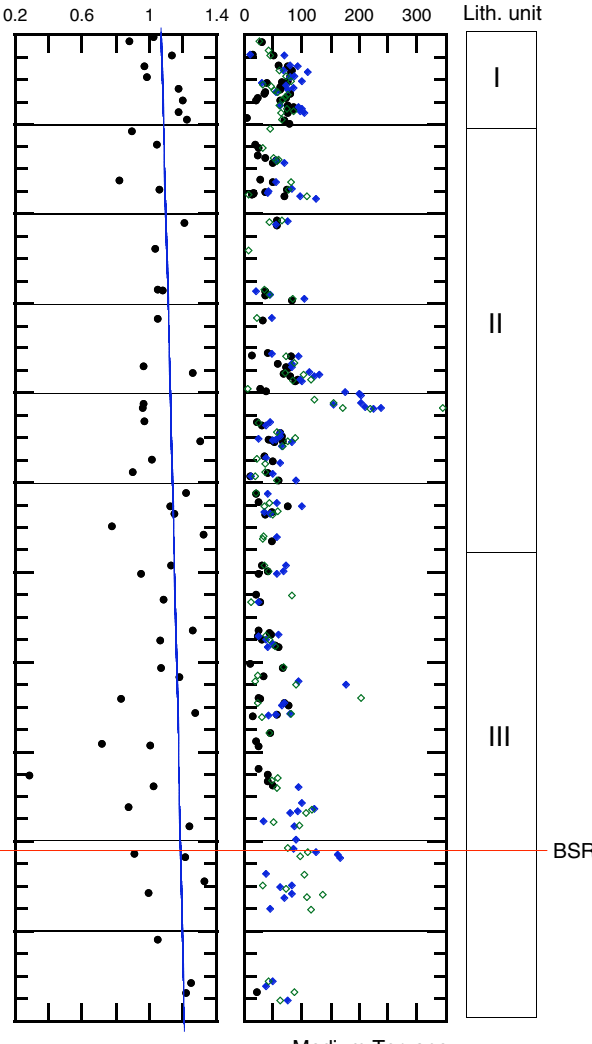

- Medium Torvane

- Small Torvane

AvS

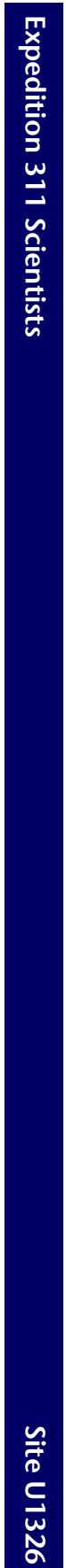


Figure F32. Combined infrared (IR) images of core liner temperature from Holes U1326C and U1326D compared to logging-while-drilling/measurement-while-drilling (LWD/MWD) resistivity and calculated pore water saturation from Hole U1326A. Core recovery and core handling time are also shown. BSR = bottom-simulating reflector. (This figure is also available in an oversized format.)

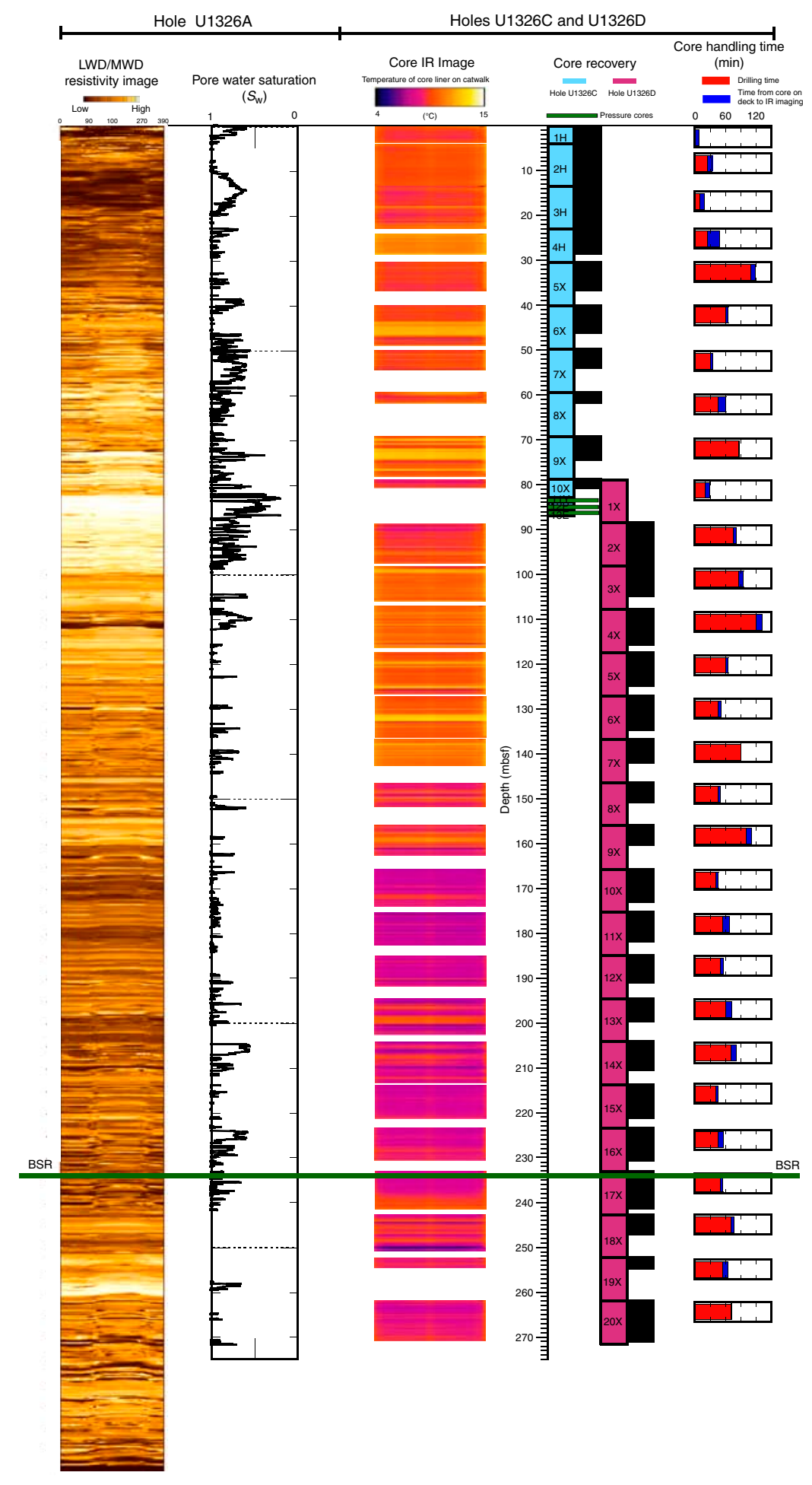


Figure F33. A. Downhole temperatures based on concatenation of core liner temperatures averaged across each pixel row (see text for details). B. Detail of the temperature profile for 240-255 mbsf. Note the numerous, strong cold temperature anomalies. C. Infrared (IR) image of Core 311-U1326D-18X. D. Section 311-U1326D$18 \mathrm{X}-4$ showing "foamy" sediment. The liner was split to expose the whole-round core. Note the shrinkage of the core. This sediment was unusually dry and full of tiny gas bubbles.

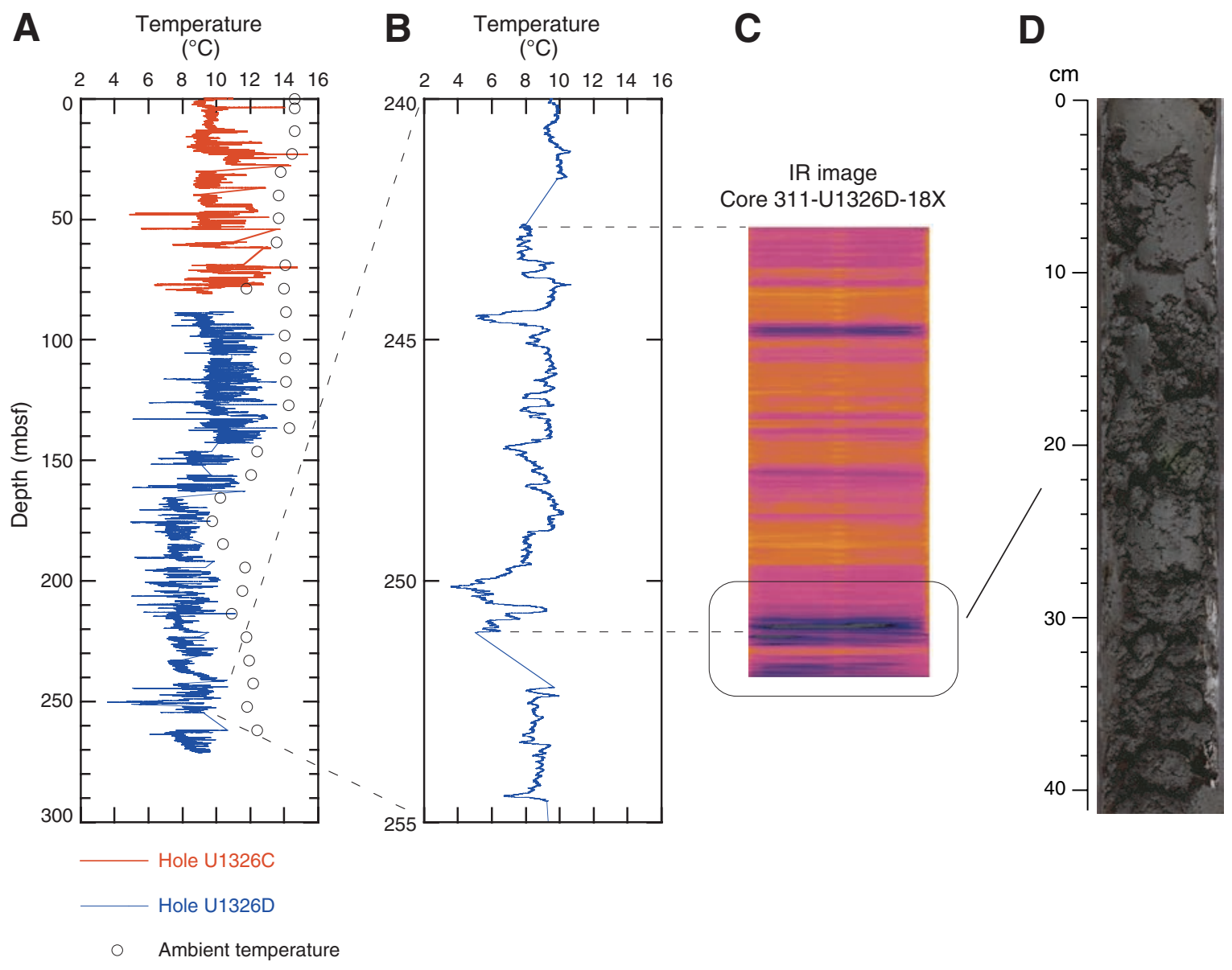


Figure F34. Catwalk temperature and light intensity recorded during Expedition 311. Measurements were made $2.35 \mathrm{~m}$ from the core 0 point (end of catwalk closest to rig floor). Diurnal temperature changes that were characteristic of the early days of the expedition, when days were bright and sunny, were muted during the latter part of the expedition. Note the large, abrupt change in temperature that occurred during coring at Site U1326. Times (open symbols) of collecting individual cores are shown at the top of the figure for all sites. Each symbol corresponds to a single core. GMT = Greenwich Mean Time.

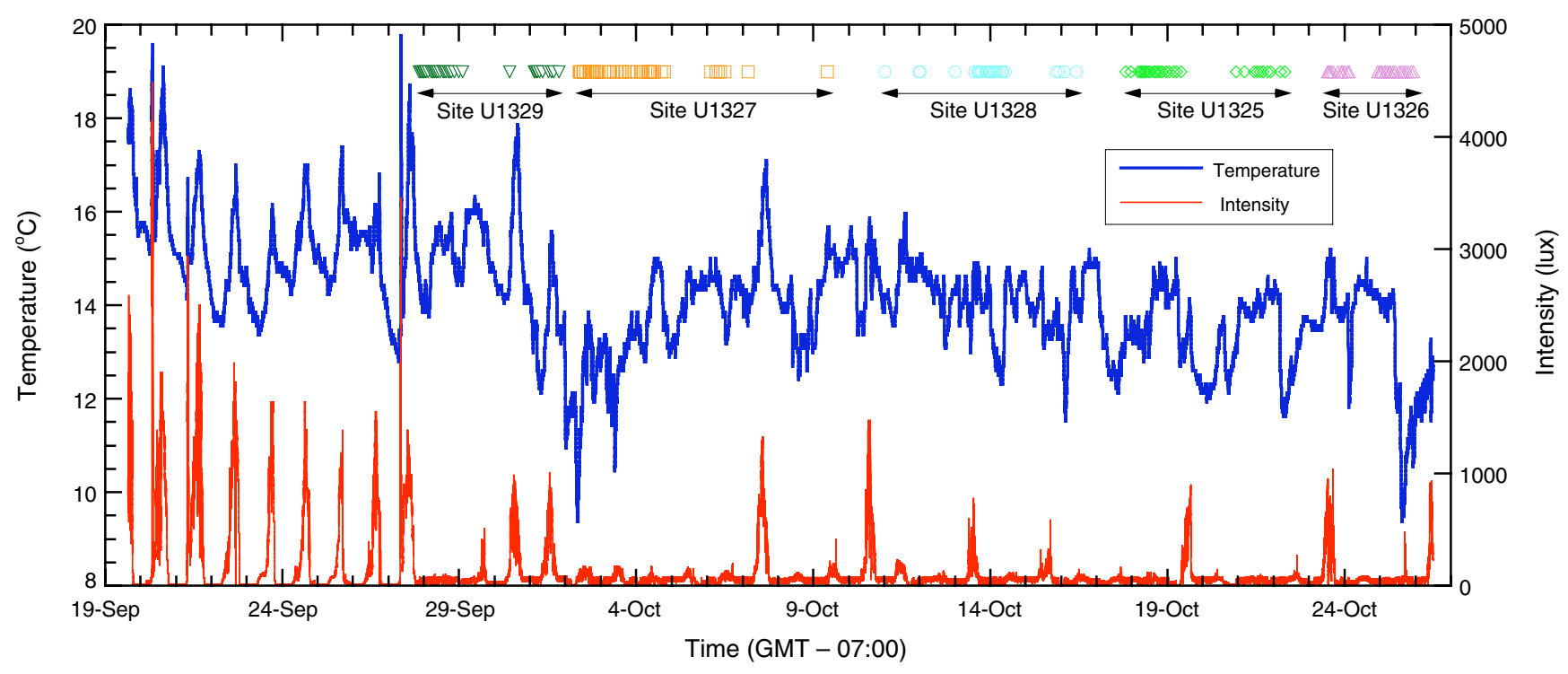


Figure F35. A. Sample of a sand layer containing gas hydrate in Sample 311-U1326C-6X-4, 83-96 cm. B. IR image of the same sample. C. Temperature profile along the IR image green line shown in B.

A

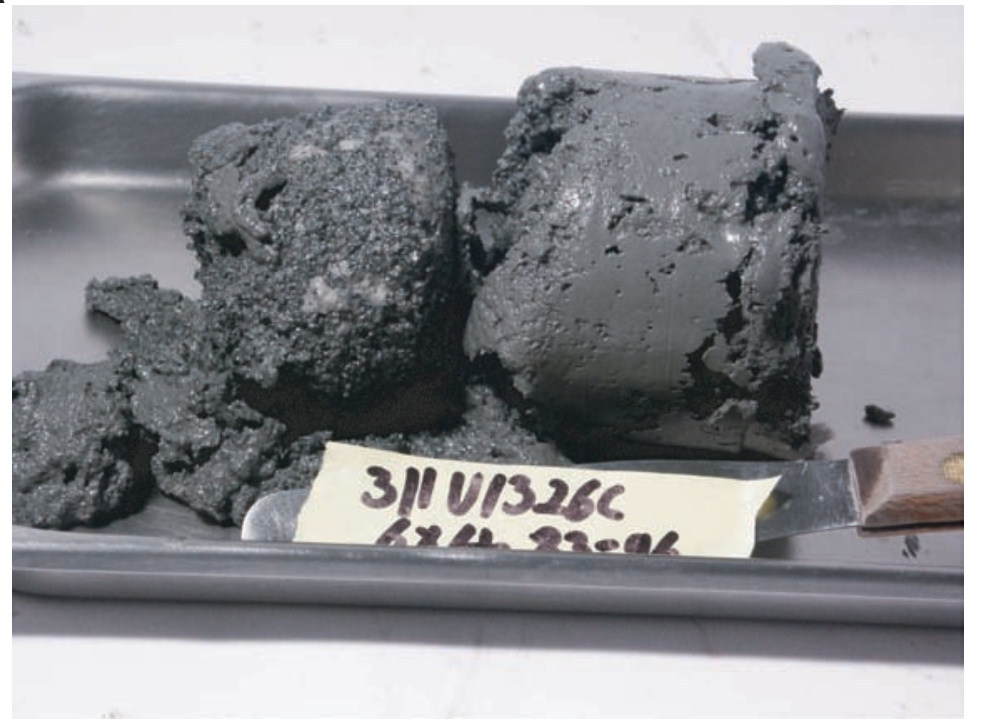

B

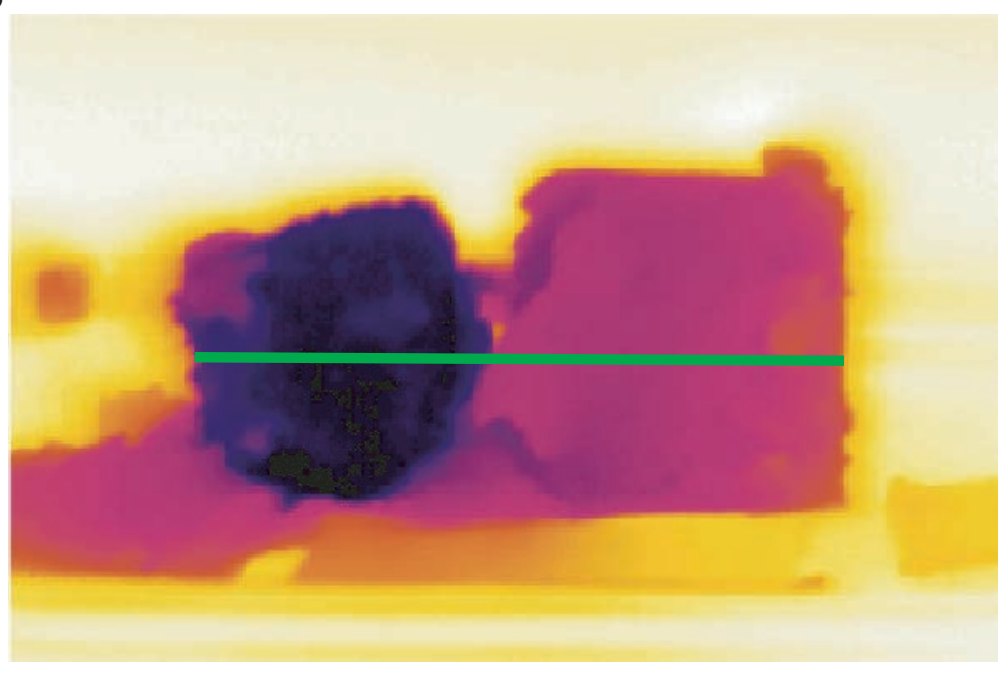

C
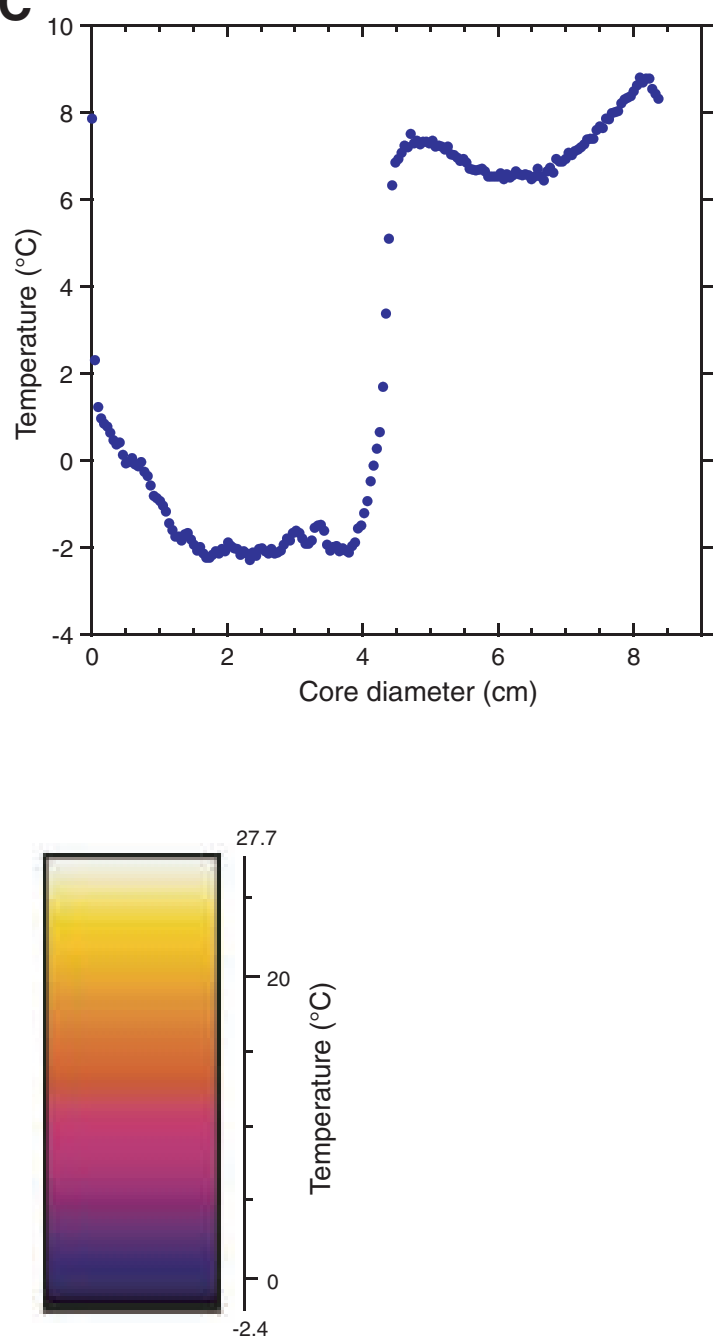
Figure F36. $P$-wave velocity measurements made using the multisensor track (MST) and Hamilton frame at Site U1326 compared to velocities from Site U1325. PWS = P-wave sensor.

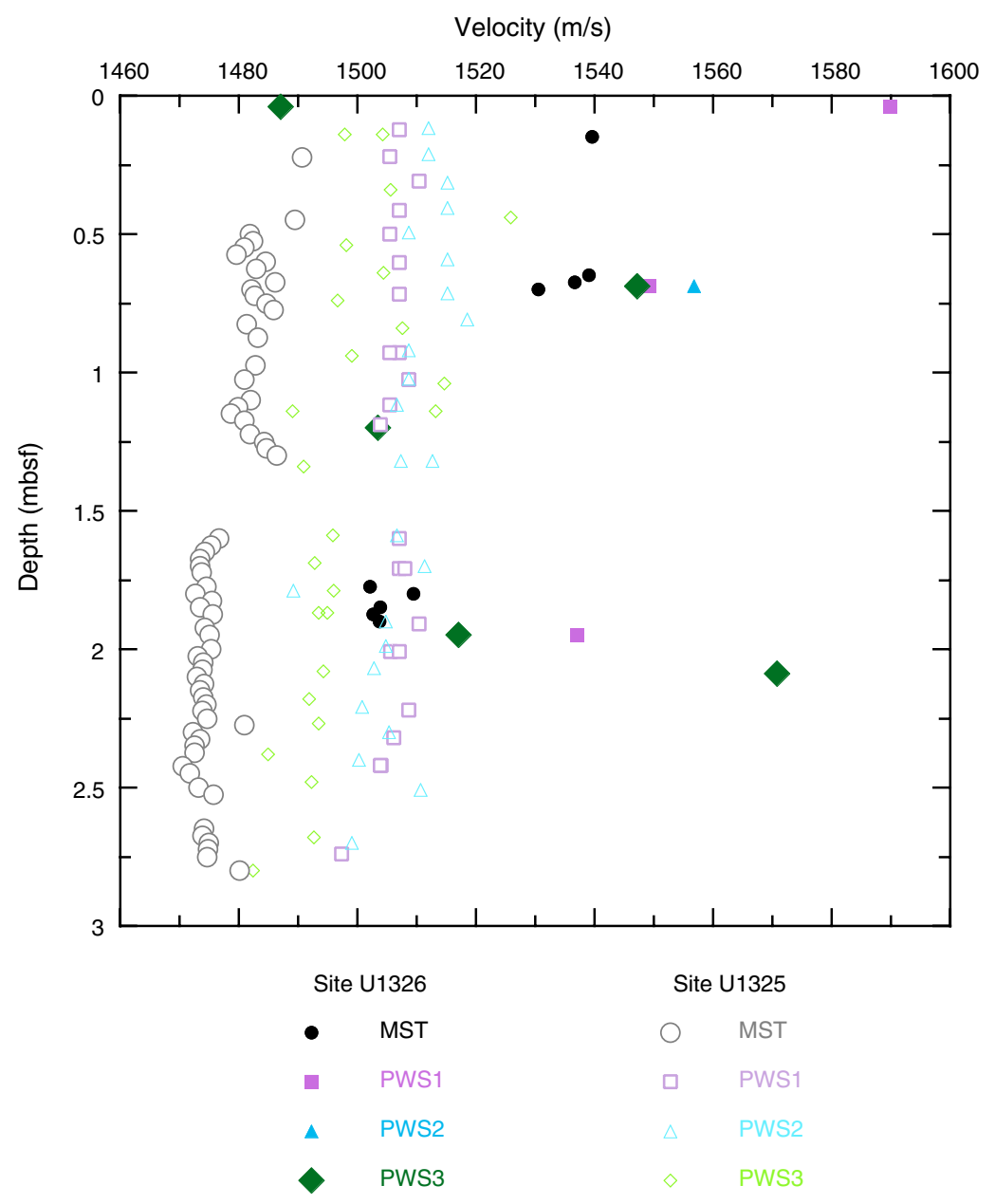


Figure F37. A. Comparison between automated vane shear (AVS) and handheld Torvane shear strength measurements from Site U1326. B. Overburden pressure calculated from MAD bulk density data. C. Ratio of shear strength to overburden pressure. This provides information on the degree of sediment underconsolidation or overconsolidation.

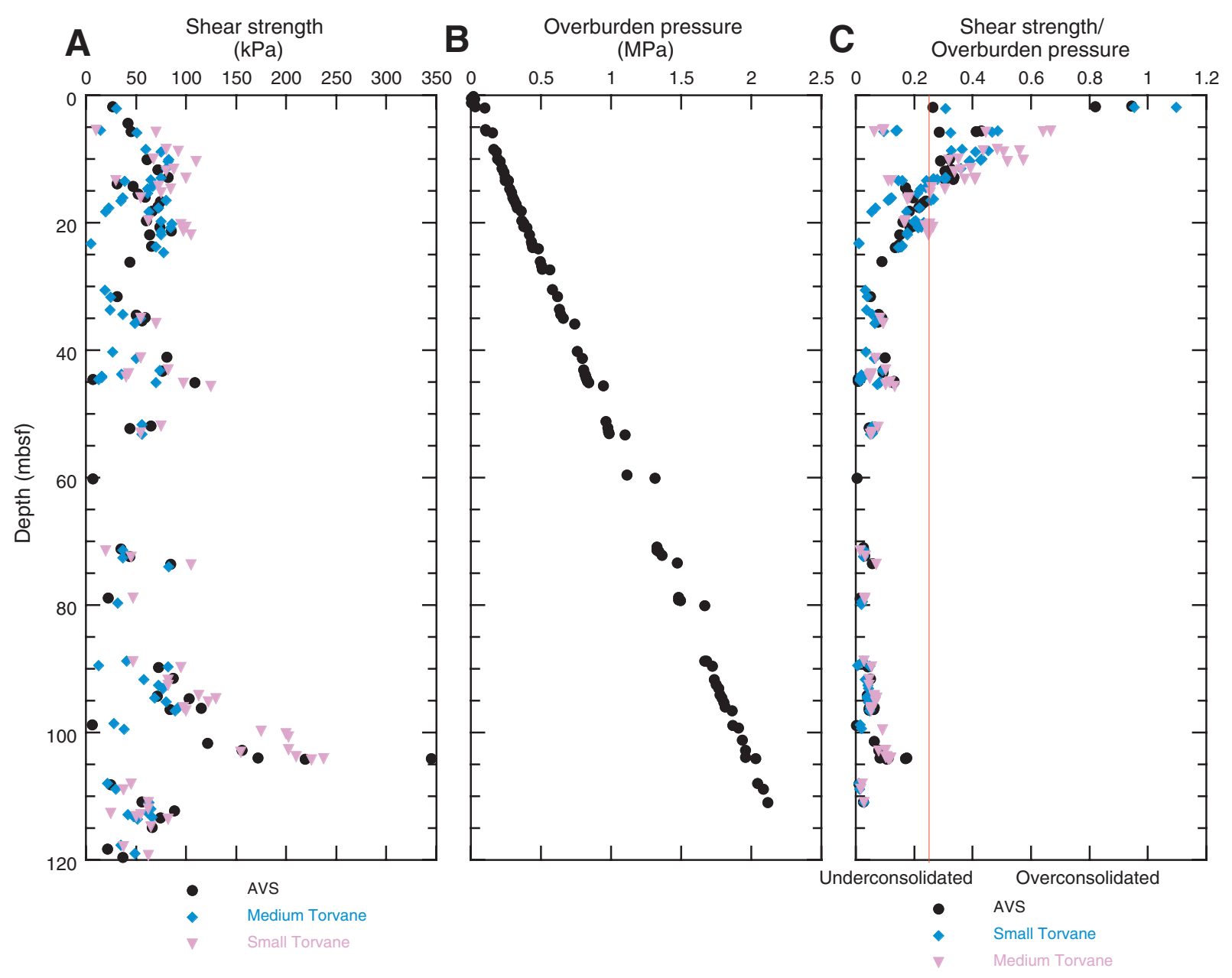


Figure F38. A. Comparison of pore water resistivity calculated from interstitial water salinity using equations developed by Fofonoff (1985) and bulk volume contact resistivity of sediments from Site U1326. Both sets of values have been corrected to $20^{\circ} \mathrm{C}$. B. Formation factor (ratio of pore water resistivity to sediment resistivity). C. Comparison of porosity derived from moisture and density (MAD) measurements and Archie's equation. (Continued on next page).
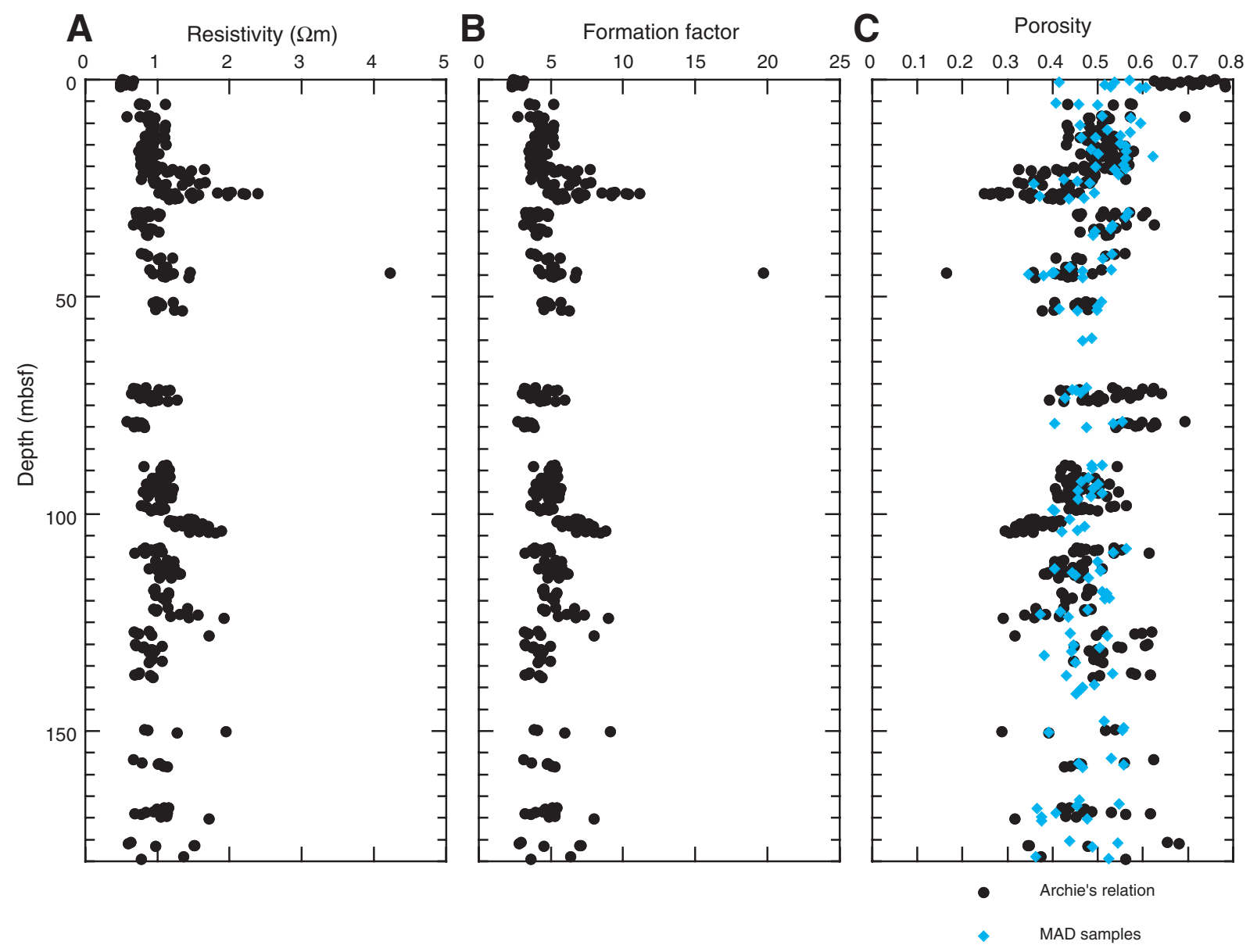
Figure F38 (continued). D. Formation factor vs. MAD porosity. Best-fit Archie's parameters were determined separately for porosities $>0.45$ (dark gray) and $<0.45$ (light blue).

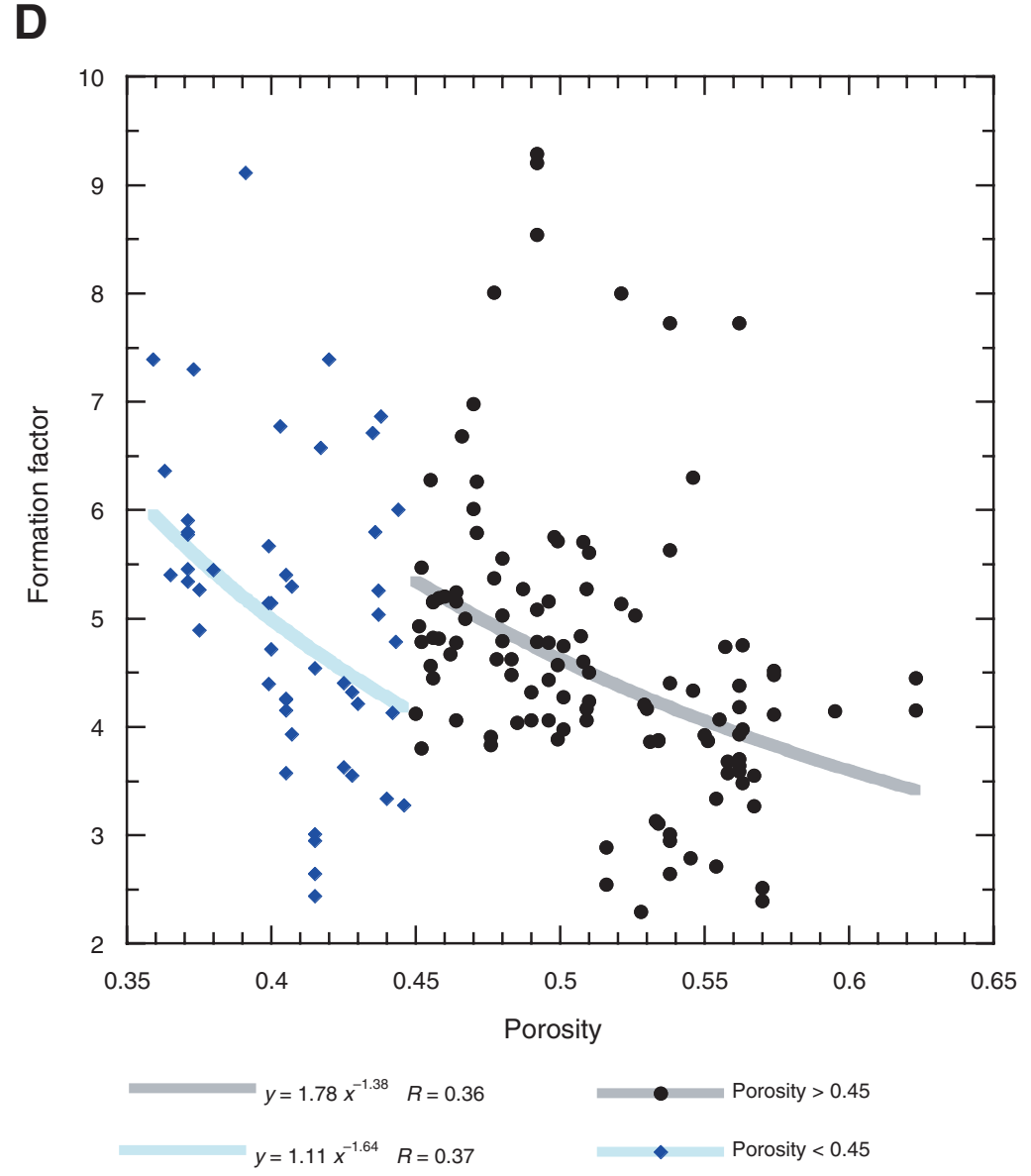


Figure F39. Third-generation advanced piston corer temperature (APCT-3; APC3 in figure) tool and Davis-Villinger Temperature Probe (DVTP) in situ temperature data from Site U1326. Both the upper (black) and lower (blue) thermistors are shown for DVTP data.
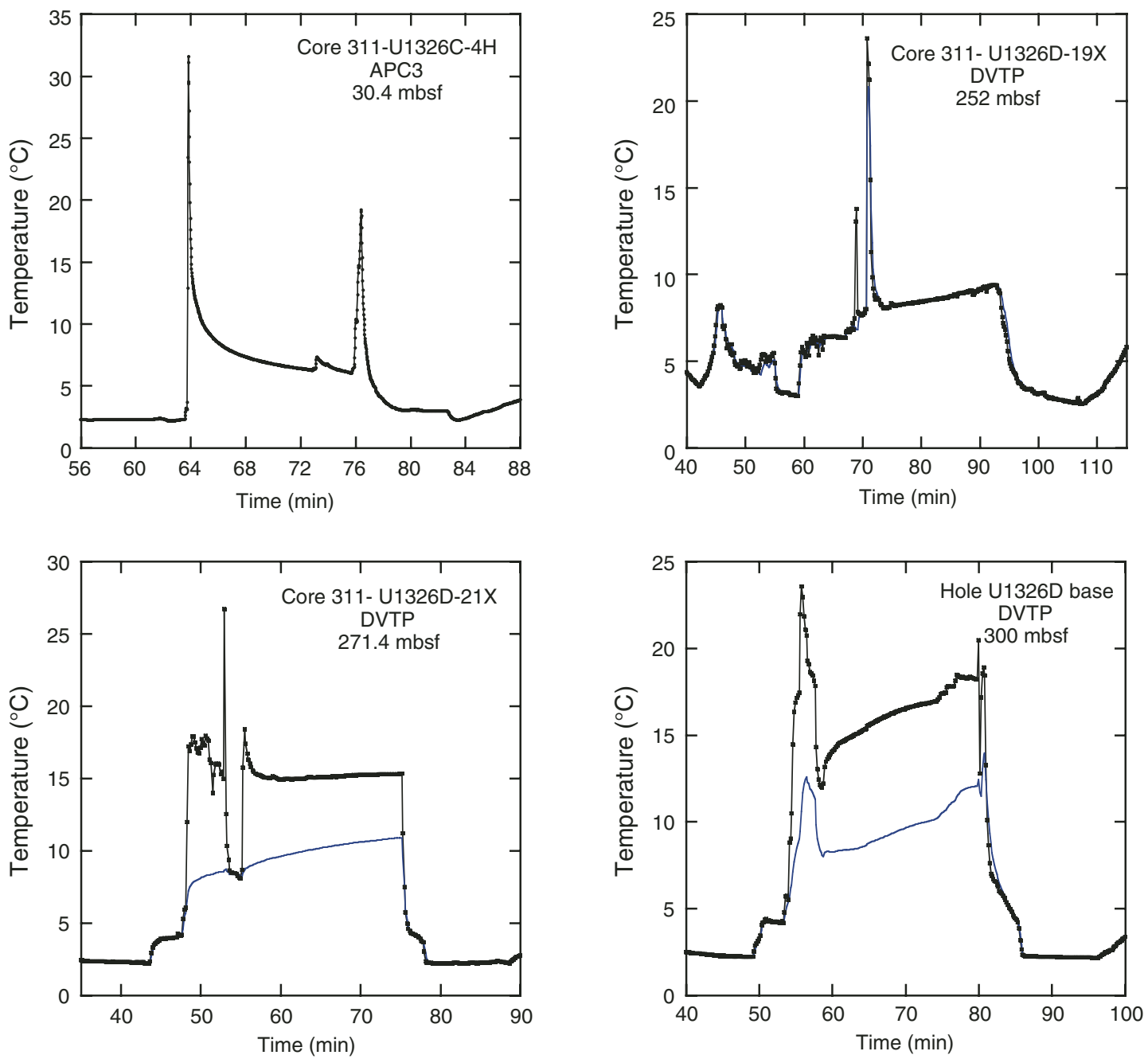
Figure F40. A. All reliable in situ temperature measurements obtained during Expedition 311. Data from ODP Leg 146 Site 889 are also included. B. Regional heat flow trend (dashed lines; Hyndman and Wang, 1993) compared to heat flow estimated at Sites U1325-U1329 assuming a thermal conductivity value of $1.1 \mathrm{~W} /$ $(\mathrm{m} \cdot \mathrm{K})$. The depth to the base of the gas hydrate stability zone (GHSZ) implied by the temperature measurements is also shown. C. Seismic transect across the margin showing the structural setting of the Expedition 311 sites. BSR = bottom-simulating reflector.
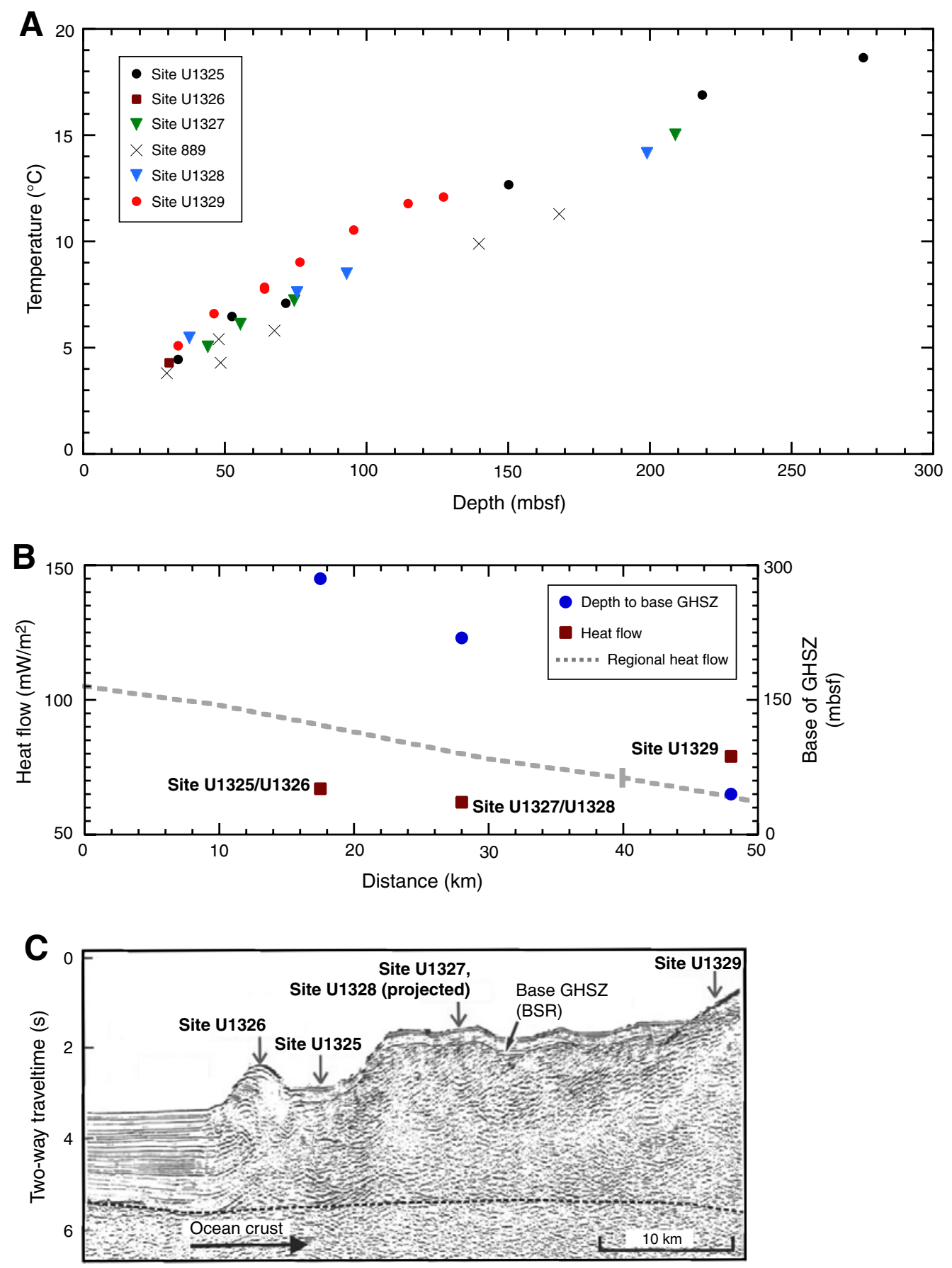
Figure F41. Paleomagnetic data after $20 \mathrm{mT}$ alternating-field demagnetization from Holes U1326C and U1326D.

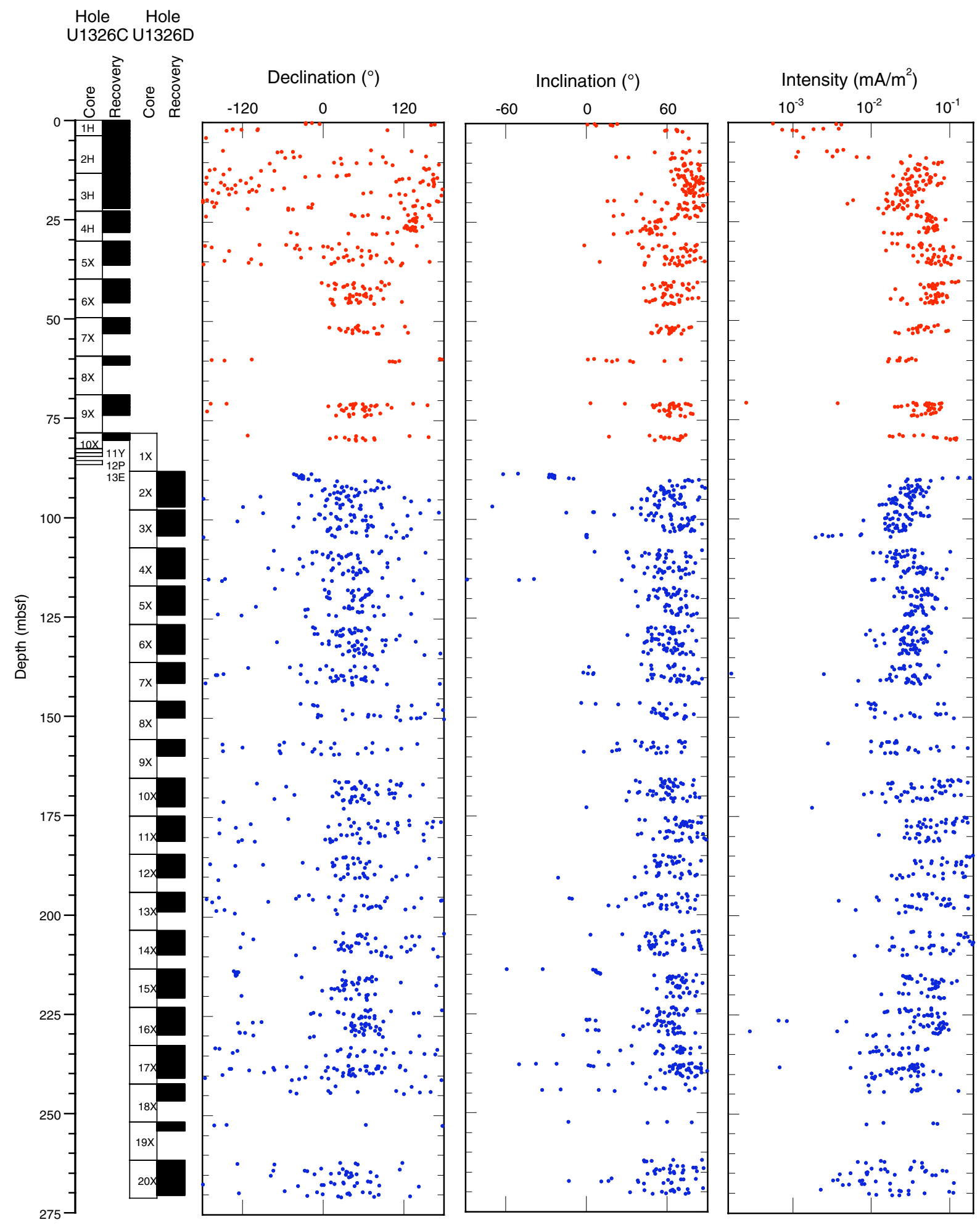


Figure F42. Temperature and pressure vs. elapsed time for each pressure core deployment as recorded by the corer's internal data logger. Deployment and recovery are shaded orange, operation at coring depth is shaded yellow, and autoclave immersion in the cold shuck is shaded blue. There are no data for Core 311-U1326C$13 \mathrm{E}$.
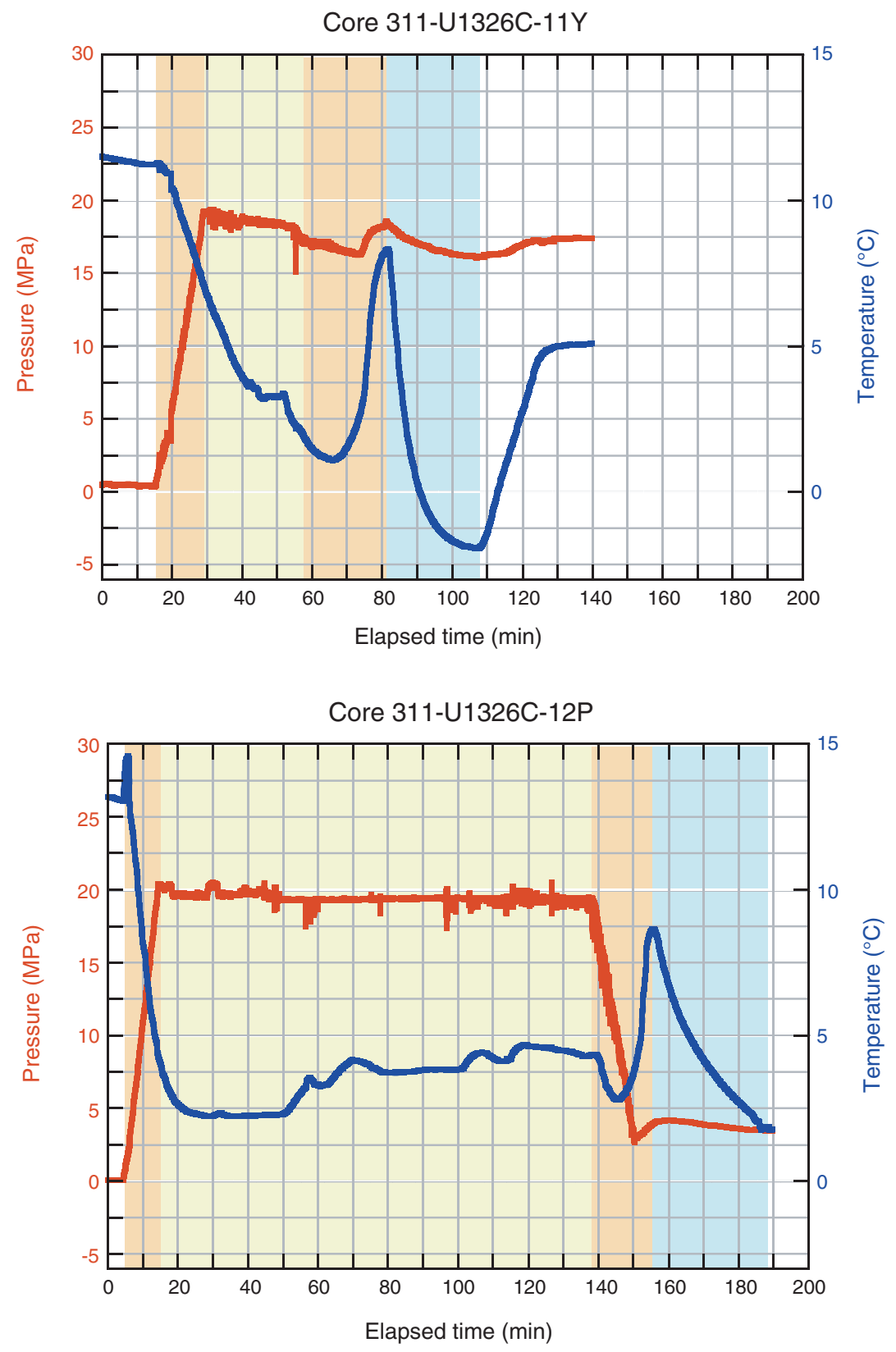
Figure F43. Temperature vs. pressure for all pressure core deployments, showing trajectories relative to gas hydrate stability at 30 and 40 ppt salinity $(\mathrm{Xu}, 2002,2004)$. Circles = final temperature and pressure of autoclave prior to data logger removal, squares = pressure and temperature conditions in the cold laboratory van. There are no data for the deployment of Core 311-U1326C-13E.

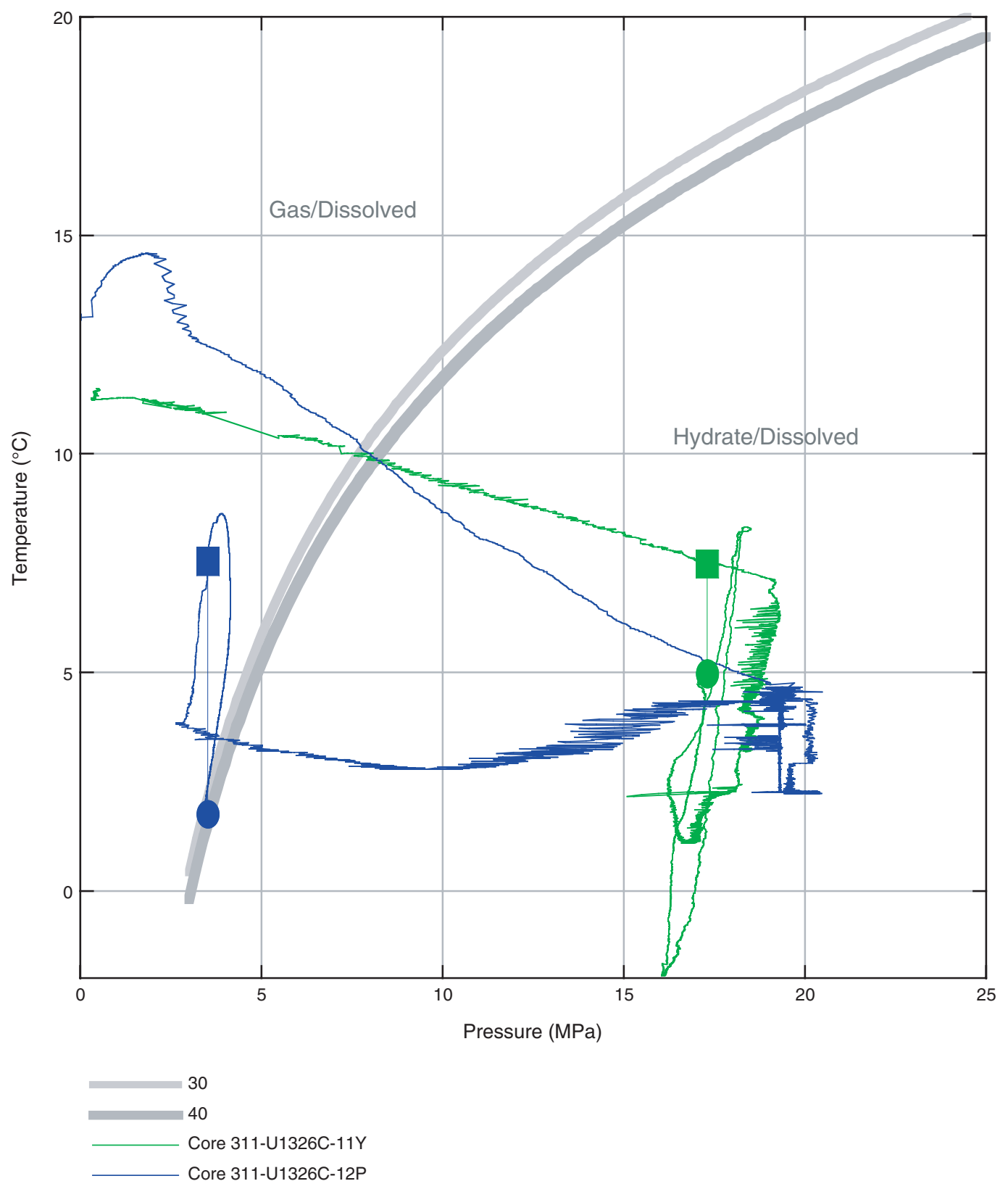


Figure F44. Methane phase diagram with total methane concentration measured from the single degassed PCS core at Site U1326. The seafloor temperature was estimated from previous sites, the salinity profile was taken from Table T4, and methane saturation was calculated according to Xu $(2002,2004)$. Methane phase boundaries for five different thermal gradients are plotted, as in situ temperature measurements were extremely difficult at this site (see "In situ temperature profile"). BSR = bottom-simulating reflector.

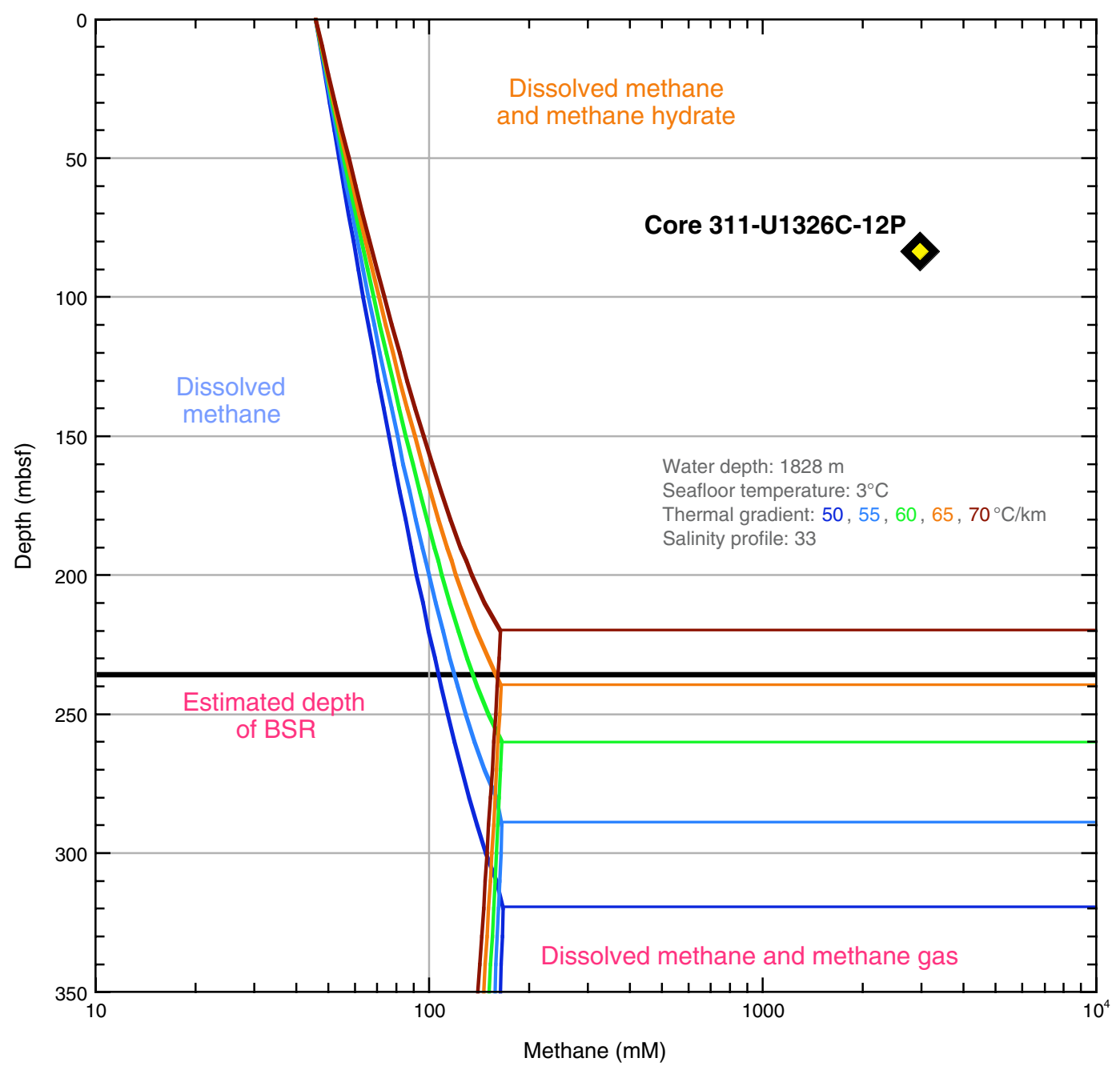


Figure F45. Pressure vs. released gas volume for PCS Core 311-U1326C-12P. Arrows = placement of gamma ray density scans.

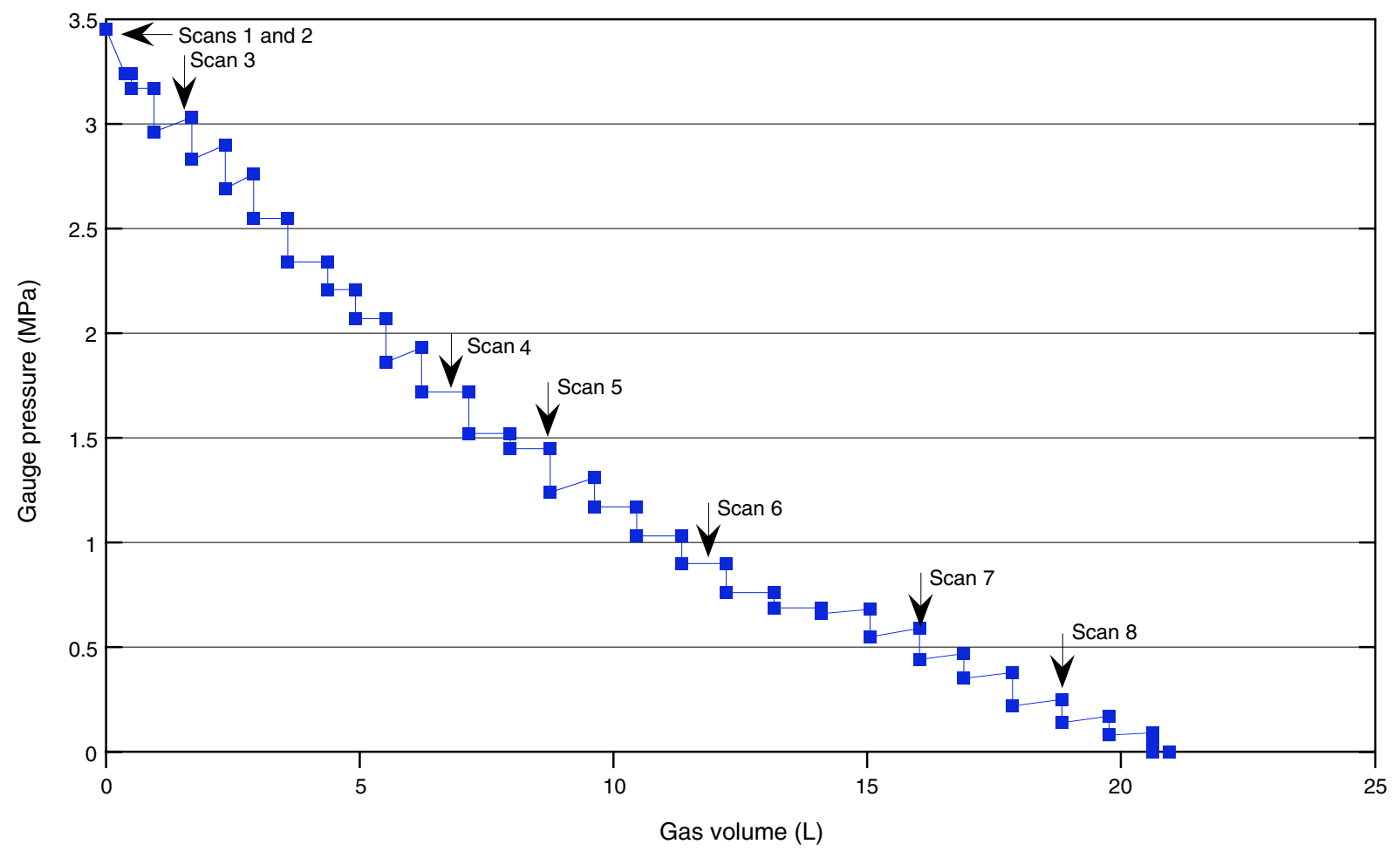


Figure F46. Summary of data collected from Core 311-U1326C-12P, including gamma ray density scans collected during degassing, X-ray images collected before degassing, and chlorinity data collected in selected zones after core extrusion. Gamma ray density scans were shown as differential density plots (i.e., as profiles from which the initial profile has been subtracted). The colored boxes indicate the initial state of the core before degassing (brown $=$ sediment, blue $=$ water, light green $=$ gas) .
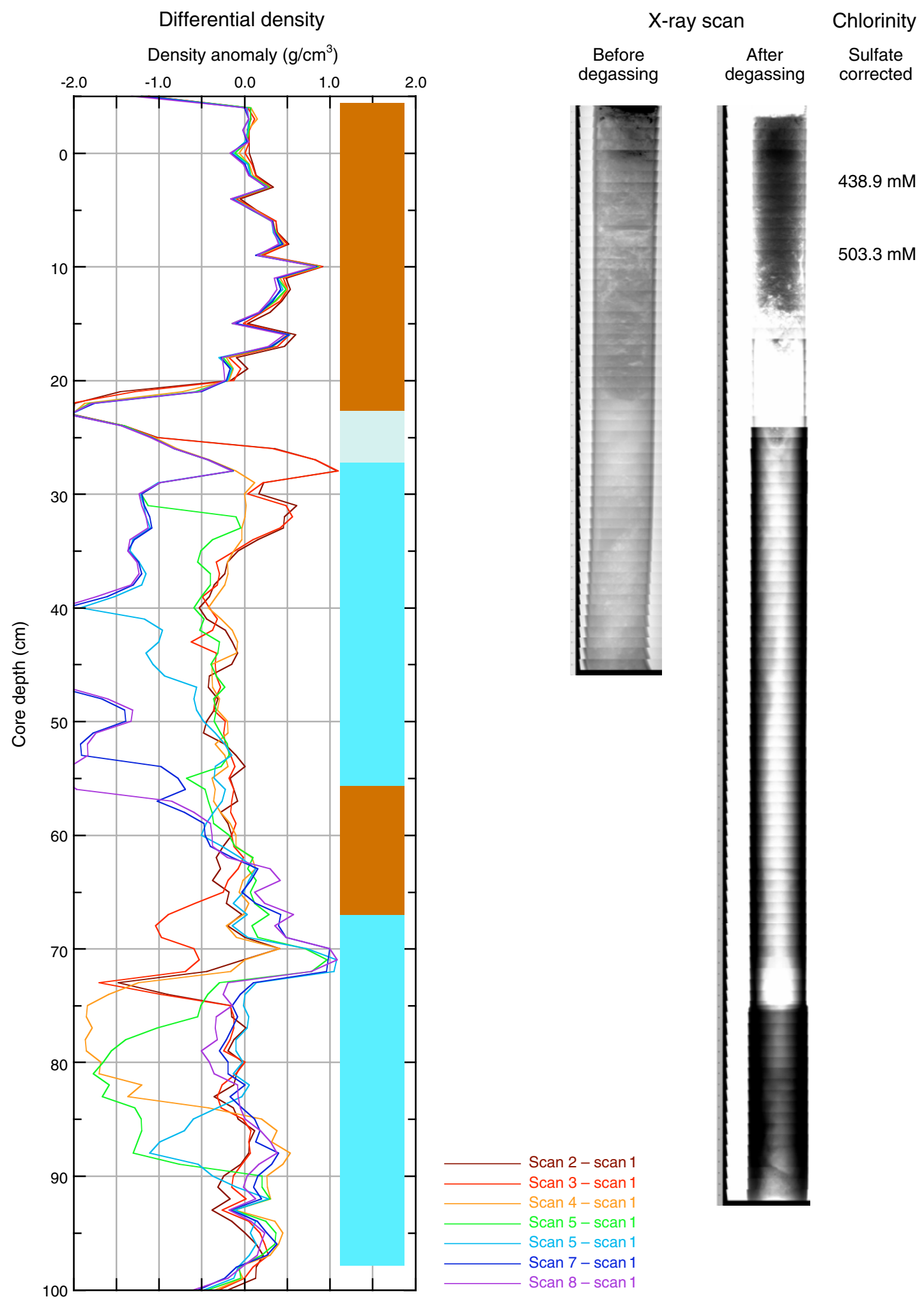

$438.9 \mathrm{mM}$

$503.3 \mathrm{mM}$ 
Figure F47. Pressure core data collected at $18 \mathrm{MPa}$ and $7^{\circ} \mathrm{C}$ for Core 311-U1326C-11Y, including gamma ray density, $P$-wave velocity, and X-ray image. The X-ray image has been stretched $250 \%$ in the cross-core direction to show detail.
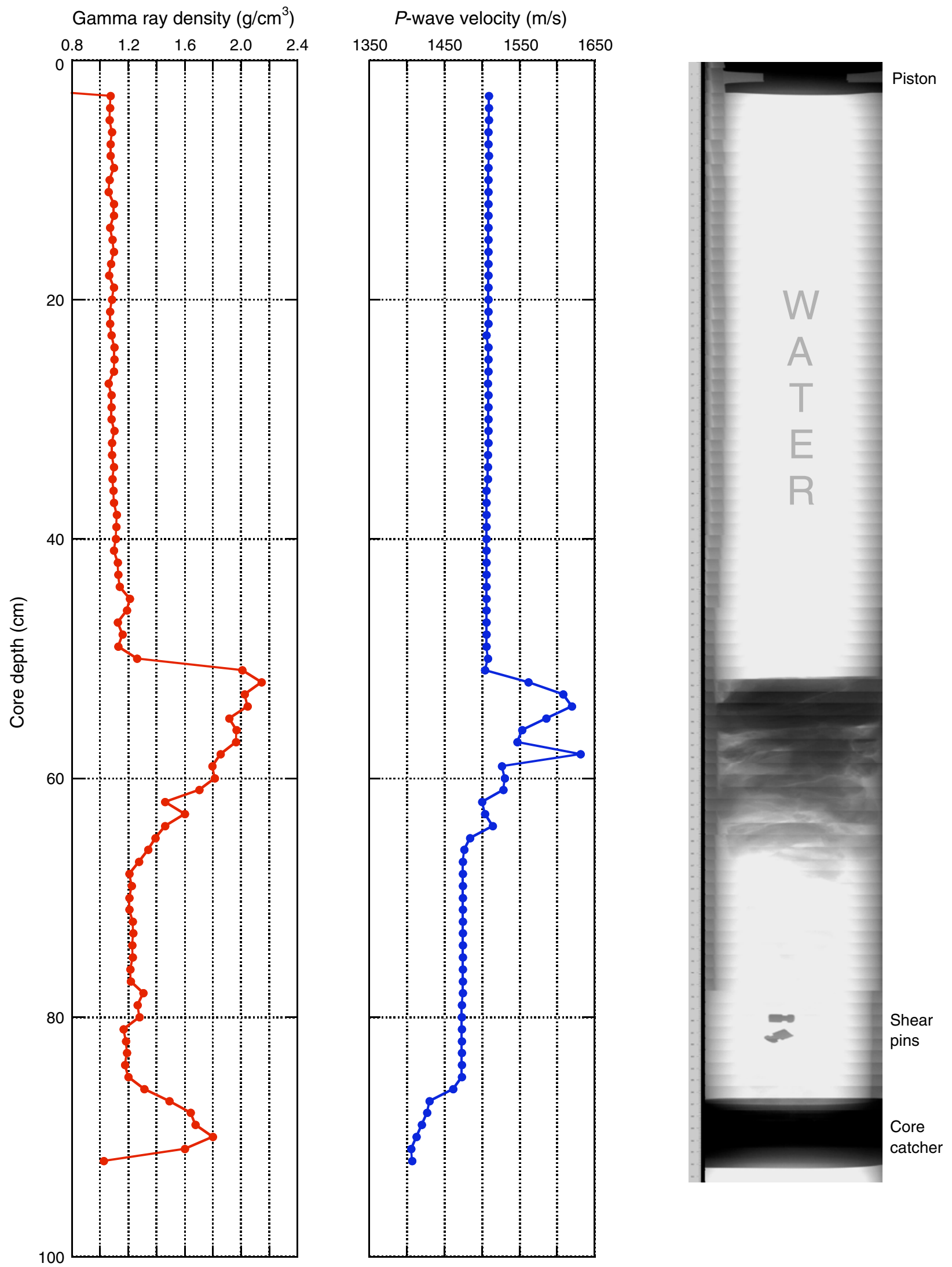
Figure F48. Gamma ray density vs. P-wave velocity for Core 311-U1326C-11Y. Data are also for Cores 311U1327D-12E, 14E, and 311-U1329E-9E, with the two interpreted gas hydrate-containing intervals highlighted in pink and green. The best-fit line to points showing a "normal" positive correlation between density and $P$ wave velocity is shown in blue. The red box encompasses anomalous high-velocity points.

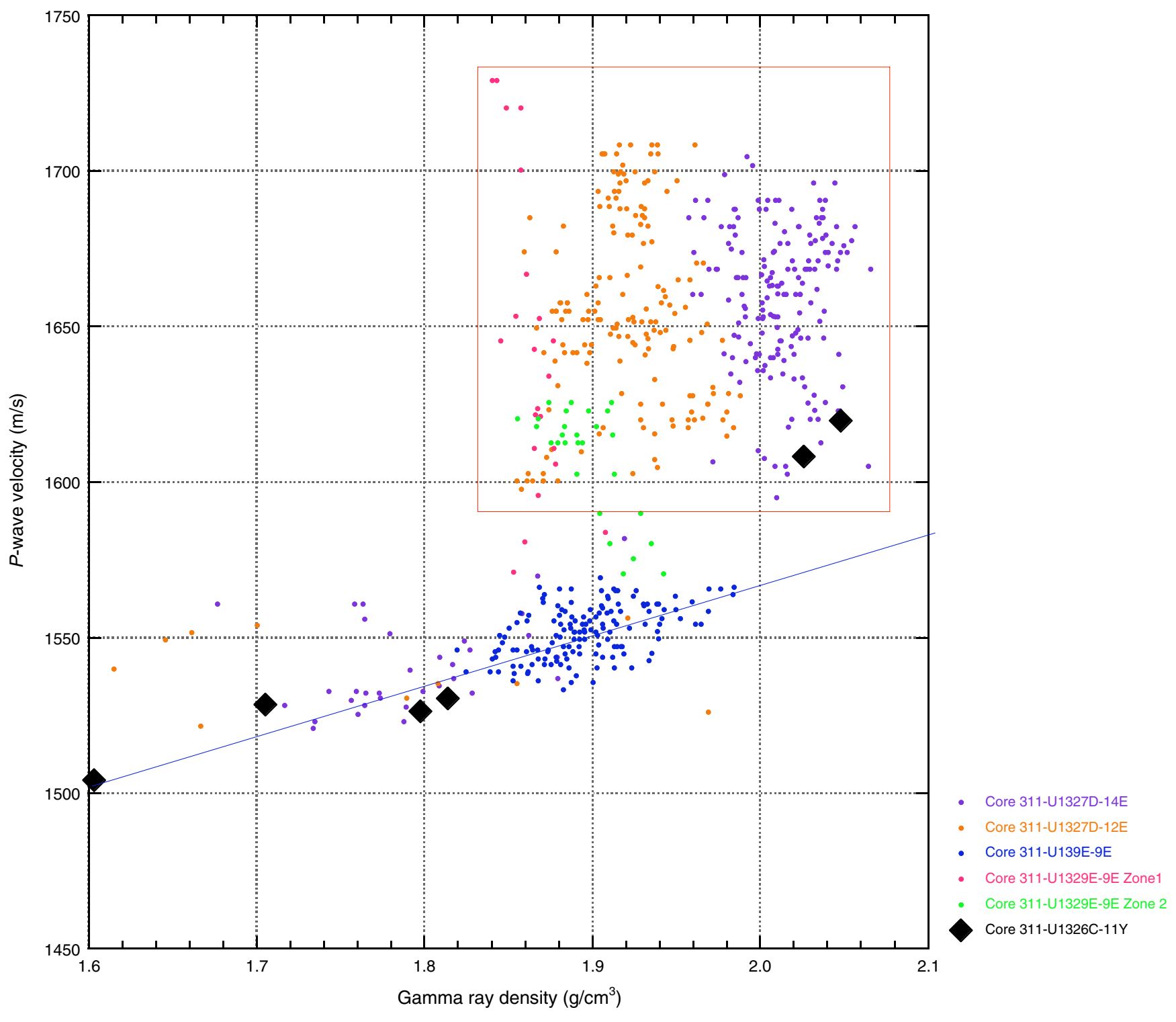


Figure F49. Monitoring and quality control LWD/MWD logs from Hole U1326A.

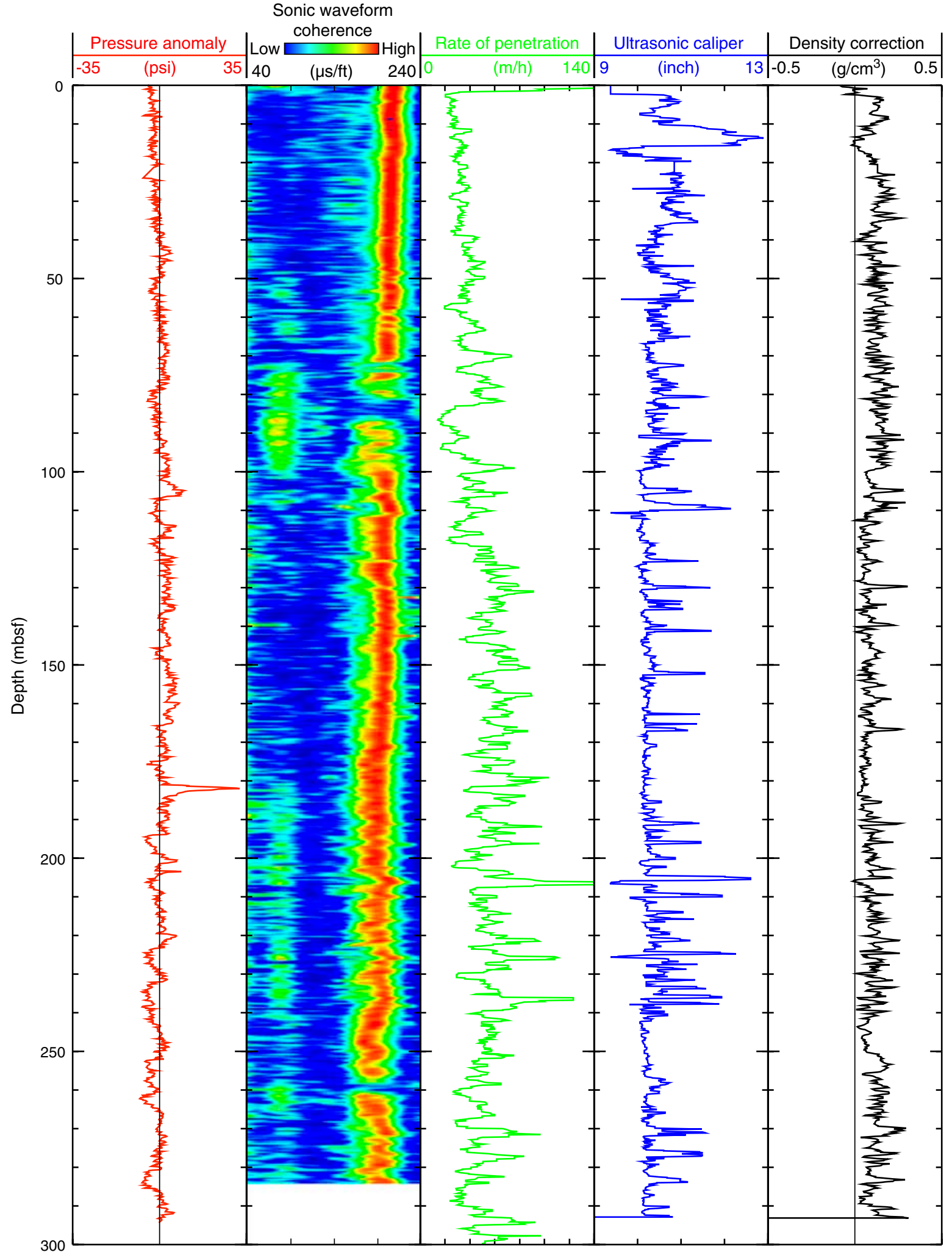


Figure F50. Summary of LWD data from Hole U1326A. Core recovery for Holes U1326C and U1326D are shown for reference. $\mathrm{P} 16 \mathrm{~B}=$ phase-shift resistivity measured by the EcoScope tool at a source-receiver spacing of 16 in $(41 \mathrm{~cm}), \mathrm{A} 40 \mathrm{~B}=$ attenuation resistivity measured by the EcoScope tool at a source-receiver spacing of 40 in $(102 \mathrm{~cm}), \mathrm{RAB}=$ resistivity-at-the-bit image obtained by the GeoVISION tool.

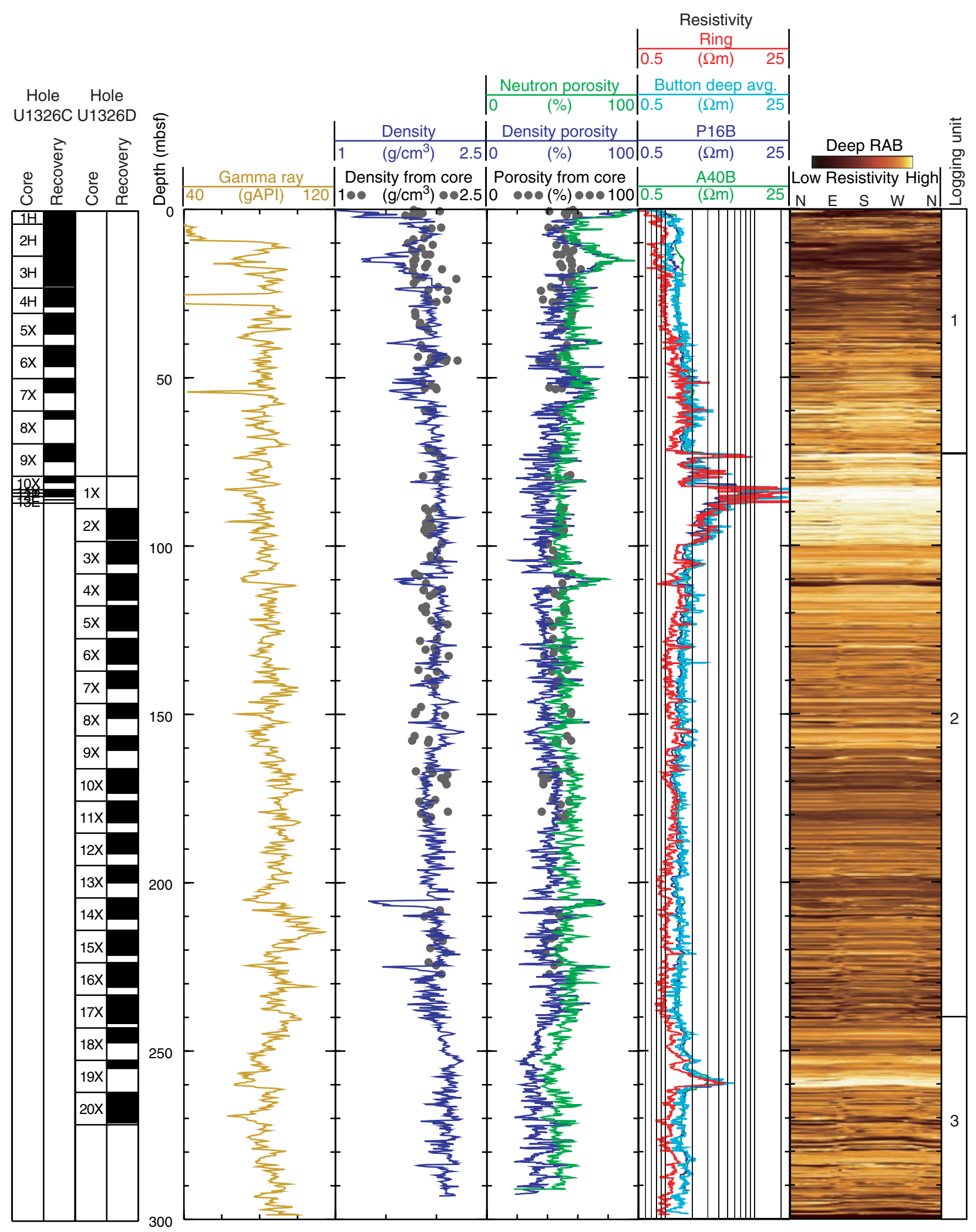


Figure F51. Summary of wireline logging data from Holes U1326C and U1326D. SFLU = spherically focused resistivity, $V_{\mathrm{p}}=P$-wave velocity, $V_{\mathrm{S}}=S$-wave velocity.

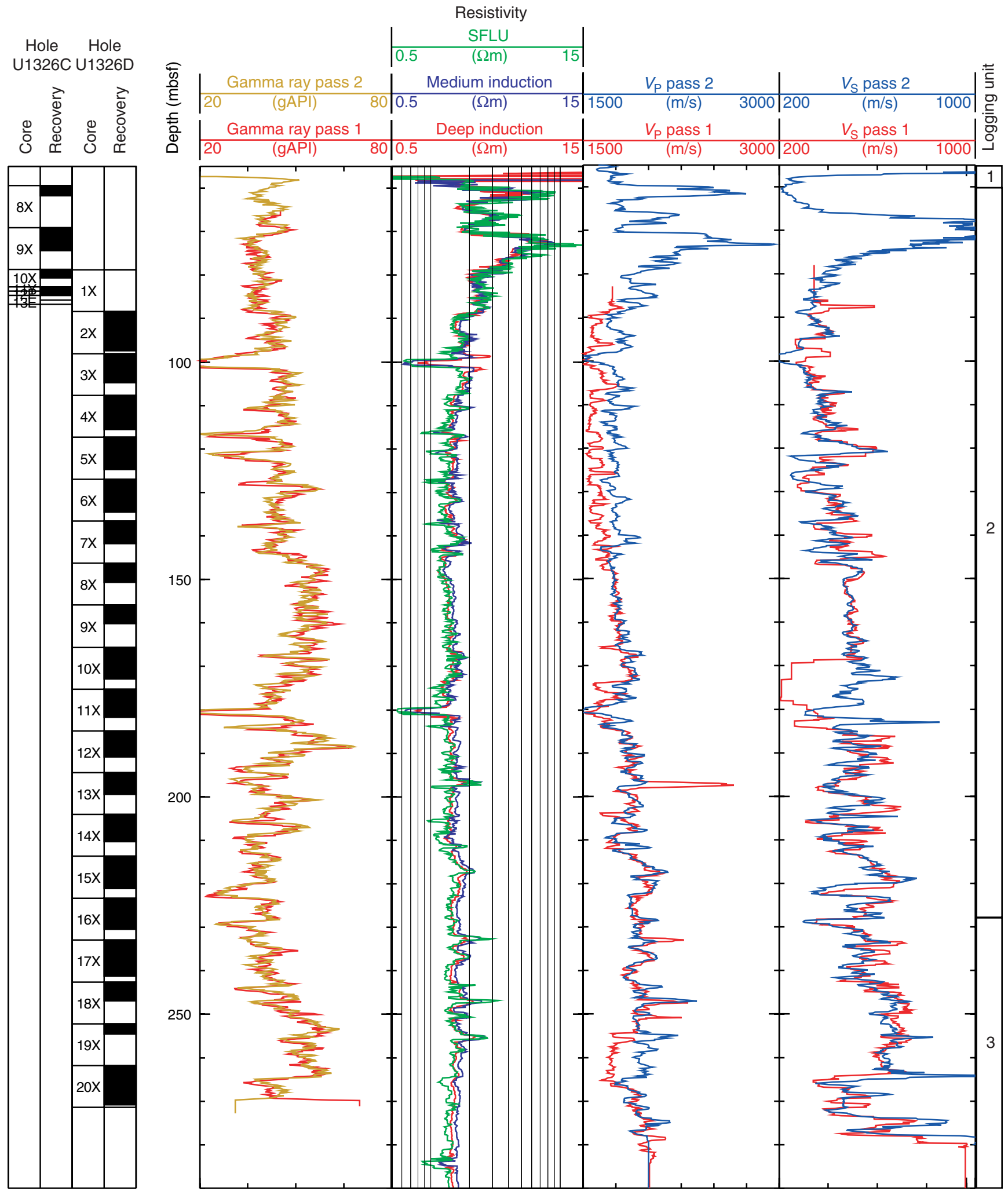


Figure F52. Sonic waveform data, $P$-wave velocity, and $S$-wave velocity obtained with the wireline Dipole Sonic Imager tool in Hole U1326D. $V_{\mathrm{p}}=P$-wave velocity, $V_{\mathrm{S}}=S$-wave velocity, $\mathrm{UD}=$ upper dipole, $\mathrm{LD}=$ lower dipole, mono. $=$ monopole.

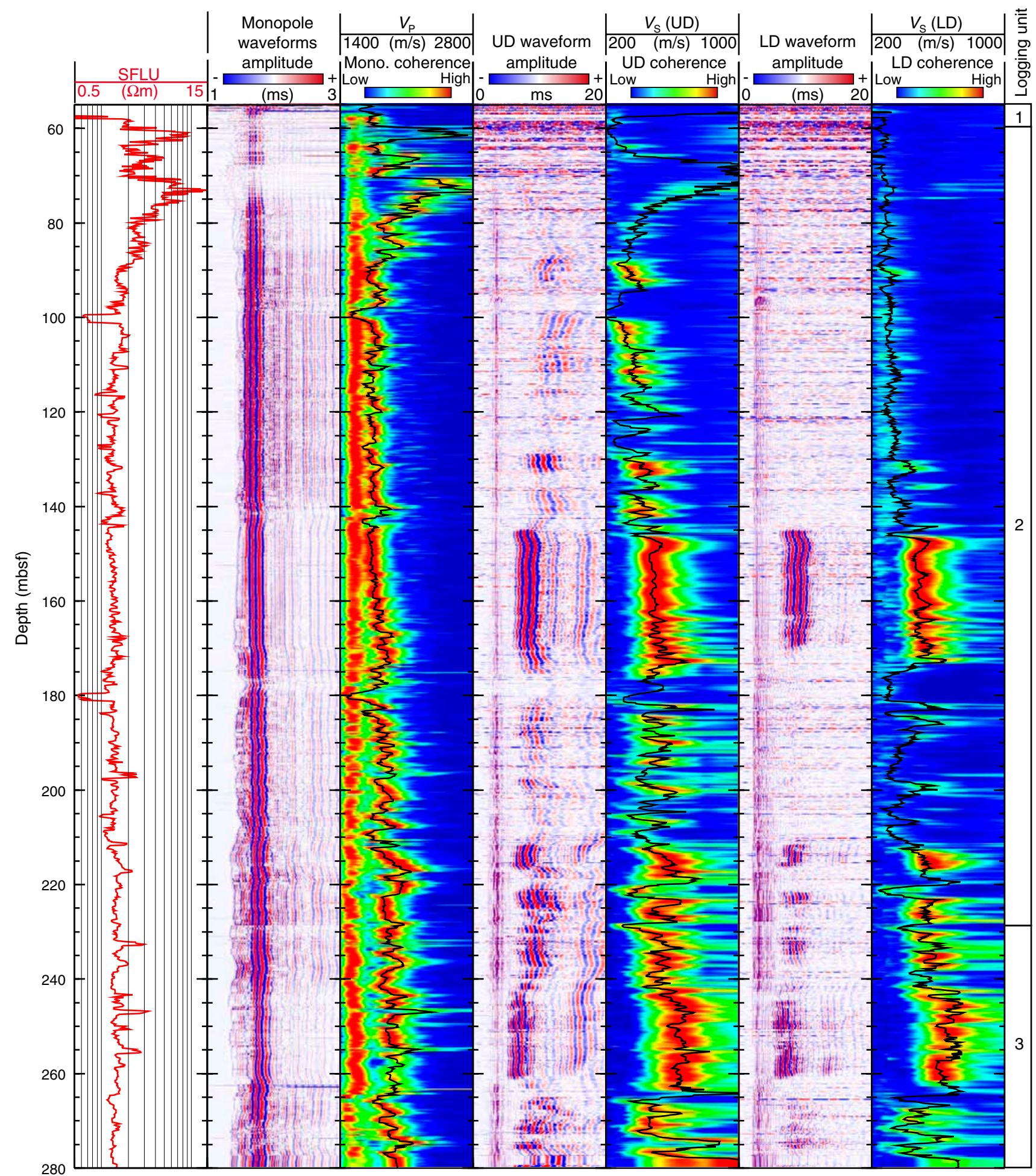


Figure F53. Comparison of logging-while-drilling (LWD; Hole U1326A) and wireline logging (WL; Hole U1326D) data. Core recovery for Holes U1326C and U1326D are shown for reference. P16B = phase-shift resistivity measured by the EcoScope tool at a source-receiver spacing of 16 in $(41 \mathrm{~cm})$, avg. = average.

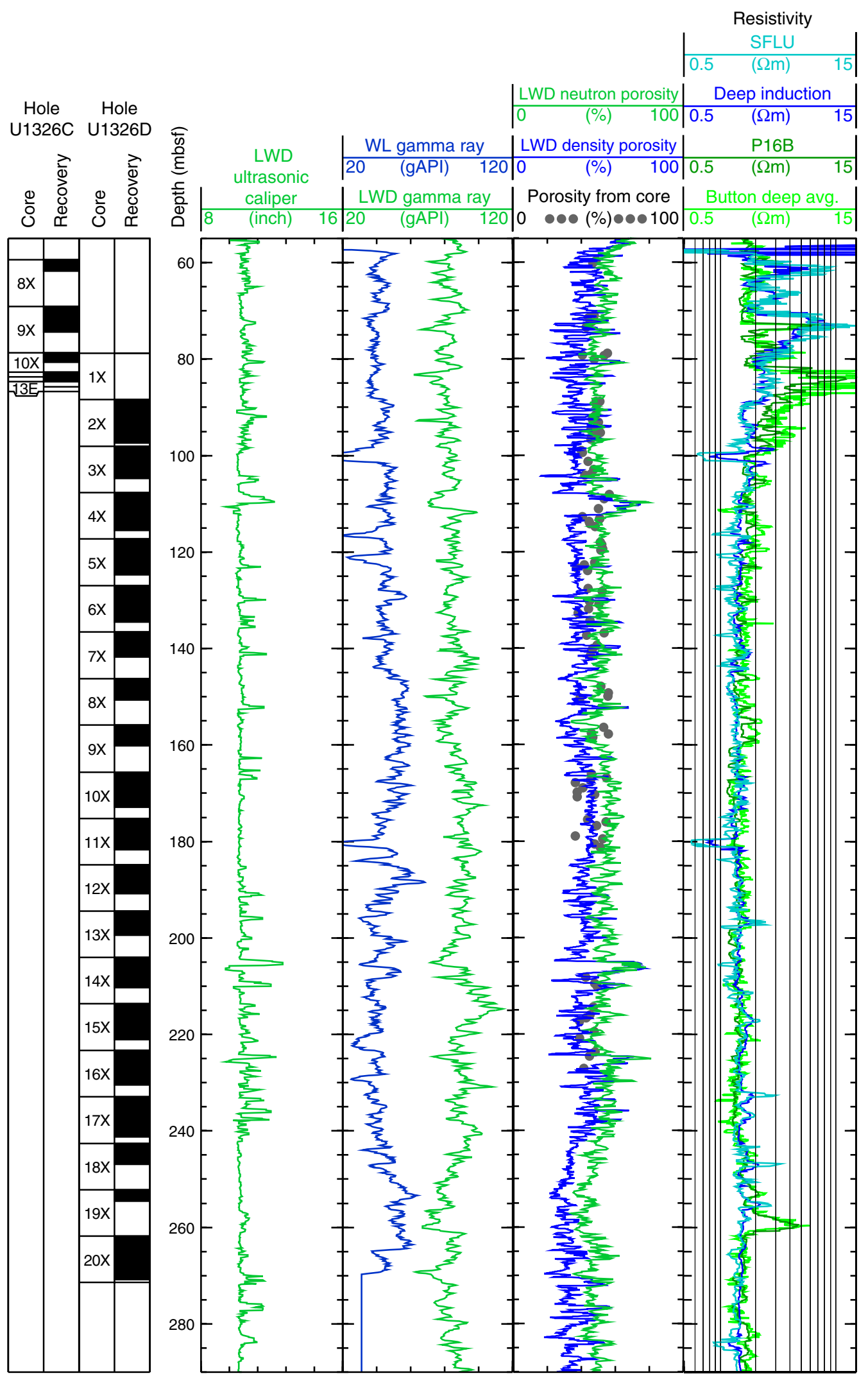


Figure F54. LWD image data from Hole U1326A. Core recovery for Holes U1326C and U1326D are shown for reference. $\mathrm{RAB}=$ resistivity-at-the-bit image obtained by the GeoVISION tool.

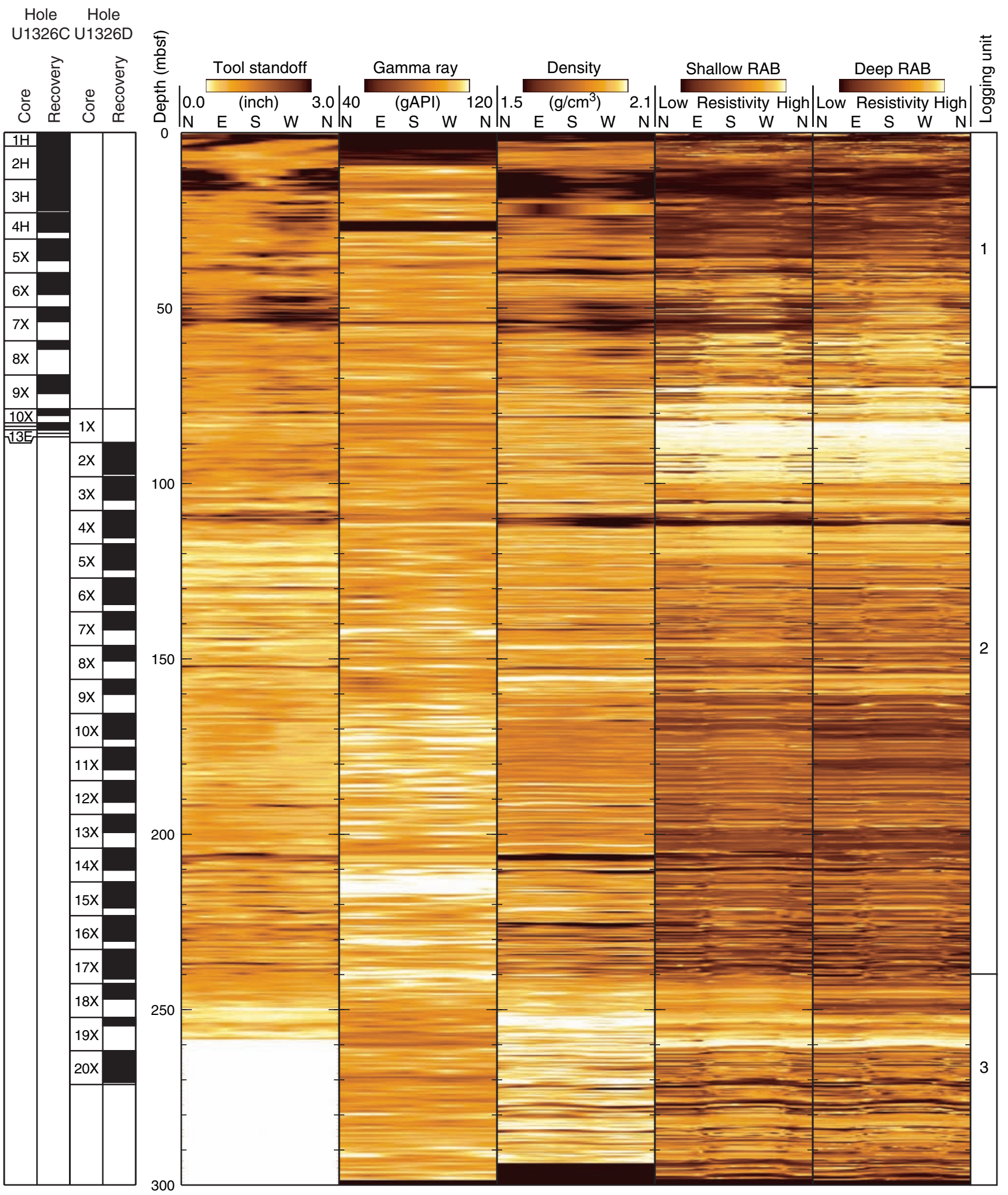


Figure F55. LWD resistivity images of layers in Hole U1326A. The "tadpoles" on the left show dip and azimuth of each layer, the fan plots show the azimuth of all layers in the intervals 95-145, 145-194, 194-243, and 243-293 mbsf. There is no systematic change of dip and azimuth with depth, and all layers dip to the north-northeast with dip angles of $45^{\circ}-85^{\circ}$. $\mathrm{RAB}=$ resistivity-at-the-bit image obtained by the GeoVISION tool.
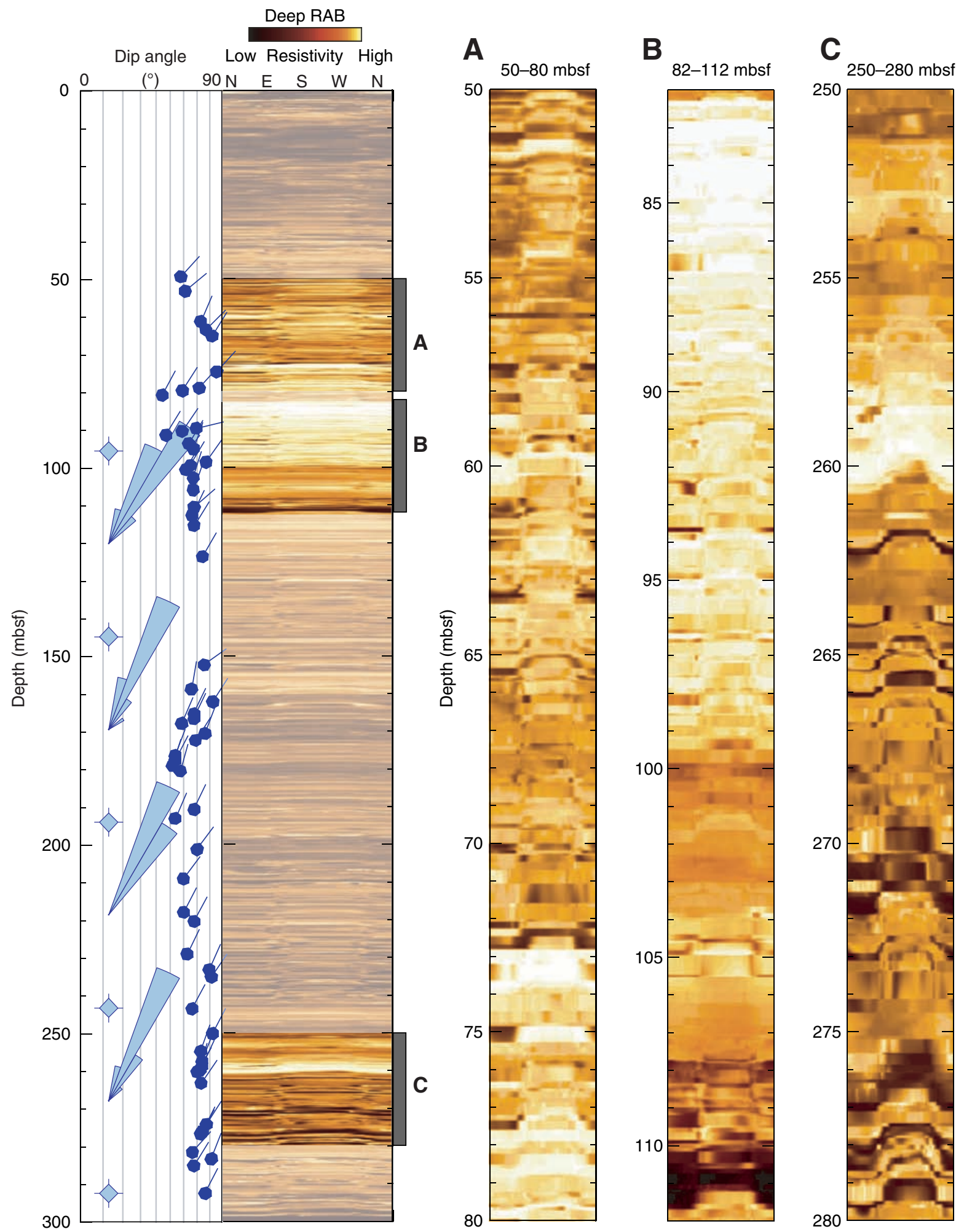
Figure F56. Comparison of LWD porosity logs with core-derived porosity data.

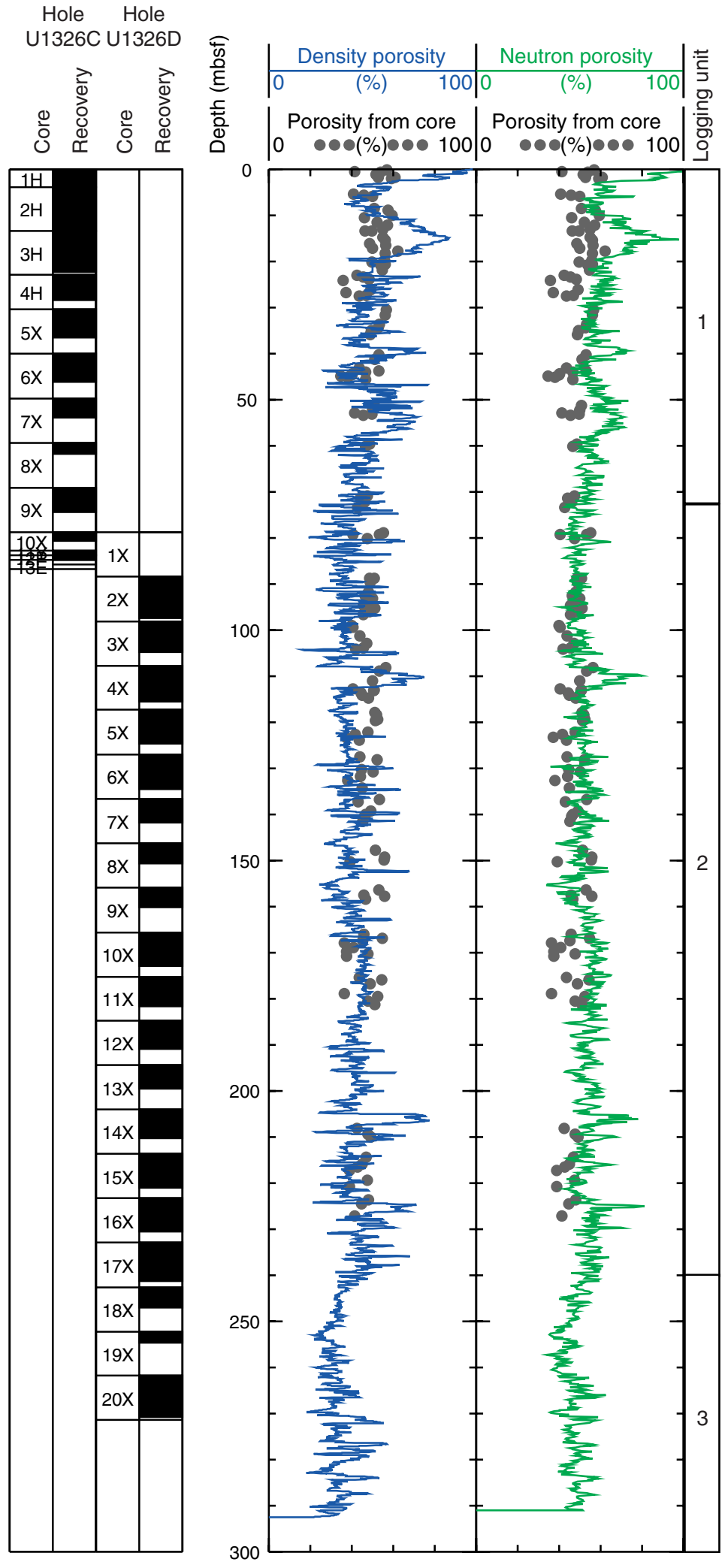


Figure F57. Water saturations from Archie's equation and LWD porosity and resistivity logs. The intervals marked in gray correspond to hole enlargements, where the measured density is erroneously low and the calculated water saturation is unreliable. $R_{\mathrm{w}}=$ formation water resistivity, $m=$ cementation coefficient, $R_{0}=$ computed formation resistivity for $100 \%$ water saturation, $R_{\mathrm{t}}=$ measured resistivity, $S_{\mathrm{w}}=$ water saturation, $\mathrm{RAB}=$ resistivity-at-the-bit image from the GeoVISION tool.

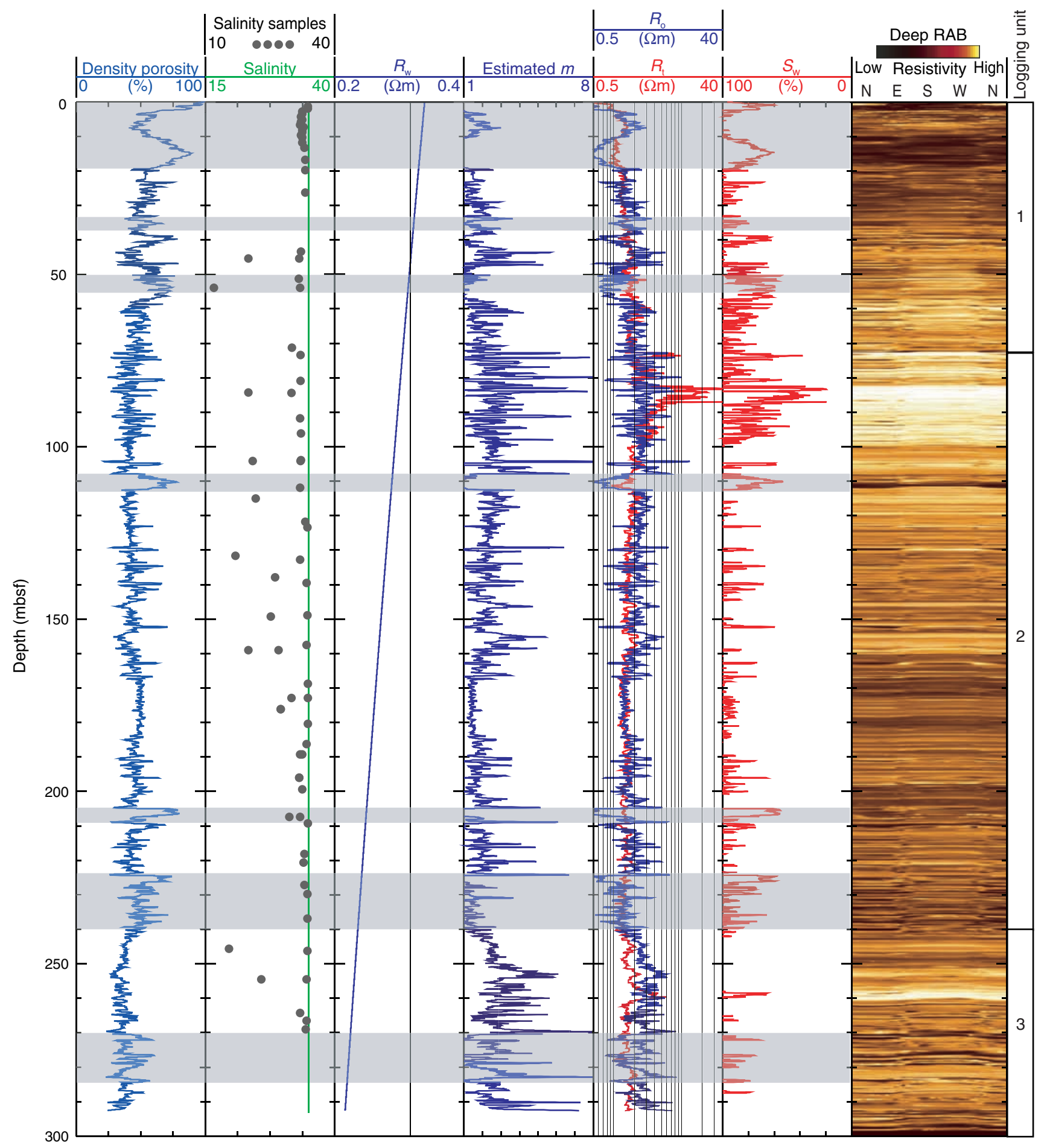


Figure F58. Comparison between LWD resistivity (Hole U1326A), wireline resistivity (Hole U1326D), and infrared (IR) images (Holes 1326C and 1326D). Note that the IR images from 0 to $88.4 \mathrm{mbsf}$ are from Hole U1326C, and the IR images from 88.4 to 300 mbsf are from Hole U1326D. RAB = resistivity-at-the-bit image obtained by the GeoVISION tool, P16B = EcoScope phase-shift resistivity, avg. = average, SFLU = spherically focused resistivity, Med. $=$ medium. White areas in the IR image indicate zones of no core recovery.

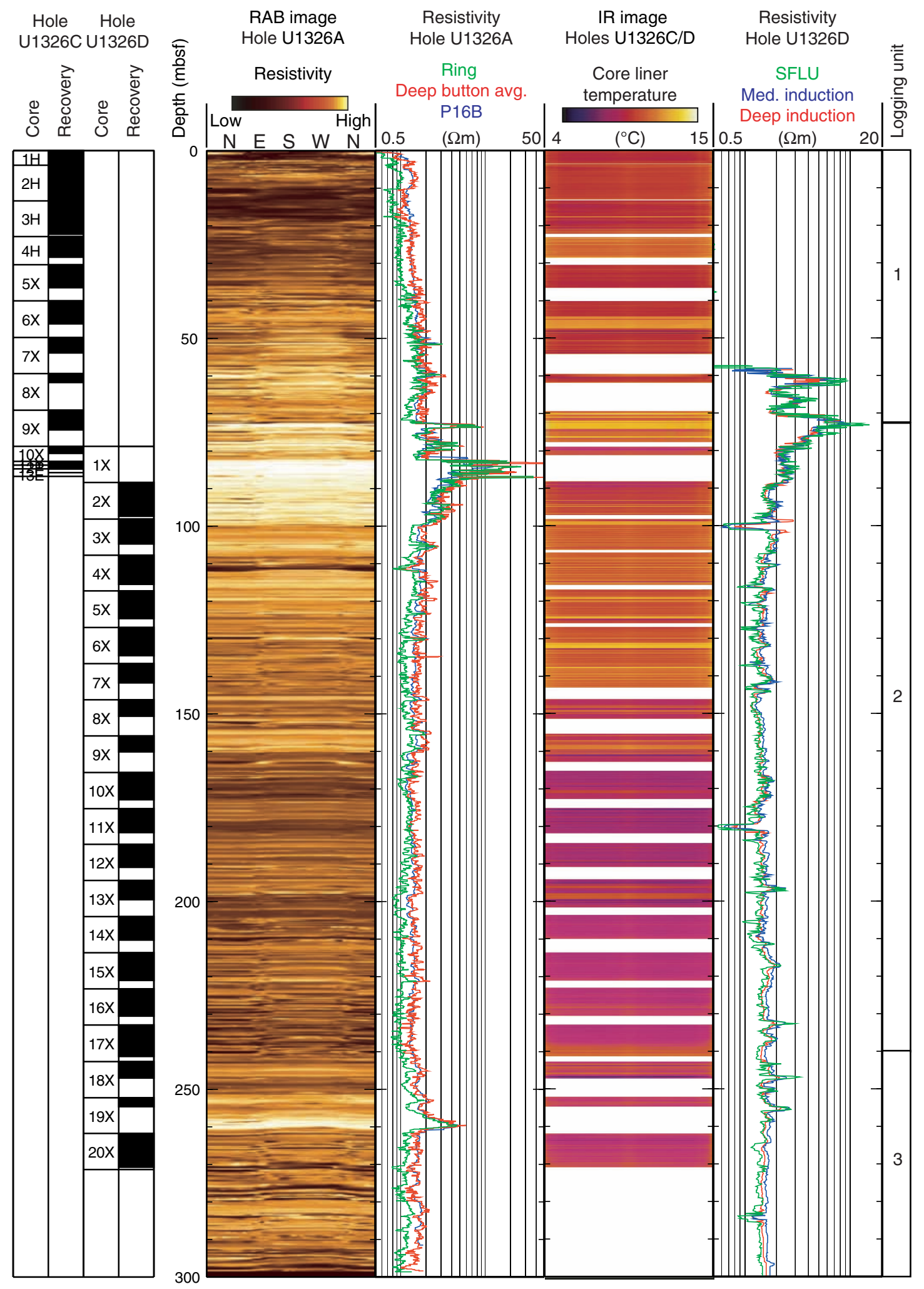


Table T1. Site U1326 coring summary. (See table note. Continued on next page.)

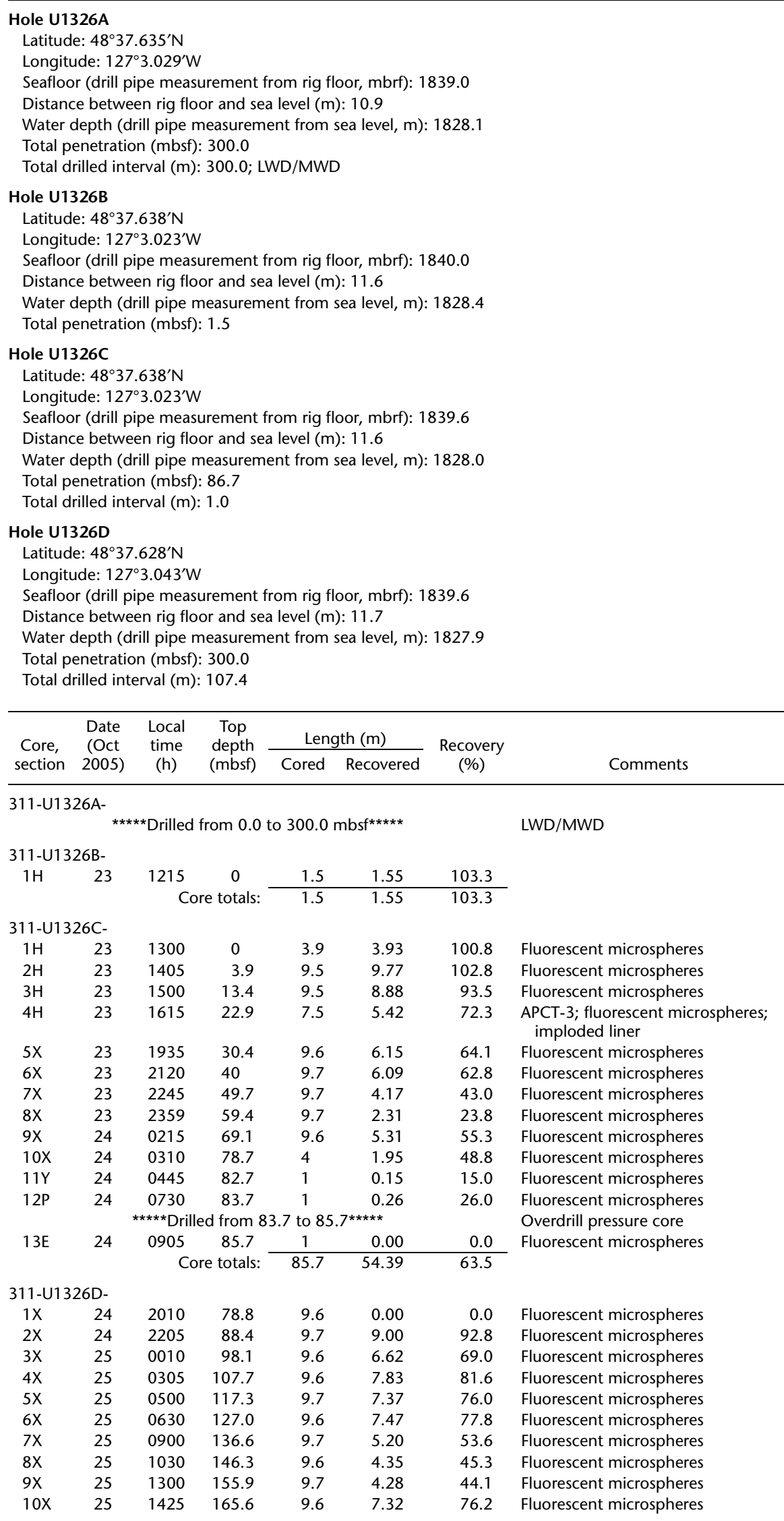


Table T1 (continued).

\begin{tabular}{|c|c|c|c|c|c|c|c|}
\hline \multirow{2}{*}{$\begin{array}{l}\text { Core, } \\
\text { section }\end{array}$} & \multirow{2}{*}{$\begin{array}{l}\text { Date } \\
\text { (Oct } \\
2005)\end{array}$} & \multirow{2}{*}{$\begin{array}{l}\text { Local } \\
\text { time } \\
\text { (h) }\end{array}$} & \multirow{2}{*}{$\begin{array}{c}\text { Top } \\
\text { depth } \\
\text { (mbsf) }\end{array}$} & \multicolumn{2}{|c|}{ Length $(\mathrm{m})$} & \multirow{2}{*}{$\begin{array}{l}\text { Recovery } \\
\text { (\%) }\end{array}$} & \multirow[b]{2}{*}{ Comments } \\
\hline & & & & Cored & Recovered & & \\
\hline $11 \mathrm{X}$ & 25 & 1555 & 175.2 & 9.6 & 6.46 & 67.3 & Fluorescent microspheres \\
\hline $12 \mathrm{X}$ & 25 & 1730 & 184.8 & 9.6 & 6.04 & 62.9 & Fluorescent microspheres \\
\hline $13 x$ & 25 & 1910 & 194.4 & 9.6 & 5.04 & 52.5 & Fluorescent microspheres \\
\hline $14 X$ & 25 & 2100 & 204.0 & 9.6 & 6.29 & 65.5 & Fluorescent microspheres \\
\hline $15 \mathrm{X}$ & 25 & 2225 & 213.6 & 9.7 & 7.46 & 76.9 & Fluorescent microspheres \\
\hline $16 \mathrm{X}$ & 25 & 2355 & 223.3 & 9.6 & 7.14 & 74.4 & Fluorescent microspheres \\
\hline $17 X$ & 26 & 0130 & 232.9 & 9.7 & 8.35 & 86.1 & Fluorescent microspheres \\
\hline $18 x$ & 26 & 0320 & 242.6 & 9.6 & 4.36 & 45.4 & $\begin{array}{l}\text { DVTP at } 252.2 \text { mbsf; fluorescent } \\
\text { microspheres }\end{array}$ \\
\hline $19 \mathrm{X}$ & 26 & 0645 & 252.2 & 9.6 & 2.39 & 24.9 & Fluorescent microspheres \\
\hline $20 x$ & 26 & 0900 & 261.8 & 9.6 & 8.99 & 93.6 & $\begin{array}{l}\text { DVTP at } 271.4 \text { mbsf; fluorescent } \\
\text { microspheres }\end{array}$ \\
\hline \multicolumn{7}{|c|}{ 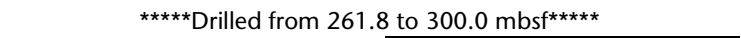 } & DVTP at $300.0 \mathrm{mbsf}$ \\
\hline & & & re totals: & 192.6 & 121.96 & 63.3 & \\
\hline
\end{tabular}

Note: LWD/MWD = logging while drilling/measurement while drilling, APCT-3 = third-generation advanced piston corer temperature tool, DVTP = Davis-Villinger Temperature Probe. 


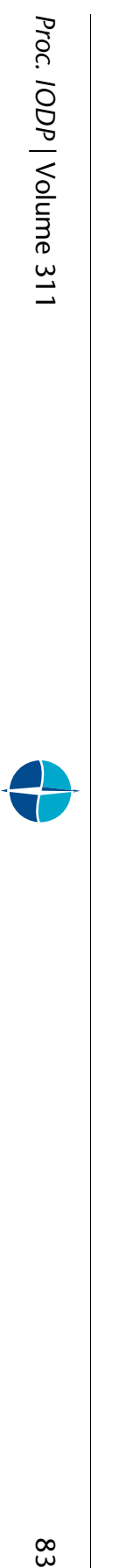

Table T2. Occurrence of diatoms, Holes U1326B, U1326C, and U1326D. (See table notes. Continued on next page.)

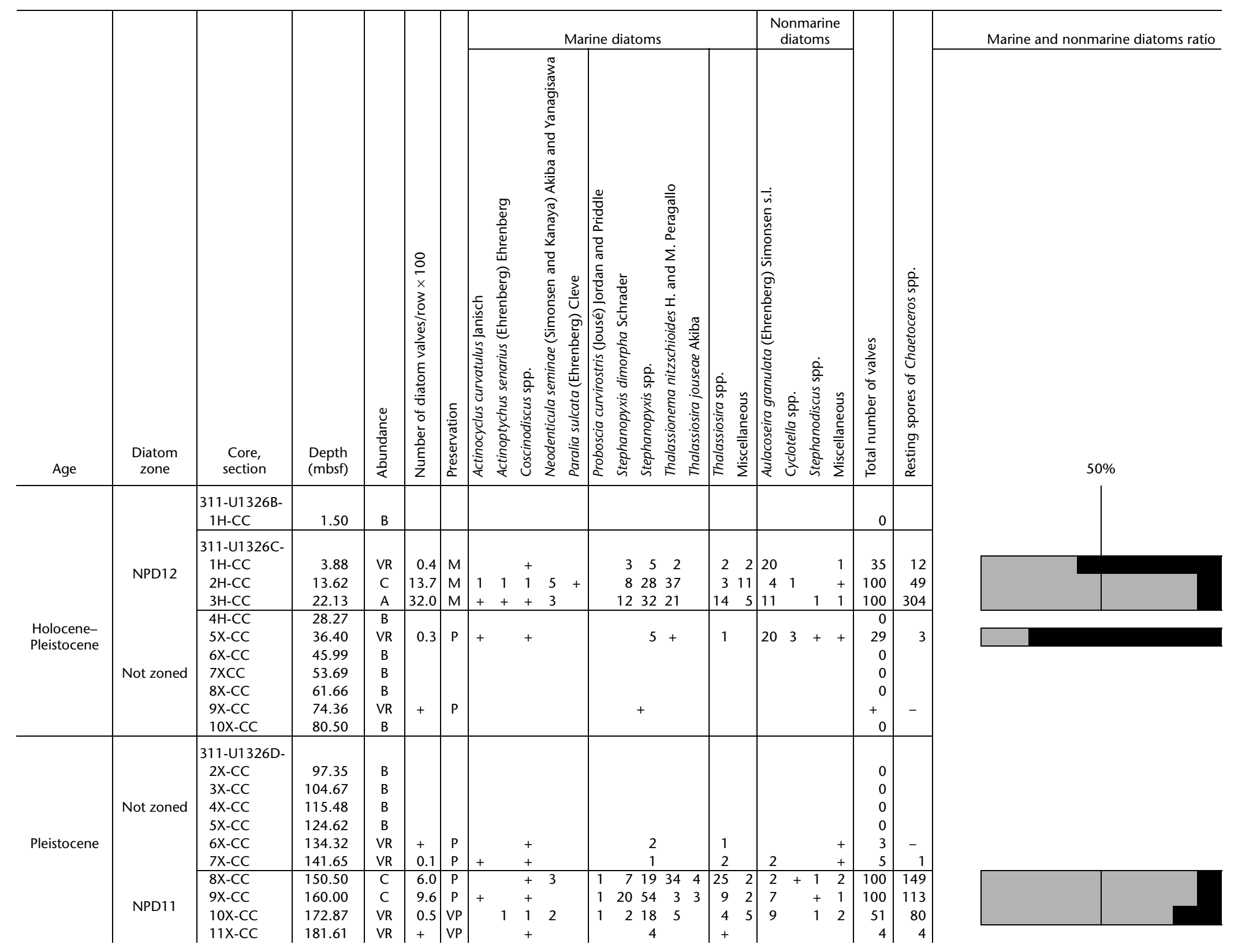


Table T2 (continued).

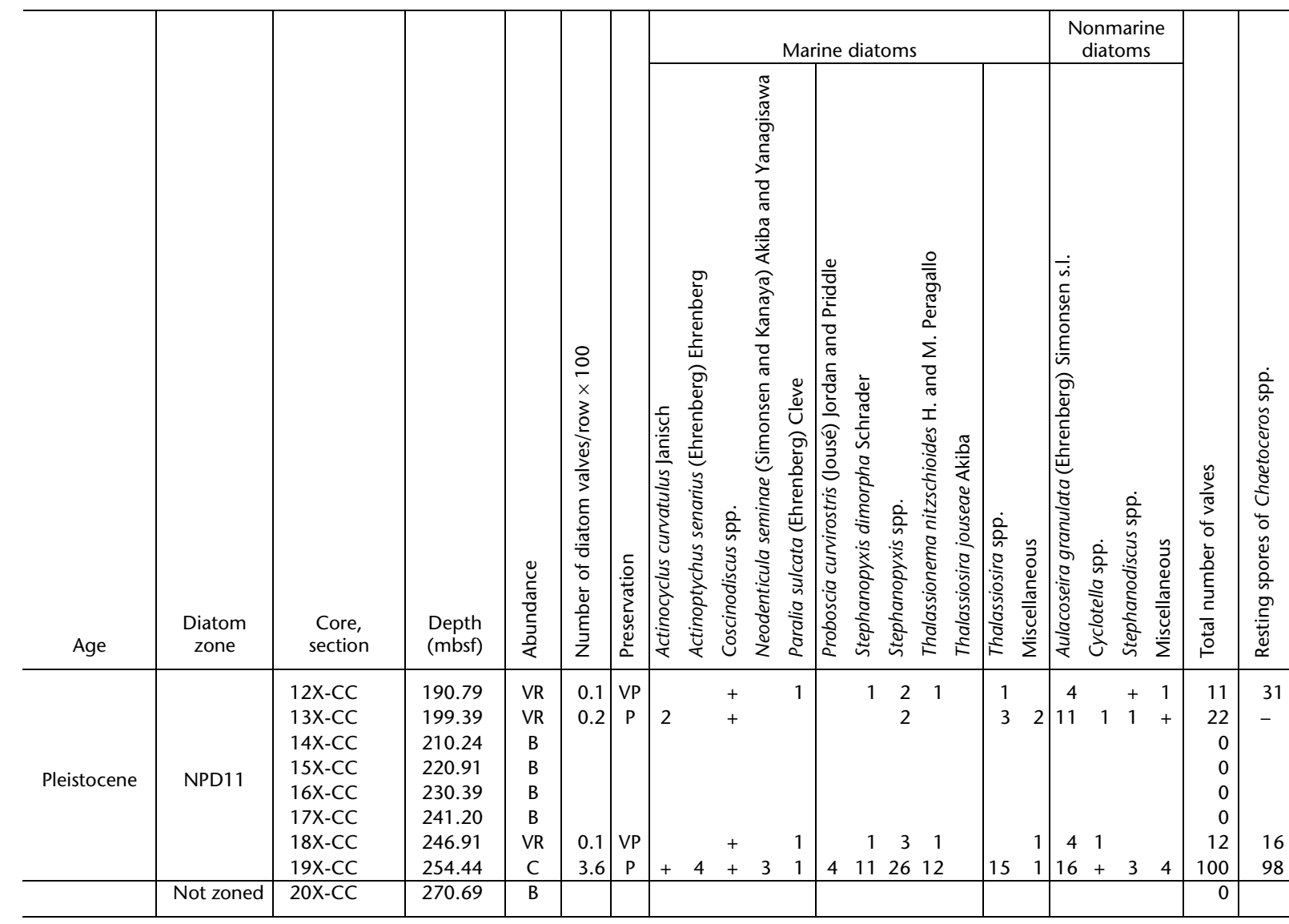

Marine and nonmarine diatoms ratio

\begin{tabular}{|c|c|c|c|c|c|c|c|c|c|c|c|c|c|c|c|c|c|c|c|c|}
\hline Age & zone & section & (mbsf) & $\frac{0}{4}$ & ž & 递 & E & $\tilde{u}$ & के & $\stackrel{2}{2}$ & 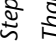 & $\xi$ & $\frac{8}{h}$ & $\sum$ & 妾 & ડे & & & $\stackrel{\circ}{\circ}$ & $\ddot{\ddot{~}}$ \\
\hline \multirow{9}{*}{ Pleistocene } & \multirow{8}{*}{ NPD11 } & $12 \mathrm{X}-\mathrm{CC}$ & 190.79 & VR & 0.1 & VP & & + & 1 & 1 & 2 & 1 & 1 & & 4 & & + & 1 & 11 & 31 \\
\hline & & $13 \mathrm{X}-\mathrm{CC}$ & 199.39 & VR & 0.2 & $P$ & 2 & + & & & 2 & & 3 & 2 & 11 & 1 & 1 & + & 22 & - \\
\hline & & $14 \mathrm{X}-\mathrm{CC}$ & 210.24 & B & & & & & & & & & & & & & & & 0 & \\
\hline & & $15 \mathrm{X}-\mathrm{CC}$ & 220.91 & B & & & & & & & & & & & & & & & 0 & \\
\hline & & $16 \mathrm{X}-\mathrm{CC}$ & 230.39 & B & & & & & & & & & & & & & & & 0 & \\
\hline & & $17 X-C C$ & 241.20 & B & & & & & & & & & & & & & & & 0 & \\
\hline & & $18 \mathrm{X}-\mathrm{CC}$ & 246.91 & VR & 0.1 & VP & & + & 1 & 1 & 3 & 1 & & 1 & 4 & 1 & & & 12 & 16 \\
\hline & & 19X-CC & 254.44 & C & 3.6 & $P$ & +4 & +3 & 1 & $4 \quad 11$ & 261 & 12 & 15 & 1 & 16 & + & 3 & 4 & 100 & 98 \\
\hline & Not zoned & $20 \mathrm{X}-\mathrm{CC}$ & 270.69 & $B$ & & & & & & & & & & & & & & & 0 & \\
\hline
\end{tabular}

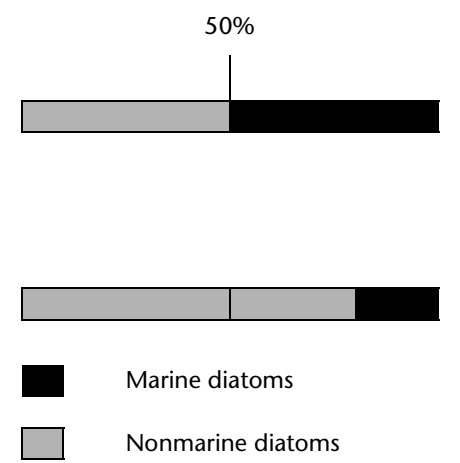

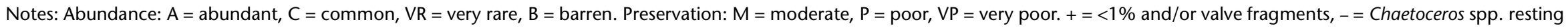
spores not present. 
Table T3. Concentrations of solutes in interstitial waters, Site U1326. (See table notes. Continued on next page.)

\begin{tabular}{|c|c|c|c|c|c|c|c|c|c|c|c|c|c|c|c|c|c|c|c|}
\hline \multirow{2}{*}{$\begin{array}{l}\text { Core, section, } \\
\text { interval }(\mathrm{cm})\end{array}$} & \multirow{2}{*}{$\begin{array}{l}\text { Depth } \\
\text { (mbsf) }\end{array}$} & \multirow{2}{*}{$\begin{array}{l}\text { Volume } \\
(\mathrm{mL})\end{array}$} & \multirow[b]{2}{*}{$\mathrm{pH}$} & \multirow{2}{*}{$\begin{array}{l}\text { Alkalinity } \\
(\mathrm{mM})\end{array}$} & \multirow[b]{2}{*}{ Salinity } & \multirow{2}{*}{$\underset{(\mathrm{mM})}{\mathrm{Cl}}$} & \multirow{2}{*}{$\begin{array}{c}\mathrm{SO}_{4} \\
(\mathrm{mM})\end{array}$} & \multirow{2}{*}{$\begin{array}{l}\mathrm{PO}_{4} \\
(\mu \mathrm{M})\end{array}$} & \multirow{2}{*}{$\begin{array}{l}\mathrm{NH}_{4} \\
(\mathrm{mM})\end{array}$} & \multirow{2}{*}{$\begin{array}{c}\mathrm{H}_{4} \mathrm{SiO}_{4} \\
(\mu \mathrm{M})\end{array}$} & \multicolumn{4}{|c|}{ Cations (mM) } & \multirow[b]{2}{*}{$\mathrm{Mg} / \mathrm{Ca}$} & & ace eler & ents $(\mu \mathrm{M}$ & \\
\hline & & & & & & & & & & & $\mathrm{Na}$ & $\mathrm{K}$ & $\mathrm{Mg}$ & $\mathrm{Ca}$ & & $\mathrm{Sr}$ & $\mathrm{Li}$ & B & $\mathrm{Ba}$ \\
\hline 311-U1326C- & & & & & & & & & & & & & & & & & & & \\
\hline $1 \mathrm{H}-1,65-80$ & 0.7 & 60.0 & 7.98 & 6.0 & 33.8 & 559.0 & 21.4 & 7.2 & 0.3 & 385.3 & 436.8 & 11.1 & 46.8 & 8.4 & 5.6 & 77.9 & 14.8 & 567.1 & 0.0 \\
\hline $1 \mathrm{H}-1,135-150$ & 1.4 & 62.0 & 8.19 & 13.1 & 33.8 & 562.5 & 13.1 & 23.0 & 0.4 & 531.2 & 428.9 & 11.0 & 46.6 & 5.9 & 7.9 & 61.1 & 12.4 & 492.0 & 0.0 \\
\hline $1 \mathrm{H}-2,65-80$ & 2.2 & 53.0 & 8.19 & 19.8 & 32.5 & 567.4 & 3.4 & 29.7 & 0.5 & 693.6 & 444.5 & 10.8 & 43.1 & 4.5 & 9.6 & 56.6 & 9.1 & 376.3 & 0.3 \\
\hline $1 \mathrm{H}-2,135-150$ & 2.9 & 67.0 & 8.11 & 23.1 & 32.5 & 566.9 & 0.0 & 34.7 & 0.7 & 751.5 & 428.4 & 10.1 & 40.0 & 4.4 & 9.0 & 71.3 & 7.3 & 511.1 & 6.7 \\
\hline $1 \mathrm{H}-3,60-72$ & 3.7 & 44.0 & 8.21 & 19.2 & 32.2 & 566.4 & 0.0 & 57.2 & 0.9 & 748.8 & 425.3 & 10.3 & 38.0 & 3.5 & 10.9 & 50.4 & 5.4 & 294.4 & 11.1 \\
\hline $2 \mathrm{H}-1,60-75$ & 4.6 & 36.0 & 8.17 & 14.9 & 32.5 & 566.4 & 7.6 & 38.8 & 0.5 & 709.6 & 423.8 & 10.2 & 39.8 & 4.9 & 8.1 & 73.7 & 8.8 & 499.3 & 3.7 \\
\hline $2 \mathrm{H}-1,135-150$ & 5.3 & 50.0 & 8.05 & 19.2 & 32.2 & 566.9 & 0.3 & 66.3 & 1.0 & 739.4 & 433.1 & 9.5 & 41.4 & 3.9 & 10.6 & 73.3 & 2.6 & 504.6 & 18.6 \\
\hline $2 \mathrm{H}-2,65-80$ & 6.1 & 54.0 & 8.02 & 19.1 & 32.0 & 566.9 & 0.1 & 71.3 & 1.1 & 732.6 & 415.9 & 9.3 & 42.2 & 4.0 & 10.4 & 77.0 & 1.5 & 453.8 & 20.9 \\
\hline $2 \mathrm{H}-2,135-150$ & 6.8 & 50.0 & 7.97 & 19.0 & 32.8 & 567.9 & 0.0 & 81.3 & 1.3 & 606.2 & 422.9 & 9.1 & 42.3 & 4.4 & 9.6 & 78.1 & 0.0 & 471.7 & 31.0 \\
\hline $2 \mathrm{H}-3,60-75$ & 7.6 & 54.0 & 7.97 & 18.5 & 32.5 & 564.9 & 0.2 & 71.3 & 1.5 & 628.0 & 416.5 & 8.9 & 33.7 & 4.0 & 8.4 & 75.2 & 0.7 & 444.8 & 25.3 \\
\hline $2 \mathrm{H}-3,135-150$ & 8.3 & 53.0 & 7.99 & 19.1 & 32.5 & 566.4 & 0.1 & 77.2 & 1.5 & 738.3 & 425.2 & 8.9 & 39.3 & 3.5 & 11.3 & 79.2 & 0.3 & 481.9 & 19.8 \\
\hline $2 \mathrm{H}-4,65-80$ & 9.1 & 58.0 & 8.11 & 19.5 & 32.2 & 564.9 & 0.0 & 73.0 & 1.8 & 647.7 & 388.0 & 8.9 & 37.3 & 3.7 & 10.0 & 76.0 & 0.0 & 470.1 & 29.1 \\
\hline $2 \mathrm{H}-4,135-150$ & 9.8 & 44.0 & 8.00 & 19.7 & 32.5 & 566.9 & 0.0 & 71.3 & 1.9 & 768.8 & 381.1 & 8.4 & 39.5 & 3.7 & 10.8 & 75.9 & 1.5 & 483.5 & 22.5 \\
\hline $2 \mathrm{H}-5,135-150$ & 11.3 & 46.0 & 7.98 & 18.8 & 32.5 & 564.9 & 0.0 & 40.5 & 1.9 & 649.4 & 414.3 & 9.4 & 29.3 & 4.3 & 6.8 & 79.4 & 0.4 & 466.6 & 31.7 \\
\hline $2 \mathrm{H}-6,135-150$ & 12.8 & 48.0 & 7.84 & 18.4 & 33.0 & 565.4 & 0.0 & 34.7 & 2.0 & 710.9 & 439.1 & 8.4 & 37.9 & 4.9 & 7.8 & 77.5 & 1.2 & 423.9 & 31.5 \\
\hline $3 \mathrm{H}-2,135-150$ & 16.3 & 44.0 & 7.75 & 18.6 & 33.2 & 565.9 & 0.1 & 22.2 & 2.6 & 703.5 & 404.8 & 8.2 & 40.9 & 4.9 & 8.3 & 71.9 & 2.4 & 436.7 & 34.3 \\
\hline $3 \mathrm{H}-4,135-150$ & 19.3 & 50.0 & 7.80 & 17.8 & 33.2 & 566.9 & 0.1 & 21.3 & 2.9 & 638.6 & 396.9 & 8.3 & 43.7 & 5.5 & 7.9 & 75.2 & 3.1 & 414.5 & 34.4 \\
\hline $4 \mathrm{H}-2,130-150$ & 25.8 & 38.0 & 8.03 & 19.7 & 33.2 & 566.9 & 0.0 & 14.7 & 2.9 & 271.4 & 401.0 & 7.9 & 39.5 & 5.2 & 7.6 & 83.2 & 0.0 & 395.1 & 20.6 \\
\hline $5 X-2,117-142^{*}$ & 33.2 & - & - & - & - & - & - & - & - & - & - & - & - & - & - & - & - & - & - \\
\hline $5 X-5,0-35^{*}$ & 36.2 & - & - & - & - & - & - & - & - & - & - & - & - & - & - & - & - & - & - \\
\hline $6 \mathrm{X}-2,125-150$ & 42.9 & 18.0 & 8.02 & 7.6 & 32.2 & 569.9 & 2.1 & 3.7 & 2.4 & 299.8 & 417.8 & 7.2 & 33.7 & 7.0 & 4.8 & 82.3 & 0.0 & 416.7 & 11.0 \\
\hline $6 X-4,83-96$ & 44.9 & 2.0 & - & - & 5.0 & 96.4 & 0.4 & 3.7 & 0.3 & - & - & - & - & - & - & - & - & - & - \\
\hline $6 X-4,83-96$ & 44.9 & 3.0 & - & - & 31.8 & 556.5 & 0.8 & 1.2 & 2.2 & - & - & - & - & - & - & - & - & - & - \\
\hline $6 X-4,83-96$ & 44.9 & 7.0 & - & - & 20.0 & 345.4 & 7.3 & - & 1.1 & 172.3 & 260.4 & 4.6 & 22.0 & 5.2 & 4.2 & 43.8 & 4.3 & 209.7 & 5.1 \\
\hline $7 X-1,93-133$ & 50.8 & 9.0 & 7.99 & 4.6 & 31.7 & 570.7 & 2.1 & 2.8 & 2.2 & 214.8 & 425.0 & 6.6 & 35.2 & 9.1 & 3.9 & 86.3 & 1.6 & 427.0 & 13.2 \\
\hline $7 X-3,74-101$ & 53.4 & 7.0 & - & - & 12.0 & 570.9 & 3.0 & 2.0 & 0.8 & 298.8 & 413.6 & 6.1 & 33.0 & 10.0 & 3.3 & 92.4 & 1.5 & 317.9 & 14.7 \\
\hline $7 X-3,74-101$ & 53.4 & 8.5 & - & - & 32.0 & 212.1 & 0.0 & 1.2 & 1.9 & - & - & - & - & - & - & - & - & - & - \\
\hline $9 X-2,0-25$ & 70.7 & 34.0 & 8.24 & 2.6 & 30.1 & 563.9 & 5.2 & 1.2 & 1.5 & 180.4 & 425.7 & 5.7 & 26.1 & 17.3 & 1.5 & 91.2 & 0.0 & 415.8 & 13.4 \\
\hline $9 X-3,66-91$ & 72.9 & 23.0 & 8.17 & 2.7 & 32.1 & 570.0 & 1.2 & 1.2 & 1.7 & 172.9 & 434.7 & 5.9 & 24.8 & 15.0 & 1.7 & 91.3 & 0.0 & 401.4 & 14.4 \\
\hline $10 \times-2,0-30$ & 80.4 & 7.0 & - & - & 32.1 & 570.0 & 0.1 & 1.2 & 1.8 & 363.9 & 413.4 & 5.4 & 25.8 & 17.2 & 1.5 & 87.8 & 0.0 & 407.6 & 14.9 \\
\hline $12 \mathrm{P}-1,3-14$ & 83.8 & 16.0 & - & - & 20.0 & 522.0 & 10.8 & - & - & - & - & - & - & - & - & - & - & - & - \\
\hline $12 \mathrm{P}-1,14-24$ & 83.9 & 8.0 & - & - & 30.0 & 522.0 & 9.7 & - & - & - & - & - & - & - & - & - & - & - & - \\
\hline 311-U1326D- & & & & & & & & & & & & & & & & & & & \\
\hline $2 \mathrm{X}-2,128-150$ & 91.3 & 23.0 & 8.10 & 6.3 & 32.0 & 564.9 & 0.2 & 4.5 & 2.5 & 238.2 & 421.0 & 5.2 & 33.5 & 8.3 & 4.0 & 89.9 & 3.4 & 274.3 & 15.6 \\
\hline $2 X-5,104-144$ & 95.6 & 30.0 & 7.94 & 9.0 & 32.2 & 569.9 & 0.2 & 6.2 & 2.7 & 248.0 & 416.1 & 5.5 & 32.4 & 8.4 & 3.9 & 91.5 & 3.0 & 279.1 & 16.0 \\
\hline $3 X-4,61-90$ & 103.4 & 4.5 & - & - & 32.2 & 570.7 & 0.7 & - & 4.7 & 146.3 & 412.8 & 6.9 & 33.9 & 6.1 & 5.5 & 77.3 & 5.9 & 184.5 & 18.2 \\
\hline $3 X-4,90-119$ & 103.6 & 2.0 & - & - & 21.0 & 367.6 & 1.2 & - & 2.9 & - & - & - & - & - & - & - & - & - & - \\
\hline $3 X-4,90-119$ & 103.6 & 17.0 & - & - & 32.1 & 567.9 & 0.0 & 6.2 & 4.0 & 196.4 & 418.1 & 6.4 & 36.7 & 5.6 & 6.5 & 80.8 & 6.1 & 226.4 & 18.9 \\
\hline $4 X-3,40-106$ & 111.4 & 29.0 & 8.23 & 11.8 & 32.0 & 554.1 & 5.3 & 7.0 & 4.0 & 273.4 & 413.1 & 6.1 & 37.3 & 5.2 & 7.2 & 79.0 & 4.2 & 245.7 & 17.6 \\
\hline $4 X-5,126-146$ & 114.5 & 14.0 & - & - & 21.7 & 352.3 & 3.1 & 4.5 & 3.0 & 186.2 & 280.3 & 3.8 & 23.2 & 3.4 & 6.8 & 47.0 & 0.0 & 146.7 & 10.3 \\
\hline $5 X-3,102-150$ & 121.3 & 9.0 & - & - & 33.2 & 570.6 & 1.7 & 9.5 & 5.8 & 318.7 & 453.3 & 7.5 & 37.6 & 5.1 & 7.4 & 80.2 & 2.6 & 230.9 & 18.7 \\
\hline $5 X-4,115-150$ & 122.9 & 17.0 & 7.97 & 16.7 & 33.7 & 574.3 & 0.8 & 9.5 & 5.8 & 316.8 & 396.8 & 6.3 & 32.4 & 4.9 & 6.5 & 80.5 & 3.8 & 243.9 & 17.8 \\
\hline $6 X-3,100-113$ & 131.1 & 8.0 & - & - & 17.0 & 307.7 & 0.4 & 7.0 & 3.3 & 241.3 & 227.8 & 3.1 & 17.8 & 3.4 & 5.3 & 41.5 & 0.0 & 144.3 & 9.3 \\
\hline $6 X-4,90-132$ & 132.2 & 23.0 & 8.14 & 17.2 & 32.0 & 564.9 & 0.2 & 12.0 & 6.7 & 452.6 & 429.8 & 7.1 & 34.4 & 5.7 & 6.1 & 80.0 & 3.1 & 248.0 & 18.7 \\
\hline $7 X-1,73-96$ & 137.4 & 5.0 & - & - & 26.2 & 442.2 & 3.5 & 9.5 & 5.2 & - & - & - & - & - & - & - & - & - & - \\
\hline $7 X-3,0-50$ & 139.0 & 28.0 & 8.04 & 16.1 & 33.5 & 572.7 & 1.7 & 10.3 & 6.8 & 443.5 & 428.6 & 7.1 & 34.6 & 6.4 & 5.4 & 85.6 & 6.6 & 267.4 & 21.1 \\
\hline $8 X-2,36-86$ & 148.4 & 25.0 & - & - & 33.7 & 576.9 & 0.9 & 9.5 & 7.6 & 569.1 & 433.8 & 7.0 & 33.9 & 7.6 & 4.5 & 87.3 & 22.8 & 243.9 & 28.1 \\
\hline $8 X-2,86-96$ & 148.7 & 3.0 & - & - & 25.2 & 405.5 & 5.3 & - & 5.8 & - & - & - & - & - & - & - & - & - & - \\
\hline $9 X-1,84-134$ & 157.0 & 31.0 & - & - & 33.5 & 576.6 & 2.9 & 11.2 & 7.3 & 796.2 & 438.5 & 6.9 & 32.9 & 8.2 & 4.0 & 84.1 & 25.7 & 283.0 & 26.8 \\
\hline
\end{tabular}


Table T3 (continued).

\begin{tabular}{|c|c|c|c|c|c|c|c|c|c|c|c|c|c|c|c|c|c|c|c|}
\hline \multirow{2}{*}{$\begin{array}{l}\text { Core, section, } \\
\text { interval (cm) }\end{array}$} & \multirow{2}{*}{$\begin{array}{l}\text { Depth } \\
\text { (mbsf) }\end{array}$} & \multirow{2}{*}{$\begin{array}{l}\text { Volume } \\
(\mathrm{mL})\end{array}$} & \multirow[b]{2}{*}{$\mathrm{pH}$} & \multirow{2}{*}{$\begin{array}{c}\text { Alkalinity } \\
(\mathrm{mM})\end{array}$} & \multirow[b]{2}{*}{ Salinity } & \multirow{2}{*}{$\underset{(\mathrm{mM})}{\mathrm{Cl}}$} & \multirow{2}{*}{$\begin{array}{l}\mathrm{SO}_{4} \\
(\mathrm{mM})\end{array}$} & \multirow{2}{*}{$\begin{array}{l}\mathrm{PO}_{4} \\
(\mu \mathrm{M})\end{array}$} & \multirow{2}{*}{$\begin{array}{l}\mathrm{NH}_{4} \\
(\mathrm{mM})\end{array}$} & \multirow{2}{*}{$\begin{array}{c}\mathrm{H}_{4} \mathrm{SiO}_{4} \\
(\mu \mathrm{M})\end{array}$} & \multicolumn{4}{|c|}{ Cations (mM) } & \multirow[b]{2}{*}{$\mathrm{Mg} / \mathrm{Ca}$} & \multicolumn{4}{|c|}{ Trace elements $(\mu \mathrm{M})$} \\
\hline & & & & & & & & & & & $\mathrm{Na}$ & $\mathrm{K}$ & $\mathrm{Mg}$ & $\mathrm{Ca}$ & & $\mathrm{Sr}$ & $\mathrm{Li}$ & B & $\mathrm{Ba}$ \\
\hline $9 X-4,35-48$ & 158.5 & 2.0 & - & - & 20.0 & 458.8 & 1.7 & - & 5.1 & 412.9 & 331.7 & 5.5 & 21.7 & 5.4 & 4.0 & 60.2 & 19.5 & 155.1 & 20.4 \\
\hline $9 \times-4,35-48$ & 158.5 & 12.0 & 8.21 & 11.3 & 27.0 & 320.6 & 2.9 & 3.7 & 6.8 & - & - & - & - & - & - & - & - & - & - \\
\hline $10 X-2,97-142$ & 168.3 & 37.0 & 7.79 & 14.5 & 33.8 & 582.1 & 0.4 & 7.0 & 7.4 & 755.6 & 426.1 & 6.3 & 30.5 & 8.1 & 3.8 & 91.7 & 25.2 & 249.4 & 19.4 \\
\hline $10 X-6,0-66$ & 172.4 & 34.0 & 8.05 & 11.9 & 33.8 & 516.4 & 0.0 & 3.7 & 7.7 & 498.1 & 432.2 & 6.8 & 28.6 & 8.2 & 3.5 & 92.8 & 23.9 & 187.4 & 21.3 \\
\hline $10 X-6,0-66$ & 172.4 & 12.5 & - & - & 30.0 & 581.3 & 0.7 & - & 7.8 & 284.4 & 235.0 & 3.9 & 15.7 & 4.2 & 3.7 & 76.4 & 22.4 & 159.8 & 20.9 \\
\hline $11 X-1,38-49$ & 175.6 & 2.5 & - & - & 27.5 & 457.2 & 3.9 & 2.6 & 6.4 & - & - & - & - & - & - & - & - & - & - \\
\hline $11 X-1,38-49$ & 175.6 & 15.0 & - & - & 27.5 & 454.8 & 4.7 & 2.6 & 6.4 & 387.1 & 344.8 & 5.6 & 25.2 & 6.4 & 3.9 & 71.7 & 22.4 & 185.8 & 11.0 \\
\hline $11 X-4,100-150$ & 179.9 & 18.5 & - & - & 33.8 & 580.3 & 0.6 & 5.1 & 7.4 & 696.1 & 417.9 & 6.1 & 28.8 & 8.2 & 3.5 & 95.8 & 22.9 & 246.3 & 25.4 \\
\hline $12 X-1,75-125$ & 185.8 & 25.0 & 7.85 & 12.1 & 33.5 & 579.7 & 0.2 & 6.8 & 7.1 & 731.9 & 404.2 & 5.6 & 29.4 & 7.9 & 3.7 & 97.1 & 18.7 & 245.1 & 24.3 \\
\hline $12 X-3,100-150$ & 188.8 & 15.0 & - & - & 32.0 & 538.4 & 2.6 & 2.6 & 6.8 & 377.3 & 389.5 & 6.0 & 29.7 & 7.4 & 4.0 & 92.0 & 27.4 & 204.2 & 23.4 \\
\hline $12 X-3,100-150$ & 188.8 & 42.0 & 7.97 & 11.1 & 32.5 & 560.0 & 0.6 & 3.4 & 7.3 & 574.6 & 386.5 & 6.0 & 24.8 & 7.4 & 3.4 & 95.1 & 18.8 & 233.6 & 25.2 \\
\hline $13 X-1,100-110$ & 195.5 & 9.0 & - & - & 31.8 & 555.5 & 1.0 & 3.4 & 6.2 & 569.5 & 409.7 & 6.1 & 29.8 & 7.5 & 4.0 & 90.4 & 14.2 & 223.7 & 23.8 \\
\hline $13 X-1,100-110$ & 195.5 & 2.0 & - & - & 31.8 & 535.2 & 8.3 & - & 6.9 & - & - & - & - & - & - & - & - & - & - \\
\hline $13 X-4,60-112$ & 198.9 & 46.0 & 8.07 & 9.3 & 32.5 & 575.8 & 1.7 & 1.8 & 7.0 & 318.2 & 479.1 & 7.8 & 22.2 & 7.2 & 3.1 & 94.7 & 24.0 & 213.6 & 20.6 \\
\hline $14 X-3,58-73$ & 206.9 & 3.5 & - & - & 29.5 & 517.9 & 1.9 & - & 5.9 & - & - & - & - & - & - & - & - & - & - \\
\hline $14 X-3,58-73$ & 206.9 & 18.0 & - & - & 32.0 & 530.3 & 2.1 & 1.8 & 6.2 & 426.8 & 379.3 & 5.3 & 28.1 & 6.7 & 4.2 & 88.9 & 16.6 & 234.8 & 20.3 \\
\hline $14 X-5,0-50$ & 208.8 & 16.0 & - & - & 33.8 & 586.3 & 5.9 & 3.4 & 6.6 & 631.3 & 431.2 & 5.8 & 30.5 & 7.9 & 3.9 & 99.7 & 13.0 & 208.1 & 23.3 \\
\hline $15 X-3,100-150$ & 217.6 & 22.5 & 8.06 & 9.4 & 33.0 & 580.2 & 0.0 & 2.6 & 7.0 & 395.9 & 416.4 & 5.8 & 30.8 & 7.8 & 4.0 & 98.6 & 8.0 & 231.7 & 23.9 \\
\hline $15 X-5,50-100$ & 220.1 & 23.0 & - & - & 32.8 & 570.8 & 0.5 & 2.6 & 6.6 & 426.1 & 434.9 & 5.7 & 30.4 & 7.7 & 4.0 & 105.5 & 8.3 & 219.3 & 21.5 \\
\hline $16 X-3,0-50$ & 226.6 & 8.0 & - & - & 33.0 & 579.7 & 0.0 & 2.6 & 6.9 & 258.7 & 425.2 & 6.3 & 30.8 & 7.8 & 4.0 & 104.4 & 9.1 & 180.3 & 27.7 \\
\hline $16 X-5,0-52$ & 229.2 & 26.0 & 7.95 & 9.1 & 33.7 & 578.4 & 0.4 & 2.6 & 7.0 & 264.7 & 27.5 & 1.0 & - & - & - & 106.8 & 10.6 & 207.9 & 28.5 \\
\hline $17 X-3,0-100$ & 236.4 & 21.0 & - & - & 33.7 & 580.7 & 0.0 & 2.6 & 7.1 & 306.9 & 417.8 & 6.0 & 29.3 & 8.6 & 3.4 & 110.2 & 16.7 & 219.7 & 31.7 \\
\hline $18 X-3,0-90$ & 245.1 & 1.5 & 7.85 & 9.3 & 15.5 & 218.2 & 4.7 & 1.8 & 7.0 & 436.8 & 419.3 & 6.1 & 27.2 & 9.6 & 2.8 & 110.4 & 30.1 & 246.1 & 36.8 \\
\hline $18 X-3,109-120$ & 245.8 & 22.0 & - & - & 33.7 & 582.2 & 0.0 & - & 3.8 & - & - & - & - & - & - & - & - & - & - \\
\hline $19 X-2,0-83$ & 254.0 & 4.0 & - & - & 23.0 & 365.6 & 6.3 & - & 4.6 & - & - & - & - & - & - & - & - & - & - \\
\hline $19 X-2,0-83$ & 254.0 & 24.0 & 7.82 & 9.9 & 33.5 & 578.7 & 0.0 & 3.4 & 7.2 & 639.5 & 473.0 & 6.8 & 31.7 & 11.4 & 2.8 & 111.3 & 36.2 & 245.5 & 40.1 \\
\hline $20 X-2,33-45$ & 263.7 & 15.0 & - & - & 32.0 & 556.4 & 1.4 & - & 6.6 & - & - & - & - & - & - & - & - & - & - \\
\hline $20 X-4,50-150$ & 266.0 & 22.0 & - & - & 33.5 & 583.6 & 0.0 & 1.8 & 6.6 & 409.3 & 408.3 & 5.6 & 27.0 & 10.7 & 2.5 & 111.4 & 33.4 & 195.4 & 49.5 \\
\hline $20 X-6,0-100$ & 268.5 & 30.0 & - & - & 33.3 & 584.6 & 0.0 & 1.8 & 7.0 & 201.1 & 401.4 & 6.1 & 25.2 & 10.1 & 2.5 & 113.0 & 34.3 & 162.3 & 43.4 \\
\hline
\end{tabular}

Notes: ${ }^{*}=$ no interstitial water squeezed because of poor quality of sample. $-=$ no data. 
Table T4. Concentrations of solutes corrected for drill-fluid contamination in interstitial waters, Site U1326. (See table notes. Continued on next page.)

\begin{tabular}{|c|c|c|c|c|c|c|c|c|c|c|c|c|c|c|c|c|c|c|c|}
\hline \multirow{2}{*}{$\begin{array}{l}\text { Core, section, } \\
\text { interval }(\mathrm{cm})\end{array}$} & \multirow{2}{*}{$\begin{array}{l}\text { Depth } \\
\text { (mbsf) }\end{array}$} & \multirow{2}{*}{$\begin{array}{l}\text { Volume } \\
(\mathrm{mL})\end{array}$} & \multirow[b]{2}{*}{$\mathrm{pH}$} & \multirow{2}{*}{$\begin{array}{c}\text { Alkalinity } \\
(\mathrm{mM})\end{array}$} & \multirow[b]{2}{*}{ Salinity } & \multirow{2}{*}{$\underset{(\mathrm{mM})}{\mathrm{Cl}}$} & \multirow{2}{*}{$\begin{array}{c}\mathrm{SO}_{4} \\
(\mathrm{mM})\end{array}$} & \multirow{2}{*}{$\begin{array}{l}\mathrm{PO}_{4} \\
(\mu \mathrm{M})\end{array}$} & \multirow{2}{*}{$\begin{array}{l}\mathrm{NH}_{4} \\
(\mathrm{mM})\end{array}$} & \multirow{2}{*}{$\begin{array}{c}\mathrm{H}_{4} \mathrm{SiO}_{4} \\
(\mu \mathrm{M})\end{array}$} & \multicolumn{4}{|c|}{ Cations (mM) } & \multirow[b]{2}{*}{$\mathrm{Mg} / \mathrm{Ca}$} & \multicolumn{4}{|c|}{ Trace elements $(\mu \mathrm{M})$} \\
\hline & & & & & & & & & & & $\mathrm{Na}$ & $\mathrm{K}$ & $\mathrm{Mg}$ & $\mathrm{Ca}$ & & $\mathrm{Sr}$ & $\mathrm{Li}$ & B & $\mathrm{Ba}$ \\
\hline 311-U1326C- & & & & & & & & & & & & & & & & & & & \\
\hline $1 \mathrm{H}-1,65-80$ & 0.7 & 60 & 7.98 & 6.0 & 33.8 & 559.0 & 21.4 & 7.2 & 0.3 & 385.3 & 436.8 & 11.1 & 46.8 & 8.4 & 5.6 & 77.9 & 14.8 & 567.1 & 0.0 \\
\hline $1 \mathrm{H}-1,135-150$ & 1.4 & 62 & 8.19 & 13.1 & 33.8 & 562.5 & 13.1 & 23.0 & 0.4 & 531.2 & 428.9 & 11.0 & 46.6 & 5.9 & 7.9 & 61.1 & 12.4 & 492.0 & 0.0 \\
\hline $1 \mathrm{H}-2,65-80$ & 2.2 & 53 & 8.19 & 19.8 & 32.5 & 567.4 & 3.4 & 29.7 & 0.5 & 693.6 & 444.5 & 10.8 & 43.1 & 4.5 & 9.6 & 56.6 & 9.1 & 376.3 & 0.3 \\
\hline $1 \mathrm{H}-2,135-150$ & 2.9 & 67 & 8.11 & 23.1 & 32.5 & 566.9 & 0.0 & 34.7 & 0.7 & 751.5 & 428.4 & 10.1 & 40.0 & 4.4 & 9.0 & 71.3 & 7.3 & 511.1 & 6.7 \\
\hline $1 \mathrm{H}-3,60-72$ & 3.7 & 44 & 8.21 & 19.2 & 32.2 & 566.4 & 0.0 & 57.2 & 0.9 & 748.8 & 425.3 & 10.3 & 38.0 & 3.5 & 10.9 & 50.4 & 5.4 & 294.4 & 11.1 \\
\hline $2 \mathrm{H}-1,60-75$ & 4.6 & 36 & 8.17 & 14.9 & 32.5 & 566.4 & 7.6 & 38.8 & 0.5 & 709.6 & 423.8 & 10.2 & 39.8 & 4.9 & 8.1 & 73.7 & 8.8 & 499.3 & 3.7 \\
\hline $2 \mathrm{H}-1,135-150$ & 5.3 & 50 & 8.05 & 19.2 & 32.2 & 566.9 & 0.3 & 66.3 & 1.0 & 739.4 & 433.1 & 9.5 & 41.4 & 3.9 & 10.6 & 73.3 & 2.6 & 504.6 & 18.6 \\
\hline $2 \mathrm{H}-2,65-80$ & 6.1 & 54 & 8.02 & 19.1 & 32.0 & 566.9 & 0.1 & 71.3 & 1.1 & 732.6 & 415.9 & 9.3 & 42.2 & 4.0 & 10.4 & 77.0 & 1.5 & 453.8 & 20.9 \\
\hline $2 \mathrm{H}-2,135-150$ & 6.8 & 50 & 7.97 & 19.0 & 32.8 & 567.9 & 0.0 & 81.3 & 1.3 & 606.2 & 422.9 & 9.1 & 42.3 & 4.4 & 9.6 & 78.1 & 0.0 & 471.7 & 31.0 \\
\hline $2 \mathrm{H}-3,60-75$ & 7.6 & 54 & 7.97 & 18.5 & 32.5 & 564.9 & 0.0 & 71.3 & 1.5 & 628.0 & 416.5 & 8.9 & 33.7 & 4.0 & 8.4 & 75.2 & 0.7 & 444.8 & 25.3 \\
\hline $2 \mathrm{H}-3,135-150$ & 8.3 & 53 & 7.99 & 19.1 & 32.5 & 566.4 & 0.0 & 77.2 & 1.5 & 738.3 & 425.2 & 8.9 & 39.3 & 3.5 & 11.3 & 79.2 & 0.3 & 481.9 & 19.8 \\
\hline $2 \mathrm{H}-4,65-80$ & 9.1 & 58 & 8.11 & 19.5 & 32.2 & 564.9 & 0.0 & 73.0 & 1.8 & 647.7 & 388.0 & 8.9 & 37.3 & 3.7 & 10.0 & 76.0 & 0.0 & 470.1 & 29.1 \\
\hline $2 \mathrm{H}-4,135-150$ & 9.8 & 44 & 8.00 & 19.7 & 32.5 & 566.9 & 0.0 & 71.3 & 1.9 & 768.8 & 381.1 & 8.4 & 39.5 & 3.7 & 10.8 & 75.9 & 1.5 & 483.5 & 22.5 \\
\hline $2 \mathrm{H}-5,135-150$ & 11.3 & 46 & 7.98 & 18.8 & 32.5 & 564.9 & 0.0 & 40.5 & 1.9 & 649.4 & 414.3 & 9.4 & 29.3 & 4.3 & 6.8 & 79.4 & 0.4 & 466.6 & 31.7 \\
\hline $2 \mathrm{H}-6,135-150$ & 12.8 & 48 & 7.84 & 18.4 & 33.0 & 565.4 & 0.0 & 34.7 & 2.0 & 710.9 & 439.1 & 8.4 & 37.9 & 4.9 & 7.8 & 77.5 & 1.2 & 423.9 & 31.5 \\
\hline $3 \mathrm{H}-2,135-150$ & 16.3 & 44 & 7.75 & 18.6 & 33.2 & 565.9 & 0.0 & 22.2 & 2.6 & 703.5 & 404.8 & 8.2 & 40.9 & 4.9 & 8.3 & 71.9 & 2.4 & 436.7 & 34.3 \\
\hline $3 \mathrm{H}-4,135-150$ & 19.3 & 50 & 7.80 & 17.8 & 33.2 & 566.9 & 0.0 & 21.3 & 2.9 & 638.6 & 396.9 & 8.3 & 43.7 & 5.5 & 7.9 & 75.2 & 3.1 & 414.5 & 34.4 \\
\hline $4 \mathrm{H}-2,130-150$ & 25.8 & 38 & 8.03 & 19.7 & 33.2 & 566.9 & 0.0 & 14.7 & 2.9 & 271.4 & 401.0 & 7.9 & 39.5 & 5.2 & 7.6 & 83.2 & 0.0 & 395.1 & 20.6 \\
\hline $5 X-2,117-142^{*}$ & 33.2 & - & - & - & - & - & - & - & - & - & - & - & - & - & - & - & - & - & - \\
\hline $5 X-5,0-35^{*}$ & 36.2 & - & - & - & - & - & - & - & - & - & - & - & - & - & - & - & - & - & - \\
\hline $6 \mathrm{X}-2,125-150$ & 42.9 & 18 & 8.02 & 8.0 & 32.0 & 570.7 & 0.0 & 3.9 & 2.6 & 311.5 & 412.9 & 6.9 & 32.1 & 6.7 & 4.8 & 82.0 & 0.0 & 414.2 & 11.9 \\
\hline $6 X-4,83-96$ & 44.9 & 2 & - & - & 4.6 & 90.1 & 0.0 & 3.7 & 0.4 & - & - & - & - & - & - & - & - & - & - \\
\hline $6 X-4,83-96$ & 44.9 & 3 & - & - & 31.7 & 556.5 & 0.0 & 1.2 & 2.3 & - & - & - & - & - & - & - & - & - & - \\
\hline $6 X-4,83-96$ & 44.9 & 7 & - & - & 15.1 & 273.1 & 0.0 & - & 1.5 & 179.9 & 186.1 & 2.7 & 11.1 & 3.4 & 3.2 & 29.2 & 0.0 & 128.3 & 6.9 \\
\hline $7 X-1,93-133$ & 50.8 & 9 & 7.99 & 4.7 & 31.5 & 571.6 & 0.0 & 3.0 & 2.4 & 219.9 & 420.7 & 6.3 & 33.7 & 9.0 & 3.7 & 86.2 & 0.0 & 425.2 & 14.2 \\
\hline $7 X-3,74-101$ & 53.4 & 7 & - & - & 9.4 & 572.3 & 0.0 & 2.2 & 0.9 & 316.1 & 405.9 & 5.6 & 30.6 & 9.9 & 3.1 & 93.0 & 0.0 & 302.6 & 16.4 \\
\hline $7 X-3,74-101$ & 53.4 & 8.5 & - & - & 32.0 & 212.1 & 0.0 & 1.2 & 1.9 & - & - & - & - & - & - & - & - & - & - \\
\hline $9 X-2,0-25$ & 70.7 & 34 & 8.24 & 2.7 & 29.2 & 565.0 & 0.0 & 1.4 & 1.9 & 187.0 & 413.8 & 4.6 & 20.0 & 18.8 & 1.1 & 92.1 & 0.0 & 408.3 & 16.3 \\
\hline $9 X-3,66-91$ & 72.9 & 23 & 8.17 & 2.7 & 32.0 & 570.5 & 0.0 & 1.2 & 1.8 & 173.8 & 432.8 & 5.7 & 23.6 & 15.2 & 1.6 & 91.5 & 0.0 & 399.4 & 15.0 \\
\hline $10 X-2,0-30$ & 80.4 & 7 & - & - & 32.1 & 570.0 & 0.0 & 1.2 & 1.8 & 363.9 & 413.4 & 5.4 & 25.8 & 17.2 & 1.5 & 87.8 & 0.0 & 407.6 & 14.9 \\
\hline $12 \mathrm{P}-1,3-14$ & 83.8 & 16 & - & - & 11.4 & 438.9 & 0.0 & - & - & - & - & - & - & - & - & - & - & - & - \\
\hline $12 \mathrm{P}-1,14-24$ & 83.9 & 8 & - & - & 27.8 & 503.3 & 0.0 & - & - & - & - & - & - & - & - & - & - & - & - \\
\hline 311-U1326D- & & & & & & & & & & & & & & & & & & & \\
\hline $2 X-2,128-150$ & 91.3 & 23.0 & 8.10 & 6.3 & 32.0 & 564.9 & 0.0 & 4.5 & 2.5 & 238.2 & 421.0 & 5.2 & 33.5 & 8.3 & 4.0 & 89.9 & 3.4 & 274.3 & 15.6 \\
\hline $2 X-5,104-144$ & 95.6 & 30.0 & 7.94 & 9.0 & 32.2 & 570.0 & 0.0 & 6.2 & 2.7 & 248.0 & 416.1 & 5.5 & 32.4 & 8.4 & 3.9 & 91.5 & 3.0 & 279.1 & 16.0 \\
\hline $3 X-4,61-90$ & 103.4 & 4.5 & - & - & 32.1 & 571.0 & 0.0 & - & 4.8 & 146.2 & 411.1 & 6.8 & 33.3 & 6.0 & 5.5 & 77.0 & 5.4 & 177.7 & 18.6 \\
\hline $3 X-4,90-119$ & 103.6 & 2.0 & - & - & 20.4 & 359.2 & 0.0 & - & 3.1 & - & - & - & - & - & - & - & - & - & - \\
\hline $3 X-4,90-119$ & 103.6 & 17.0 & - & - & 32.1 & 567.9 & 0.0 & 6.2 & 4.0 & 196.4 & 418.1 & 6.4 & 36.7 & 5.6 & 6.5 & 80.8 & 6.1 & 226.4 & 18.9 \\
\hline $4 \mathrm{X}-3,40-106$ & 111.4 & 29.0 & 8.23 & 14.0 & 31.5 & 553.0 & 0.0 & 8.5 & 4.9 & 301.1 & 398.1 & 5.1 & 33.5 & 4.0 & 8.4 & 77.2 & 0.0 & 199.7 & 21.5 \\
\hline $4 X-5,126-146$ & 114.5 & 14.0 & - & - & 20.2 & 327.3 & 0.0 & 5.0 & 3.3 & 190.6 & 256.1 & 3.0 & 19.5 & 2.6 & 7.6 & 42.2 & 0.0 & 110.0 & 11.6 \\
\hline $5 X-3,102-150$ & 121.3 & 9.0 & - & - & 33.1 & 571.3 & 0.0 & 10.1 & 6.2 & 329.3 & 451.6 & 7.3 & 36.6 & 4.8 & 7.7 & 79.8 & 1.0 & 217.1 & 19.9 \\
\hline $5 X-4,115-150$ & 122.9 & 17.0 & 7.97 & 17.1 & 33.7 & 574.7 & 0.0 & 9.7 & 6.0 & 321.2 & 394.6 & 6.2 & 31.8 & 4.8 & 6.6 & 80.3 & 3.2 & 238.4 & 18.2 \\
\hline $6 \mathrm{X}-3,100-113$ & 131.1 & 8.0 & - & - & 16.8 & 304.2 & 0.0 & 7.1 & 3.4 & 242.6 & 224.2 & 3.0 & 17.3 & 3.3 & 5.3 & 40.9 & 0.0 & 140.0 & 9.4 \\
\hline $6 \mathrm{X}-4,90-132$ & 132.2 & 23.0 & 8.14 & 17.2 & 32.0 & 564.9 & 0.0 & 12.0 & 6.7 & 452.6 & 429.8 & 7.1 & 34.4 & 5.7 & 6.1 & 80.0 & 3.1 & 248.0 & 18.7 \\
\hline $7 X-1,73-96$ & 137.4 & 5.0 & - & - & 25.1 & 426.1 & 0.0 & 10.8 & 6.0 & - & - & - & - & - & - & - & - & - & - \\
\hline $7 X-3,0-50$ & 139.0 & 28.0 & 8.04 & 17.0 & 33.4 & 573.5 & 0.0 & 11.0 & 7.2 & 461.6 & 425.4 & 6.8 & 33.3 & 6.1 & 5.5 & 85.5 & 5.3 & 256.2 & 22.4 \\
\hline $8 X-2,36-86$ & 148.4 & 25.0 & - & - & 33.7 & 577.5 & 0.0 & 9.8 & 7.8 & 583.1 & 432.2 & 6.9 & 33.3 & 7.5 & 4.5 & 87.3 & 22.7 & 237.0 & 29.1 \\
\hline $8 X-2,86-96$ & 148.7 & 3.0 & - & - & 23.1 & 371.0 & 0.0 & - & 7.2 & - & - & - & - & - & - & - & - & - & - \\
\hline
\end{tabular}


Table T4 (continued).

\begin{tabular}{|c|c|c|c|c|c|c|c|c|c|c|c|c|c|c|c|c|c|c|c|}
\hline \multirow{2}{*}{$\begin{array}{l}\text { Core, section, } \\
\text { interval }(\mathrm{cm})\end{array}$} & \multirow{2}{*}{$\begin{array}{l}\text { Depth } \\
\text { (mbsf) }\end{array}$} & \multirow{2}{*}{$\begin{array}{l}\text { Volume } \\
\text { (mL) }\end{array}$} & \multirow[b]{2}{*}{$\mathrm{pH}$} & \multirow{2}{*}{$\begin{array}{c}\text { Alkalinity } \\
(\mathrm{mM})\end{array}$} & \multirow[b]{2}{*}{ Salinity } & \multirow{2}{*}{$\underset{(\mathrm{mM})}{\mathrm{Cl}}$} & \multirow{2}{*}{$\begin{array}{c}\mathrm{SO}_{4} \\
(\mathrm{mM})\end{array}$} & \multirow{2}{*}{$\begin{array}{l}\mathrm{PO}_{4} \\
(\mu \mathrm{M})\end{array}$} & \multirow{2}{*}{$\begin{array}{c}\mathrm{NH}_{4} \\
(\mathrm{mM})\end{array}$} & \multirow{2}{*}{$\begin{array}{c}\mathrm{H}_{4} \mathrm{SiO}_{4} \\
(\mu \mathrm{M})\end{array}$} & \multicolumn{4}{|c|}{ Cations (mM) } & \multirow[b]{2}{*}{$\mathrm{Mg} / \mathrm{Ca}$} & \multicolumn{4}{|c|}{ Trace elements $(\mu \mathrm{M})$} \\
\hline & & & & & & & & & & & $\mathrm{Na}$ & $\mathrm{K}$ & $\mathrm{Mg}$ & $\mathrm{Ca}$ & & $\mathrm{Sr}$ & $\mathrm{Li}$ & B & $\mathrm{Ba}$ \\
\hline $9 X-1,84-134$ & 157.0 & 31.0 & - & - & 33.4 & 578.5 & 0.0 & 12.4 & 8.1 & 867.4 & 433.9 & 6.5 & 30.5 & 7.9 & 3.9 & 83.8 & 25.6 & 264.6 & 29.7 \\
\hline $9 X-4,35-48$ & 158.5 & 2.0 & - & - & 19.1 & 452.4 & 0.0 & - & 5.5 & 429.6 & 322.3 & 5.2 & 19.6 & 5.1 & 3.8 & 58.4 & 19.1 & 136.4 & 21.7 \\
\hline $9 X-4,35-48$ & 158.5 & 12.0 & 8.21 & 12.3 & 26.2 & 294.1 & 0.0 & 4.0 & 7.5 & - & - & - & - & - & - & - & - & - & - \\
\hline $10 X-2,97-142$ & 168.3 & 37.0 & 7.79 & 14.7 & 33.8 & 582.4 & 0.0 & 7.1 & 7.5 & 763.7 & 425.3 & 6.2 & 30.2 & 8.0 & 3.8 & 91.8 & 25.2 & 246.7 & 19.7 \\
\hline $10 X-6,0-66$ & 172.4 & 34.0 & 8.05 & 11.9 & 33.8 & 516.4 & 0.0 & 3.7 & 7.7 & 498.1 & 432.2 & 6.8 & 28.6 & 8.2 & 3.5 & 92.8 & 23.9 & 187.4 & 21.3 \\
\hline $10 X-6,0-66$ & 172.4 & 12.5 & - & - & 29.9 & 581.8 & 0.0 & - & 8.0 & 287.6 & 229.3 & 3.8 & 14.8 & 4.1 & 3.6 & 76.2 & 22.2 & 153.0 & 21.4 \\
\hline $11 X-1,38-49$ & 175.6 & 2.5 & - & - & 26.4 & 441.5 & 0.0 & 2.9 & 7.4 & - & - & - & - & - & - & - & - & - & - \\
\hline $11 X-1,38-49$ & 175.6 & 15.0 & - & - & 26.2 & 434.5 & 0.0 & 3.0 & 7.7 & 433.2 & 318.5 & 4.7 & 19.6 & 5.6 & 3.5 & 68.7 & 21.5 & 134.4 & 13.2 \\
\hline $11 X-4,100-150$ & 179.9 & 18.5 & - & - & 33.8 & 580.8 & 0.0 & 5.2 & 7.5 & 708.1 & 416.5 & 6.0 & 28.2 & 8.2 & 3.5 & 96.0 & 22.8 & 241.8 & 26.0 \\
\hline $12 X-1,75-125$ & 185.8 & 25.0 & 7.85 & 12.1 & 33.5 & 579.8 & 0.0 & 6.8 & 7.1 & 731.9 & 404.2 & 5.6 & 29.4 & 7.9 & 3.7 & 97.1 & 18.7 & 245.1 & 24.3 \\
\hline $12 X-3,100-150$ & 188.8 & 15.0 & - & - & 31.8 & 536.3 & 0.0 & 2.8 & 7.5 & 400.0 & 380.4 & 5.6 & 27.3 & 7.0 & 3.9 & 92.5 & 27.5 & 179.7 & 25.7 \\
\hline $12 X-3,100-150$ & 188.8 & 42.0 & 7.97 & 11.3 & 32.5 & 560.0 & 0.0 & 3.5 & 7.5 & 583.8 & 384.5 & 5.9 & 24.2 & 7.3 & 3.3 & 95.3 & 18.6 & 228.9 & 25.7 \\
\hline $13 X-1,100-110$ & 195.5 & 9.0 & - & - & 31.7 & 555.4 & 0.0 & 3.5 & 6.4 & 584.2 & 407.3 & 5.9 & 29.0 & 7.4 & 3.9 & 90.5 & 13.8 & 215.8 & 24.7 \\
\hline $13 X-1,100-110$ & 195.5 & 2.0 & - & - & 30.8 & 525.7 & 0.0 & - & 9.6 & - & - & - & - & - & - & - & - & - & - \\
\hline $13 X-4,60-112$ & 198.9 & 46.0 & 8.07 & 9.8 & 32.4 & 576.9 & 0.0 & 1.8 & 7.4 & 328.9 & 479.0 & 7.7 & 20.1 & 7.0 & 2.9 & 95.2 & 23.8 & 198.7 & 21.9 \\
\hline $14 X-3,58-73$ & 206.9 & 3.5 & - & - & 29.2 & 515.0 & 0.0 & - & 6.3 & - & - & - & - & - & - & - & - & - & - \\
\hline $14 X-3,58-73$ & 206.9 & 18.0 & - & - & 31.8 & 528.1 & 0.0 & 1.9 & 6.7 & 448.2 & 371.5 & 4.9 & 26.1 & 6.4 & 4.1 & 89.0 & 15.8 & 218.2 & 21.8 \\
\hline $14 \mathrm{X}-5,0-50$ & 208.8 & 16.0 & - & - & 33.7 & 593.3 & 0.0 & 4.2 & 8.3 & 755.0 & 418.6 & 4.7 & 24.4 & 7.2 & 3.4 & 103.0 & 9.4 & 145.9 & 29.2 \\
\hline $15 X-3,100-150$ & 217.6 & 22.5 & 8.06 & 9.4 & 33.0 & 580.2 & 0.0 & 2.6 & 7.0 & 395.9 & 416.4 & 5.8 & 30.8 & 7.8 & 4.0 & 98.6 & 8.0 & 231.7 & 23.9 \\
\hline $15 X-5,50-100$ & 220.1 & 23.0 & - & - & 32.8 & 571.0 & 0.0 & 2.6 & 6.7 & 430.6 & 434.2 & 5.6 & 30.0 & 7.6 & 3.9 & 105.8 & 8.0 & 215.6 & 21.8 \\
\hline $16 X-3,0-50$ & 226.6 & 8.0 & - & - & 33.0 & 579.7 & 0.0 & 2.6 & 6.9 & 258.7 & 425.2 & 6.3 & 30.8 & 7.8 & 4.0 & 104.4 & 9.1 & 180.3 & 27.7 \\
\hline $16 X-5,0-52$ & 229.2 & 26.0 & 7.95 & 9.2 & 33.7 & 578.6 & 0.0 & 2.6 & 7.1 & 266.2 & 21.8 & 0.9 & - & - & - & 107.0 & 10.4 & 204.9 & 28.9 \\
\hline $17 X-3,0-100$ & 236.4 & 21.0 & - & - & 33.7 & 580.7 & 0.0 & 2.6 & 7.1 & 306.9 & 417.8 & 6.0 & 29.3 & 8.6 & 3.4 & 110.2 & 16.7 & 219.7 & 31.7 \\
\hline $18 X-3,0-90$ & 245.1 & 1.5 & 7.85 & 10.6 & 11.8 & 151.5 & 0.0 & 2.0 & 8.4 & 492.9 & 407.4 & 5.2 & 22.0 & 9.4 & 2.3 & 115.0 & 30.7 & 206.2 & 44.0 \\
\hline $18 X-3,109-120$ & 245.8 & 22.0 & - & - & 33.7 & 582.2 & 0.0 & - & 3.8 & - & - & - & - & - & - & - & - & - & - \\
\hline $19 X-2,0-83$ & 254.0 & 4.0 & - & - & 19.8 & 311.2 & 0.0 & - & 5.9 & - & - & - & - & - & - & - & - & - & - \\
\hline $19 X-2,0-83$ & 254.0 & 24.0 & 7.82 & 9.9 & 33.5 & 578.7 & 0.0 & 3.4 & 7.2 & 639.5 & 473.0 & 6.8 & 31.7 & 11.4 & 2.8 & 111.3 & 36.2 & 245.5 & 40.1 \\
\hline $20 \times-2,33-45$ & 263.7 & 15.0 & - & - & 31.9 & 556.3 & 0.0 & - & 7.0 & - & - & - & - & - & - & - & - & - & - \\
\hline $20 X-4,50-150$ & 266.0 & 22.0 & - & - & 33.5 & 583.6 & 0.0 & 1.8 & 6.6 & 409.3 & 408.3 & 5.6 & 27.0 & 10.7 & 2.5 & 111.4 & 33.4 & 195.4 & 49.5 \\
\hline $20 X-6,0-100$ & 268.5 & 30.0 & - & - & 33.3 & 584.6 & 0.0 & 1.8 & 7.0 & 201.1 & 401.4 & 6.1 & 25.2 & 10.1 & 2.5 & 113.0 & 34.3 & 162.3 & 43.4 \\
\hline
\end{tabular}

Notes: Corrections based on dissolved sulfate concentrations assuming zero sulfate concentration below the sulfate/methane interface, which at this site occurs in the uppermost $\sim 2.5 \mathrm{~m} .{ }^{*}=$ no interstitial water squeezed because of poor quality of sample. $-=$ no data. 
Table T5. Headspace gas concentrations of hydrocarbons, Holes U1326C and U1326D. (See table note. Continued on next page.)

\begin{tabular}{|c|c|c|c|c|c|c|c|}
\hline $\begin{array}{l}\text { Core, section, } \\
\text { interval }(\mathrm{cm})\end{array}$ & $\begin{array}{l}\text { Depth } \\
\text { (mbsf) }\end{array}$ & $\mathrm{C}_{1} / \mathrm{C}_{2}$ & $\begin{array}{c}\mathrm{C}_{1} \\
\text { (ppmv) }\end{array}$ & $\begin{array}{c}\mathrm{C}_{2} \\
(\mathrm{ppm} v)\end{array}$ & $\begin{array}{c}\mathrm{C}_{2=} \\
(\mathrm{ppm})\end{array}$ & $\begin{array}{c}\mathrm{C}_{3} \\
\text { (ppmv) }\end{array}$ & $\begin{array}{c}\mathrm{C}_{1} \\
(\mathrm{mM})^{*}\end{array}$ \\
\hline \multicolumn{8}{|l|}{ 311-U1326C- } \\
\hline $1 \mathrm{H}-1,80-85$ & 0.80 & & 37 & 0 & 0 & 0 & 0.02 \\
\hline $1 \mathrm{H}-2,0-5$ & 1.50 & & 25 & 0 & 0 & 0 & 0.01 \\
\hline $1 \mathrm{H}-2,80-85$ & 2.30 & 213 & 149 & 0.7 & 0 & 0 & 0.08 \\
\hline $1 \mathrm{H}-3,0-5$ & 3.00 & & 3,943 & 0 & 0 & 0 & 2.10 \\
\hline $2 \mathrm{H}-1,75-80$ & 4.65 & & 13,275 & 0 & 0 & 0 & 7.10 \\
\hline $2 \mathrm{H}-2,0-5$ & 5.40 & & 14,783 & 0 & 0 & 0 & 8.00 \\
\hline $2 \mathrm{H}-2,80-85$ & 6.20 & & 16,892 & 0 & 0 & 0 & 9.10 \\
\hline $2 \mathrm{H}-3,0-5$ & 6.90 & 17,964 & 14,371 & 0.8 & 0 & 0 & 7.80 \\
\hline $2 \mathrm{H}-3,75-80$ & 7.65 & & 9,988 & 0 & 0 & 0 & 5.40 \\
\hline $2 \mathrm{H}-4,0-5$ & 8.40 & 19,431 & 11,659 & 0.6 & 0 & 0 & 6.30 \\
\hline $2 \mathrm{H}-4,80-85$ & 9.20 & 15,108 & 10,576 & 0.7 & 0 & 0 & 5.70 \\
\hline $2 \mathrm{H}-5,0-5$ & 9.90 & & 13,612 & 0 & 0 & 0 & 7.40 \\
\hline $2 \mathrm{H}-6,0-5$ & 11.40 & 8,169 & 4,902 & 0.6 & 0 & 0 & 2.70 \\
\hline $2 \mathrm{H}-7,0-5$ & 12.90 & & 4,429 & 0 & 0 & 0 & 2.40 \\
\hline $3 \mathrm{H}-3,0-5$ & 16.40 & & 5,165 & 0 & 0.4 & 0 & 2.80 \\
\hline $3 \mathrm{H}-5,0-5$ & 19.40 & & 4,437 & 0 & 0.4 & 0 & 2.40 \\
\hline $4 \mathrm{H}-3,0-5$ & 25.90 & 8,136 & 8,136 & 1 & 0 & 0 & 4.50 \\
\hline $5 X-3,0-5$ & 33.32 & & 5,197 & 0 & 0 & 0 & 2.90 \\
\hline $5 X-4,135-140$ & 36.00 & & 3,570 & 0 & 0 & 0 & 2.00 \\
\hline $6 X-3,0-5$ & 43.00 & 17,143 & 6,858 & 0.4 & 0 & 0 & 4.00 \\
\hline $6 X-4,78-83$ & 44.80 & & 7,112 & 0 & 0 & 0 & 4.10 \\
\hline $6 X-4,92-93$ & 44.94 & & 3,206 & 0 & 0 & 0 & 1.90 \\
\hline $7 X-2,0-5$ & 51.03 & 15,457 & 7,729 & 0.5 & 0 & 0 & 4.10 \\
\hline $7 X-3,69-74$ & 53.22 & & 5,190 & 0 & 0 & 0 & 2.80 \\
\hline $7 X-3,77-78$ & 53.30 & 15,347 & 12,278 & 0.8 & 0 & 0 & 6.60 \\
\hline $7 X-3,85-86$ & 53.38 & & 3,245 & 0 & 0 & 0 & 1.70 \\
\hline $8 X-1,90-95$ & 60.30 & & 8,290 & 0 & 0 & 0 & 4.50 \\
\hline $9 \times-2,25-30$ & 70.85 & 9,608 & 5,765 & 0.6 & 0 & 0 & 3.20 \\
\hline $9 X-3,61-66$ & 72.71 & & 7,932 & 0 & 0 & 0 & 4.40 \\
\hline $10 X-1,145-150$ & 80.15 & & 3,293 & 0 & 0 & 0 & 1.80 \\
\hline \multicolumn{8}{|l|}{ 311-U1326D- } \\
\hline $2 X-3,0-5$ & 91.40 & & 3,086 & 0 & 0 & 0 & 1.70 \\
\hline $2 X-6,0-5$ & 95.84 & & 3,494 & 0 & 0 & 0 & 2.00 \\
\hline $3 X-3,0-5$ & 101.10 & & 2,891 & 0 & 0 & 0 & 1.70 \\
\hline $3 X-5,0-5$ & 103.79 & & 3,443 & 0 & 0 & 0 & 2.00 \\
\hline $4 X-3,35-40$ & 111.05 & & 2,723 & 0 & 0 & 0 & 1.60 \\
\hline $4 X-6,8-13$ & 114.65 & & 2,989 & 0 & 0 & 0 & 1.70 \\
\hline $5 X-4,0-5$ & 121.54 & & 3,147 & 0 & 0 & 0 & 1.80 \\
\hline $5 X-6,0-5$ & 123.60 & & 9,163 & 0 & 0 & 0 & 5.40 \\
\hline $6 X-4,85-90$ & 131.98 & & 3,161 & 0 & 0 & 0 & 1.90 \\
\hline $6 X-6,0-5$ & 133.45 & & 2,540 & 0 & 0 & 0 & 1.50 \\
\hline $7 X-1,68-73$ & 137.28 & & 3,037 & 0 & 0 & 0 & 1.80 \\
\hline $7 X-4,0-5$ & 140.19 & & 7,553 & 0 & 0 & 0 & 4.60 \\
\hline $8 X-2,31-36$ & 148.11 & & 1,842 & 0 & 0 & 0 & 1.10 \\
\hline $8 X-3,0-5$ & 148.76 & & 4,060 & 0 & 0 & 0 & 2.50 \\
\hline $9 X-1,79-84$ & 156.69 & & 3,725 & 0 & 0 & 0 & 2.30 \\
\hline $9 X-4,40-45$ & 158.51 & & 4,388 & 0 & 0 & 0 & 2.70 \\
\hline $9 X-5,0-5$ & 158.59 & & 5,549 & 0 & 0 & 0 & 3.40 \\
\hline $10 X-2,92-97$ & 168.02 & 7,222 & 9,389 & 1.3 & 0 & 0 & 5.90 \\
\hline $10 X-6,0-5$ & 172.02 & & 3,421 & 0 & 0 & 0 & 2.20 \\
\hline $11 X-1,41-46$ & 175.61 & 5,813 & 8,138 & 1.4 & 0 & 0 & 5.20 \\
\hline $12 X-1,70-75$ & 185.50 & & 3,448 & 0 & 0 & 0 & 2.20 \\
\hline $12 X-4,0-5$ & 189.05 & & 2,922 & 0 & 0 & 0 & 1.90 \\
\hline $13 X-1,95-100$ & 195.35 & 5,452 & 4,362 & 0.8 & 0 & 0 & 2.90 \\
\hline $13 X-1,103-106$ & 195.43 & & 2,078 & 0 & 0 & 0 & 1.40 \\
\hline $13 X-4,55-60$ & 198.55 & & 2,906 & 0 & 0 & 0 & 1.90 \\
\hline $14 X-3,65-67$ & 206.92 & & 5,311 & 0 & 0 & 0 & 3.60 \\
\hline $14 X-4,0-5$ & 207.00 & & 6,237 & 0 & 0 & 0 & 4.20 \\
\hline $14 X-5,50-55$ & 209.00 & 7,263 & 4,358 & 0.6 & 0 & 0 & 2.90 \\
\hline $15 X-3,95-100$ & 217.31 & & 3,785 & 0 & 0 & 3.3 & 2.60 \\
\hline $15 X-6,0-5$ & 220.36 & & 3,634 & 0 & 0 & 3.8 & 2.50 \\
\hline $16 X-3,50-55$ & 226.80 & & 4,148 & 0 & 0 & 0 & 2.90 \\
\hline $16 X-5,52-57$ & 229.42 & & 3,556 & 0 & 0 & 0 & 2.50 \\
\hline $17 X-3,100-105$ & 236.90 & & 2,031 & 0 & 0 & 0 & 1.40 \\
\hline $17 X-6,0-5$ & 240.34 & & 3,666 & 0 & 0 & 0 & 2.60 \\
\hline $18 \mathrm{X}-1,79-84$ & 243.39 & 3,595 & 5,752 & 1.6 & 0 & 0 & 4.10 \\
\hline
\end{tabular}


Table T5 (continued).

\begin{tabular}{cccccccc}
\hline $\begin{array}{c}\text { Core, section, } \\
\text { interval }(\mathrm{cm})\end{array}$ & $\begin{array}{c}\text { Depth } \\
(\mathrm{mbsf})\end{array}$ & $\mathrm{C}_{1} / \mathrm{C}_{2}$ & $\begin{array}{c}\mathrm{C}_{1} \\
(\text { ppmv) }\end{array}$ & $\begin{array}{c}\mathrm{C}_{2} \\
(\text { ppmv) }\end{array}$ & $\begin{array}{c}\mathrm{C}_{2=} \\
(\text { ppmv })\end{array}$ & $\begin{array}{c}\mathrm{C}_{3} \\
(\text { ppmv })\end{array}$ & $\begin{array}{c}\mathrm{C}_{1} \\
(\mathrm{mM})^{*}\end{array}$ \\
\hline $18 \mathrm{X}-2,91-96$ & 244.56 & & 2,792 & 0 & 0 & 0 & 2.00 \\
$19 \mathrm{X}-1,36-41$ & 252.56 & & 1,941 & 0 & 0 & 0 & 1.40 \\
$20 \mathrm{X}-2,28-33$ & 263.58 & 5,431 & 5,975 & 1.1 & 0 & 0 & 4.40 \\
\hline
\end{tabular}

Note: ${ }^{*}=$ dissolved residual methane obtained by the headspace equilibration method.

Table T6. Concentrations of light hydrocarbon and nonhydrocarbon gases in void gas samples, Holes U1326C and U1325D.

\begin{tabular}{|c|c|c|c|c|c|c|c|c|c|c|c|c|c|}
\hline \multirow{2}{*}{$\begin{array}{l}\text { Core, section, } \\
\text { interval }(\mathrm{cm})\end{array}$} & \multirow{2}{*}{$\begin{array}{l}\text { Depth } \\
\text { (mbsf) }\end{array}$} & \multirow[b]{2}{*}{$\mathrm{C}_{1} / \mathrm{C}_{2}$} & \multicolumn{7}{|c|}{ Hydrocarbons (ppmv) } & \multicolumn{4}{|c|}{ Volatiles (ppmv) } \\
\hline & & & $\mathrm{C}_{1}$ & $\mathrm{C}_{2}$ & $\mathrm{C}_{3}$ & $i-\mathrm{C}_{4}$ & $n-C_{4}$ & $i-C_{5}$ & $n-C_{5}$ & $\mathrm{H}_{2} \mathrm{~S}$ & $\mathrm{CO}_{2}$ & $\mathrm{O}_{2}$ & $\mathrm{~N}_{2}$ \\
\hline \multicolumn{14}{|l|}{ 311-U1326C- } \\
\hline $2 \mathrm{H}-2,65-66$ & 6.05 & 33,073 & 241,430 & 7.3 & 0 & 3.4 & 0 & 0 & 0 & 0 & 1,294 & 136,024 & 565,528 \\
\hline $2 \mathrm{H}-6,108-109$ & 12.48 & 37,803 & 805,208 & 21.3 & 0 & 19.2 & 0 & 0.1 & 0 & 0 & 2,904 & 4,309 & 139,797 \\
\hline $3 \mathrm{H}-2,78-79$ & 15.68 & 35,996 & 867,494 & 24.1 & 0 & 0.8 & 0 & 0 & 0 & 0 & 3,770 & 10,202 & 61,891 \\
\hline $3 \mathrm{H}-5,77-78$ & 20.17 & 36,302 & 885,767 & 24.4 & 0 & 0.6 & 0.2 & 0 & 2.1 & 0 & 3,274 & 3,407 & 49,660 \\
\hline $4 \mathrm{H}-1,36-37$ & 23.26 & 40,407 & 913,201 & 22.6 & 0 & 0 & 0 & 0 & 0 & 0 & 2,836 & 2,004 & 20,626 \\
\hline $4 \mathrm{H}-3,145-146$ & 27.35 & 36,398 & 815,319 & 22.4 & 0 & 0.4 & 4.1 & 0.5 & 0 & 0 & 3,787 & 56,011 & 227,538 \\
\hline $5 X-2,26-27$ & 32.16 & 43,665 & 899,497 & 20.6 & 0 & 4.4 & 0 & 0 & 0 & 0 & 1,141 & 982 & 33,417 \\
\hline $5 X-4,71-72$ & 35.36 & 42,758 & 889,364 & 20.8 & 0 & 0 & 0 & 0 & 0 & 0 & 1,161 & 831 & 43,650 \\
\hline $6 X-4,63-64$ & 44.65 & 11,132 & 916,131 & 82.3 & 0 & 0 & 0 & 0 & 0 & 0 & 0 & 1,287 & 9,936 \\
\hline $7 X-3,19-20$ & 52.72 & 17,081 & 906,995 & 53.1 & 0 & 0 & 0 & 0 & 0 & 0 & 3,590 & 3,880 & 23,269 \\
\hline $9 X-2,26-27$ & 70.86 & 15,168 & 923,747 & 60.9 & 0 & 0 & 0 & 0 & 0 & 0 & 0 & 676 & 6,975 \\
\hline $9 X-2,135-136$ & 71.95 & 20,959 & 920,096 & 43.9 & 0 & 0.2 & 0 & 0 & 0 & 0 & 0 & 868 & 10,649 \\
\hline \multicolumn{14}{|l|}{ 311-U1326D- } \\
\hline $2 X-4,66-67$ & 93.56 & 40,092 & 918,100 & 22.9 & 6.6 & 0 & 0 & 0 & 0 & 0 & 0 & 701 & 19,072 \\
\hline $2 X-5,2-3$ & 94.42 & 50,343 & 911,206 & 18.1 & 8.9 & 0 & 0 & 0 & 0 & 0 & 3,159 & 923 & 22,465 \\
\hline $3 X-2,148-149$ & 101.08 & 57,000 & 461,701 & 8.1 & 0 & 0.5 & 0 & 0 & 0 & 0 & 1,218 & 1,812 & 19,850 \\
\hline $3 X-4,35-36$ & 102.95 & 59,111 & 756,623 & 12.8 & 0 & 0.3 & 0 & 0 & 0 & 0 & 779 & 29,347 & 135,386 \\
\hline $4 X-2,1-2$ & 109.21 & 28,657 & 891,223 & 31.1 & 0 & 0.4 & 0 & 0 & 0 & 0 & 688 & 1,903 & 37,344 \\
\hline $5 X-2,1-2$ & 118.71 & 26,566 & 895,280 & 33.7 & 3.3 & 0.8 & 0 & 0 & 0 & 0 & 781 & 930 & 18,429 \\
\hline $5 X-5,8-9$ & 123.12 & 19,309 & 922,961 & 47.8 & 2.5 & 0.3 & 0 & 0 & 0 & 0 & 0 & 851 & 8,005 \\
\hline $6 \times-2,140-141$ & 129.90 & 20,391 & 917,584 & 45.0 & 3.8 & 1 & 0 & 0 & 0 & 0 & 490 & 728 & 7,541 \\
\hline $6 X-5,46-47$ & 132.91 & 26,184 & 921,689 & 35.2 & 6 & 1.7 & 0.2 & 0 & 0 & 0 & 823 & 4,596 & 23,187 \\
\hline $7 X-2,11-12$ & 137.67 & 33,684 & 902,726 & 26.8 & 12.9 & 2.5 & 0 & 0 & 0 & 0 & 2,033 & 2,114 & 21,201 \\
\hline $7 X-4,16-17$ & 140.35 & 33,523 & 921,869 & 27.5 & 8.9 & 2.1 & 0 & 0 & 0 & 0 & 977 & 612 & 7,850 \\
\hline $8 X-3,1-2$ & 148.77 & 20,643 & 918,628 & 44.5 & 10.6 & 2.8 & 0 & 0.7 & 0 & 0 & 1,450 & 700 & 10,708 \\
\hline $9 \mathrm{X}-1,24-25$ & 156.14 & 10,733 & 906,926 & 84.5 & 0 & 1.2 & 0 & 0.8 & 0 & 0 & 1,622 & 1,422 & 16,114 \\
\hline $9 X-4,4-5$ & 158.15 & 16,469 & 918,993 & 55.8 & 8.1 & 3.7 & 0 & 1.9 & 0 & 0 & 2,989 & 372 & 7,244 \\
\hline $10 X-2,72-73$ & 167.82 & 17,256 & 918,034 & 53.2 & 13 & 3.5 & 0.3 & 1.3 & 0 & 0 & 1,981 & 990 & 10,230 \\
\hline $11 X-2,140-141$ & 177.09 & 15,942 & 916,684 & 57.5 & 13.3 & 2.1 & 0 & 0.9 & 0 & 0 & 1,820 & 1,722 & 14,318 \\
\hline $11 X-4,57-58$ & 179.26 & 39,593 & 926,482 & 23.4 & 17.9 & 2.9 & 0 & 0.5 & 0 & 0 & 934 & 422 & 9,977 \\
\hline $12 X-2,40-42$ & 186.45 & 22,566 & 925,188 & 41.0 & 22.4 & 2.7 & 0.3 & 0.9 & 0 & 0 & 812 & 800 & 10,046 \\
\hline $13 X-2,144-145$ & 196.94 & 8,658 & 926,421 & 107.0 & 10.6 & 1 & 0 & 0.7 & 0 & 0 & 0 & 840 & 7,602 \\
\hline $13 X-4,62-63$ & 198.62 & 21,030 & 925,334 & 44.0 & 34.4 & 3.8 & 0.2 & 1.1 & 0 & 0 & 839 & 1,051 & 10,250 \\
\hline $14 X-1,26-27$ & 204.26 & 11,987 & 925,389 & 77.2 & 28.6 & 3.1 & 0.2 & 0.8 & 0 & 0 & 511 & 1,183 & 10,268 \\
\hline $14 X-4,137-138$ & 208.37 & 16,575 & 933,150 & 56.3 & 35.1 & 3.9 & 0 & 0.7 & 0 & 0 & 364 & 609 & 7,239 \\
\hline $15 X-1,104-105$ & 214.64 & 26,830 & 912,208 & 34.0 & 52.5 & 7.9 & 0.6 & 1.2 & 0 & 0 & 658 & 989 & 9,806 \\
\hline $15 X-3,63-64$ & 216.99 & 27,612 & 924,992 & 33.5 & 54.6 & 8.4 & 0.5 & 1.1 & 0 & 0 & 899 & 1,042 & 10,321 \\
\hline $16 X-3,27-28$ & 226.57 & 24,808 & 816,199 & 32.9 & 35.7 & 8.4 & 0.9 & 1.2 & 0 & 0 & 345 & 339 & 4,189 \\
\hline $16 X-4,93-94$ & 228.73 & 23,710 & 934,177 & 39.4 & 30.5 & 9.7 & 0.9 & 1.2 & 0 & 0 & 869 & 25,997 & 100,111 \\
\hline $17 X-3,136-137$ & 237.26 & 23,796 & 839,984 & 35.3 & 25 & 7.1 & 0.7 & 1.1 & 0 & 0 & 1,618 & 14,125 & 84,535 \\
\hline $18 X-2,88-89$ & 244.53 & 7,497 & 919,152 & 122.6 & 0 & 0.4 & 0 & 0 & 0 & 0 & 0 & 6,350 & 26,334 \\
\hline $18 X-3,85-86$ & 245.46 & 7,476 & 907,581 & 121.4 & 4.7 & 0.3 & 0 & 0.1 & 0 & 0 & 0 & 5,054 & 20,943 \\
\hline $19 X-1,10-11$ & 252.30 & 6,153 & 230,732 & 37.5 & 0 & 0.4 & 12.1 & 0 & 0 & 0 & 429 & 169,219 & 568,907 \\
\hline $20 X-4,1-2$ & 265.05 & 11,717 & 928,021 & 79.2 & 15.1 & 2 & 0.3 & 0.4 & 0 & 0 & 560 & 745 & 6,199 \\
\hline $20 X-7,1-2$ & 269.05 & 12,915 & 932,457 & 72.2 & 14.2 & 1.4 & 0.2 & 0 & 0 & 0 & 669 & 668 & 5,675 \\
\hline
\end{tabular}


Table T7. Concentrations of light hydrocarbons from dissociated gas hydrate, Hole U1326C.

\begin{tabular}{rcccccc}
\hline $\begin{array}{c}\text { Core, section, } \\
\text { interval }(\mathrm{cm})\end{array}$ & $\begin{array}{c}\text { Depth } \\
\text { (mbsf) }\end{array}$ & $\mathrm{C}_{1} / \mathrm{C}_{2}$ & $\begin{array}{c}\mathrm{C}_{1} \\
\text { (ppmv) }\end{array}$ & $\begin{array}{c}\mathrm{C}_{2} \\
\text { (ppmv) }\end{array}$ & $\begin{array}{c}\mathrm{C}_{2=} \\
(\mathrm{ppmv})\end{array}$ & $\begin{array}{c}\mathrm{C}_{3} \\
(\mathrm{ppmv})\end{array}$ \\
\hline $311-\mathrm{U} 1326 \mathrm{C}-$ & & & & & & \\
$6 \mathrm{X}-4,63-64$ & 44.87 & 10,682 & 386,710 & 36 & 0.7 & 0 \\
$7 \mathrm{X}-3,19-20$ & 53.30 & 12,167 & 843,193 & 69 & 1.6 & 0 \\
\hline
\end{tabular}

Table T8. Concentrations of inorganic carbon, $\mathrm{CaCO}_{3}$, total carbon, total organic carbon, total nitrogen, and $\mathrm{C} / \mathrm{N}$ ratios in sediment, Holes U1326C and U1326D.

\begin{tabular}{|c|c|c|c|c|c|c|c|}
\hline \multirow[b]{2}{*}{$\begin{array}{l}\text { Core, section, } \\
\text { interval, } \mathrm{cm}\end{array}$} & \multirow[b]{2}{*}{$\begin{array}{l}\text { Depth } \\
\text { (mbsf) }\end{array}$} & \multicolumn{4}{|c|}{ Carbon (wt\%) } & \multirow{2}{*}{$\begin{array}{l}\text { Total } \\
\text { nitrogen } \\
\text { (wt\%) }\end{array}$} & \multirow[b]{2}{*}{$\mathrm{C} / \mathrm{N}$} \\
\hline & & Inorganic & $\mathrm{CaCO}_{3}$ & Total & $\begin{array}{l}\text { Total } \\
\text { organic }\end{array}$ & & \\
\hline \multicolumn{8}{|l|}{ 311-U1326C- } \\
\hline $1 \mathrm{H}-1,65-80$ & 0.65 & 0.44 & 3.65 & 0.91 & 0.47 & 0.031 & 15.2 \\
\hline $1 \mathrm{H}-1,135-150$ & 1.35 & 0.59 & 4.94 & 0.78 & 0.19 & 0.017 & 11.2 \\
\hline $1 \mathrm{H}-2,65-80$ & 2.15 & 1.95 & 16.27 & 2.37 & 0.42 & 0.037 & 11.4 \\
\hline $1 \mathrm{H}-2,135-150$ & 2.85 & 0.62 & 5.18 & 1.04 & 0.42 & 0.044 & 9.5 \\
\hline $1 \mathrm{H}-3,60-72$ & 3.60 & 0.93 & 7.78 & 1.43 & 0.50 & 0.039 & 12.8 \\
\hline $2 \mathrm{H}-1,135-150$ & 5.25 & 0.32 & 2.64 & 0.81 & 0.49 & 0.034 & 14.4 \\
\hline $2 \mathrm{H}-2,65-80$ & 6.05 & 0.63 & 5.27 & 1.43 & 0.80 & 0.080 & 10.0 \\
\hline $2 \mathrm{H}-3,60-75$ & 7.50 & 1.05 & 8.72 & 1.74 & 0.69 & 0.061 & 11.3 \\
\hline $2 \mathrm{H}-3,135-150$ & 8.25 & 0.73 & 6.11 & 1.34 & 0.61 & 0.051 & 12.0 \\
\hline $2 \mathrm{H}-4,65-80$ & 9.05 & 0.38 & 3.21 & 0.80 & 0.42 & 0.040 & 10.5 \\
\hline $2 \mathrm{H}-5,135-150$ & 11.25 & 0.86 & 7.19 & 1.36 & 0.50 & 0.048 & 10.4 \\
\hline $2 \mathrm{H}-6,135-150$ & 12.75 & 0.32 & 2.66 & 0.77 & 0.45 & 0.056 & 8.0 \\
\hline $3 \mathrm{H}-2,135-150$ & 16.25 & 0.74 & 6.16 & 1.34 & 0.60 & 0.081 & 7.4 \\
\hline $3 \mathrm{H}-4,135-150$ & 19.25 & 0.70 & 5.86 & 1.30 & 0.60 & 0.056 & 10.7 \\
\hline $4 \mathrm{H}-2,130-150$ & 25.70 & 0.30 & 2.49 & 0.63 & 0.33 & 0.042 & 7.9 \\
\hline $6 X-2,125-150$ & 42.75 & 0.24 & 1.97 & 0.52 & 0.28 & 0.039 & 7.2 \\
\hline $7 X-3,74-101$ & 53.27 & 0.17 & 1.38 & 0.72 & 0.55 & 0.052 & 10.6 \\
\hline $10 X-2,0-30$ & 80.20 & 0.13 & 1.12 & 0.37 & 0.24 & 0.024 & 10.0 \\
\hline \multicolumn{8}{|l|}{ 311-U1326D- } \\
\hline $2 X-2,125-150$ & 91.15 & 0.11 & 0.96 & 0.47 & 0.36 & 0.043 & 8.3 \\
\hline $3 X-4,61-90$ & 103.21 & 0.31 & 2.62 & 0.61 & 0.30 & 0.030 & 10.1 \\
\hline $4 X-3,40-106$ & 111.10 & 0.21 & 1.73 & 0.72 & 0.51 & 0.055 & 9.2 \\
\hline $5 X-3,102-150$ & 121.06 & 0.14 & 1.17 & 0.54 & 0.40 & 0.044 & 9.0 \\
\hline $6 X-3,100-113$ & 131.00 & 0.08 & 0.64 & 0.11 & 0.03 & 0.015 & 2.1 \\
\hline $7 X-3,0-50$ & 138.74 & 0.23 & 1.95 & 0.61 & 0.38 & 0.066 & 5.8 \\
\hline $8 X-2,36-86$ & 148.16 & 0.72 & 6.02 & 1.20 & 0.48 & 0.061 & 7.9 \\
\hline $9 X-4,35-48$ & 158.46 & 0.26 & 2.17 & 0.75 & 0.49 & 0.062 & 7.9 \\
\hline $10 \times-2,97-142$ & 168.07 & 0.48 & 4.00 & 1.11 & 0.63 & 0.086 & 7.3 \\
\hline $11 X-4,100-150$ & 179.69 & 0.25 & 2.07 & 0.68 & 0.43 & 0.054 & 7.9 \\
\hline $12 X-1,75-125$ & 185.55 & 0.60 & 5.00 & 1.18 & 0.58 & 0.073 & 8.0 \\
\hline $13 X-4,60-112$ & 198.60 & 0.14 & 1.14 & 0.23 & 0.09 & 0.013 & 7.2 \\
\hline
\end{tabular}


Table T9. Perfluorocarbon tracer and fluorescent microsphere concentrations, Site U1326.

\begin{tabular}{|c|c|c|c|c|c|c|}
\hline \multirow{2}{*}{$\begin{array}{l}\text { Core, section, } \\
\text { interval }(\mathrm{cm})\end{array}$} & \multirow{2}{*}{$\begin{array}{l}\text { Depth } \\
\text { (mbsf) }\end{array}$} & \multicolumn{2}{|c|}{$\begin{array}{c}\text { Detected PFT } \\
\text { (ng/g sediment) }\end{array}$} & \multicolumn{2}{|c|}{$\begin{array}{c}\text { Detected particles } \\
\text { (number/g sediment) }\end{array}$} & \multirow[b]{2}{*}{ Comments } \\
\hline & & Inner & Outer & Inner & Outer & \\
\hline \multicolumn{7}{|l|}{ APC cores } \\
\hline \multicolumn{7}{|l|}{ 311-U1326C- } \\
\hline $1 \mathrm{H}-2,85-90$ & 2.35 & ND & ND & $>0.1 \times 10^{4}$ & $0.8 \times 10^{4}$ & Near mudline \\
\hline $1 \mathrm{H}-3,0-5$ & 3.00 & BDL & 0.0013 & BDL & $>0.1 \times 10^{4}$ & \\
\hline $4 \mathrm{H}-1,5-6$ & 22.95 & ND & ND & $>0.1 \times 10^{4}$ & $>0.1 \times 10^{4}$ & Sand layer \\
\hline $4 \mathrm{H}-2,0-5$ & 24.40 & BDL & BDL & BDL & BDL & \\
\hline $4 \mathrm{H}-3,110-111$ & 24.00 & ND & ND & BDL & $>0.1 \times 10^{4}$ & Sand layer \\
\hline \multicolumn{7}{|l|}{$\mathrm{XCB}$ cores } \\
\hline \multicolumn{7}{|l|}{ 311-U1326D- } \\
\hline $10 X-3,135-150$ & 169.87 & ND & ND & BDL & $>0.1 \times 10^{4}$ & Gas hydrate sample \\
\hline $14 X-1,103-116$ & 205.03 & ND & ND & $>0.1 \times 10^{4}$ & $>0.1 \times 10^{4}$ & Gas hydrate sample \\
\hline $20 X-5,119-120$ & 267.73 & ND & ND & BDL & $1.4 \times 10^{4}$ & Biscuit \\
\hline $20 X-5,124-125$ & 267.78 & ND & ND & $>0.1 \times 10^{4}$ & $>0.1 \times 10^{4}$ & Nonbiscuit \\
\hline
\end{tabular}

Notes: $\mathrm{PFT}=$ perfluorocarbon tracers. $\mathrm{APC}=$ advanced piston corer, $\mathrm{XCB}=$ extended core barrel. $\mathrm{ND}=$ no data, $\mathrm{BDL}=$ below detection limit . 
Table T10. Moisture and density, Holes U1326B, U1326C, and U1326D. (Continued on next page.)

\begin{tabular}{|c|c|c|c|c|}
\hline \multirow{2}{*}{$\begin{array}{l}\text { Core, section, } \\
\text { interval }(\mathrm{cm})\end{array}$} & \multirow{2}{*}{$\begin{array}{l}\text { Depth } \\
\text { (mbsf) }\end{array}$} & \multicolumn{2}{|c|}{ Density $\left(\mathrm{g} / \mathrm{cm}^{3}\right)$} & \multirow{2}{*}{$\begin{array}{l}\text { Porosity } \\
\quad(\%)\end{array}$} \\
\hline & & Bulk & Grain & \\
\hline \multicolumn{5}{|l|}{ 311-U1326B- } \\
\hline 1H-1, 17-19 & 0.17 & 1.779 & 2.780 & 57.0 \\
\hline $1 \mathrm{H}-1,118-120$ & 1.18 & 1.867 & 2.768 & 51.6 \\
\hline \multicolumn{5}{|l|}{ 311-U1326C- } \\
\hline $1 \mathrm{H}-1,54-56$ & 0.54 & 2.036 & 2.753 & 41.5 \\
\hline $1 \mathrm{H}-1,58-60$ & 0.58 & 1.830 & 2.769 & 53.8 \\
\hline $1 \mathrm{H}-2,19-21$ & 1.69 & 1.834 & 2.742 & 52.8 \\
\hline $1 \mathrm{H}-2,30-32$ & 1.80 & 1.697 & 2.739 & 60.7 \\
\hline $1 \mathrm{H}-2,55-57$ & 2.05 & 1.754 & 2.817 & 59.3 \\
\hline $2 \mathrm{H}-2,3-5$ & 5.43 & 2.050 & 2.758 & 40.8 \\
\hline $2 \mathrm{H}-2,25-27$ & 5.65 & 1.953 & 2.738 & 45.8 \\
\hline $2 \mathrm{H}-2,48-50$ & 5.88 & 1.893 & 2.758 & 49.9 \\
\hline $2 \mathrm{H}-4,7-9$ & 8.47 & 1.882 & 2.771 & 50.9 \\
\hline $2 \mathrm{H}-4,53-55$ & 8.93 & 1.776 & 2.789 & 57.4 \\
\hline $2 \mathrm{H}-5,10-12$ & 10.00 & 1.722 & 2.746 & 59.5 \\
\hline $2 \mathrm{H}-5,56-58$ & 10.46 & 1.966 & 2.767 & 46.0 \\
\hline $2 \mathrm{H}-6,15-17$ & 11.55 & 1.853 & 2.754 & 52.1 \\
\hline $2 \mathrm{H}-6,75-77$ & 12.15 & 1.761 & 2.742 & 57.1 \\
\hline $2 \mathrm{H}-7,4-6$ & 12.94 & 1.797 & 2.746 & 55.1 \\
\hline $2 \mathrm{H}-7,49-51$ & 13.39 & 1.895 & 2.751 & 49.6 \\
\hline $3 \mathrm{H}-1,3-5$ & 13.43 & 1.943 & 2.739 & 46.4 \\
\hline $3 \mathrm{H}-1,133-135$ & 14.73 & 1.796 & 2.738 & 55.0 \\
\hline $3 \mathrm{H}-2,44-46$ & 15.34 & 1.776 & 2.740 & 56.2 \\
\hline $3 \mathrm{H}-2,123-125$ & 16.13 & 1.912 & 2.750 & 48.5 \\
\hline $3 \mathrm{H}-3,12-14$ & 16.52 & 1.781 & 2.755 & 56.3 \\
\hline $3 \mathrm{H}-3,71-73$ & 17.11 & 1.890 & 2.759 & 50.1 \\
\hline $3 \mathrm{H}-3,132-134$ & 17.72 & 2.059 & 3.768 & 62.3 \\
\hline $3 \mathrm{H}-4,35-37$ & 18.25 & 1.765 & 2.715 & 56.2 \\
\hline $3 \mathrm{H}-5,34-36$ & 19.74 & 1.794 & 2.765 & 55.8 \\
\hline $3 \mathrm{H}-5,75-77$ & 20.15 & 1.871 & 2.705 & 49.6 \\
\hline $3 \mathrm{H}-5,120-122$ & 20.60 & 2.201 & 3.710 & 56.2 \\
\hline $3 \mathrm{H}-5,138-140$ & 20.78 & 1.807 & 2.718 & 53.8 \\
\hline $3 \mathrm{H}-6,97-99$ & 21.87 & 1.780 & 2.691 & 54.6 \\
\hline $4 \mathrm{H}-1,10-12$ & 23.00 & 2.021 & 2.757 & 42.5 \\
\hline $4 \mathrm{H}-1,48-50$ & 23.38 & 2.552 & 3.828 & 45.5 \\
\hline $4 \mathrm{H}-1,99-101$ & 23.89 & 1.925 & 2.768 & 48.3 \\
\hline $4 \mathrm{H}-1,118-120$ & 24.08 & 2.116 & 2.728 & 35.9 \\
\hline $4 \mathrm{H}-3,17-19$ & 26.07 & 1.916 & 2.780 & 49.2 \\
\hline $4 \mathrm{H}-3,88-90$ & 26.78 & 2.104 & 2.741 & 37.1 \\
\hline $4 \mathrm{H}-3,142-144$ & 27.32 & 1.934 & 2.741 & 47.0 \\
\hline $4 \mathrm{H}-4,6-8$ & 27.46 & 2.006 & 2.764 & 43.6 \\
\hline $5 X-1,16-18$ & 30.56 & 1.792 & 2.795 & 56.7 \\
\hline $5 X-1,121-123$ & 31.61 & 1.795 & 2.782 & 56.2 \\
\hline $5 X-3,30-32$ & 33.62 & 1.842 & 2.774 & 53.3 \\
\hline $5 X-3,105-107$ & 34.37 & 1.837 & 2.751 & 52.9 \\
\hline $5 X-4,34-36$ & 34.99 & 1.905 & 2.765 & 49.4 \\
\hline $5 X-4,122-124$ & 35.87 & 1.920 & 2.782 & 49.0 \\
\hline $6 \mathrm{X}-1,25-27$ & 40.25 & 1.850 & 2.783 & 53.1 \\
\hline $6 \mathrm{X}-1,129-131$ & 41.29 & 1.871 & 2.755 & 51.1 \\
\hline $6 X-3,17-19$ & 43.17 & 1.996 & 2.752 & 43.7 \\
\hline $6 X-3,76-78$ & 43.76 & 1.820 & 2.718 & 53.0 \\
\hline $6 X-4,4-6$ & 44.06 & 1.949 & 2.760 & 46.7 \\
\hline $6 X-4,35-37$ & 44.37 & 2.103 & 2.830 & 40.3 \\
\hline $6 X-4,63-65$ & 44.65 & 2.059 & 2.747 & 39.9 \\
\hline $6 X-4,86-88$ & 44.88 & 2.213 & 2.843 & 34.7 \\
\hline $6 X-5,12-13$ & 45.10 & 2.097 & 2.754 & 38.0 \\
\hline $6 X-5,66-68$ & 45.64 & 1.933 & 2.725 & 46.6 \\
\hline $7 X-2,18-20$ & 51.21 & 1.868 & 2.741 & 50.8 \\
\hline $7 X-2,117-119$ & 52.20 & 1.951 & 2.874 & 49.9 \\
\hline $7 X-3,30-32$ & 52.83 & 1.995 & 2.684 & 41.5 \\
\hline $7 X-3,58-60$ & 53.11 & 1.888 & 2.745 & 49.8 \\
\hline $7 X-3,79-81$ & 53.32 & 2.005 & 2.823 & 45.5 \\
\hline $8 X-1,23-25$ & 59.63 & 1.888 & 2.709 & 48.7 \\
\hline $8 X-1,70-72$ & 60.10 & 1.950 & 2.759 & 46.6 \\
\hline $9 X-2,32-34$ & 70.92 & 1.927 & 2.748 & 47.6 \\
\hline $9 X-2,82-84$ & 71.42 & 1.983 & 2.747 & 44.3 \\
\hline $9 \mathrm{X}-2,98-100$ & 71.58 & 1.964 & 2.739 & 45.2 \\
\hline $9 X-3,10-12$ & 72.20 & 1.978 & 2.796 & 46.2 \\
\hline
\end{tabular}

\begin{tabular}{|c|c|c|c|c|}
\hline \multirow{2}{*}{$\begin{array}{l}\text { Core, section, } \\
\text { interval }(\mathrm{cm})\end{array}$} & \multirow{2}{*}{$\begin{array}{l}\text { Depth } \\
\text { (mbsf) }\end{array}$} & \multicolumn{2}{|c|}{ Density $\left(\mathrm{g} / \mathrm{cm}^{3}\right)$} & \multirow{2}{*}{$\begin{array}{l}\text { Porosity } \\
(\%)\end{array}$} \\
\hline & & Bulk & Grain & \\
\hline $9 X-4,26-28$ & 73.42 & 2.040 & 2.800 & 42.8 \\
\hline $10 X-1,12-14$ & 78.82 & 2.025 & 3.267 & 55.4 \\
\hline $10 X-1,51-53$ & 79.21 & 2.056 & 2.760 & 40.5 \\
\hline $10 X-1,57-59$ & 79.27 & 1.872 & 2.845 & 53.4 \\
\hline $10 X-1,140-142$ & 80.10 & 2.003 & 2.894 & 47.6 \\
\hline \multicolumn{5}{|l|}{ 311-U1326D- } \\
\hline $2 X-1,38-70$ & 88.78 & 1.987 & 2.902 & 48.7 \\
\hline $2 X-1,39-41$ & 88.79 & 1.892 & 2.792 & 50.9 \\
\hline $2 X-1,118-120$ & 89.58 & 1.925 & 2.784 & 48.8 \\
\hline $2 X-3,29-31$ & 91.69 & 1.934 & 2.774 & 48.0 \\
\hline $2 X-3,115-117$ & 92.55 & 1.947 & 2.747 & 46.4 \\
\hline $2 X-4,23-25$ & 93.13 & 1.900 & 2.781 & 50.1 \\
\hline $2 X-4,125-127$ & 94.15 & 1.902 & 2.747 & 49.0 \\
\hline $2 X-5,23-25$ & 94.63 & 1.969 & 2.761 & 45.6 \\
\hline $2 X-5,89-91$ & 95.29 & 1.885 & 2.779 & 51.0 \\
\hline $2 X-6,18-20$ & 96.02 & 1.904 & 2.734 & 48.5 \\
\hline $2 X-6,78-80$ & 96.62 & 1.935 & 2.699 & 45.6 \\
\hline $3 X-1,86-88$ & 98.96 & 2.059 & 2.750 & 40.0 \\
\hline $3 X-1,124-126$ & 99.34 & 2.056 & 2.758 & 40.5 \\
\hline $3 X-3,12-14$ & 101.22 & 2.008 & 2.776 & 43.8 \\
\hline $3 X-4,25-27$ & 102.85 & 1.944 & 2.764 & 47.1 \\
\hline $3 X-5,10-12$ & 103.89 & 1.955 & 2.733 & 45.5 \\
\hline $3 X-5,30-32$ & 104.09 & 2.033 & 2.763 & 42.0 \\
\hline $4 X-1,37-39$ & 108.07 & 1.790 & 2.775 & 56.3 \\
\hline $4 \mathrm{X}-1,123-125$ & 108.93 & 1.832 & 2.755 & 53.4 \\
\hline $4 X-3,27-29$ & 110.97 & 1.902 & 2.776 & 49.9 \\
\hline $4 X-4,95-97$ & 112.71 & 2.059 & 2.763 & 40.5 \\
\hline $4 X-4,128-130$ & 113.04 & 1.876 & 2.752 & 50.7 \\
\hline $4 X-5,5-7$ & 113.16 & 1.878 & 2.753 & 50.6 \\
\hline $4 X-5,54-56$ & 113.65 & 1.994 & 2.769 & 44.4 \\
\hline $4 X-5,102-104$ & 114.13 & 1.980 & 2.764 & 45.1 \\
\hline $4 X-6,16-18$ & 114.73 & 1.938 & 2.783 & 48.0 \\
\hline $5 X-1,63-65$ & 117.93 & 1.898 & 2.809 & 51.0 \\
\hline $5 X-1,113-115$ & 118.43 & 1.862 & 2.770 & 52.0 \\
\hline $5 X-2,68-70$ & 119.38 & 1.892 & 2.854 & 52.6 \\
\hline $5 X-2,90-92$ & 119.60 & 1.902 & 2.833 & 51.5 \\
\hline $5 X-4,61-63$ & 122.15 & 1.954 & 2.806 & 47.8 \\
\hline $5 X-4,110-112$ & 122.64 & 2.053 & 2.789 & 41.7 \\
\hline $5 X-5,22-24$ & 123.26 & 2.113 & 2.761 & 37.3 \\
\hline $5 X-6,23-25$ & 123.83 & 2.017 & 2.781 & 43.5 \\
\hline $6 \mathrm{X}-1,53-55$ & 127.53 & 2.007 & 2.780 & 44.0 \\
\hline $6 X-1,114-116$ & 128.14 & 1.843 & 2.732 & 52.1 \\
\hline $6 X-3,21-23$ & 130.21 & 1.985 & 2.760 & 44.6 \\
\hline $6 X-3,80-82$ & 130.80 & 1.895 & 2.779 & 50.4 \\
\hline $6 X-4,63-65$ & 131.76 & 2.002 & 2.776 & 44.2 \\
\hline $6 X-5,22-24$ & 132.67 & 2.126 & 2.806 & 38.1 \\
\hline $6 X-6,79-81$ & 134.24 & 1.979 & 2.761 & 45.0 \\
\hline $7 X-1,18-20$ & 136.78 & 1.826 & 2.743 & 53.3 \\
\hline $7 X-1,66-68$ & 137.26 & 2.008 & 2.749 & 43.0 \\
\hline $7 X-3,57-59$ & 139.31 & 1.919 & 2.788 & 49.3 \\
\hline $7 X-3,121-123$ & 139.95 & 1.947 & 2.753 & 46.6 \\
\hline $7 X-4,24-123$ & 140.43 & 1.970 & 2.783 & 46.2 \\
\hline $7 X-4,125-127$ & 141.44 & 1.988 & 2.785 & 45.2 \\
\hline $8 X-2,1-3$ & 147.81 & 1.848 & 2.719 & 51.4 \\
\hline $8 X-3,46-48$ & 149.22 & 1.798 & 2.772 & 55.7 \\
\hline $8 X-3,115-117$ & 149.91 & 1.792 & 2.751 & 55.5 \\
\hline $8 X-4,11-13$ & 150.25 & 2.086 & 2.768 & 39.1 \\
\hline $9 X-1,43-45$ & 156.33 & 1.787 & 2.646 & 53.0 \\
\hline $9 X-2,28-30$ & 157.52 & 1.928 & 2.692 & 45.8 \\
\hline $9 \times-3,5-7$ & 157.76 & 1.762 & 2.690 & 55.7 \\
\hline $9 X-4,27-29$ & 158.38 & 1.922 & 2.710 & 46.7 \\
\hline $10 X-1,36-38$ & 165.96 & 1.933 & 2.705 & 45.9 \\
\hline $10 X-1,124-126$ & 166.84 & 1.800 & 2.739 & 54.8 \\
\hline $10 X-2,22-24$ & 167.32 & 1.968 & 2.749 & 45.3 \\
\hline $10 X-2,73-75$ & 167.83 & 2.111 & 2.736 & 36.5 \\
\hline $10 X-3,34-36$ & 168.86 & 2.048 & 2.749 & 40.7 \\
\hline $10 X-3,125-127$ & 169.77 & 2.089 & 2.728 & 37.5 \\
\hline $10 X-4,24-26$ & 170.26 & 1.897 & 2.694 & 47.7 \\
\hline
\end{tabular}


Table T10 (continued).

\begin{tabular}{|c|c|c|c|c|}
\hline \multirow{2}{*}{$\begin{array}{l}\text { Core, section, } \\
\text { interval }(\mathrm{cm})\end{array}$} & \multirow{2}{*}{$\begin{array}{l}\text { Depth } \\
\text { (mbsf) }\end{array}$} & \multicolumn{2}{|c|}{ Density $\left(\mathrm{g} / \mathrm{cm}^{3}\right)$} & \multirow{2}{*}{$\begin{array}{c}\text { Porosity } \\
\text { (\%) }\end{array}$} \\
\hline & & Bulk & Grain & \\
\hline $10 X-4,76-78$ & 170.78 & 2.106 & 2.754 & 37.5 \\
\hline $11 X-1,19-21$ & 175.39 & 1.990 & 2.739 & 43.7 \\
\hline $11 X-2,22-24$ & 175.91 & 1.834 & 2.805 & 54.5 \\
\hline $11 X-2,101-103$ & 176.70 & 1.937 & 2.809 & 48.8 \\
\hline $11 X-4,22-24$ & 178.91 & 2.115 & 2.737 & 36.3 \\
\hline $11 X-4,78-80$ & 179.47 & 1.848 & 2.759 & 52.5 \\
\hline $11 X-5,30-32$ & 180.49 & 1.952 & 2.797 & 47.7 \\
\hline $11 X-5,105-107$ & 181.24 & 1.906 & 2.823 & 51.0 \\
\hline $14 X-4,113-115$ & 208.13 & 2.039 & 2.790 & 42.5 \\
\hline $14 X-5,91-93$ & 209.41 & 1.951 & 2.796 & 47.7 \\
\hline $14 X-6,51-53$ & 210.01 & 1.885 & 2.723 & 49.3 \\
\hline $15 X-1,74-76$ & 214.34 & 1.973 & 2.810 & 46.9 \\
\hline $15 X-2,91-93$ & 215.93 & 1.981 & 2.764 & 45.0 \\
\hline $15 X-3,19-21$ & 216.55 & 2.042 & 2.809 & 42.9 \\
\hline $15 X-3,88-90$ & 217.24 & 2.068 & 2.734 & 39.0 \\
\hline $15 X-5,6-8$ & 219.42 & 1.940 & 2.768 & 47.5 \\
\hline $15 X-6,38-40$ & 220.74 & 2.100 & 2.787 & 39.0 \\
\hline $16 X-1,35-37$ & 223.65 & 1.923 & 2.753 & 48.0 \\
\hline $16 X-1,119-121$ & 224.49 & 1.999 & 2.785 & 44.6 \\
\hline $16 X-3,78-80$ & 227.08 & 2.054 & 2.785 & 41.5 \\
\hline
\end{tabular}

Table T11. Compressional wave velocity, Holes U1326B and U1326C.

\begin{tabular}{lcccc}
\hline \multirow{2}{*}{$\begin{array}{c}\text { Core, section, } \\
\text { interval (cm) }\end{array}$} & $\begin{array}{l}\text { Depth } \\
\text { (mbsf) }\end{array}$ & \multicolumn{3}{c}{ Velocity (m/s) } \\
\cline { 4 - 5 } & & PWS1 & PWS2 & PWS3 \\
\hline $311-$ U1326B- & & & & \\
$1 \mathrm{H}-1,4$ & 0.04 & 1589.9 & & \\
$1 \mathrm{H}-1,4$ & 0.04 & & & 1487.1 \\
$1 \mathrm{H}-1,69$ & 0.69 & 1549.3 & & \\
$1 \mathrm{H}-1,69$ & 0.69 & & 1556.9 & \\
$1 \mathrm{H}-1,69$ & 0.69 & & & 1547.3 \\
$1 \mathrm{H}-1,120$ & 1.20 & & & 1503.6 \\
$311-\mathrm{U} 1326 \mathrm{C}-$ & & & & \\
$1 \mathrm{H}-2,45$ & 1.95 & 1537.2 & & \\
$1 \mathrm{H}-2,45$ & 1.95 & & & 1517.2 \\
$1 \mathrm{H}-2,59$ & 2.09 & & & 1570.9 \\
\hline
\end{tabular}

Note: $P W S=P$-wave sensor. 
Table T12. Torvane shear strength, Holes U1326C and U1326D. (See table note. Continued on next page.)

\begin{tabular}{|c|c|c|c|}
\hline $\begin{array}{l}\text { Core, section, } \\
\text { interval }(\mathrm{cm})\end{array}$ & $\begin{array}{l}\text { Depth } \\
\text { (mbsf) }\end{array}$ & $\begin{array}{l}\text { Torvane shear } \\
\text { strength }(\mathrm{kPa})\end{array}$ & $\begin{array}{l}\text { Torvane } \\
\text { size }\end{array}$ \\
\hline \multicolumn{4}{|l|}{ 311-U1326C- } \\
\hline $1 \mathrm{H}-2,61-63$ & 2.11 & 31 & M \\
\hline $2 \mathrm{H}-2,16-18$ & 5.56 & 15 & M \\
\hline $2 \mathrm{H}-2,51-53$ & 5.91 & 51 & M \\
\hline $2 \mathrm{H}-4,12-14$ & 8.52 & 60 & M \\
\hline $2 \mathrm{H}-4,48-50$ & 8.88 & 75 & M \\
\hline $2 \mathrm{H}-5,18-20$ & 10.08 & 83 & M \\
\hline $2 \mathrm{H}-5,51-53$ & 10.41 & 82 & M \\
\hline $2 \mathrm{H}-6,10-12$ & 11.50 & 80 & M \\
\hline $2 \mathrm{H}-7,11-13$ & 13.01 & 75 & M \\
\hline $2 \mathrm{H}-7,41-43$ & 13.31 & 65 & M \\
\hline $2 \mathrm{H}-2,10-12$ & 5.50 & 10 & $\mathrm{~s}$ \\
\hline $2 \mathrm{H}-2,42-44$ & 5.82 & 70 & S \\
\hline $2 \mathrm{H}-4,15-17$ & 8.55 & 80 & S \\
\hline $2 \mathrm{H}-4,44-46$ & 8.84 & 92.5 & S \\
\hline $2 \mathrm{H}-5,14-16$ & 10.04 & 67.5 & s \\
\hline $2 \mathrm{H}-5,48-50$ & 10.38 & 110 & S \\
\hline $2 \mathrm{H}-6,19-21$ & 11.59 & 87.5 & s \\
\hline $2 \mathrm{H}-6,53-55$ & 11.93 & 80 & S \\
\hline $2 \mathrm{H}-7,15-17$ & 13.05 & 100 & $S$ \\
\hline $3 \mathrm{H}-1,9-11$ & 13.49 & 39 & M \\
\hline $3 \mathrm{H}-1,93-95$ & 14.33 & 67 & M \\
\hline $3 \mathrm{H}-1,131-132$ & 14.71 & 62 & M \\
\hline $3 \mathrm{H}-1,6-8$ & 13.46 & 30 & $\mathrm{~s}$ \\
\hline $3 \mathrm{H}-1,88-90$ & 14.28 & 72.5 & s \\
\hline $3 \mathrm{H}-1,137-139$ & 14.77 & 85 & S \\
\hline $3 \mathrm{H}-2,40-42$ & 15.30 & 75 & S \\
\hline $3 \mathrm{H}-2,121-123$ & 16.11 & 55 & $S$ \\
\hline $3 \mathrm{H}-2,48-50$ & 15.38 & 62 & M \\
\hline $3 \mathrm{H}-2,119-121$ & 16.09 & 37 & M \\
\hline $3 \mathrm{H}-3,17-19$ & 16.57 & 80 & M \\
\hline $3 \mathrm{H}-3,129-131$ & 17.69 & 73 & M \\
\hline $3 \mathrm{H}-3,20-21$ & 16.60 & 35 & M \\
\hline $3 \mathrm{H}-3,134-136$ & 17.74 & 23 & M \\
\hline $3 \mathrm{H}-4,39-41$ & 18.29 & 20 & M \\
\hline $3 \mathrm{H}-4,39-41$ & 18.29 & 63 & M \\
\hline $3 \mathrm{H}-5,38-40$ & 19.78 & 75 & M \\
\hline $3 \mathrm{H}-5,83-85$ & 20.23 & 86 & M \\
\hline $3 \mathrm{H}-5,142-144$ & 20.82 & 85 & M \\
\hline $3 \mathrm{H}-5,33-35$ & 19.73 & 62.5 & $S$ \\
\hline $3 \mathrm{H}-5,90-92$ & 20.30 & 95 & s \\
\hline $3 \mathrm{H}-5,135-137$ & 20.75 & 100 & s \\
\hline $3 \mathrm{H}-6,45-47$ & 21.35 & 97.5 & s \\
\hline $3 \mathrm{H}-6,96-98$ & 21.86 & 105 & $S$ \\
\hline $3 \mathrm{H}-6,48-50$ & 21.38 & 75 & M \\
\hline $3 \mathrm{H}-6,105-107$ & 21.95 & 75 & M \\
\hline $4 \mathrm{H}-1,45-47$ & 23.35 & 5 & M \\
\hline $4 \mathrm{H}-1,94-96$ & 23.84 & 70 & M \\
\hline $4 \mathrm{H}-2,35-37$ & 24.75 & 78 & M \\
\hline $5 X-1,21-23$ & 30.61 & 19 & M \\
\hline 5X-1, 129-131 & 31.69 & 25 & M \\
\hline $5 X-3,37-39$ & 33.69 & 24 & M \\
\hline $5 X-3,108-110$ & 34.40 & 37 & M \\
\hline $5 X-4,38-40$ & 35.03 & 55 & M \\
\hline $5 X-4,112-114$ & 35.77 & 49 & M \\
\hline $5 X-4,41-43$ & 35.06 & 55 & $S$ \\
\hline $5 X-4,115-117$ & 35.80 & 70 & $S$ \\
\hline $6 X-1,33-35$ & 40.33 & 27 & M \\
\hline $6 \mathrm{X}-1,126-128$ & 41.26 & 50 & M \\
\hline $6 X-3,22-24$ & 43.22 & 74 & M \\
\hline $6 X-3,81-83$ & 43.81 & 36 & M \\
\hline $6 X-4,9-11$ & 44.11 & 16 & M \\
\hline $6 X-4,30-32$ & 44.32 & 16 & M \\
\hline $6 X-4,59-61$ & 44.61 & 13 & M \\
\hline $6 X-5,18-20$ & 45.16 & 70 & M \\
\hline $6 X-1,121-123$ & 41.21 & 55 & $S$ \\
\hline $6 X-3,12-14$ & 43.12 & 82.5 & s \\
\hline $6 X-3,71-73$ & 43.71 & 42.5 & s \\
\hline $6 X-4,16-18$ & 44.18 & 40 & S \\
\hline
\end{tabular}

\begin{tabular}{|c|c|c|c|}
\hline $\begin{array}{l}\text { Core, section, } \\
\text { interval }(\mathrm{cm})\end{array}$ & $\begin{array}{l}\text { Depth } \\
\text { (mbsf) }\end{array}$ & $\begin{array}{l}\text { Torvane shear } \\
\text { strength }(\mathrm{kPa})\end{array}$ & $\begin{array}{l}\text { Torvane } \\
\text { size }\end{array}$ \\
\hline $6 X-5,22-24$ & 45.20 & 97.5 & $\mathrm{~s}$ \\
\hline $6 X-5,73-75$ & 45.71 & 125 & $\mathrm{~s}$ \\
\hline $7 X-2,73-75$ & 51.76 & 56 & $\mathrm{M}$ \\
\hline $7 X-2,90-92$ & 51.93 & 75 & $S$ \\
\hline $7 X-3,67-69$ & 53.20 & 56 & M \\
\hline $7 X-3,52-54$ & 53.05 & 55 & $S$ \\
\hline $9 X-2,85-87$ & 71.45 & 37 & M \\
\hline $9 X-2,93-95$ & 71.53 & 20 & $\mathrm{~S}$ \\
\hline $9 X-3,53-55$ & 72.63 & 37 & M \\
\hline $9 \mathrm{X}-3,40-41$ & 72.50 & 45 & $\mathrm{~S}$ \\
\hline $9 X-4,91-93$ & 74.07 & 83 & M \\
\hline $9 X-4,54-56$ & 73.70 & 105 & $S$ \\
\hline $10 X-1,98-100$ & 79.68 & 32 & M \\
\hline $10 X-1,26-28$ & 78.96 & 47.5 & $S$ \\
\hline \multicolumn{4}{|l|}{ 311-U1326D- } \\
\hline $2 X-1,45-47$ & 88.85 & 41 & $\mathrm{M}$ \\
\hline $2 X-1,135-137$ & 89.75 & 82 & M \\
\hline $2 X-1,112-114$ & 89.52 & 13 & M \\
\hline $2 X-3,35-37$ & 91.75 & 58 & M \\
\hline $2 X-3,119-121$ & 92.59 & 73 & M \\
\hline $2 X-4,20-22$ & 93.10 & 77 & M \\
\hline $2 X-5,19-21$ & 94.59 & 69 & M \\
\hline $2 X-5,84-86$ & 95.24 & 80 & M \\
\hline $2 X-6,27-29$ & 96.11 & 92 & M \\
\hline $2 X-6,74-76$ & 96.58 & 89 & M \\
\hline $2 X-1,49-51$ & 88.89 & 47.5 & $\mathrm{~s}$ \\
\hline $2 X-1,141-143$ & 89.81 & 95 & $\mathrm{~s}$ \\
\hline $2 X-3,38-40$ & 91.78 & 82.5 & S \\
\hline $2 X-3,119-121$ & 92.59 & 82.5 & $\mathrm{~s}$ \\
\hline $2 X-4,132-134$ & 94.22 & 112.5 & $\mathrm{~s}$ \\
\hline $2 X-5,28-30$ & 94.68 & 130 & $\mathrm{~s}$ \\
\hline $2 X-5,80-82$ & 95.20 & 122.5 & $\mathrm{~s}$ \\
\hline $2 X-6,29-31$ & 96.13 & 97.5 & s \\
\hline $2 X-6,81-83$ & 96.65 & 100 & $\mathrm{~s}$ \\
\hline $3 X-1,52-55$ & 98.62 & 28 & M \\
\hline $3 X-1,141-143$ & 99.51 & 38 & M \\
\hline $3 X-2,19-21$ & 99.79 & 175 & $\mathrm{~S}$ \\
\hline $3 X-2,65-67$ & 100.25 & 200 & s \\
\hline $3 X-2,109-111$ & 100.69 & 202.5 & S \\
\hline $3 X-4,14-16$ & 102.74 & 202.5 & s \\
\hline $3 X-4,51-53$ & 103.11 & 155 & s \\
\hline $3 X-5,6-8$ & 103.85 & 210 & $\mathrm{~s}$ \\
\hline $3 X-5,36-38$ & 104.15 & 237.5 & $\mathrm{~s}$ \\
\hline $3 X-5,53-55$ & 104.32 & 225 & $S$ \\
\hline $4 X-1,33-35$ & 108.03 & 22 & M \\
\hline $4 X-1,120-122$ & 108.90 & 30 & M \\
\hline $4 X-3,32-34$ & 111.02 & 63 & M \\
\hline $4 X-4,24-26$ & 112.00 & 65 & M \\
\hline $4 X-4,85-86$ & 112.61 & 62 & M \\
\hline $4 X-4,118-120$ & 112.94 & 42 & M \\
\hline $4 X-5,11-13$ & 113.22 & 48 & M \\
\hline $4 X-5,50-52$ & 113.61 & 52 & M \\
\hline $4 X-5,25-27$ & 113.36 & 66 & M \\
\hline $4 X-1,42-44$ & 108.12 & 45 & $\mathrm{~s}$ \\
\hline $4 \mathrm{X}-1,128-130$ & 108.98 & 37.5 & S \\
\hline $4 X-3,30-32$ & 111.00 & 62.5 & S \\
\hline $4 X-4,28-30$ & 112.04 & 62.5 & $\mathrm{~s}$ \\
\hline 4X-4, 99-101 & 112.75 & 25 & $\mathrm{~s}$ \\
\hline $4 X-4,117-119$ & 112.93 & 55 & $\mathrm{~s}$ \\
\hline $4 X-5,9-11$ & 113.20 & 50 & $\mathrm{~s}$ \\
\hline $4 X-5,48-50$ & 113.59 & 82.5 & $\mathrm{~s}$ \\
\hline $4 X-6,28-30$ & 114.85 & 65 & $S$ \\
\hline $5 X-1,37.5-39$ & 117.68 & 35 & $M$ \\
\hline $5 X-1,66-68$ & 117.96 & 37.5 & $\mathrm{~S}$ \\
\hline $5 X-2,28-30$ & 118.98 & 49 & M \\
\hline $5 X-2,65-67$ & 119.35 & 62.5 & $\mathrm{~s}$ \\
\hline $5 X-4,83-85$ & 122.37 & 41 & M \\
\hline $5 X-4,91-93$ & 122.45 & 50 & $\mathrm{~s}$ \\
\hline $5 X-5,10-12$ & 123.14 & 11 & M \\
\hline
\end{tabular}


Table T12 (continued).

\begin{tabular}{|c|c|c|c|}
\hline $\begin{array}{l}\text { Core, section, } \\
\text { interval }(\mathrm{cm})\end{array}$ & $\begin{array}{l}\text { Depth } \\
\text { (mbsf) }\end{array}$ & $\begin{array}{l}\text { Torvane shear } \\
\text { strength }(\mathrm{kPa})\end{array}$ & $\begin{array}{c}\text { Torvane } \\
\text { size }\end{array}$ \\
\hline $5 X-5,2-4$ & 123.06 & 12.5 & $S$ \\
\hline $5 X-6,82-84$ & 124.42 & 60 & M \\
\hline $5 X-6,79-81$ & 124.39 & 90 & $S$ \\
\hline $6 X-1,101-103$ & 128.01 & 20 & M \\
\hline $6 X-1,117-119$ & 128.17 & 40 & $S$ \\
\hline $6 X-3,30-32$ & 130.30 & 25 & M \\
\hline $6 X-3,56-58$ & 130.56 & 57.5 & $S$ \\
\hline $6 X-4,35-37$ & 131.48 & 75 & M \\
\hline $6 X-4,32-34$ & 131.45 & 100 & $S$ \\
\hline $6 X-5,73-75$ & 133.18 & 48 & M \\
\hline $6 X-5,77-79$ & 133.22 & 35 & $S$ \\
\hline $6 X-6,36-38$ & 133.81 & 36 & M \\
\hline $6 X-6,28-30$ & 133.73 & 45 & $S$ \\
\hline 7X-4, 1.4-1.6 & 140.20 & 57.5 & $S$ \\
\hline 7X-4, 107-109 & 141.26 & 48 & M \\
\hline $8 X-2,20-22$ & 148.00 & 31 & M \\
\hline $8 X-2,25-26$ & 148.05 & 72.5 & $S$ \\
\hline $8 X-3,81-83$ & 149.57 & 40 & $\mathrm{M}$ \\
\hline $8 X-3,93-95$ & 149.69 & 67.5 & $S$ \\
\hline $8 X-4,18-20$ & 150.32 & 25 & $\mathrm{M}$ \\
\hline $8 X-4,24-26$ & 150.38 & 57.5 & $S$ \\
\hline $9 X-1,30-32$ & 156.20 & 20 & M \\
\hline $9 X-4,13-15$ & 158.24 & 27 & M \\
\hline $9 X-4,10-12$ & 158.21 & 25 & $S$ \\
\hline $10 X-1,54-56$ & 166.14 & 25 & $\mathrm{M}$ \\
\hline $10 X-1,118-120$ & 166.78 & 43 & $\mathrm{M}$ \\
\hline $10 X-2,26-28$ & 167.36 & 47 & $\mathrm{M}$ \\
\hline $10 X-2,66-68$ & 167.76 & 23 & $\mathrm{M}$ \\
\hline $10 X-4,23-25$ & 170.25 & 54 & $\mathrm{M}$ \\
\hline $10 X-4,84-86$ & 170.86 & 60 & $\mathrm{M}$ \\
\hline $10 X-3,29-31$ & 168.81 & 30 & $\mathrm{M}$ \\
\hline $10 X-2,30-32$ & 167.40 & 60 & $S$ \\
\hline $10 X-2,76-78$ & 167.86 & 25 & $S$ \\
\hline $10 X-3,25-28$ & 168.77 & 37.5 & $S$ \\
\hline $10 X-3,129-131$ & 169.81 & 50 & $S$ \\
\hline $10 X-4,91-93$ & 170.93 & 40 & $S$ \\
\hline $11 X-1,24-26$ & 175.44 & 10 & $\mathrm{M}$ \\
\hline $11 X-2,102-104$ & 176.71 & 67 & $\mathrm{M}$ \\
\hline $11 X-4,15-17$ & 178.84 & 33 & $\mathrm{M}$ \\
\hline $11 X-5,25-27$ & 180.44 & 95 & $S$ \\
\hline $11 X-5,102-104$ & 181.21 & 177.5 & $S$ \\
\hline
\end{tabular}

\begin{tabular}{|c|c|c|c|}
\hline $\begin{array}{l}\text { Core, section, } \\
\text { interval }(\mathrm{cm})\end{array}$ & $\begin{array}{l}\text { Depth } \\
\text { (mbsf) }\end{array}$ & $\begin{array}{l}\text { Torvane shear } \\
\text { strength }(\mathrm{kPa})\end{array}$ & $\begin{array}{l}\text { Torvane } \\
\text { size }\end{array}$ \\
\hline $12 X-1,14-16$ & 184.94 & 25 & M \\
\hline $12 X-1,42-44$ & 185.22 & 28 & $M$ \\
\hline $12 X-2,26-28$ & 186.31 & 70 & M \\
\hline $12 X-2,103-105$ & 187.08 & 77 & $\mathrm{M}$ \\
\hline $12 X-4,53-55$ & 189.58 & 57 & $\mathrm{M}$ \\
\hline $12 X-5,32-34$ & 190.04 & 15 & $\mathrm{M}$ \\
\hline $12 X-2,26-28$ & 186.31 & 70 & $S$ \\
\hline $12 X-2,91-93$ & 186.96 & 65 & $S$ \\
\hline $12 X-4,23-25$ & 189.28 & 80 & $S$ \\
\hline $12 X-4,50-52$ & 189.55 & 55 & $S$ \\
\hline $12 X-5,22-24$ & 189.94 & 42.5 & $S$ \\
\hline $13 X-1,36-38$ & 194.76 & 45 & $M$ \\
\hline $13 X-3,15-17$ & 197.15 & 20 & $M$ \\
\hline $13 X-4,37-39$ & 198.37 & 25 & M \\
\hline $14 X-1,62-64$ & 204.62 & 25 & M \\
\hline $14 X-3,13-15$ & 206.40 & 41 & M \\
\hline $14 X-4,119-121$ & 208.19 & 40 & M \\
\hline $14 X-5,95-97$ & 209.45 & 50 & $\mathrm{M}$ \\
\hline $14 X-6,46-48$ & 209.96 & 95 & $S$ \\
\hline $15 X-1,65-67$ & 214.25 & 100 & $S$ \\
\hline $15 X-2,96-98$ & 215.98 & 122.5 & $S$ \\
\hline $15 X-3,23-25$ & 216.59 & 92.5 & $S$ \\
\hline $15 X-3,81-83$ & 217.17 & 80 & $S$ \\
\hline $15 X-5,2-4$ & 219.38 & 32.5 & $S$ \\
\hline $15 X-6,36-38$ & 220.72 & 87.5 & $S$ \\
\hline $16 X-1,112-114$ & 224.42 & 90 & $S$ \\
\hline $16 X-3,75-77$ & 227.05 & 85 & $S$ \\
\hline $16 X-4,12-14$ & 227.92 & 125 & $S$ \\
\hline $16 X-4,89-91$ & 228.69 & 162.5 & $S$ \\
\hline $16 X-5,78-80$ & 229.68 & 167.5 & $S$ \\
\hline $17 X-1,115-117$ & 234.05 & 37.5 & $S$ \\
\hline $17 X-3,129-131$ & 237.19 & 82.5 & $S$ \\
\hline $17 X-4,36-38$ & 237.76 & 62.5 & $S$ \\
\hline $17 X-5,75-77$ & 239.65 & 82.5 & $S$ \\
\hline $17 X-6,53-55$ & 240.87 & 70 & $S$ \\
\hline $18 X-2,17-19$ & 243.82 & 45 & $S$ \\
\hline $20 X-3,30-32$ & 264.05 & 50 & $S$ \\
\hline $20 X-4,31-33$ & 265.35 & 37.5 & $S$ \\
\hline $20 X-5,49-51$ & 267.03 & 22 & M \\
\hline $20 X-7,44-46$ & 269.48 & 75 & $S$ \\
\hline
\end{tabular}

Note: $\mathrm{L}=$ large $(4.8 \mathrm{~cm}$ diameter $), \mathrm{M}=$ medium $(2.5 \mathrm{~cm}$ diameter $), \mathrm{S}=$ small $(1.9 \mathrm{~cm}$ diameter $)$. 
Table T13. AVS shear strength, Holes U1326C and U1326D.

\begin{tabular}{|c|c|c|c|c|}
\hline \multirow{2}{*}{$\begin{array}{l}\text { Core, section, } \\
\text { interval }(\mathrm{cm})\end{array}$} & \multirow{2}{*}{$\begin{array}{l}\text { Depth } \\
\text { (mbsf) }\end{array}$} & \multirow{2}{*}{$\begin{array}{l}\text { Vane } \\
\text { size }\end{array}$} & \multicolumn{2}{|c|}{ Shear strength $(\mathrm{kPa})$} \\
\hline & & & Peak & Residual \\
\hline \multicolumn{5}{|l|}{ 311-U1326C- } \\
\hline $1 \mathrm{H}-2,33$ & 1.83 & B & 26.7 & 13.4 \\
\hline $2 \mathrm{H}-1,46$ & 4.36 & B & 42.0 & 37.2 \\
\hline $2 \mathrm{H}-2,34$ & 5.74 & B & 45.0 & 10.4 \\
\hline $2 \mathrm{H}-5,17$ & 10.07 & B & 61.5 & 38.2 \\
\hline $2 \mathrm{H}-6,35$ & 11.75 & B & 72.2 & 28.0 \\
\hline $2 \mathrm{H}-7,8$ & 12.98 & B & 81.9 & 33.5 \\
\hline $3 \mathrm{H}-1,56$ & 13.96 & B & 31.3 & 26.0 \\
\hline $3 \mathrm{H}-1,91$ & 14.31 & B & 47.2 & 35.2 \\
\hline $3 \mathrm{H}-2,59$ & 15.49 & B & 52.3 & 35.5 \\
\hline $3 \mathrm{H}-2,109$ & 15.99 & B & 59.0 & 30.1 \\
\hline $3 \mathrm{H}-3,27$ & 16.67 & B & 74.8 & 51.8 \\
\hline $3 \mathrm{H}-3,111$ & 17.51 & B & 71.9 & 53.3 \\
\hline $3 \mathrm{H}-4,33$ & 18.23 & B & 66.1 & 50.5 \\
\hline $3 \mathrm{H}-5,32$ & 19.72 & B & 60.7 & 44.5 \\
\hline $3 \mathrm{H}-5,134$ & 20.74 & B & 74.2 & 45.4 \\
\hline $3 \mathrm{H}-6,39$ & 21.29 & B & 85.6 & 48.9 \\
\hline $3 \mathrm{H}-6,102$ & 21.92 & B & 63.7 & 47.2 \\
\hline $4 \mathrm{H}-1,79$ & 23.69 & B & 65.4 & 19.5 \\
\hline $4 \mathrm{H}-3,32$ & 26.22 & B & 44.2 & 26.2 \\
\hline $5 X-1,119$ & 31.59 & A & 31.5 & 27.3 \\
\hline $5 X-3,114$ & 34.46 & A & 50.3 & 39.4 \\
\hline $5 X-4,31$ & 34.96 & A & 59.4 & 50.3 \\
\hline $5 X-4,76$ & 35.41 & A & 56.2 & 44.1 \\
\hline $6 X-1,110$ & 41.10 & A & 80.9 & 44.3 \\
\hline $6 X-3,33$ & 43.33 & A & 76.5 & 62.9 \\
\hline $6 X-4,64$ & 44.66 & A & 7.0 & 4.7 \\
\hline $6 X-5,14$ & 45.12 & A & 109.1 & 67.6 \\
\hline $7 X-2,88$ & 51.91 & A & 65.0 & 49.9 \\
\hline $7 X-2,130$ & 52.33 & A & 44.1 & 35.9 \\
\hline $8 X-1,80$ & 60.20 & A & 7.2 & 5.6 \\
\hline $9 X-2,58$ & 71.18 & B & 35.2 & 20.7 \\
\hline $9 X-3,30$ & 72.40 & B & 43.8 & 19.2 \\
\hline $9 X-4,40$ & 73.56 & B & 84.8 & 21.9 \\
\hline $10 X-1,24$ & 78.94 & B & 22.1 & 12.7 \\
\hline \multicolumn{5}{|l|}{ 311-U1326D- } \\
\hline $2 X-1,138$ & 89.78 & A & 72.7 & 46.9 \\
\hline $2 X-3,11$ & 91.51 & A & 87.2 & 47.1 \\
\hline $2 X-4,137$ & 94.27 & A & 71.6 & 55.5 \\
\hline $2 X-5,31$ & 94.71 & A & 103.3 & 70.9 \\
\hline $2 X-6,59$ & 96.43 & A & 84.4 & 60.1 \\
\hline $2 X-6,37$ & 96.21 & A & 115.6 & 79.5 \\
\hline $3 X-1,71$ & 98.81 & A & 6.3 & 2.8 \\
\hline $3 X-3,61$ & 101.71 & A & 121.7 & 82.5 \\
\hline $3 X-4,21$ & 102.81 & A & 155.7 & 78.3 \\
\hline $3 X-5,36$ & 104.15 & A & 345.2 & 110.0 \\
\hline $3 X-5,46$ & 104.25 & A & 219.1 & 114.7 \\
\hline $3 X-5,24$ & 104.03 & A & 171.6 & 126.8 \\
\hline $4 X-1,56$ & 108.26 & A & 25.2 & 22.4 \\
\hline $4 X-3,25$ & 110.95 & A & 55.7 & 46.9 \\
\hline $4 X-4,60$ & 112.36 & A & 88.6 & 65.5 \\
\hline
\end{tabular}

\begin{tabular}{|c|c|c|c|c|}
\hline \multirow{2}{*}{$\begin{array}{l}\text { Core, section, } \\
\text { interval (cm) }\end{array}$} & \multirow{2}{*}{$\begin{array}{l}\text { Depth } \\
\text { (mbsf) }\end{array}$} & \multirow{2}{*}{$\begin{array}{l}\text { Vane } \\
\text { size }\end{array}$} & \multicolumn{2}{|c|}{ Shear strength $(\mathrm{kPa})$} \\
\hline & & & Peak & Residual \\
\hline $4 X-5,33$ & 113.44 & A & 74.8 & 63.4 \\
\hline $4 X-6,32$ & 114.89 & A & 66.4 & 53.4 \\
\hline $5 X-1,104$ & 118.34 & B & 21.6 & 12.9 \\
\hline $5 X-2,97$ & 119.67 & B & 36.9 & 11.0 \\
\hline $5 X-4,45$ & 121.99 & B & 36.7 & 15.6 \\
\hline $5 X-5,7$ & 123.11 & B & 18.9 & 7.6 \\
\hline $5 X-6,73$ & 124.33 & B & 56.2 & 13.9 \\
\hline $6 X-1,68$ & 127.68 & B & 21.2 & 9.2 \\
\hline $6 X-3,59$ & 130.59 & B & 42.8 & 16.3 \\
\hline $6 X-4,42$ & 131.55 & B & 35.7 & 16.3 \\
\hline $6 X-5,56$ & 133.01 & B & 58.6 & 15.6 \\
\hline $6 X-6,33$ & 133.78 & B & 49.1 & 19.0 \\
\hline $7 X-3,117$ & 139.91 & B & 33.0 & 13.9 \\
\hline $7 X-4,41$ & 140.60 & B & 31.4 & 11.7 \\
\hline $8 X-2,14$ & 147.94 & B & 34.7 & 12.2 \\
\hline $8 X-3,86$ & 149.62 & B & 41.5 & 8.3 \\
\hline $8 X-4,37$ & 156.32 & B & 83.2 & 18.0 \\
\hline $9 X-1,42$ & 158.32 & B & 11.9 & -0.7 \\
\hline $9 X-4,21$ & 167.61 & B & 38.1 & 17.8 \\
\hline $10 X-2,51$ & 168.69 & B & 43.0 & 34.7 \\
\hline $10 X-3,17$ & 170.72 & B & 53.3 & 32.8 \\
\hline $10 X-4,70$ & 176.53 & B & 67.6 & 41.8 \\
\hline $11 X-2,84$ & 178.82 & A & 23.3 & 20.5 \\
\hline $11 X-4,13$ & 180.42 & A & 19.3 & 18.6 \\
\hline $11 X-5,23$ & 181.31 & A & 90.4 & 33.6 \\
\hline $11 X-5,112$ & 185.07 & A & 203.0 & 86.5 \\
\hline $12 X-1,27$ & 186.43 & A & 24.0 & 16.8 \\
\hline $12 X-2,38$ & 189.35 & A & 81.3 & 46.6 \\
\hline $12 X-4,30$ & 190.41 & A & 31.0 & 24.2 \\
\hline $12 X-5,69$ & 194.66 & A & 44.1 & 15.6 \\
\hline $13 X-1,26$ & 207.30 & A & 58.3 & 28.2 \\
\hline $14 X-4,30$ & 207.95 & A & 48.5 & 38.7 \\
\hline $14 X-4,95$ & 210.01 & A & 56.6 & 35.7 \\
\hline $14 X-6,51$ & 216.08 & A & 117.9 & 85.5 \\
\hline $15 X-2,106$ & 216.95 & A & 107.7 & 85.3 \\
\hline $15 X-3,59$ & 219.61 & A & 51.0 & 42.9 \\
\hline $15 X-5,25$ & 220.62 & A & 96.3 & 75.1 \\
\hline $15 X-6,26$ & 226.93 & A & 75.3 & 64.8 \\
\hline $16 X-3,63$ & 228.02 & A & 110.3 & 99.8 \\
\hline $16 X-4,22$ & 229.11 & A & 96.7 & 75.5 \\
\hline 16X-5, 21 & 234.12 & A & 104.2 & 48.9 \\
\hline $17 X-1,122$ & 237.30 & A & 31.2 & 4.4 \\
\hline $17 X-3,140$ & 238.15 & A & 72.7 & 21.9 \\
\hline $17 X-4,75$ & 239.76 & $A$ & 136.8 & 46.6 \\
\hline $17 X-5,86$ & 240.50 & A & 108.9 & 38.2 \\
\hline $17 X-6,16$ & 243.90 & A & 115.8 & 28.4 \\
\hline $18 X-2,25$ & 263.93 & A & 42.7 & 4.2 \\
\hline $20 X-3,18$ & 267.10 & A & 86.7 & 4.7 \\
\hline $20 X-5,56$ & 269.40 & B & 62.3 & 17.3 \\
\hline $20 X-7,36$ & & A & 76.9 & 16.1 \\
\hline
\end{tabular}

Notes: $\mathrm{A}=$ small vane, $\mathrm{B}=$ medium vane. AVS values were calibrated for the spring constant used to calculate shear strength. 
Table T14. Contact resistivity, Holes U1326B, U1326C, and U1326D. (Continued on next two pages.)

\begin{tabular}{|c|c|c|c|c|c|c|c|c|c|c|c|}
\hline $\begin{array}{l}\text { Core, section, } \\
\text { interval }(\mathrm{cm})\end{array}$ & $\begin{array}{l}\text { Depth } \\
\text { (mbsf) }\end{array}$ & $\begin{array}{l}\text { Resistivity } \\
(\Omega \mathrm{m})\end{array}$ & $\begin{array}{l}\text { Core, section, } \\
\text { interval }(\mathrm{cm})\end{array}$ & $\begin{array}{l}\text { Depth } \\
\text { (mbsf) }\end{array}$ & $\begin{array}{l}\text { Resistivity } \\
(\Omega \mathrm{m})\end{array}$ & $\begin{array}{l}\text { Core, section, } \\
\text { interval }(\mathrm{cm})\end{array}$ & $\begin{array}{l}\text { Depth } \\
\text { (mbsf) }\end{array}$ & $\begin{array}{l}\text { Resistivity } \\
(\Omega \mathrm{m})\end{array}$ & $\begin{array}{l}\text { Core, section, } \\
\text { interval }(\mathrm{cm})\end{array}$ & $\begin{array}{l}\text { Depth } \\
\text { (mbsf) }\end{array}$ & $\begin{array}{l}\text { Resistivity } \\
(\Omega \mathrm{m})\end{array}$ \\
\hline Perpendicular & & & $2 \mathrm{H}-6,21$ & 11.61 & 1.075 & $3 \mathrm{H}-5,138$ & 20.78 & 1.206 & $5 X-1,145$ & 31.85 & 0.784 \\
\hline 311-U1326B- & & & $2 \mathrm{H}-6,30$ & 11.70 & 0.912 & $3 \mathrm{H}-5,148$ & 20.88 & 0.944 & $5 X-3,10$ & 33.42 & 0.773 \\
\hline $1 \mathrm{H}-1,8$ & 0.08 & 0.513 & $2 \mathrm{H}-6,36$ & 11.76 & 0.953 & $3 \mathrm{H}-6,5$ & 20.95 & 0.995 & $5 X-3,20$ & 33.52 & 0.671 \\
\hline $1 \mathrm{H}-1,18$ & 0.18 & 0.539 & $2 \mathrm{H}-6,45$ & 11.85 & 0.925 & $3 \mathrm{H}-6,15$ & 21.05 & 1.474 & $5 X-3,33$ & 33.65 & 0.816 \\
\hline $1 \mathrm{H}-1,28$ & 0.28 & 0.572 & $2 \mathrm{H}-6,50$ & 11.90 & 0.913 & $3 \mathrm{H}-6,23$ & 21.13 & 1.318 & $5 X-3,43$ & 33.75 & 0.851 \\
\hline $1 \mathrm{H}-1,38$ & 0.38 & 0.671 & $2 \mathrm{H}-6,59$ & 11.99 & 1.022 & $3 \mathrm{H}-6,33$ & 21.23 & 1.171 & $5 X-3,61$ & 33.93 & 0.941 \\
\hline $1 \mathrm{H}-1,48$ & 0.48 & 0.522 & $2 \mathrm{H}-6,67$ & 12.07 & 1.093 & $3 \mathrm{H}-6,43$ & 21.33 & 1.127 & $5 X-3,71$ & 34.03 & 0.685 \\
\hline $1 \mathrm{H}-1,49$ & 0.49 & 0.499 & $2 \mathrm{H}-6,75$ & 12.15 & 0.855 & $3 \mathrm{H}-6,53$ & 21.43 & 0.958 & $5 X-3,92$ & 34.24 & 0.821 \\
\hline $1 \mathrm{H}-1,54$ & 0.54 & 0.645 & $2 \mathrm{H}-7,5$ & 12.95 & 0.923 & $3 \mathrm{H}-6,59$ & 21.49 & 0.803 & $5 X-3,106$ & 34.38 & 0.901 \\
\hline $1 \mathrm{H}-1,58$ & 0.58 & 0.566 & $2 \mathrm{H}-7,10$ & 13.00 & 0.829 & $3 \mathrm{H}-6,69$ & 21.59 & 0.917 & $5 X-3,116$ & 34.48 & 0.936 \\
\hline $1 \mathrm{H}-1,59$ & 0.59 & 0.594 & $2 \mathrm{H}-7,15$ & 13.05 & 0.964 & $3 \mathrm{H}-6,78$ & 21.68 & 1.310 & $5 X-3,125$ & 34.57 & 0.909 \\
\hline $1 \mathrm{H}-1,62$ & 0.62 & 0.632 & $2 \mathrm{H}-7,28$ & 13.18 & 0.989 & $3 \mathrm{H}-6,93$ & 21.83 & 1.349 & $5 X-4,6$ & 34.71 & 1.095 \\
\hline $1 \mathrm{H}-1,68$ & 0.68 & 0.594 & $2 \mathrm{H}-7,42$ & 13.32 & 1.023 & $3 \mathrm{H}-6,103$ & 21.93 & 0.928 & $5 X-4,16$ & 34.81 & 0.997 \\
\hline $1 \mathrm{H}-1,78$ & 0.78 & 0.555 & $2 \mathrm{H}-7,52$ & 13.42 & 0.870 & $3 \mathrm{H}-6,116$ & 22.06 & 0.929 & $5 X-4,26$ & 34.91 & 0.934 \\
\hline $1 \mathrm{H}-1,88$ & 0.88 & 0.493 & $3 \mathrm{H}-1,6$ & 13.46 & 1.105 & $4 \mathrm{H}-1,4$ & 22.94 & 0.777 & $5 X-4,36$ & 35.01 & 0.930 \\
\hline $1 \mathrm{H}-1,98$ & 0.98 & 0.640 & $3 \mathrm{H}-1,14$ & 13.54 & 0.839 & $4 \mathrm{H}-1,13$ & 23.03 & 0.944 & $5 X-4,46$ & 35.11 & 0.884 \\
\hline $1 \mathrm{H}-1,108$ & 1.08 & 0.545 & $3 \mathrm{H}-1,39$ & 13.79 & 0.946 & $4 \mathrm{H}-1,23$ & 23.13 & 1.446 & $5 X-4,53$ & 35.18 & 1.022 \\
\hline $1 \mathrm{H}-1,118$ & 1.18 & 0.619 & $3 \mathrm{H}-1,45$ & 13.85 & 0.777 & $4 \mathrm{H}-1,48$ & 23.38 & 0.978 & $5 X-4,68$ & 35.33 & 0.978 \\
\hline $1 \mathrm{H}-1,128$ & 1.28 & 0.562 & $3 \mathrm{H}-1,55$ & 13.95 & 0.906 & $4 \mathrm{H}-1,58$ & 23.48 & 1.424 & $5 X-4,78$ & 35.43 & 0.888 \\
\hline $1 \mathrm{H}-1,138$ & 1.38 & 0.650 & $3 \mathrm{H}-1,62$ & 14.02 & 0.980 & $4 \mathrm{H}-1,76$ & 23.66 & 1.661 & $5 X-4,88$ & 35.53 & 0.873 \\
\hline 311-U1326C- & & & $3 \mathrm{H}-1,71$ & 14.11 & 0.977 & $4 \mathrm{H}-1,92$ & 23.82 & 0.959 & $5 X-4,109$ & 35.74 & 0.852 \\
\hline $1 \mathrm{H}-2,7$ & 1.57 & 0.476 & $3 \mathrm{H}-1,85$ & 14.25 & 0.807 & $4 \mathrm{H}-1,102$ & 23.92 & 0.990 & $5 X-4,123$ & 35.88 & 0.869 \\
\hline $1 \mathrm{H}-2,13$ & 1.63 & 0.492 & $3 \mathrm{H}-1,91$ & 14.31 & 1.009 & $4 \mathrm{H}-1,118$ & 24.08 & 1.583 & $5 X-4,136$ & 36.01 & 0.896 \\
\hline $1 \mathrm{H}-2,17$ & 1.67 & 0.618 & $3 \mathrm{H}-1,101$ & 14.41 & 1.003 & $4 \mathrm{H}-1,129$ & 24.19 & 1.124 & $6 \mathrm{X}-1,12$ & 40.12 & 0.780 \\
\hline $1 \mathrm{H}-2,23$ & 1.73 & 0.605 & $3 \mathrm{H}-1,113$ & 14.53 & 0.847 & $4 \mathrm{H}-1,138$ & 24.28 & 1.346 & $6 \mathrm{X}-1,26$ & 40.26 & 0.827 \\
\hline $1 \mathrm{H}-2,33$ & 1.83 & 0.482 & $3 \mathrm{H}-1,123$ & 14.63 & 0.993 & $4 \mathrm{H}-1,143$ & 24.33 & 1.098 & $6 \mathrm{X}-1,49$ & 40.49 & 0.855 \\
\hline $1 \mathrm{H}-2,43$ & 1.93 & 0.478 & $3 \mathrm{H}-1,136$ & 14.76 & 0.840 & $4 \mathrm{H}-3,7$ & 25.97 & 2.024 & $6 X-1,70$ & 40.70 & 0.872 \\
\hline $1 \mathrm{H}-2,53$ & 2.03 & 0.572 & $3 \mathrm{H}-1,146$ & 14.86 & 0.818 & $4 \mathrm{H}-3,8$ & 25.98 & 1.089 & $6 X-1,93$ & 40.93 & 1.066 \\
\hline $1 \mathrm{H}-2,63$ & 2.13 & 0.455 & $3 \mathrm{H}-2,6$ & 14.96 & 1.121 & $4 \mathrm{H}-3,17$ & 26.07 & 1.971 & $6 \mathrm{X}-1,108$ & 41.08 & 1.208 \\
\hline $2 \mathrm{H}-2,5$ & 5.45 & 0.891 & $3 \mathrm{H}-2,16$ & 15.06 & 0.835 & $4 \mathrm{H}-3,18$ & 26.08 & 1.829 & $6 X-1,118$ & 41.18 & 1.045 \\
\hline $2 \mathrm{H}-2,9$ & 5.49 & 0.638 & $3 \mathrm{H}-2,26$ & 15.16 & 0.837 & $4 \mathrm{H}-3,18$ & 26.08 & 1.025 & $6 X-1,131$ & 41.31 & 0.976 \\
\hline $2 \mathrm{H}-2,11$ & 5.51 & 1.125 & $3 \mathrm{H}-2,36$ & 15.26 & 0.780 & $4 \mathrm{H}-3,25$ & 26.15 & 1.990 & $6 X-1,144$ & 41.44 & 1.011 \\
\hline & 1.0. & 1.125 & $3 \mathrm{H}-2,46$ & 15.36 & 0.939 & $4 \mathrm{H}-3,28$ & 26.18 & 1.486 & $6 X-3,10$ & 43.10 & 1.079 \\
\hline Parallel & & & $3 \mathrm{H}-2,56$ & 15.46 & 0.926 & $4 \mathrm{H}-3,31$ & 26.21 & 2.183 & $6 X-3,20$ & 43.20 & 1.126 \\
\hline 311-U1326C- & & & $3 \mathrm{H}-2,66$ & 15.56 & 0.879 & $4 \mathrm{H}-3,32$ & 26.22 & 1.159 & $6 X-3,33$ & 43.33 & 1.095 \\
\hline $2 \mathrm{H}-2,14$ & 5.54 & 0.758 & $3 \mathrm{H}-2,76$ & 15.66 & 0.854 & $4 \mathrm{H}-3,39$ & 26.29 & 2.393 & $6 X-3,43$ & 43.43 & 1.067 \\
\hline $2 \mathrm{H}-2,17$ & 5.57 & 0.973 & $3 \mathrm{H}-2,86$ & 15.76 & 0.787 & $4 \mathrm{H}-3,39$ & 26.29 & 1.243 & $6 X-3,53$ & 43.53 & 0.951 \\
\hline $2 \mathrm{H}-2,21$ & 5.61 & 0.800 & $3 \mathrm{H}-2,96$ & 15.86 & 0.856 & $4 \mathrm{H}-3,47$ & 26.37 & 1.184 & $6 X-3,63$ & 43.63 & 1.217 \\
\hline $2 \mathrm{H}-2,26$ & 5.66 & 1.112 & $3 \mathrm{H}-2,105$ & 15.95 & 1.094 & $4 \mathrm{H}-3,48$ & 26.38 & 2.223 & $6 X-3,73$ & 43.73 & 0.799 \\
\hline $2 \mathrm{H}-2,38$ & 5.78 & 0.750 & $3 \mathrm{H}-3,4$ & 16.44 & 0.852 & $4 \mathrm{H}-3,58$ & 26.48 & 1.451 & $6 X-3,78$ & 43.78 & 0.893 \\
\hline $2 \mathrm{H}-2,50$ & 5.90 & 0.833 & $3 \mathrm{H}-3,14$ & 16.54 & 0.746 & $4 \mathrm{H}-3,59$ & 26.49 & 1.155 & $6 X-3,88$ & 43.88 & 0.892 \\
\hline $2 \mathrm{H}-2,61$ & 6.01 & 0.838 & $3 \mathrm{H}-3,24$ & 16.64 & 0.754 & $4 \mathrm{H}-3,69$ & 26.59 & 1.204 & $6 X-4,6$ & 44.08 & 1.071 \\
\hline $2 \mathrm{H}-4,4$ & 8.44 & 0.869 & $3 \mathrm{H}-3,34$ & 16.74 & 0.838 & $4 \mathrm{H}-3,70$ & 26.60 & 1.573 & $6 X-4,17$ & 44.19 & 0.869 \\
\hline $2 \mathrm{H}-4,8$ & 8.48 & 0.892 & $3 \mathrm{H}-3,42$ & 16.82 & 0.950 & $4 \mathrm{H}-3,73$ & 26.63 & 1.092 & $6 \mathrm{X}-4,29$ & 44.31 & 0.974 \\
\hline $2 \mathrm{H}-4,18$ & 8.58 & 0.582 & $3 \mathrm{H}-3,52$ & 16.92 & 0.837 & $4 \mathrm{H}-3,77$ & 26.67 & 1.974 & $6 X-4,39$ & 44.41 & 1.108 \\
\hline $2 \mathrm{H}-4,19$ & 8.59 & 0.869 & $3 \mathrm{H}-3,62$ & 17.02 & 0.916 & $4 \mathrm{H}-3,84$ & 26.74 & 1.144 & $6 X-4,44$ & 44.46 & 1.451 \\
\hline $2 \mathrm{H}-4,24$ & 8.64 & 0.760 & $3 \mathrm{H}-3,72$ & 17.12 & 1.016 & $4 \mathrm{H}-3,85$ & 26.75 & 1.568 & $6 X-4,50$ & 44.52 & 4.222 \\
\hline $2 \mathrm{H}-4,34$ & 8.74 & 0.874 & $3 \mathrm{H}-3,86$ & 17.26 & 0.782 & $4 \mathrm{H}-3,87$ & 26.77 & 1.242 & $6 X-4,60$ & 44.62 & 1.101 \\
\hline $2 \mathrm{H}-4,37$ & 8.77 & 0.960 & $3 \mathrm{H}-3,96$ & 17.36 & 0.909 & $4 \mathrm{H}-3,88$ & 26.78 & 1.265 & $6 X-4,66$ & 44.68 & 1.215 \\
\hline $2 \mathrm{H}-4,44$ & 8.84 & 0.968 & $3 \mathrm{H}-3,106$ & 17.46 & 0.857 & $4 \mathrm{H}-3,94$ & 26.84 & 1.238 & $6 X-4,72$ & 44.74 & 0.941 \\
\hline $2 \mathrm{H}-4,50$ & 8.90 & 0.881 & $3 \mathrm{H}-3,116$ & 17.56 & 0.919 & $4 \mathrm{H}-3,94$ & 26.84 & 1.168 & $6 X-5,3$ & 45.01 & 1.247 \\
\hline $2 \mathrm{H}-4,54$ & 8.94 & 0.960 & $3 \mathrm{H}-3,126$ & 17.66 & 0.953 & $4 \mathrm{H}-3,104$ & 26.94 & 1.179 & $6 x-5,6$ & 45.04 & 1.166 \\
\hline $2 \mathrm{H}-4,64$ & 9.04 & 0.851 & $3 \mathrm{H}-3,136$ & 17.76 & 0.890 & $4 \mathrm{H}-3,106$ & 26.96 & 1.146 & $6 X-5,13$ & 45.11 & 1.285 \\
\hline $2 \mathrm{H}-5,7$ & 9.97 & 0.845 & $3 \mathrm{H}-4,6$ & 17.96 & 0.796 & $4 \mathrm{H}-3,128$ & 27.18 & 1.196 & $6 X-5,25$ & 45.23 & 1.135 \\
\hline $2 \mathrm{H}-5,12$ & 10.02 & 0.888 & $3 \mathrm{H}-4,16$ & 18.06 & 0.805 & $4 \mathrm{H}-3,137$ & 27.27 & 1.288 & $6 X-5,40$ & 45.38 & 1.073 \\
\hline $2 \mathrm{H}-5,17$ & 10.07 & 1.004 & $3 \mathrm{H}-4,26$ & 18.16 & 0.768 & $4 \mathrm{H}-3,142$ & 27.32 & 1.495 & $6 X-5,54$ & 45.52 & 1.110 \\
\hline $2 \mathrm{H}-5,27$ & 10.17 & 0.985 & $3 \mathrm{H}-4,36$ & 18.26 & 0.793 & $4 \mathrm{H}-4,7$ & 27.47 & 1.242 & $6 X-5,67$ & 45.65 & 1.042 \\
\hline $2 \mathrm{H}-5,31$ & 10.21 & 0.943 & $3 \mathrm{H}-4,48$ & 18.38 & 0.852 & $4 \mathrm{H}-4,17$ & 27.57 & 1.169 & $6 X-5,70$ & 45.68 & 1.432 \\
\hline $2 \mathrm{H}-5,37$ & 10.27 & 0.817 & $3 \mathrm{H}-5,12$ & 19.52 & 0.833 & $5 X-1,5$ & 30.45 & 0.882 & $6 X-5,79$ & 45.77 & 1.050 \\
\hline $2 \mathrm{H}-5,43$ & 10.33 & 0.864 & $3 \mathrm{H}-5,26$ & 19.66 & 0.765 & $5 X-1,15$ & 30.55 & 0.761 & $7 X-2,16$ & 51.19 & 1.168 \\
\hline $2 \mathrm{H}-5,47$ & 10.37 & 0.889 & $3 \mathrm{H}-5,36$ & 19.76 & 0.788 & $5 X-1,25$ & 30.65 & 0.700 & $7 X-2,17$ & 51.20 & 0.985 \\
\hline $2 \mathrm{H}-5,57$ & 10.47 & 1.075 & $3 \mathrm{H}-5,46$ & 19.86 & 0.917 & $5 X-1,45$ & 30.85 & 0.822 & $7 X-2,27$ & 51.30 & 1.222 \\
\hline $2 \mathrm{H}-5,60$ & 10.50 & 1.114 & $3 \mathrm{H}-5,53$ & 19.93 & 0.781 & $5 X-1,55$ & 30.95 & 1.013 & $7 X-2,37$ & 51.40 & 1.035 \\
\hline $2 \mathrm{H}-5,67$ & 10.57 & 1.011 & $3 \mathrm{H}-5,63$ & 20.03 & 0.995 & $5 X-1,72$ & 31.12 & 1.038 & $7 X-2,47$ & 51.50 & 0.942 \\
\hline $2 \mathrm{H}-5,77$ & 10.67 & 1.143 & $3 \mathrm{H}-5,77$ & 20.17 & 0.949 & $5 X-1,82$ & 31.22 & 0.831 & $7 X-2,57$ & 51.60 & 0.999 \\
\hline $2 \mathrm{H}-5,84$ & 10.74 & 0.962 & $3 \mathrm{H}-5,87$ & 20.27 & 1.068 & $5 X-1,92$ & 31.32 & 0.710 & $7 X-2,62$ & 51.65 & 1.076 \\
\hline $2 \mathrm{H}-6,7$ & 11.47 & 1.177 & $3 \mathrm{H}-5,97$ & 20.37 & 0.873 & $5 X-1,105$ & 31.45 & 1.025 & $7 X-2,72$ & 51.75 & 1.091 \\
\hline $2 \mathrm{H}-6,12$ & 11.52 & 1.100 & $3 \mathrm{H}-5,128$ & 20.68 & 0.842 & $5 X-1,118$ & 31.58 & 0.895 & $7 X-2,85$ & 51.88 & 1.040 \\
\hline $2 \mathrm{H}-6,17$ & 11.57 & 1.043 & $3 \mathrm{H}-5,129$ & 20.69 & 1.655 & $5 X-1,130$ & 31.70 & 0.842 & $7 X-2,95$ & 51.98 & 1.059 \\
\hline
\end{tabular}


Table T14 (continued).

\begin{tabular}{|c|c|c|c|c|c|c|c|c|c|c|c|}
\hline $\begin{array}{l}\text { Core, section, } \\
\text { interval }(\mathrm{cm})\end{array}$ & $\begin{array}{l}\text { Depth } \\
\text { (mbsf) }\end{array}$ & $\begin{array}{l}\text { Resistivity } \\
(\Omega \mathrm{m})\end{array}$ & $\begin{array}{l}\text { Core, section, } \\
\text { interval }(\mathrm{cm})\end{array}$ & $\begin{array}{l}\text { Depth } \\
\text { (mbsf) }\end{array}$ & $\begin{array}{l}\text { Resistivity } \\
(\Omega \mathrm{m})\end{array}$ & $\begin{array}{l}\text { Core, section, } \\
\text { interval }(\mathrm{cm})\end{array}$ & $\begin{array}{l}\text { Depth } \\
\text { (mbsf) }\end{array}$ & $\begin{array}{l}\text { Resistivity } \\
(\Omega \mathrm{m})\end{array}$ & $\begin{array}{l}\text { Core, section, } \\
\text { interval }(\mathrm{cm})\end{array}$ & $\begin{array}{l}\text { Depth } \\
\text { (mbsf) }\end{array}$ & $\begin{array}{l}\text { Resistivity } \\
(\Omega \mathrm{m})\end{array}$ \\
\hline $7 X-2,105$ & 52.08 & 1.060 & $2 X-1,50$ & 88.90 & 1.084 & $3 X-3,54$ & 101.64 & 1.220 & $5 X-1,83$ & 118.13 & 1.158 \\
\hline $7 X-2,116$ & 52.19 & 1.048 & $2 X-1,60$ & 89.00 & 1.087 & $3 X-3,64$ & 101.74 & 1.324 & $5 X-1,103$ & 118.33 & 1.376 \\
\hline $7 X-2,126$ & 52.29 & 1.079 & $2 X-1,68$ & 89.08 & 0.814 & $3 X-3,74$ & 101.84 & 1.253 & $5 X-1,124$ & 118.54 & 1.151 \\
\hline $7 X-2,136$ & 52.39 & 1.135 & $2 X-1,121$ & 89.61 & 0.962 & $3 X-3,85$ & 101.95 & 1.162 & $5 X-2,15$ & 118.85 & 0.979 \\
\hline $7 X-2,146$ & 52.49 & 1.054 & $2 X-1,135$ & 89.75 & 1.232 & $3 X-3,95$ & 102.05 & 1.282 & $5 X-2,33$ & 119.03 & 1.612 \\
\hline $7 X-3,4$ & 52.57 & 1.075 & $2 X-1,145$ & 89.85 & 1.164 & $3 X-3,105$ & 102.15 & 1.549 & $5 X-2,55$ & 119.25 & 0.992 \\
\hline $7 X-3,22$ & 52.75 & 0.952 & $2 X-1,147$ & 89.87 & 1.047 & $3 X-3,115$ & 102.25 & 1.361 & $5 X-2,75$ & 119.45 & 1.078 \\
\hline $7 X-3,37$ & 52.90 & 0.972 & $2 X-1,149$ & 89.89 & 0.886 & $3 X-3,125$ & 102.35 & 1.630 & $5 X-2,97$ & 119.67 & 0.947 \\
\hline $7 X-3,52$ & 53.05 & 1.049 & $2 X-3,9$ & 91.49 & 1.172 & $3 X-3,140$ & 102.50 & 1.426 & $5 X-2,126$ & 119.96 & 1.124 \\
\hline $7 X-3,61$ & 53.14 & 1.232 & $2 X-3,19$ & 91.59 & 0.999 & $3 X-4,6$ & 102.66 & 1.374 & $5 X-4,12$ & 121.66 & 1.145 \\
\hline $7 X-3,71$ & 53.24 & 1.344 & $2 X-3,29$ & 91.69 & 1.078 & $3 X-4,16$ & 102.76 & 1.342 & $5 X-4,26$ & 121.80 & 1.420 \\
\hline $7 X-4,3$ & 53.57 & 0.972 & $2 X-3,39$ & 91.79 & 0.928 & $3 X-4,26$ & 102.86 & 1.241 & $5 X-4,46$ & 122.00 & 0.950 \\
\hline $7 X-4,13$ & 53.67 & 0.241 & $2 X-3,49$ & 91.89 & 1.109 & $3 X-4,36$ & 102.96 & 1.706 & $5 X-4,66$ & 122.20 & 0.990 \\
\hline $8 X-1,5$ & 59.45 & 0.528 & $2 X-3,59$ & 91.99 & 1.040 & $3 X-4,46$ & 103.06 & 1.446 & $5 X-4,86$ & 122.40 & 0.986 \\
\hline $8 X-1,15$ & 59.55 & 0.470 & $2 X-3,69$ & 92.09 & 1.056 & $3 X-4,56$ & 103.16 & 1.478 & $5 X-4,106$ & 122.60 & 1.408 \\
\hline $8 X-1,25$ & 59.65 & 46.962 & $2 X-3,83$ & 92.23 & 1.111 & $3 X-5,10$ & 103.89 & 1.475 & $5 X-5,5$ & 123.09 & 1.310 \\
\hline $8 X-1,35$ & 59.75 & 0.615 & $2 X-3,96$ & 92.36 & 0.991 & $3 X-5,20$ & 103.99 & 1.884 & $5 X-5,25$ & 123.29 & 1.564 \\
\hline $8 X-1,45$ & 59.85 & 0.657 & $2 X-3,106$ & 92.46 & 1.122 & $3 x-5,30$ & 104.09 & 1.583 & $5 X-6,10$ & 123.70 & 1.182 \\
\hline $8 X-1,55$ & 59.95 & 0.579 & $2 X-3,117$ & 92.57 & 1.023 & $3 X-5,40$ & 104.19 & 1.708 & $5 X-6,30$ & 123.90 & 1.438 \\
\hline $8 X-1,65$ & 60.05 & 0.623 & $2 X-3,136$ & 92.76 & 1.121 & $3 X-5,50$ & 104.29 & 1.448 & $5 X-6,50$ & 124.10 & 1.928 \\
\hline $8 X-1,75$ & 60.15 & 0.641 & $2 X-3,142$ & 92.82 & 0.906 & $3 X-5,62$ & 104.41 & 1.804 & $5 X-6,73$ & 124.33 & 1.671 \\
\hline $8 X-1,85$ & 60.25 & 0.728 & $2 X-4,5$ & 92.95 & 1.116 & $4 X-1,11$ & 107.81 & 1.042 & $6 X-1,10$ & 127.10 & 0.885 \\
\hline $9 X-2,33$ & 70.93 & 0.837 & $2 X-4,26$ & 93.16 & 0.852 & $4 X-1,21$ & 107.91 & 0.831 & $6 X-1,30$ & 127.30 & 0.679 \\
\hline $9 X-2,43$ & 71.03 & 0.812 & $2 X-4,41$ & 93.31 & 1.060 & $4 X-1,31$ & 108.01 & 1.018 & $6 X-1,50$ & 127.50 & 0.714 \\
\hline $9 X-2,53$ & 71.13 & 0.673 & $2 X-4,49$ & 93.39 & 0.714 & $4 X-1,41$ & 108.11 & 0.702 & $6 X-1,70$ & 127.70 & 0.740 \\
\hline $9 X-2,63$ & 71.23 & 0.710 & $2 X-4,57$ & 93.47 & 0.920 & $4 X-1,51$ & 108.21 & 0.984 & $6 X-1,90$ & 127.90 & 0.922 \\
\hline $9 X-2,73$ & 71.33 & 0.689 & $2 X-4,78$ & 93.68 & 0.901 & $4 X-1,61$ & 108.31 & 0.794 & $6 X-1,110$ & 128.10 & 1.714 \\
\hline $9 X-2,79$ & 71.39 & 1.130 & $2 X-4,90$ & 93.80 & 1.046 & $4 X-1,71$ & 108.41 & 0.909 & $6 X-3,10$ & 130.10 & 0.692 \\
\hline $9 X-2,89$ & 71.49 & 1.025 & $2 X-4,107$ & 93.97 & 1.018 & $4 X-1,81$ & 108.51 & 0.933 & $6 X-3,30$ & 130.30 & 0.702 \\
\hline $9 X-2,95$ & 71.55 & 0.814 & $2 X-4,116$ & 94.06 & 0.926 & $4 X-1,91$ & 108.61 & 0.832 & $6 X-3,50$ & 130.50 & 1.063 \\
\hline $9 X-2,99$ & 71.59 & 1.172 & $2 X-4,127$ & 94.17 & 0.932 & $4 X-1,102$ & 108.72 & 1.068 & $6 X-3,70$ & 130.70 & 0.811 \\
\hline $9 X-2,109$ & 71.69 & 1.120 & $2 X-4,136$ & 94.26 & 1.218 & $4 X-1,112$ & 108.82 & 1.017 & $6 X-3,90$ & 130.90 & 0.794 \\
\hline $9 X-2,119$ & 71.79 & 0.680 & $2 X-4,146$ & 94.36 & 1.009 & $4 X-1,122$ & 108.92 & 0.831 & $6 X-4,9$ & 131.22 & 0.918 \\
\hline $9 X-2,129$ & 71.89 & 0.802 & $2 X-5,4$ & 94.44 & 1.034 & $4 X-1,132$ & 109.02 & 0.830 & $6 X-4,29$ & 131.42 & 0.898 \\
\hline $9 X-2,139$ & 71.99 & 0.769 & $2 X-5,16$ & 94.56 & 1.032 & $4 X-1,142$ & 109.12 & 0.689 & $6 X-4,49$ & 131.62 & 0.963 \\
\hline $9 X-3,5$ & 72.15 & 1.001 & $2 X-5,25$ & 94.65 & 0.954 & $4 X-3,6$ & 110.76 & 1.142 & $6 X-4,71$ & 131.84 & 0.884 \\
\hline $9 X-3,15$ & 72.25 & 0.710 & $2 X-5,32$ & 94.72 & 1.105 & $4 X-3,20$ & 110.90 & 0.980 & $6 X-4,83$ & 131.96 & 0.948 \\
\hline $9 X-3,25$ & 72.35 & 0.647 & $2 X-5,42$ & 94.82 & 1.035 & $4 X-3,30$ & 111.00 & 1.224 & $6 X-5,8$ & 132.53 & 1.374 \\
\hline $9 X-3,35$ & 72.45 & 0.795 & $2 X-5,58$ & 94.98 & 0.809 & $4 X-3,40$ & 111.10 & 1.169 & $6 X-5,28$ & 132.73 & 0.963 \\
\hline $9 X-3,45$ & 72.55 & 0.726 & $2 X-5,71$ & 95.11 & 1.126 & $4 X-4,6$ & 111.82 & 1.014 & $6 X-5,48$ & 132.93 & 1.187 \\
\hline $9 X-3,55$ & 72.65 & 0.737 & $2 X-5,82$ & 95.22 & 1.201 & $4 X-4,21$ & 111.97 & 0.896 & $6 X-5,68$ & 133.13 & 1.319 \\
\hline $9 X-3,63$ & 72.73 & 0.904 & $2 X-5,92$ & 95.32 & 0.908 & $4 X-4,31$ & 112.07 & 1.224 & $6 X-5,88$ & 133.33 & 0.948 \\
\hline $9 X-4,10$ & 73.26 & 0.819 & $2 X-6,20$ & 96.04 & 0.865 & $4 X-4,41$ & 112.17 & 1.175 & $6 X-6,11$ & 133.56 & 0.934 \\
\hline $9 X-4,20$ & 73.36 & 0.926 & $2 X-6,30$ & 96.14 & 1.061 & $4 X-4,55$ & 112.31 & 1.158 & $6 X-6,31$ & 133.76 & 0.904 \\
\hline $9 X-4,30$ & 73.46 & 0.760 & $2 X-6,38$ & 96.22 & 1.160 & $4 X-4,65$ & 112.41 & 1.072 & $6 X-6,55$ & 134.00 & 1.067 \\
\hline $9 X-4,40$ & 73.56 & 0.882 & $2 X-6,48$ & 96.32 & 1.191 & $4 X-4,74$ & 112.50 & 1.041 & $6 X-6,79$ & 134.24 & 0.883 \\
\hline $9 X-4,50$ & 73.66 & 0.928 & $2 X-6,58$ & 96.42 & 1.037 & $4 X-4,84$ & 112.60 & 1.041 & $7 X-1,8$ & 136.68 & 0.754 \\
\hline $9 X-4,60$ & 73.76 & 1.274 & $2 X-6,68$ & 96.52 & 1.068 & $4 X-4,94$ & 112.70 & 0.889 & $7 X-1,28$ & 136.88 & 0.738 \\
\hline $9 X-4,65$ & 73.81 & 1.007 & $2 X-6,84$ & 96.68 & 1.104 & $4 X-4,98$ & 112.74 & 1.157 & $7 X-1,48$ & 137.08 & 0.683 \\
\hline $9 X-4,80$ & 73.96 & 0.967 & $2 X-6,89$ & 96.73 & 1.064 & $4 X-4,108$ & 112.84 & 1.073 & $7 X-1,68$ & 137.28 & 0.903 \\
\hline $9 X-4,90$ & 74.06 & 0.910 & $3 X-1,6$ & 98.16 & 0.775 & $4 X-4,118$ & 112.94 & 1.000 & $7 X-2,9$ & 137.65 & 0.770 \\
\hline $9 X-4,100$ & 74.16 & 1.143 & $3 X-1,21$ & 98.31 & 0.825 & $4 X-4,130$ & 113.06 & 1.037 & $7 X-2,10$ & 137.66 & 0.939 \\
\hline $10 X-1,10$ & 78.80 & 0.581 & $3 X-1,30$ & 98.40 & 0.846 & $4 X-5,6$ & 113.17 & 0.990 & $7 X-2,29$ & 137.85 & 0.747 \\
\hline $10 X-1,20$ & 78.90 & 0.714 & $3 x-1,36$ & 98.46 & 1.066 & $4 X-5,16$ & 113.27 & 1.103 & $7 X-2,49$ & 138.05 & 0.717 \\
\hline $10 X-1,30$ & 79.00 & 0.773 & $3 X-1,46$ & 98.56 & 0.994 & $4 X-5,26$ & 113.37 & 1.125 & $7 X-2,69$ & 138.25 & 0.816 \\
\hline $10 X-1,40$ & 79.10 & 0.668 & $3 X-1,56$ & 98.66 & 1.029 & $4 X-5,36$ & 113.47 & 1.173 & $7 X-2,89$ & 138.45 & 1.046 \\
\hline $10 X-1,45$ & 79.15 & 0.765 & $3 X-1,65$ & 98.75 & 0.973 & $4 X-5,46$ & 113.57 & 1.286 & $7 X-4,30$ & 140.49 & 0.788 \\
\hline $10 X-1,55$ & 79.25 & 0.607 & $3 X-1,75$ & 98.85 & 0.997 & $4 X-5,56$ & 113.67 & 1.312 & $7 X-4,50$ & 140.69 & 0.839 \\
\hline $10 X-1,65$ & 79.35 & 0.666 & $3 X-1,80$ & 98.90 & 1.101 & $4 X-5,66$ & 113.77 & 1.198 & $7 X-4,70$ & 140.89 & 1.093 \\
\hline $10 X-1,75$ & 79.45 & 0.806 & $3 X-1,90$ & 99.00 & 1.010 & $4 X-5,73$ & 113.84 & 1.291 & $7 X-4,92$ & 141.11 & 0.893 \\
\hline $10 X-1,85$ & 79.55 & 0.667 & $3 X-1,98$ & 99.08 & 0.960 & $4 X-5,83$ & 113.94 & 1.323 & $7 X-4,112$ & 141.31 & 0.964 \\
\hline $10 X-1,95$ & 79.65 & 0.725 & $3 X-1,108$ & 99.18 & 1.047 & $4 X-5,105$ & 114.16 & 1.056 & $7 X-4,132$ & 141.51 & 1.166 \\
\hline $10 X-1,105$ & 79.75 & 1.622 & $3 X-1,118$ & 99.28 & 0.911 & $4 X-6,17$ & 114.74 & 1.027 & $8 X-1,13$ & 146.43 & 0.882 \\
\hline $10 X-1,115$ & 79.85 & 0.739 & $3 X-1,127$ & 99.37 & 0.913 & $4 X-6,24$ & 114.81 & 1.190 & $8 X-1,29$ & 146.59 & 0.557 \\
\hline $10 X-1,130$ & 80.00 & 0.679 & $3 X-3,14$ & 101.24 & 1.470 & $4 X-6,32$ & 114.89 & 1.320 & $8 X-3,15$ & 148.91 & 0.657 \\
\hline $10 X-1,140$ & 80.10 & 0.821 & $3 X-3,24$ & 101.34 & 1.431 & $5 X-1,6$ & 117.36 & 0.966 & $8 X-3,35$ & 149.11 & 1.238 \\
\hline \multirow{2}{*}{$\begin{array}{c}\text { 311-U1326D- } \\
2 X-1,40\end{array}$} & & & $3 X-3,34$ & 101.44 & 1.506 & $5 X-1,32$ & 117.62 & 0.948 & $8 X-3,49$ & 149.25 & 0.661 \\
\hline & 88.80 & 1.129 & $3 X-3,44$ & 101.54 & 1.179 & $5 X-1,54$ & 117.84 & 0.965 & $8 X-3,55$ & 149.31 & 1.720 \\
\hline
\end{tabular}


Table T14 (continued).

\begin{tabular}{|c|c|c|c|c|c|c|c|c|c|c|c|}
\hline $\begin{array}{l}\text { Core, section, } \\
\text { interval }(\mathrm{cm})\end{array}$ & $\begin{array}{l}\text { Depth } \\
\text { (mbsf) }\end{array}$ & $\begin{array}{l}\text { Resistivity } \\
(\Omega \mathrm{m})\end{array}$ & $\begin{array}{l}\text { Core, section, } \\
\text { interval }(\mathrm{cm})\end{array}$ & $\begin{array}{l}\text { Depth } \\
\text { (mbsf) }\end{array}$ & $\begin{array}{l}\text { Resistivity } \\
(\Omega \mathrm{m})\end{array}$ & $\begin{array}{l}\text { Core, section, } \\
\text { interval }(\mathrm{cm})\end{array}$ & $\begin{array}{l}\text { Depth } \\
\text { (mbsf) }\end{array}$ & $\begin{array}{l}\text { Resistivity } \\
(\Omega \mathrm{m})\end{array}$ & $\begin{array}{l}\text { Core, section, } \\
\text { interval }(\mathrm{cm})\end{array}$ & $\begin{array}{l}\text { Depth } \\
\text { (mbsf) }\end{array}$ & $\begin{array}{c}\text { Resistivity } \\
(\Omega \mathrm{m})\end{array}$ \\
\hline $8 X-3,75$ & 149.51 & 2.158 & $11 X-5,53$ & 180.72 & 1.428 & $14 X-6,4$ & 209.54 & 2.347 & $17 X-1,38$ & 233.28 & 0.624 \\
\hline $8 X-3,95$ & 149.71 & 0.830 & $11 x-5,66$ & 180.85 & 1.701 & $14 X-6,10$ & 209.60 & 3.881 & $17 X-1,48$ & 233.38 & 0.662 \\
\hline $8 X-3,98$ & 149.74 & 0.824 & $11 X-5,86$ & 181.05 & 1.214 & $14 X-6,43$ & 209.93 & 2.078 & $17 X-1,68$ & 233.58 & 1.086 \\
\hline $8 X-3,118$ & 149.94 & 0.871 & $11 X-5,110$ & 181.29 & 0.904 & $14 X-6,53$ & 210.03 & 1.012 & $17 X-1,88$ & 233.78 & 0.816 \\
\hline $8 X-3,133$ & 150.09 & 0.944 & $12 X-1,6$ & 184.86 & 0.744 & $15 X-1,20$ & 213.80 & 1.060 & $17 X-1,108$ & 233.98 & 1.257 \\
\hline $8 X-4,6$ & 150.20 & 1.952 & $12 X-1,16$ & 184.96 & 0.813 & $15 X-1,30$ & 213.90 & 0.944 & $17 X-1,136$ & 234.26 & 0.829 \\
\hline $8 X-4,13$ & 150.27 & 1.454 & $12 X-1,37$ & 185.17 & 0.866 & $15 X-1,40$ & 214.00 & 1.062 & $17 X-3,108$ & 236.98 & 0.965 \\
\hline $8 X-4,23$ & 150.37 & 0.952 & $12 X-1,47$ & 185.27 & 0.945 & $15 X-1,76$ & 214.36 & 1.006 & $17 X-3,118$ & 237.08 & 1.170 \\
\hline $8 x-4,32$ & 150.46 & 1.277 & $12 X-1,65$ & 185.45 & 1.003 & $15 X-1,91$ & 214.51 & 1.088 & $17 X-3,130$ & 237.20 & 1.249 \\
\hline $9 X-1,7$ & 155.97 & 0.558 & $12 X-2,10$ & 186.15 & 0.768 & $15 X-1,114$ & 214.74 & 0.938 & $17 X-3,146$ & 237.36 & 1.011 \\
\hline $9 X-1,31$ & 156.21 & 0.911 & $12 X-2,20$ & 186.25 & 0.953 & $15 X-1,129$ & 214.89 & 1.101 & $17 X-4,8$ & 237.48 & 1.404 \\
\hline $9 X-1,51$ & 156.41 & 0.579 & $12 X-2,30$ & 186.35 & 0.823 & $15 X-2,6$ & 215.08 & 1.393 & $17 X-4,28$ & 237.68 & 0.781 \\
\hline $9 X-1,74$ & 156.64 & 0.672 & $12 X-2,45$ & 186.50 & 0.916 & $15 X-2,21$ & 215.23 & 0.991 & $17 X-4,48$ & 237.88 & 0.893 \\
\hline $9 X-2,10$ & 157.34 & 0.782 & $12 X-2,58$ & 186.63 & 0.782 & $15 X-2,42$ & 215.44 & 1.235 & $17 X-4,56$ & 237.96 & 1.016 \\
\hline $9 X-2,30$ & 157.54 & 1.031 & $12 X-2,75$ & 186.80 & 0.844 & $15 X-2,52$ & 215.54 & 19.786 & $17 X-4,74$ & 238.14 & 0.794 \\
\hline $9 X-2,33$ & 157.57 & 1.161 & $12 X-2,97$ & 187.02 & 0.946 & $15 X-2,62$ & 215.64 & 1.020 & $17 X-4,100$ & 238.40 & 0.997 \\
\hline $9 X-2,44$ & 157.68 & 1.015 & $12 X-2,110$ & 187.15 & 1.029 & $15 X-2,93$ & 215.95 & 0.909 & $17 X-4,112$ & 238.52 & 1.175 \\
\hline $9 X-3,8$ & 157.79 & 0.718 & $12 X-2,133$ & 187.38 & 1.061 & $15 X-2,107$ & 216.09 & 1.079 & $17 X-4,127$ & 238.67 & 1.130 \\
\hline $9 X-3,12$ & 157.83 & 3.236 & $12 X-2,146$ & 187.51 & 1.064 & $15 X-2,115$ & 216.17 & 1.207 & $17 X-5,9$ & 238.99 & 1.400 \\
\hline $9 X-4,7$ & 158.18 & 1.085 & $12 X-4,6$ & 189.11 & 1.042 & $15 X-2,124$ & 216.26 & 1.064 & $17 X-5,16$ & 239.06 & 1.264 \\
\hline $9 X-4,17$ & 158.28 & 1.136 & $12 X-4,16$ & 189.21 & 0.989 & $15 X-2,131$ & 216.33 & 1.050 & $17 X-5,30$ & 239.20 & 1.036 \\
\hline $9 X-4,30$ & 158.41 & 1.391 & $12 X-4,26$ & 189.31 & 1.027 & $15 X-3,6$ & 216.42 & 1.028 & $17 X-5,42$ & 239.32 & 0.918 \\
\hline $10 \times-1,49$ & 166.09 & 0.769 & $12 X-4,38$ & 189.43 & 1.314 & $15 X-3,20$ & 216.56 & 1.037 & $17 X-5,53$ & 239.43 & 1.095 \\
\hline $10 x-1,65$ & 166.25 & 0.942 & $12 X-4,48$ & 189.53 & 1.580 & $15 X-3,36$ & 216.72 & 1.033 & $17 X-5,76$ & 239.66 & 1.534 \\
\hline $10 X-1,85$ & 166.45 & 0.943 & $12 X-4,64$ & 189.69 & 1.180 & $15 X-3,46$ & 216.82 & 1.159 & $17 X-5,96$ & 239.86 & 1.240 \\
\hline $10 X-1,105$ & 166.65 & 0.991 & $12 X-5,23$ & 189.95 & 1.475 & $15 X-3,65$ & 217.01 & 1.687 & $17 X-5,116$ & 240.06 & 0.666 \\
\hline $10 X-1,125$ & 166.85 & 0.927 & $12 X-5,38$ & 190.10 & 1.406 & $15 X-3,79$ & 217.15 & 2.322 & $17 X-5,126$ & 240.16 & 0.770 \\
\hline $10 X-2,17$ & 167.27 & 0.989 & $12 X-5,58$ & 190.30 & 1.390 & $15 X-3,89$ & 217.25 & 1.198 & $17 X-5,140$ & 240.30 & 0.736 \\
\hline $10 x-2,37$ & 167.47 & 0.729 & $12 X-5,70$ & 190.42 & 1.583 & $15 X-5,8$ & 219.44 & 0.990 & $17 X-6,14$ & 240.48 & 1.097 \\
\hline $10 x-2,56$ & 167.66 & 1.098 & $13 X-1,37$ & 194.77 & 0.832 & $15 X-5,18$ & 219.54 & 1.087 & $17 X-6,28$ & 240.62 & 1.247 \\
\hline $10 X-2,68$ & 167.78 & 1.157 & $13 X-1,70$ & 195.10 & 0.785 & $15 X-5,28$ & 219.64 & 1.013 & $17 X-6,37$ & 240.71 & 1.105 \\
\hline $10 X-2,88$ & 167.98 & 0.990 & $13 X-1,90$ & 195.30 & 1.055 & $15 X-5,38$ & 219.74 & 0.978 & $17 X-6,52$ & 240.86 & 0.968 \\
\hline $10 X-3,6$ & 168.58 & 0.946 & $13 X-3,11$ & 197.11 & 0.978 & $15 X-5,43$ & 219.79 & 1.239 & $18 X-2,7$ & 243.72 & 0.875 \\
\hline $10 x-3,16$ & 168.68 & 1.001 & $13 X-3,21$ & 197.21 & 1.331 & $15 X-6,7$ & 220.43 & 1.988 & $18 X-2,30$ & 243.95 & 0.979 \\
\hline $10 x-3,26$ & 168.78 & 0.842 & $13 X-3,31$ & 197.31 & 1.194 & $15 X-6,17$ & 220.53 & 1.178 & $18 X-2,57$ & 244.22 & 0.616 \\
\hline $10 x-3,36$ & 168.88 & 1.134 & $13 X-3,41$ & 197.41 & 0.868 & $15 X-6,27$ & 220.63 & 1.506 & $18 X-2,80$ & 244.45 & 1.076 \\
\hline $10 X-3,52$ & 169.04 & 0.684 & $13 X-3,51$ & 197.51 & 1.055 & $15 X-6,37$ & 220.73 & 1.386 & $20 X-1,4$ & 261.84 & 0.488 \\
\hline $10 x-3,62$ & 169.14 & 0.776 & $13 X-3,90$ & 197.90 & 1.126 & $15 X-6,47$ & 220.83 & 2.083 & $20 X-1,42$ & 262.22 & 0.801 \\
\hline $10 x-3,116$ & 169.68 & 1.128 & $13 X-4,4$ & 198.04 & 0.963 & $16 X-1,10$ & 223.40 & 1.338 & $20 X-1,54$ & 262.34 & 1.936 \\
\hline $10 X-3,126$ & 169.78 & 1.047 & $13 X-4,15$ & 198.15 & 0.968 & $16 X-1,37$ & 223.67 & 1.002 & $20 x-3,10$ & 263.85 & 1.083 \\
\hline $10 X-4,13$ & 170.15 & 1.215 & $13 X-4,25$ & 198.25 & 1.351 & $16 X-1,54$ & 223.84 & 0.921 & $20 x-3,30$ & 264.05 & 1.140 \\
\hline $10 X-4,26$ & 170.28 & 1.715 & $13 x-4,33$ & 198.33 & 1.142 & $16 X-1,78$ & 224.08 & 1.291 & $20 x-3,50$ & 264.25 & 1.575 \\
\hline $10 X-4,41$ & 170.43 & 1.205 & $13 X-4,44$ & 198.44 & 1.006 & $16 X-1,88$ & 224.18 & 2.544 & $20 x-3,70$ & 264.45 & 1.107 \\
\hline $10 X-4,55$ & 170.57 & 1.343 & $13 X-4,54$ & 198.54 & 1.363 & 16X-1, 111 & 224.41 & 1.697 & $20 X-3,90$ & 264.65 & 0.905 \\
\hline $10 x-4,67$ & 170.69 & 1.694 & $14 X-1,37$ & 204.37 & 0.799 & $16 X-1,130$ & 224.60 & 1.383 & $20 X-3,110$ & 264.85 & 1.299 \\
\hline $10 \times-4,77$ & 170.79 & 1.481 & $14 X-1,47$ & 204.47 & 1.000 & $16 X-2,42$ & 225.22 & 2.879 & $20 x-3,123$ & 264.98 & 1.195 \\
\hline $10 X-4,87$ & 170.89 & 1.416 & $14 X-1,57$ & 204.57 & 1.019 & $16 X-2,58$ & 225.38 & 1.664 & $20 X-4,6$ & 265.10 & 0.748 \\
\hline $11 X-1,9$ & 175.29 & 0.767 & 14X-1, 101 & 205.01 & 0.924 & $16 X-2,78$ & 225.58 & 1.856 & $20 X-4,26$ & 265.30 & 0.908 \\
\hline $11 X-1,19$ & 175.39 & 0.938 & $14 X-3,9$ & 206.36 & 0.926 & $16 \mathrm{X}-2,92$ & 225.72 & 1.153 & $20 \times-4,42$ & 265.46 & 0.943 \\
\hline $11 X-2,5$ & 175.74 & 0.631 & $14 X-3,19$ & 206.46 & 0.742 & $16 X-2,119$ & 225.99 & 0.783 & $20 X-5,8$ & 266.62 & 0.744 \\
\hline $11 X-2,25$ & 175.94 & 0.597 & $14 X-3,39$ & 206.66 & 0.920 & $16 X-4,8$ & 227.88 & 1.587 & $20 X-5,28$ & 266.82 & 1.238 \\
\hline $11 X-2,50$ & 176.19 & 0.829 & $14 X-3,49$ & 206.76 & 0.889 & $16 X-4,23$ & 228.03 & 0.752 & $20 \times-5,48$ & 267.02 & 1.764 \\
\hline $11 X-2,67$ & 176.36 & 1.519 & $14 X-4,11$ & 207.11 & 0.930 & $16 X-4,57$ & 228.37 & 0.785 & $20 \times-5,72$ & 267.26 & 0.907 \\
\hline $11 X-2,77$ & 176.46 & 1.504 & $14 X-4,22$ & 207.22 & 1.394 & $16 X-4,74$ & 228.54 & 1.147 & $20 X-5,85$ & 267.39 & 1.350 \\
\hline $11 X-2,87$ & 176.56 & 0.972 & $14 X-4,32$ & 207.32 & 1.045 & $16 X-4,90$ & 228.70 & 1.008 & $20 X-5,111$ & 267.65 & 1.778 \\
\hline $11 X-2,118$ & 176.87 & 1.259 & $14 X-4,42$ & 207.42 & 1.301 & $16 X-4,107$ & 228.87 & 1.078 & $20 X-5,131$ & 267.85 & 1.258 \\
\hline $11 X-4,8$ & 178.77 & 2.070 & $14 X-4,62$ & 207.62 & 0.946 & $16 X-5,63$ & 229.53 & 1.208 & $20 X-7,9$ & 269.13 & 0.344 \\
\hline $11 X-4,18$ & 178.87 & 1.626 & $14 X-4,111$ & 208.11 & 1.045 & $16 X-5,73$ & 229.63 & 1.000 & $20 x-7,13$ & 269.17 & 0.788 \\
\hline $11 X-4,25$ & 178.94 & 1.363 & $14 X-4,121$ & 208.21 & 1.366 & $16 X-5,83$ & 229.73 & 1.166 & $20 x-7,33$ & 269.37 & 0.790 \\
\hline $11 X-4,48$ & 179.17 & 0.888 & $14 X-4,134$ & 208.34 & 1.620 & $16 X-5,97$ & 229.87 & 1.035 & $20 x-7,33$ & 269.37 & 1.222 \\
\hline $11 X-4,74$ & 179.43 & 1.218 & $14 X-5,71$ & 209.21 & 1.785 & $16 X-5,109$ & 229.99 & 1.476 & $20 x-7,53$ & 269.57 & 1.138 \\
\hline $11 X-4,93$ & 179.62 & 0.776 & $14 X-5,81$ & 209.31 & 1.302 & $17 X-1,8$ & 232.98 & 0.638 & $20 x-7,71$ & 269.75 & 1.163 \\
\hline $11 X-5,12$ & 180.31 & 0.890 & $14 X-5,93$ & 209.43 & 1.057 & $17 X-1,18$ & 233.08 & 0.736 & $20 X-7,81$ & 269.85 & 1.113 \\
\hline $11 X-5,23$ & 180.42 & 1.151 & $14 X-5,99$ & 209.49 & 1.508 & $17 X-1,28$ & 233.18 & 0.484 & $20 X-7,102$ & 270.06 & 1.242 \\
\hline
\end{tabular}


Table T15. Thermal conductivity, Holes U1326B, U1326C, and U1326D.

\begin{tabular}{|c|c|c|c|c|c|}
\hline \multirow{2}{*}{$\begin{array}{l}\text { Core, section, } \\
\text { interval }(\mathrm{cm})\end{array}$} & \multirow{2}{*}{$\begin{array}{l}\text { Depth } \\
\text { (mbsf) }\end{array}$} & \multicolumn{4}{|c|}{ Thermal conductivity $(\mathrm{W} /[\mathrm{m} \cdot \mathrm{K}])$} \\
\hline & & Average & 1 & 2 & 3 \\
\hline \multicolumn{6}{|l|}{ 311-U1326B- } \\
\hline $1 \mathrm{H}-1,68$ & 0.68 & 1.027 & 1.006 & 1.040 & 1.036 \\
\hline \multicolumn{6}{|l|}{ 311-U1326C- } \\
\hline $1 \mathrm{H}-2,37$ & 1.87 & 0.881 & 0.888 & 0.875 & 0.879 \\
\hline $2 \mathrm{H}-2,27$ & 5.67 & 1.134 & 1.145 & 1.148 & 1.108 \\
\hline $2 \mathrm{H}-4,42$ & 8.82 & 0.973 & 0.971 & 0.974 & 0.974 \\
\hline $2 \mathrm{H}-6,50$ & 11.90 & 0.986 & 0.984 & 0.986 & 0.987 \\
\hline $3 \mathrm{H}-2,26$ & 15.16 & 1.172 & 1.182 & 1.158 & 1.175 \\
\hline $3 \mathrm{H}-4,37$ & 18.27 & 1.198 & 1.194 & 1.200 & 1.201 \\
\hline $3 \mathrm{H}-6,72$ & 21.62 & 1.173 & 1.170 & 1.172 & 1.178 \\
\hline $4 \mathrm{H}-1,92$ & 23.82 & 1.226 & 1.227 & 1.231 & 1.219 \\
\hline $4 \mathrm{H}-3,104$ & 26.94 & 0.894 & 0.893 & 0.893 & 0.897 \\
\hline $5 X-1,29$ & 30.69 & 1.042 & 0.970 & 1.062 & 1.094 \\
\hline $6 X-1,73$ & 40.73 & 0.820 & 0.815 & 0.826 & 0.820 \\
\hline $6 x-3,30$ & 43.30 & 1.061 & 1.061 & 1.058 & 1.063 \\
\hline $7 X-3,11$ & 52.64 & 1.208 & 1.208 & 1.208 & 1.208 \\
\hline $8 X-1,25$ & 59.65 & 1.037 & 1.021 & 1.041 & 1.050 \\
\hline $9 X-2,53$ & 71.13 & 1.048 & 1.052 & 1.047 & 1.046 \\
\hline $9 X-2,66$ & 71.26 & 1.078 & 1.077 & 1.075 & 1.082 \\
\hline $10 X-1,53$ & 79.23 & 1.048 & 1.059 & 1.045 & 1.040 \\
\hline \multicolumn{6}{|l|}{ 311-U1326D- } \\
\hline $2 X-3,99$ & 92.39 & 0.965 & 0.963 & 0.967 & 0.966 \\
\hline $2 X-4,134$ & 94.24 & 1.259 & 1.253 & 1.252 & 1.273 \\
\hline $3 X-4,28$ & 102.88 & 0.965 & 0.967 & 0.965 & 0.964 \\
\hline $3 X-5,28$ & 104.07 & 0.960 & 0.962 & 0.959 & 0.959 \\
\hline $4 X-1,16$ & 107.86 & 0.971 & 0.991 & 0.962 & 0.960 \\
\hline $4 X-5,32$ & 113.43 & 1.305 & 1.295 & 1.314 & 1.307 \\
\hline $5 X-1,130$ & 118.60 & 1.014 & 1.010 & 1.017 & 1.016 \\
\hline $5 X-4,47$ & 122.01 & 0.903 & 0.908 & 0.903 & 0.898 \\
\hline $6 X-1,85$ & 127.85 & 1.218 & 1.219 & 1.218 & 1.217 \\
\hline $6 X-4,27$ & 131.40 & 1.122 & 1.122 & 1.121 & 1.122 \\
\hline $6 X-6,26$ & 133.71 & 1.151 & 1.150 & 1.151 & 1.153 \\
\hline $7 X-1,43$ & 137.03 & 0.779 & 0.796 & 0.789 & 0.751 \\
\hline $7 X-3,76$ & 139.50 & 1.325 & 1.310 & 1.332 & 1.333 \\
\hline $8 X-2,29$ & 148.09 & 1.130 & 1.128 & 1.130 & 1.133 \\
\hline $8 X-4,29$ & 150.43 & 0.949 & 0.949 & 0.948 & 0.951 \\
\hline $9 X-2,35$ & 157.59 & 1.085 & 1.093 & 1.092 & 1.069 \\
\hline $10 X-1,65$ & 166.25 & 1.260 & 1.263 & 1.260 & 1.258 \\
\hline $10 X-3,52$ & 169.04 & 1.067 & 1.067 & 1.067 & 1.067 \\
\hline $11 X-2,102$ & 176.71 & 1.069 & 1.083 & 1.064 & 1.060 \\
\hline $11 X-4,56$ & 179.25 & 1.180 & 1.186 & 1.177 & 1.178 \\
\hline $12 X-1,32$ & 185.12 & 0.832 & 0.832 & & \\
\hline $12 X-4,11$ & 189.16 & 1.272 & 1.282 & 1.271 & 1.264 \\
\hline $13 X-3,69$ & 197.69 & 0.718 & 0.720 & 0.716 & 0.717 \\
\hline $13 X-4,27$ & 198.27 & 1.006 & 1.000 & 1.010 & 1.008 \\
\hline $14 X-3,21$ & 206.48 & 0.287 & 0.279 & 0.294 & \\
\hline $14 X-6,11$ & 209.61 & 1.026 & 1.038 & 1.021 & 1.020 \\
\hline $15 X-2,40$ & 215.42 & 0.875 & 0.878 & 0.874 & 0.873 \\
\hline $15 X-6,31$ & 220.67 & 1.240 & 1.238 & 1.244 & 1.237 \\
\hline $16 X-4,55$ & 228.35 & 0.912 & 0.921 & 0.911 & 0.904 \\
\hline $16 X-5,51$ & 229.41 & 1.215 & 1.219 & 1.206 & 1.219 \\
\hline $17 X-3,9$ & 235.99 & 1.329 & 1.331 & 1.329 & 1.327 \\
\hline $17 X-5,56$ & 239.46 & 0.996 & 0.998 & 0.994 & 0.996 \\
\hline $19 X-1,20$ & 252.40 & 1.053 & 1.058 & 1.049 & 1.052 \\
\hline $20 X-3,62$ & 264.37 & 1.247 & 1.249 & 1.241 & 1.251 \\
\hline $20 X-5,85$ & 267.39 & 1.220 & 1.206 & 1.218 & 1.236 \\
\hline
\end{tabular}


Table T16. In situ temperature, Holes U1326C and U1326D.

\begin{tabular}{|c|c|c|c|c|c|c|c|}
\hline \multirow[b]{2}{*}{ Core } & \multirow{2}{*}{$\begin{array}{l}\text { Depth } \\
\text { (mbsf) }\end{array}$} & \multicolumn{2}{|c|}{ Temperature $\left({ }^{\circ} \mathrm{C}\right)$} & \multirow{2}{*}{$\begin{array}{l}\text { Thermal } \\
\text { conductivity } \\
(\mathrm{W} /[\mathrm{m} \cdot \mathrm{K}])\end{array}$} & \multirow{2}{*}{$\begin{array}{l}\text { Calibration } \\
\text { correction }\left({ }^{\circ}\right)\end{array}$} & \multirow{2}{*}{$\begin{array}{l}\text { Temperature } \\
\text { tool }\end{array}$} & \multirow{2}{*}{$\begin{array}{l}\text { Solution } \\
\text { reliability }\end{array}$} \\
\hline & & Corrected & Uncorrected & & & & \\
\hline $\begin{array}{l}311-U 1326 C- \\
4 \mathrm{H}\end{array}$ & 30.4 & 4.3 & 4.3 & 1.1 & 0 & APCT-3 & Very good \\
\hline \multicolumn{8}{|l|}{ 311-U1326D- } \\
\hline $19 X$ & 252 & $N A^{*}$ & NA & 1.1 & 0 & DVTP & Poor (heave) \\
\hline $21 x$ & 271.4 & NA & NA & 1.1 & 0 & DVTP & Fair (heave) \\
\hline Base of hole & 300 & NA & NA & 1.1 & 0 & DVTP & Fair (heave) \\
\hline
\end{tabular}

Notes: $\mathrm{NA}=$ not available. ${ }^{*}=$ tool did not stay in the seafloor long enough to obtain an in situ temperature reading using CONEFIT; these data will be modeled postcruise in an attempt to place an upper bound on the in situ temperature. APCT-3 = third-generation advanced piston corer temperature tool, DVTP = Davis-Villinger Temperature Probe.

Table T17. Summary of pressure coring operations at Site U1326.

\begin{tabular}{|c|c|c|c|c|c|c|c|}
\hline \multirow[b]{2}{*}{ Core } & \multirow{2}{*}{$\begin{array}{l}\text { Core-top } \\
\text { depth } \\
\text { (mbsf) }\end{array}$} & \multirow{2}{*}{$\begin{array}{l}\text { Length } \\
\text { recovered } \\
(\mathrm{cm})^{*}\end{array}$} & \multirow{2}{*}{$\begin{array}{l}\text { Length } \\
\text { curated } \\
(\mathrm{cm})\end{array}$} & \multirow{2}{*}{$\begin{array}{l}\text { Pressure at } \\
\text { core depth } \\
\quad(\mathrm{MPa})\end{array}$} & \multicolumn{2}{|c|}{$\begin{array}{c}\text { Pressure recovered } \\
(\mathrm{MPa})\end{array}$} & \multirow[b]{2}{*}{ Comments } \\
\hline & & & & & Logged $^{\dagger}$ & Gauge ${ }^{\ddagger}$ & \\
\hline \multicolumn{8}{|c|}{ 311-U1326C- } \\
\hline $11 \mathrm{Y}$ & 82.7 & 15 & 15 & 19.2 & 17.5 & 17.5 & Sand in bottom-hole assembly \\
\hline $12 \mathrm{P}$ & 83.7 & $35-40$ & 27 & 19.2 & 3.4 & 3.4 & Normal operation \\
\hline $13 \mathrm{E}$ & 85.7 & 0 & 0 & 19.2 & 0 & - & Reversal of motor unscrewed joints and left bit in hole \\
\hline
\end{tabular}

Notes: Water depth at Site U1326C is 1828 mbsl. P = Pressure Core Sampler (PCS), Y = Fugro Percussion Corer (FPC), E = HYACE Rotary Corer (HRC). ${ }^{*}=$ based on X-ray imaging and gamma ray density profiling prior to degassing. $\dagger=$ last pressure recorded before data logger disconnected from corer autoclave. Temperature $2^{\circ}-4^{\circ} \mathrm{C}$ unless otherwise noted. $\ddagger=$ pressure measured when autoclave pressure transducer connected to computer (PCS cores) or external gauge (PCS, FPC, HRC cores). Pressure measured at $7^{\circ} \mathrm{C}$ unless otherwise noted. $-=$ no data.

Table T18. In situ conditions of PCS cores recovered from Site U1326.

\begin{tabular}{|c|c|c|c|c|c|c|}
\hline \multirow[b]{2}{*}{ Core } & \multicolumn{2}{|c|}{ Depth (mbsf) } & \multirow{2}{*}{$\begin{array}{c}\text { Temperature } \\
\left({ }^{\circ} \mathrm{C}\right)\end{array}$} & \multirow{2}{*}{$\begin{array}{l}\text { Pressure } \\
(\mathrm{MPa})\end{array}$} & \multirow[b]{2}{*}{ Salinity } & \multirow{2}{*}{$\begin{array}{c}\text { Methane } \\
\text { saturation } \\
(\mathrm{mM})\end{array}$} \\
\hline & Top & Bottom & & & & \\
\hline \multicolumn{7}{|c|}{ 311-U1326C- } \\
\hline $12 \mathrm{P}$ & 83.7 & 84.7 & 8.1 & 19.2 & 32.0 & 64.0 \\
\hline
\end{tabular}

Notes: Background salinity was extrapolated from adjacent cores (Table T3). Temperature was calculated from sediment depth assuming a seafloor temperature of $3.03^{\circ} \mathrm{C}$ and a thermal gradient of $60.0^{\circ} \mathrm{C} / \mathrm{km}$. Pressure was calculated from sediment and water depth (1828 mbsl). Methane saturation was calculated based on sediment and water depth, seafloor temperature, thermal gradient, and salinity according to Xu $(2002,2004)$.

Table T19. Results from degassing experiments at Site U1326.

\begin{tabular}{|c|c|c|c|c|c|c|c|c|c|c|c|}
\hline \multirow[b]{2}{*}{ Core } & \multirow{2}{*}{$\begin{array}{l}\text { Total volume } \\
\text { of gas released } \\
(\mathrm{mL})\end{array}$} & \multirow{2}{*}{$\begin{array}{l}\text { Total volume } \\
\text { of methane } \\
\text { released }(\mathrm{mL})\end{array}$} & \multicolumn{5}{|c|}{$\begin{array}{l}\text { Average concentration } \\
\text { of released gas components (\%)* }\end{array}$} & \multirow{2}{*}{$\begin{array}{l}\text { Total volume } \\
\text { of water } \\
\text { released }(\mathrm{mL})\end{array}$} & \multirow{2}{*}{$\begin{array}{l}\text { Salinity } \\
\text { of released } \\
\text { water }\end{array}$} & \multirow{2}{*}{$\begin{array}{c}\text { Temperature } \\
\text { during } \\
\text { degassing }\left({ }^{\circ} \mathrm{C}\right)\end{array}$} & \multirow{2}{*}{$\begin{array}{c}\text { Air pressure } \\
\text { during } \\
\text { degassing } \\
(\mathrm{MPa})\end{array}$} \\
\hline & & & $C_{1}$ & $\mathrm{C}_{2}^{\dagger}$ & $\mathrm{CO}_{2}$ & $\mathrm{~N}_{2}$ & $\mathrm{C}_{1} / \mathrm{C}_{2}^{\dagger}$ & & & & \\
\hline $\begin{array}{l}\text { 311-U13 } \\
12 P\end{array}$ & 20960 & 19086 & 017 & 00054 & קח > > & 61 & 16020 & 106 & & $71+0$ & 01012 \\
\hline
\end{tabular}

Notes: * = excludes initially released gas increments that are diluted by dead volume of manifold system. $\dagger=$ subset of seven samples analyzed using methods described in "Organic geochemistry" in the "Methods" chapter. BD = below detection limit, $-=$ no data. 
Table T20. Characteristics of PCS core used for mass balance calculations, Site U1326.

\begin{tabular}{|c|c|c|c|c|c|c|c|c|}
\hline Core & $\begin{array}{l}\text { Core } \\
\text { length } \\
\text { recovered } \\
(\mathrm{m})\end{array}$ & $\begin{array}{l}\text { Sediment volume } \\
\text { in inner core } \\
\text { barrel }(\mathrm{mL})\end{array}$ & $\begin{array}{c}\text { Porosity } \\
\text { (\%) }\end{array}$ & $\begin{array}{c}\text { Pore water } \\
\text { volume in inner } \\
\text { core barrel }(\mathrm{mL})\end{array}$ & $\begin{array}{l}\text { Volume of water } \\
\text { in outer core } \\
\text { barrel }(\mathrm{mL})\end{array}$ & $\begin{array}{l}\text { Sediment extruded } \\
\text { with outer core } \\
\text { barrel water, dry } \\
\text { weight (g) }\end{array}$ & $\begin{array}{c}\text { Headspace } \\
\text { volume in outer } \\
\text { core barrel }(\mathrm{mL})\end{array}$ & $\begin{array}{l}\text { Salinity of water } \\
\text { in outer core } \\
\text { barrel }\end{array}$ \\
\hline $\begin{array}{c}311-\mathrm{U} 13 \\
12 \mathrm{P}\end{array}$ & 0.40 & 586 & 49 & 288 & 2,850 & 801 & 114 & 31.0 \\
\hline
\end{tabular}

Table T21. Mass balance calculations based on degassing experiments, Site U1326.

\begin{tabular}{|c|c|c|c|c|c|c|c|c|c|c|c|c|}
\hline \multirow[b]{3}{*}{ Core } & & & \multirow{3}{*}{$\begin{array}{l}\text { Total } C_{1} \\
\text { released } \\
\left(10^{-3} \text { mole }\right)\end{array}$} & \multirow[b]{3}{*}{ Total } & \multicolumn{4}{|c|}{$\mathrm{C}_{1}$ concentration $(\mathrm{mM})$} & \multirow{2}{*}{\multicolumn{2}{|c|}{$\begin{array}{l}\text { In situ nondissolved } \mathrm{C}_{1} \\
\text { as percentage of pore } \\
\text { volume if present as }\end{array}$}} & \multicolumn{2}{|c|}{$\begin{array}{l}\text { Potential pore water } \\
\text { freshening caused } \\
\text { by gas hydrate } \\
\text { decomposition } \\
\end{array}$} \\
\hline & \multicolumn{2}{|c|}{ Depth (mbsf) } & & & \multicolumn{2}{|c|}{ At laboratory conditions } & \multicolumn{2}{|c|}{ In situ } & & & \multirow{2}{*}{$\begin{array}{c}\text { Water } \\
\text { release }(\mathrm{mL})\end{array}$} & \multirow{2}{*}{$\begin{array}{l}\text { Freshening } \\
(\%)\end{array}$} \\
\hline & Top & Bottom & & & Dissolved* & Free $^{\dagger}$ & Dissolved ${ }^{\ddagger}$ & Nondissolved & Free gas & Gas hydrate & & \\
\hline \multicolumn{13}{|c|}{ 311-U1326C- } \\
\hline $12 \mathrm{P}$ & 83.7 & 84.7 & 855 & 2965 & 1.8 & 2963 & 64.0 & 2901 & 35 & 40 & 90 & 18 \\
\hline
\end{tabular}

Notes: * extrapolated from analysis of Sample 311-U1326C-10X-1, 145-150 cm. $\dagger=$ calculated based on the total amount of $C_{1}$ released during the degassing experiment and the pore water volume recovered by the PCS. $\ddagger=$ methane saturation from Table T18. 